\title{
Geology and Ore Deposits of the Rico District, Colorado
}

GEOLOGICAL SURVEY PROFESSIONAL PAPER 723 


\title{
Geology and Ore Deposits of the Rico District, Colorado
}

\author{
By EDWIN T. MaKNIGHT
}

GEOLOGICAL SURVEY PROFESIONAL PAPER 723

A discussion of the geology and potential of a famous old silver camp which, under modern mineral technology, became a lead, zinc, and pyrite camp

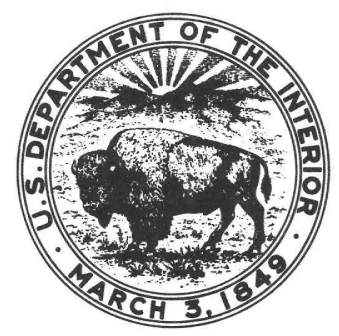

\begin{tabular}{llllll}
\hline UNITED & STATES GOVERNMENT & PRINTING OFFICE, WASHINGTON & : & 1974
\end{tabular} 


\title{
UNITED STATES DEPARTMENT OF THE INTERIOR \\ ROGERS C. B. MORTON, Secretary
}

\section{GEOLOGICAL SURVEY}

\author{
V. E. McKelvey, Director
}

Library of Congress catalog-card No. 73-600087

For sale by the Superintendent of Documents, U.S. Government Printing Office Washington, D.C. 20402 - Price $\$ 3.35$ (paper cover)

Stock Number 2401-02467 


\section{CONTENTS}

Abstract

Introduction

Location and geography of district

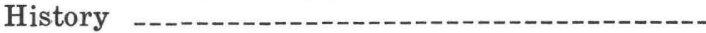

Transportation facilities

Production

Previous literature

Present investigation -.--.--

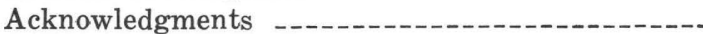

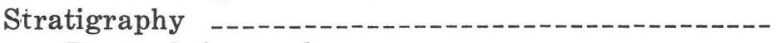

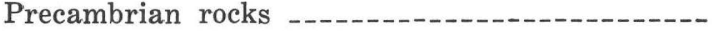

Greenstone and metadiorite -..-.-.--

Uncompahgre Quartzite -...-...-...-...

Early Paleozoic hiatus -..-.-.-_-

Devonian System --.--

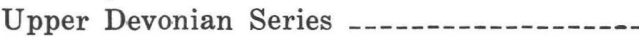
Ouray Limestone -..-.-...-

Mississippian System

Lower Mississippian Series _............. Leadville Limestone

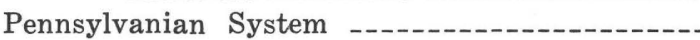

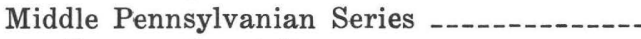
Larsen Quartzite -.................. Hermosa Formation --.-Middle and Upper(?) Pennsylvanian Series Rico Formation

Permian System -.--_-_-_-

Lower Permian Series --_-_-_-_-_-_-_Cutler Formation -

Quaternary System -..-..-

Holocene Series -.-_-_-_-_-_Surficial deposits

Igneous rocks

Hornblende latite porphyry

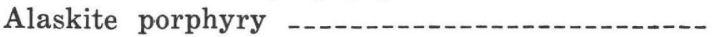

Hornblende lamprophyre -.............-.

Relations between different igneous rock types_.

Age of igneous intrusion

Igneous metamorphism -...-

Areal extent _...-_-

Mineralogy of igneous metamorphism Structure

Faults _-

Last Chance fault _...-...-

Smelter fault

Futurity fault and related fault to east -..-

Nellie Bly fault

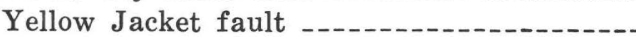

Silver Creek fault _..-_-_-_-

Faults southeast of Silver Creek bounding

the quartzite mass -

South Park fault

Knob Hill fault -...-
Structure-Continued

Faults-Continued

Sandstone Mountain fault _-_-_-_- 50

Princeton fault _-_- 50

Blackhawk fault _-_-_-_- 51

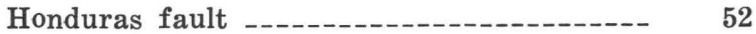

Alaskite fault _- 54

210 Drift fault -..-_- 54

Hidden fault _...- 55

Faults of Dolores Mountain and vicinity --- $\quad \mathbf{5 5}$

Faults of Deadwood Gulch _._-_- 56

Relation of structure to intrusive rocks _-_-_- $\quad 56$

Pebble dikes _..-_- 56

Ore deposits _._. 57

Mineralogy -_-_-_-_-_- 58

Hypogene minerals _._._._._._. 58

Iron oxides -.-.- 58

Sulfides -..- 58

Native gold _-

Gangue minerals -..-_-_- 62

Metamorphic minerals of, at best, only fortuitous association with ores -..--

Supergene minerals -..--_-_-_-

Paragenesis -.-.--

Types of ore deposits

Massive sulfide replacement deposits chiefly in limestones of Hermosa Formation -..--

Contact-metamorphic deposits

Veins in Hermosa sandstones and arkoses --

Replacement deposits in residual debris resulting from solution of gypsum bed -.---

Prevalence of carbon dioxide Mines

Mountain Spring-Wellington group -

Pigeon tunnel

St. Louis tunnel _.......-

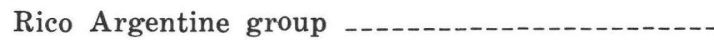

Log Cabin (Blackhawk) tunnel _......--

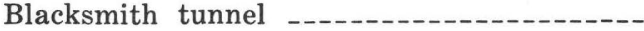

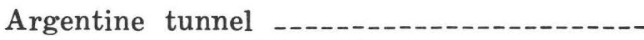

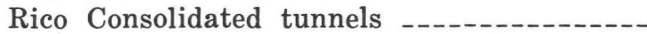

James G. Blaine tunnel _................-

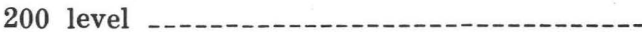

300 level -

400 level --

500 level -.-

600 level --.----_-

Yellow Jacket (Phoenix) group -...-...--

Falcon mine -......-

Aztec mine -..-..-.

Nora Lily mine -.-

Pro Patria and Revenue mines -..-.-.-.-.

Forest Payroll mine -...-..-..-

Iron Clad (Silver Clad) mine -..--

age

.

(1)

.

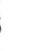

6

56
58
8
8
8
6
62


Mines-Continued

Jones gold mine

Atlantic Cable mine -...-.
Page

94

95
Suggestions for prospecting

References cited

Index
Page

95

96

99

\section{ILLUSTRATIONS}

[Plates are in pocket]

Plate 1. Geologic map and section of Rico district, Colorado.

2. Maps showing geology of Nos. 4, 5, and 6 levels of Yellow Jacket mine and some of the geology in CHC Hill, Rico district, Colorado.

3. Maps showing the geology on the Log Cabin, Argentine, Consolidated Middle, and Blaine Tunnel levels and on the 200, 300, 400, 500, and 600 levels, Rico Argentine mine, Rico district, Colorado.

Figure 1. Index map of southwestern Colorado showing location of the Rico district

Page

2. Cross section of Nellie Bly fault zone in the Rico Argentine mine

\section{TABLES}

TABLE 1. Gold, silver, copper, lead, and zinc produced in the Rico district, 1879-1968

2. Chemical compositions of metamorphic rocks from the Rico district

. Chemical compositions of igneous rocks the

3. Chemical compositions of igneous rocks from the Rico district

4. Electron-probe analysis of tetrahedrite-tennantite from Gray Copper stope, Yellow Jacket mine

5. Chemical analyses, semiquantitative spectrographic analyses, and indices of refraction of calcite from the Rico district

6. Chemical analyses, semiquantitative spectrographic analyses, and indices of refraction of dolomite from the Rico district 


\title{
GEOLOGY AND ORE DEPOSITS OF THE RICO DISTRICT, COLORADO
}

\author{
By Edwin T. McKnight
}

\begin{abstract}
The Rico district is in the Dolores River valley at the east end of Dolores County in southwestern Colorado. Mining has been actively carried on in the district since 1879. In the early days, silver was the chief product and was mined largely from Newman Hill southeast of the town of Rico. After 1900, the base metals, particularly lead and zinc, mined in other parts of the district, became the major products, though silver remained an important byproduct. The production of the Rico district from 1879 to 1968 has been about 83,000 ounces gold, $14,500,000$ ounces silver, 5,600 tons copper, 84,000 tons lead, and 83,000 tons zinc.

Bedrock in the district ranges in age from Precambrian to Permian. The older rocks are exposed in the valley of the Dolores River and its tributary, Silver Creek, near the center of a domal uplift on the east side of a monzonite stock that crops out west of the river at Rico. Precambrian rocks, which are faulted up in a horst block on the eastern prolongation of the monzonite stock, include an earlier complex of greenstone and metadiorite and the later Uncompahgre Quartzite, which is at least 1,000 feet thick. The Uncompahgre Quartzite is overlain in the subsurface by the Ouray Limestone of Devonian age; this is succeeded by the Leadville Limestone (Mississippian), which is the oldest Paleozoic formation that crops out. Combined thickness of the Ouray and Leadville is about 160 feet. Both formations have been metamorphosed by the monzonite intrusive body.
\end{abstract}

A quartzite from zero to perhaps 80 feet thick has in previous reports on the district been considered as Devonian in age and then Cambrian. Because of structural and erosional complications near the center of the dome, the sequential relations between this quartzite and the Devonian and Mississippian limestones cannot be determined from outcrops. However, drill-hole records indicate that the quartzite overlies the limestones, and fossiliferous chert pebbles found in this quartzite indicate that it cannot be older than Carboniferous. It is here assigned to basal Middle Pennsylvanian, named the Larsen Quartzite, and is considered to be the equivalent of the Molas Formation in other parts of the San Juan region.

The Hermosa Formation, of Middle Pennsylvanian age, is the most widely distributed formation in the mining district. It is about 2,800 feet thick in its best exposed section, and comprises arkoses, sandstones, shales, conglomerates, and interbedded fossiliferous limestones. Although minor limestone and dolomite are scattered through the formation, most of the limestones are concentrated in the middle third. Conglomerates are concentrated in the upper third, and the proportion of red beds increases toward the top of the formation. Lateral variation in the proportions of the different rock types is extreme, and in the southeastern part of the district, clastic strata largely disappear from the middle part of the section to produce a phase of the middle Hermosa that is thinner but is virtually all limestone. The Hermosa Formation is of great economic interest because most of the ore deposits of the district occur in it, particularly in its limestones.

The Hermosa is overlain conformably by the Rico Formation, about 300 feet thick, of Middle and probably Late Pennsylvanian age. The Rico is dominantly a sandstone and arkose sequence, in part conglomeratic, but contains other lithologic types, including limy fossiliferous sandstones in which pelecypods and gastropods are conspicuous. Many of the strata are red beds, though in general the rocks average little, if any, redder than the upper part of the Hermosa. The Rico is transitional on its lithologic and paleoecologic features between the Hermosa and Cutler Formations.

The highest formation exposed in the district is the Cutler Formation, a continental red-bed sequence of Early Permian age. Perhaps as much as 2,800 feet of strata remain, consisting of arkoses, conglomerates, sandstones, shales, and thin impure fresh-water limestones.

At the end of the Mesozoic Era the sedimentary sequence was intruded by sills and dikes of hornblende latite porphyry, one of the sills being as much as 525 feet thick. Apparently at a later stage, the ensemble was intruded by a less silicic stock of monzonite whose present outcrop, west of the Dolores River at Rico, is about 2 miles long and 1 mile wide. Other igneous types include several dikes of alaskite porphyry and a single thin dike of lamprophyre. Pervasive metamorphism of the sedimentary strata extends for 0.4 mile east from the boundary of the stock, and more channelized metamorphism extends to a maximum distance of 1.7 miles.

The dominant structure of the district is a faulted dome centered near the monzonite stock. The Rico mining district is on the northeast, east, and southeast sides of the dome. In the district the major faults near the stock trend generally east-west and border a central faulted horst block of Precambrian rock that has been uplifted at least 6,000 feet. Farther from the stock are two other major faults of diagonal trend. The Princeton fault strikes northeast through the northern part of the mining district and has its upthrow on the northwest side. The Blackhawk fault cuts from northwest to southeast diagonally across the other faults and has its upthrow on the southwest side, toward the horst block. The major faults that dominate the structural pattern of the district are normal faults, and all except the Princeton fault are of steep dip. In addition, numerous bedding faults in the Hermosa Formation have been of considerable economic importance because they commonly afforded access of ore-bearing solutions to sites favorable for ore deposition.

The ore deposits of the district consist of (1) massive sulfide replacement deposits in the limestones of the Her- 
mosa Formation; (2) contact-metamorphic deposits of sulfides and iron oxides in limestones chiefly of the Ouray and Leadville Limestones but also of the Hermosa Formation; (3) veins on fractures and small faults in Hermosa sandstones and arkoses; and (4) replacement deposits in residual debris resulting from the solution of a gypsum bed where broken by fissures in the lower Hermosa Formation.

The common sulfide minerals, present in all types of deposits, are pyrite, sphalerite, galena, and chalcopyrite. A silver-bearing mineral of the tetrahedrite-tennantite isomorphous series is widely distributed. Rarer sulfides, generally confined to certain types of deposits, include pyrrhotite, cosalite, tetradymite, and alabandite. Although no longer of significance as ore minerals, several silver minerals accounted for much of the value in the lodes (types 3 and 4 above) mined in Newman Hill before 1900. These include argentite, polybasite, proustite, pearceite, pyrargyrite, and possibly stephanite and argyrodite. Native gold is generally a minor byproduct, but, locally, it has contributed materially to the value of the ore, particularly in some of the rich silver ore formerly mined in Newman Hill.

The common gangue minerals are quartz, fluorite, calcite, dolomite, manganoan siderite, rhodochrosite, rhodonite, and sericite. Barite is of local occurrence. In the contactmetamorphic ores, specularite, magnetite, and chlorite are major gangues. Many other high-temperature silicates are only incidentally associated with the ores.

The massive sulfide replacement deposits in Hermosa limestone (type 1) have been the major source of ores in the 20 th century and account for practically all the current production. They are base-metal ores with byproduct silver and gold. Although found in the neighborhood of certain major faults such as the Blackhawk fault, the individual ore bodies are localized on minor breaks. A given ore body is centered on a fracture or minor fault and commonly involves the complete thickness of the limestone bed. Massive pyrite commonly replaces the ore bed adjacent to the feeding fracture, and sphalerite and galena, with variable, though generally sparse chalcopyrite, ring the periphery of the pyrite body. The pyritic masses yielded the sulfur for a large output of sulfuric acid for 9 years, starting in 1955 . Some of the pyrite bodies have carried enough copper locally to have been mined as argentiferous copper ores. These replacement ores have been found chiefly in two areas-in CHC Hill in the northern part of the district, and up Silver Creek, roughly $1 \frac{1}{2}$ miles east-northeast of Rico, respectively in the foot wall and hanging wall of the Princeton fault.

The contact-metamorphic deposits (type 2) are likewise base-metal ores with byproduct silver and gold. They are less extensive than type 1 , occurring only within or on the borders of the Rico townsite. They were exploited chiefly in the 1920's and again during World War II but are not now productive. The base-metal sulfides occur in irregular pods scattered through masses of specularite, magnetite, and chlorite that are centered on fracture zones of small displacement.

The vein deposits (type 3 ) are widespread in association with the replacement deposits, but are generally too thin to be economically exploitable for base-metal ores. Locally, they may be worked over short stretches where they widen or are followed by development workings. Veins of a different mineralogic type, characterized by an abundance of rich hypogene silver minerals and appreciable gold in addition to the base-metal sulfides, were worked in Newman Hill in the southern part of the district during the 1880's and 1890's but were largely exhausted by 1900 . These veins were in a northeast-trending system and were limited to a stratigraphic interval of about 150 feet, in sandstones and arkoses below a capping shaly zone in the lower Hermosa. The veins averaged only 6 inches thick, rarely reaching a thickness of 2 or 3 feet. They pinched and were impoverished in the shales. In general, vein deposits are on faults of small throw, those in Newman Hill having a displacement of less than 10 feet.

The replacement deposits in residual debris resulting from the solution of a gypsum bed (type 4) were also exhausted before 1900 . They were closely related to the rich vein deposits in Newman Hill, occurring in horizontal blanket or ribbonlike deposits overlying the apices of the veins. These so-called "contact" deposits were separated from the veins by a shaly interval, 5-20 feet thick, through which extended only minor irregular stringers of the vein material. The contact deposits were from a few inches to 6 feet thick, as much as 40 feet wide centered over the apex of the related vein, and several hundred feet long following the strike of the vein. They occurred not only over the northeasterly veins, but over northwesterly veins that were barren in the vein zone. Mineralogically, the contact deposits were similar to the productive veins, but the ore averaged considerably richer.

\section{INTRODUCTION}

\section{LOCATION AND GEOGRAPHY OF DISTRICT}

The Rico district is near the east end of Dolores County, Colo. (fig. 1), in the Rico Mountains, a subsidiary group of peaks on the southwest fringe of the San Juan Mountains. Although the peaks are high relative to the plateau country on the west and southwest, they are low relative to the San Juan Mountains. The highest point is Blackhawk Peak, at 12,677 feet, $2 \frac{1}{2}$ miles east of the town of Rico. Other peaks that more closely overlook the town, all more than 12,000 feet in altitude, are Dolores Mountain to the southeast, Telescope Mountain to the northeast, and Expectation Mountain across the river to the west. The headwaters of the Dolores River flow south through the heart of the district, and Rico is on its east bank at the confluence of Silver Creek. This creek comes from the northeast between Telescope Mountain and high spurs, including Harts Peak, that extend out from Blackhawk Peak.

The lower slopes of the Rico district are generally mantled by wash, talus, and landslide debris that has slid down from the higher hills. Alluvial fans are extensive at the mouths of the larger creeks. The general effect has been to limit the rock outcrops at lower levels, including much of the mineralized area. The outstanding exception is Sandstone Mountain, on the west side of the river, 2 miles north of Rico. Here, an extensive landslide off the west slope of Telescope Mountain has pushed the Dolores River against its west bank, so oversteepening the slope 


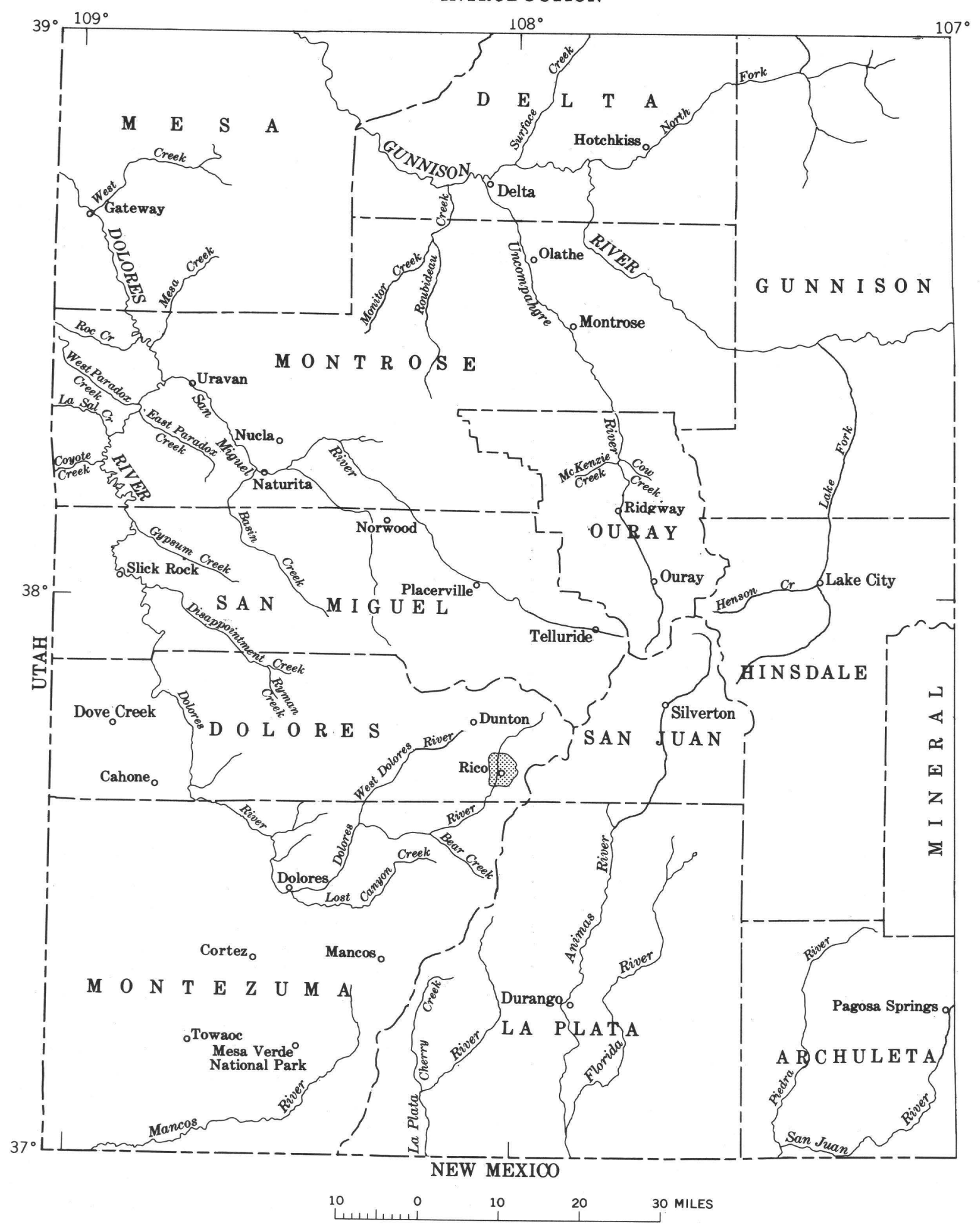

FIGURE 1.-Index map of southwestern Colorado showing location of the Rico district.

that most talus debris on that side has gone into the river and has been distributed in the alluvial material along the valley below. The resultant outcrop face on Sandstone Mountain exposes a stratigraphic section that has been of utmost importance in deciphering the geology of the district. Elsewhere in the district, indifferent outcrops yield only partial sections that can be interpreted only by reference to the Sandstone Mountain section or to underground exposures.

The hills have a discontinuous forest cover in which aspen, Colorado blue spruce, and Englemann 
spruce at higher levels are dominant types. The timberline is at about 11,500 feet.

Although some mineralized ground is on the west side of the river opposite Rico, the major production from the district has come from mines east of the river. Some of these mines have been in blocks of ground mantled by thick wash and landslide debris. Because of their importance as mining areas, some of these mantled lower slopes of the mountains have been given special names. Thus, CHC Hill is the lower west slope of Telescope Mountain, and Newman Hill is the lower west slope of Dolores Mountain. The major mineral production has come from CHC Hill; from Nigger Baby Hill, which is the long spur that extends southwest from Telescope Mountain and overlooks Rico; from the valley of Silver Creek about 11/2 miles northeast of Rico; and from Newman Hill.

In the early production of the district, silver was the major economic product; but upon depletion of the rich silver ores, lead, zinc, and, to a less extent, copper have been the main products, and silver has been an important byproduct. Gold has always been a significant byproduct, and at least one small mine has been worked exclusively for this metal. In 1955 a plant was built for production of sulfuric acid from massive pyrite ores, and in the next 9 years a substantial amount of acid was produced for use in uranium mills of the adjacent Colorado Plateau.

\section{HISTORY}

The early history of the Rico mining district has been given by Ransome (1901, p. 238-242) and therefore is only summarized here. The first claim was staked in 1869 on ground along the river at Rico, including parts of what later became the Shamrock, Smuggler, and Riverside claims. In the next 10 years, additional claims were staked within the Rico town area, on Nigger Baby Hill, in the mineralized area up Silver Creek, and in Aztec Gulch. Development work was intermittent, however, and the claims were commonly abandoned on the approach of winter.

In 1879 , oxidized silver ores were discovered on Nigger Baby Hill which were rich enough to attract a sharp influx of prospectors into the district. A mining settlement sprang up, civil government was organized, and a post office was established at Rico. In the same year, ore was discovered and shipped from one of the veins in Newman Hill. General activity in the camp increased over the next few years. In 1880 a small smelter was built on the east bank of the Dolores River at the north edge of town to treat the ores from the Grandview mine, but it proved to be short lived. A second smelter was built at the southern end of town, beginning in 1882, and operated as a custom plant for nearly 2 years during 1884-86. Silver production rose to a temporary peak of 193,360 ounces in 1883 , but it sagged appreciably in the next 3 years.

In 1887 a prospect shaft on the Enterprise claim, by pure accident, struck the edge of the largest and richest ore body ever found on Newman Hill. This was a blanket ore body of a type that proved to be very productive of rich silver ore during the next few years, as further ore bodies were explored and opened in the extension of mining from this initial discovery. The Enterprise success stimulated development throughout the camp, and within the next few years ore had been developed in all the mineralized areas that are now known, including CHC Hill. The Rio Grande Southern Railroad Co. completed a narrow-gage line into the camp in 1890 , and within a short time spur lines were operating up Silver Creek and to the portal of the Enterprise Group tunnel.

The all-time peak of silver production was reached in $1893,2,675,238$ ounces, of which the mines in Newman Hill, particularly the Enterprise mine, contributed the largest share. The drop in silver prices during the 1890 's, and particularly the famous silver panic in mid-1893, affected Rico as it did all other western mining camps, and the production fell sharply in the next few years. Yet the fundamental cause for the decline as a silver camp was depletion of the rich silver ores. By the time of the Ransome (1901) report, the Newman Hill mines were largely exhausted of all except low-grade base-metal ores.

In the early 1900 's, other parts of the district became relatively more productive, and by 1905 for the first time the combined values of lead and zinc produced in the district exceeded that of silver. Activity in the district waxed and waned with the economics of mining during the next several years, but there was substantial development and production each year. The demands for base metals before and during World War I stimulated the mining of base-metal ores, particularly in CHC Hill and in the mineralized area up Silver Creek. However, peaks of production generally depended on the fortunes of ore discovery. A temporary peak for base metals was reached in 1913 when the district produced 400 tons of copper, 1,540 tons of lead, and 1,300 tons of zinc. Although the output of lead and zinc fluctuated at a lower level in the next few years, the all-time peak production of copper, 516 tons, was reached 2 years later, principally from the Mountain SpringWellington mine of the Rico-Wellington Mining Co. 
in $\mathrm{CHC}$ Hill. Mining economic conditions began to deteriorate during the last year of the war, and production reached a low ebb by 1921 .

In the mid-1920's the mining industry at Rico revived, chiefly through advances in the metallurgical industry. Perfection of the flotation process in the previous decade had made attractive such complex sulfide ores as prevail at Rico, and the mine operators were, for the first time, able to realize a fair profit on the zinc content of their ores instead of being penalized for it as in past years. At first, the ores were shipped to new custom flotation mills in the Salt Lake area, Utah, but in 1926 a 250-ton custom mill was built at Rico by the International Smelting Co. (subsidiary of Anaconda Mining Co.), and for nearly 2 years most of the output of the district was concentrated in this mill. The chief producing companies included the Rico Argentine Mining Co., working the mineralized area up Silver Creek on the south side of the creek; the Falcon Lead Co., working the Yellow Jacket mine and other properties on Nigger Baby Hill; the Rico Mining \& Reduction Co. and (after May 1927) its successor, the St. Louis Smelting \& Refining Co., working CHC Hill, the Silver Swan mine below Rico, and a small part of the mineralized area along Silver Creek; the Pelleyre Mining \& Milling Co. (subsidiary of International Smelting Co.), working the Shamrock and several other properties in the district; Union Carbonate Mines, Inc., working the Union Carbonate mine; and the Rico Enterprise Mining Co., working the Pro Patria and Revenue mines. The all-time peak of production for base metals was made in 1927 when the district output was 5,308 tons of zinc, 4,994 tons of lead, and 65 tons of copper. The mining boom was, however, relatively short lived. The custom mill at Rico operated only from October 1926 to July 1928 , when it shut down permanently. Ore that continued to be produced for a time was shipped again to the custom mills at Salt Lake.

In 1929 mining at Rico was hit by the Depression, and by 1932, production had ceased. The St. Louis Smelting \& Refining Co. drove its St. Louis tunnel and crosscut extensions into the east bank of the Dolores River under CHC Hill during the depth of the Depression (1930-32), but failed to reach the Mississippian and Devonian limestones in which deep replacement ores were prospective targets. Mining was resumed on a relatively small scale in 1934, and production from several mines fluctuated over the next few years.

In September 1939, the Rico Argentine Mining Co. finished a new 135-ton flotation mill and began a period of steady production that brought a degree of stability to the mining industry at Rico. This company was the major producer during World War II. The Van Winkle shaft was sunk on the east edge of town in 1942, and for several years supplied a large share of the Rico Argentine production. The company has maintained steady production, though not always at mill capacity, to the present day except for two periods, May 1949 to July 1950, and June 1957 to some time in 1959, when low base-metal prices made the operation uneconomic. The long crosscut from the St. Louis tunnel to the Argentine shaft on Silver Creek was finished in 1955, lowering the water level in the Silver Creek mine workings by about 450 feet and draining a large block of mineralized ground. At present, the company controls most of the mining properties from which the major past production of the district has come. Its mill capacity (1969) is rated at 150 tons per day.

In September 1955, the Rico Argentine Mining Co. completed and put in operation a plant for the production of sulfuric acid from pyrite. The acid was sold to several uranium mills operating in the adjacent part of the Colorado Plateau. The acid plant ran for 9 years, until a cutback in the uranium program destroyed the market for the acid. The plant was put on a standby basis in October 1964 . Much of the acid production came at a period of low base-metal prices, when the entire mining facilities could readily be diverted to the mining of pyrite.

\section{TRANSPORTATION FACILITIES}

The narrow-gage railroad completed through Rico by the Rio Grande Southern Railroad Company in 1890 served the district for 60 years. In its later days, locomotive power was supplied by various models of converted automobile gasoline engines. Eventually, freight from the mining industry at Rico and Telluride was not enough to sustain the railroad, and it was finally abandoned as uneconomic in 1951. Since then, mining supplies have been brought in and concentrates taken out by truck. At present (1969), all concentrates are trucked to the Denver and Rio Grande Western Railroad line at Ridgway, Colo., where they are loaded into freight cars and shipped to the Bunker Hill Co. reduction plants at Kellogg, Idaho.

\section{PRODUCTION}

Table 1 gives the production of precious and base metals from the Rico district from 1879-1968.

Between September 1955 and October 1964, the acid plant produced 316,108 tons of commercial sulfuric acid, 100 percent basis. In the first year and a quarter, pyritic tailings from the lead-zinc mill 
TABLE 1.-Gold, silver, copper, lead, and zinc produced in the Rico district, 1879-1968

[Figures derived by subtracting from the production of Dolores County that of the Lone Cone district, which is the only other metal-producing district of record (1896-1941) in the county. Lone Cone production for 1896-1903 estimated (gold and silver only), for later years from unpublished statistical charts furnished by the U.S. Bur. Mines. Production of Dolores County for 1879-1923 from Henderson (1926, p. 117); for Minerals Yearbook; for 1963-68, from unpublished statistics furnished by U.S. Bur. Mines. Compilation for Dolores County by Robert G. Luedke, U.S. Geol. Survey]

\begin{tabular}{|c|c|c|c|c|c|c|c|c|c|c|c|}
\hline & & & gold & & & & opper & & end & & Zine \\
\hline Year & & $\begin{array}{c}\text { Fine } \\
\text { ounces }\end{array}$ & Value & $\begin{array}{c}\text { Fine } \\
\text { ounces }\end{array}$ & Value & $\begin{array}{c}\text { Short } \\
\text { tons }\end{array}$ & Value & $\begin{array}{l}\text { Short } \\
\text { tons }\end{array}$ & Value & $\begin{array}{l}\text { Short } \\
\text { tons }\end{array}$ & Value \\
\hline 1879 & - - - & 73 & $\$ 1,500$ & 7,734 & $\$ 8,662$ & 2 & $\$ 800$ & 5 & $\$ 410$ & --- & ---- \\
\hline 1880 & - & 169 & 3,500 & 30,938 & 35,579 & 14 & 6,206 & 50 & 5,000 & -- & -- \\
\hline $\begin{array}{l}1881 \\
1882\end{array}$ & - - & 242 & $\begin{array}{r}5,000 \\
\end{array}$ & 69,610 & 78,659 & 22 & 8,008 & 100 & 9,600 & ---- & $--\cdot$ \\
\hline $\begin{array}{l}1882 \\
1883\end{array}$ & - & $\begin{array}{l}484 \\
242\end{array}$ & 10,000 & 85,078 & 96,989 & 27 & 10,314 & 100 & 9,800 & --- & $\cdots$ \\
\hline $\begin{array}{l}1883 \\
1884\end{array}$ & - & $\begin{array}{r}242 \\
73\end{array}$ & $\begin{array}{l}5,000 \\
1,500\end{array}$ & $\begin{array}{l}193,360 \\
54,141\end{array}$ & 214,630 & 50 & 16,500 & 100 & 8,600 & --- & --- \\
\hline 1885 & - & $\begin{array}{l}190 \\
193\end{array}$ & 4,000 & $\begin{array}{l}54,141 \\
70,000\end{array}$ & $\begin{array}{l}60,097 \\
74,900\end{array}$ & -- & ---- & $\begin{array}{l}76 \\
50\end{array}$ & $\begin{array}{l}5,624 \\
3,900\end{array}$ & --- & --- \\
\hline 1886 & ---- & 414 & 8,561 & 75,836 & 75,078 & 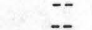 & -..- & 396 & $\begin{array}{l}0,432 \\
\mathbf{3 6 , 4 3 2}\end{array}$ & $-\cdots$ & $-\cdots$ \\
\hline 1887 & -..--..-- & 471 & 9,743 & 118,262 & 115,897 & $\overline{17}$ & $4, \overline{692}$ & 500 & 45,000 & --- & --- \\
\hline 1888 & - & 845 & 17,470 & 123,852 & 116,421 & $\ldots$ &.-- & 500 & 44,000 & --- & --- \\
\hline $\begin{array}{l}1889 \\
1890\end{array}$ & ----- & $\begin{array}{l}3,765 \\
7561\end{array}$ & $\begin{array}{r}77,825 \\
\end{array}$ & 618,615 & 581,498 & -- & $-\cdots$ & 1,000 & 78,000 &.--- & ---- \\
\hline $\begin{array}{l}1890 \\
1891\end{array}$ & - & $\begin{array}{l}7,561 \\
5,932\end{array}$ & 156,297 & $\begin{array}{l}848,785 \\
699888\end{array}$ & 891,224 & -- & $--\cdot-$ & 1,000 & 90,000 & --- & --- \\
\hline $\begin{array}{l}1892 \\
\end{array}$ & (n) & $\begin{array}{r}5,352 \\
11,401\end{array}$ & $\begin{array}{l}12,6351 \\
235669\end{array}$ & $\begin{array}{r}699,888 \\
1\end{array}$ & $\begin{array}{r}692,889 \\
\end{array}$ & -- & & $\begin{array}{r}466 \\
1512\end{array}$ & $\begin{array}{r}40,047 \\
123,327\end{array}$ & $\cdots$ & --- \\
\hline 1893 & $-0-$ & 21,387 & 442,105 & $2,675,238$ & $\begin{array}{r}1,118,106 \\
20866686\end{array}$ & 7 & $\begin{array}{l}1,513 \\
1,080\end{array}$ & $\begin{array}{l}1,542 \\
2,250\end{array}$ & $\begin{array}{l}123,327 \\
166,500\end{array}$ & --- & --- \\
\hline 1894 & ----- & 9,318 & 192,626 & $1,153,325$ & $\begin{array}{r}2,000,000 \\
726,595\end{array}$ & $\begin{array}{r}0 \\
15\end{array}$ & 2,850 & $\begin{array}{l}2,200 \\
1,000\end{array}$ & $\begin{array}{r}16,000 \\
66,000\end{array}$ & $\cdots$ & $\cdots$ \\
\hline 1895 & $-\cdot-$ & 2,542 & 52,552 & 399,283 & 259,534 & 32 & 6,864 & 157 & 10,042 & $-\cdots$ & $\cdots$ \\
\hline 1896 & - & 216 & 4,465 & 221,393 & 150,547 & & & 550 & 33,000 & 15 & $\$ 1,170$ \\
\hline 1897 & - & $\begin{array}{r}603 \\
\end{array}$ & 12,464 & 104,901 & 62,941 & 20 & 4,758 & 547 & 39,378 & & \\
\hline $\begin{array}{l}1898 \\
1899\end{array}$ & - & 1,771 & $\begin{array}{l}36,607 \\
05\end{array}$ & 338,346 & 199,624 & 75 & 18,556 & 343 & 26,091 & 200 & 18,400 \\
\hline $\begin{array}{l}1899 \\
1900\end{array}$ & - & 1,234 & 25,508 & $\begin{array}{l}157,052 \\
\end{array}$ & 94,231 & 22 & 7,611 & 1,023 & 92,080 & 50 & 5,800 \\
\hline 1901 & - & $\begin{array}{l}925 \\
179\end{array}$ & $\begin{array}{r}19,120 \\
3,700\end{array}$ & $\begin{array}{l}84,318 \\
66632\end{array}$ & $\begin{array}{l}52,227 \\
39979\end{array}$ & 18 & $\begin{array}{l}5,978 \\
2189\end{array}$ & $\begin{array}{l}105 \\
184\end{array}$ & $\begin{array}{r}9,257 \\
915733\end{array}$ & 110 & $\begin{array}{r}9,680 \\
10250\end{array}$ \\
\hline 1902 & ------ & 296 & 6,118 & $\begin{array}{l}66,632 \\
46,311\end{array}$ & $\begin{array}{l}39,979 \\
24,545\end{array}$ & $\begin{array}{l}7 \\
8\end{array}$ & $\begin{array}{l}2,189 \\
1,837\end{array}$ & $\begin{array}{l}184 \\
194\end{array}$ & $\begin{array}{l}15,783 \\
15,941\end{array}$ & $\begin{array}{l}125 \\
124\end{array}$ & $\begin{array}{l}10,250 \\
11,937\end{array}$ \\
\hline 1903 & - & 293 & $\begin{array}{r}6,056 \\
.\end{array}$ & 45,096 & 24,352 & 74 & 20,220 & 72 & 6,024 & & \\
\hline 1904 & - & 657 & 13,578 & 44,432 & 26,251 & 13 & 3,250 & 91 & 7,793 & 9 & 928 \\
\hline $\begin{array}{l}1905 \\
1906\end{array}$ & ----.-- & $\begin{array}{l}206 \\
455\end{array}$ & $\begin{array}{l}4,250 \\
9398\end{array}$ & 29,496 & 18,275 & 60 & 18,692 & 420 & 39,495 & 278 & 32,820 \\
\hline $\begin{array}{l}1906 \\
1907\end{array}$ & - & $\begin{array}{l}455 \\
132\end{array}$ & $\begin{array}{r}9,398 \\
2734\end{array}$ & $\begin{array}{r}34,290 \\
202317\end{array}$ & 23,317 & 100 & $\begin{array}{l}38,480 \\
10,000\end{array}$ & $\begin{array}{l}59 \\
97\end{array}$ & $\begin{array}{l}6,739 \\
28901\end{array}$ & 442 & 53,896 \\
\hline 1908 & 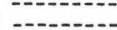 & $\begin{array}{l}132 \\
588\end{array}$ & 12,155 & $\begin{array}{l}20,317 \\
85,310\end{array}$ & $\begin{array}{l}13,409 \\
45,214\end{array}$ & $\begin{array}{l}50 \\
21\end{array}$ & $\begin{array}{l}19,899 \\
5,488\end{array}$ & 27 & $\begin{array}{r}2,891 \\
39772\end{array}$ & -255 & 23.932 \\
\hline 1909 & - & 514 & 10,641 & 64,375 & $\begin{array}{l}\begin{array}{l}40,214 \\
33,475\end{array} \\
3\end{array}$ & 22 & $\begin{array}{l}0,488 \\
5,621\end{array}$ & $\begin{array}{l}474 \\
230\end{array}$ & $\begin{array}{l}39,722 \\
19,756\end{array}$ & 84 & $\begin{array}{r}20,704 \\
9,049\end{array}$ \\
\hline 1910 & - & 320 & 6,616 & 49,795 & 26,889 & 48 & 12,113 & $\begin{array}{r}200 \\
62\end{array}$ & $\begin{array}{r}5,479 \\
5,10\end{array}$ & 44 & 4,698 \\
\hline 1911 & - - & 23 & 475 & 30,842 & 16,346 & 2 & 373 & & $\begin{array}{l}3,476 \\
31,476\end{array}$ & 263 & 29,944 \\
\hline 1912 & -1 & 64 & 1,313 & 68,794 & 42,309 & 345 & 113,709 & $\begin{array}{l}500 \\
604\end{array}$ & 54,339 & 406 & 56,030 \\
\hline 1913 & - & 306 & 6,333 & 153,111 & 92,479 & 400 & 124,057 & 1,538 & & 1,298 & 145,389 \\
\hline 1914 & $--1-$ & 317 & 6,542 & & 44,707 & 175 & 46,576 & $\begin{array}{r}1,000 \\
246\end{array}$ & 19,156 & 183 & 18,694 \\
\hline 1915 & --- & 524 & 10,828 & $\begin{array}{r}122,664 \\
\end{array}$ & 62,190 & 516 & 180,670 & 134 & 12,593 & 18 & 4,456 \\
\hline 1916 & - & 269 & 5,557 & 71,578 & 47,098 & 210 & 103,197 & 294 & 40,551 & 91 & 24,429 \\
\hline 1917 & - - & 252 & 5,213 & 88,222 & 72,695 & 260 & 141,937 & 886 & 152,411 & 851 & 173,538 \\
\hline 1918 & $-\infty$ & 145 & 2,991 & 54,240 & 54,240 & 309 & 152,649 & 259 & 36,735 & 331 & 60,174 \\
\hline 1919 & - - - & 122 & 2,517 & 35,084 & 39,294 & 132 & 49,284 & 49 & 5,231 & 34 & $\begin{array}{r}4,893 \\
\end{array}$ \\
\hline 1920 & $\cdots$ & 85 & 1,759 & 28,556 & 31,126 & 3 & 1,252 & 386 & 61,752 & 115 & 18,619 \\
\hline $\begin{array}{l}1921 \\
1922\end{array}$ & 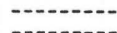 & $\begin{array}{l}68 \\
54\end{array}$ & 1,401 & 10,524 & 10,524 & 1 & 96 & 9 & 838 & $-\cdots$ & -..- \\
\hline 1923 & 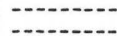 & $\begin{array}{l}54 \\
56\end{array}$ & $\begin{array}{l}1,126 \\
1,154\end{array}$ & $\begin{array}{l}25,423 \\
333471\end{array}$ & $\begin{array}{l}25,423 \\
27,447\end{array}$ & 12 & $\begin{array}{l}3,252 \\
8336\end{array}$ & $\begin{array}{l}44 \\
81\end{array}$ & $\begin{array}{r}4,796 \\
11,31\end{array}$ & & $9-\overline{384}$ \\
\hline 1924 & 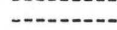 & $\begin{array}{r}56 \\
8\end{array}$ & $\begin{array}{r}1,154 \\
178\end{array}$ & $\begin{array}{r}33,471 \\
8,709\end{array}$ & $\begin{array}{r}27,447 \\
5,835\end{array}$ & 28 & $\begin{array}{l}8,336 \\
1,545\end{array}$ & $\begin{array}{l}81 \\
89\end{array}$ & $\begin{array}{l}11,331 \\
14167\end{array}$ & $\begin{array}{l}69 \\
11\end{array}$ & $\begin{array}{l}9,384 \\
1,417\end{array}$ \\
\hline 1925 & - - & 83 & $\begin{array}{r}1,722 \\
\end{array}$ & 37,994 & $\begin{array}{r}5,850 \\
26,368\end{array}$ & $\begin{array}{r}6 \\
23\end{array}$ & $\begin{array}{l}1,54 b \\
6,674\end{array}$ & $\begin{array}{r}89 \\
908\end{array}$ & $\begin{array}{r}14,167 \\
157,975\end{array}$ & 1,053 & 160,056 \\
\hline 1926 & - & 189 & 3,902 & 92,040 & 57,433 & 54 & 15,036 & 2,917 & 466,760 & 2,981 & 447,150 \\
\hline 1927 & $--1-1$ & 411 & 8,488 & 173,395 & 98,315 & 65 & 17,161 & 4,994 & & 5,308 & 679,360 \\
\hline 1928 & ------- & 1,044 & 21,585 & 350,653 & 205,132 & 444 & 127,730 & 4,526 & 524,964 & 4,646 & 566,812 \\
\hline 1929 & .......... & 532 & 11,016 & 268,783 & 143,261 & 164 & 57,596 & 3,530 & 444,739 & 2952 & 389,730 \\
\hline 1930 & - & 386 & 7,975 & 80,683 & $\begin{array}{r}140,201 \\
31,063\end{array}$ & $\begin{array}{l}104 \\
155\end{array}$ & 40,170 & 678 & 67,750 & 595 & 57,120 \\
\hline 1931 & - & 34 & 697 & 1,648 & 478 & 1 & 182 & 35 & 2,553 & 41 & 3,116 \\
\hline 1932 & - & 5 & 95 & & 1 & & & & & & \\
\hline 1933 & - & 40 & 817 & 4,820 & 1,687 & 1 & 51 & 3 & 222 & --- & \\
\hline 1934 & - & 352 & 12,287 & 49,302 & 31,872 & 10 & 1,584 & 119 & 8,843 & 107 & $\begin{array}{r}9,202 \\
, 250\end{array}$ \\
\hline $\begin{array}{l}1935 \\
1936\end{array}$ & 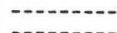 & $\begin{array}{r}656 \\
309\end{array}$ & $\begin{array}{l}22,944 \\
10801\end{array}$ & 71,040 & 51,060 & 13 & 2,075 & 140 & 11,220 & 142 & 12,452 \\
\hline $\begin{array}{l}1936 \\
1937\end{array}$ & -....... & 309 & 10,801 & 20,031 & 15,514 & 7 & 1,288 & 119 & 10,948 & 139 & 13,950 \\
\hline 1937 & 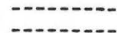 & 188 & 6,566 & 13,086 & 10,122 & 7 & 1,694 & 125 & 14,697 & 136 & 17,680 \\
\hline 1938 & & 34 & 1,200 & 4,642 & 3,001 & 2 & 333 & 29 & 2,622 & 30 & 2,880 \\
\hline 1939 & - & 121 & 4,235 & 41,356 & 28,072 & 65 & 13,416 & 752 & 70,688 & 867 & 90,168 \\
\hline 1940 & - & 275 & 9,625 & 153,990 & 109,504 & 482 & 109,045 & 1,928 & 192,750 & 2,607 & 328,482 \\
\hline 1941 & 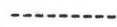 & 102 & 3,570 & 112,715 & 80,153 & 62 & 14,632 & 2,525 & 287,833 & 3,004 & 450,600 \\
\hline 1942 & - & 119 & 4,165 & 110,918 & $\begin{array}{r}78,875 \\
\end{array}$ & 35 & $\begin{array}{r}8,482 \\
18785\end{array}$ & 2,282 & 305,795 & 2,764 & 514,178 \\
\hline 1943 & - n & 127 & 4,445 & 145,021 & 103,126 & 72 & 18,785 & 2,566 & 384,900 & 3,652 & 788,832 \\
\hline 1944 & - & 141 & 4,935 & 121,791 & 86,607 & 118 & 31,995 & 2,826 & 452,240 & 4,557 & $1,038,996$ \\
\hline 1945 & -1 & 157 & 5,495 & 152,266 & 108,278 & 86 & 23,220 & 2,440 & 419,680 & 3,920 & 901,600 \\
\hline 1946 & - & 136 & 4,760 & 173,297 & 140,024 & 112 & 36,126 & 2,176 & 474,259 & 3,435 & 838,140 \\
\hline 1947 & 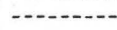 & 104 & 3,640 & 124,199 & 112,400 & 109 & 45,591 & 2,042 & 588,168 & 3,433 & 830,883 \\
\hline 1948 & - & 108 & 3,780 & 132,312 & 119,749 & 74 & 32,116 & 2,430 & 869,940 & 3,180 & 845,880 \\
\hline 1949 & - & $\begin{array}{l}79 \\
711\end{array}$ & 2,765 & 80,032 & 72,433 & 33 & 13,002 & 1,388 & 438,608 & 1,354 & 335,792 \\
\hline 1950 & - - & 71 & 2,485 & 72,735 & 65,829 & 35 & 14,560 & 1,138 & 307,260 & 1,365 & 387,660 \\
\hline 1951 & 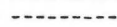 & 220 & 7,700 & 131,912 & 119,387 & 51 & 24,684 & 2,231 & 771,926 & 2,527 & 919,828 \\
\hline 1952 & - & 128 & 4,480 & 127,446 & 115,345 & 73 & 35,332 & 2,230 & 718,060 & $\overrightarrow{2}, 734$ & 907,688 \\
\hline 1953 & - & 95 & 3,325 & 103,908 & 94,042 & 18 & 10,332 & 1,871 & 490,202 & 2,634 & 605,820 \\
\hline 1954 & - & 147 & 5,145 & 118,621 & 107,358 & 11 & 6,490 & 2,177 & 596,498 & 2,896 & 625,536 \\
\hline 1955 & - & 156 & 5,460 & 114,392 & 103,531 & 5 & 3,730 & 2,202 & 656,196 & 2,571 & 632,466 \\
\hline 1956 & - & 179 & 6,265 & 97,181 & 87,954 & 6 & 5,270 & 1,858 & 583,396 & 1,668 & 457,114 \\
\hline $\begin{array}{l}1957 \\
1958\end{array}$ & - & 13 & 455 & 8,829 & 7,991 & 1 & 181 & 201 & 57,515 & 159 & 36,958 \\
\hline 1959 & (-n) & 18 & 630 & 17,562 & $15,89 \overline{4}$ & $-\overline{3}$ & 1,750 & 325 & 74,865 & 362 & 83,214 \\
\hline 1960 & & 84 & 2,940 & 81,593 & 73,846 & 10 & 6,388 & 1,377 & 322,183 & 961 & 248,041 \\
\hline 1961 & - & 63 & 2,205 & 49,091 & 45,384 & 7 & 4,290 & 833 & 171,444 & 94 & 217,695 \\
\hline 1962 & - & 46 & 1,610 & 81,5 & 34,202 & 5 & 2,895 & 782 & 143,952 & 681 & 156,722 \\
\hline 1963 & - & 25 & 875 & 30,112 & 38,517 & 5 & 3,326 & 542 & 117,050 & 484 & 111,320 \\
\hline 1964 & - & 22 & $\begin{array}{r}770 \\
0\end{array}$ & 21,939 & 28,367 & 3 & 2,184 & 484 & 126,677 & 498 & 135,443 \\
\hline 1965 & -......... & 68 & 2,380 & 74,129 & 95,849 & 18 & 12,850 & 1,457 & 454,521 & 1,456 & 425,137 \\
\hline & - & 68 & 2,380 & 54,533 & 70,511 & 26 & 18,664 & 1,109 & 335,220 & 1,147 & 332,674 \\
\hline 1967 & - & 57 & 1,995 & 71,387 & 110,650 & 20 & 15,176 & 1,449 & 405,804 & 1,708 & 472,849 \\
\hline 1968 & - & 59 & 2,316 & 77,129 & 165,411 & 18 & 15,023 & 1,461 & 386,028 & 1,610 & 434,808 \\
\hline & Total .. & 83,045 & $1,781,702$ & $14,513,288$ & $11,735,029$ & 5,637 & $1,951,561$ & 83,847 & $15,228,650$ & 82,717 & $17,243,559$ \\
\hline
\end{tabular}


furnished the feed for the plant; these tailings had to be upgraded by milling in order to attain the 45-50 percent sulfur necessary for economic operation of the acid plant. After exhaustion of suitable tailings, massive pyrite was mined for the feed, chiefly from the mines of CHC Hill. The total of "ore" for the acid plant amounted to about 297,700 tons of mined pyrite and an estimated 80,000 tons of tailings.

\section{PREVIOUS LITERATURE}

Most of the geologic literature on the Rico district was published near the turn of the century when the camp had just finished a period of major silver production and before its potential as a producer of base metals was realized. Papers were published on the ore deposits of Newman Hill by Farish (1892) and on the Enterprise mine by Rickard (1897), both of whom, according to Ransome (1901, p. 308), had been in charge of development at the Enterprise mine at different times. Both of these early papers devote much attention to the geometry of the ore deposits in Newman Hill, including the details of vein structure, the relation between the northeasterly and northwesterly vein systems, and their relation to the bedded or "contact" ore capping the veins at a certain stratigraphic horizon.

The general stratigraphy, structure, and igneous petrology of the whole district was first worked out by Cross and Spencer (1900), who published an excellent geologic map with their report. They described two lithologic phases of the "Devonian," a limestone and a quartzite, and believed that the quartzite underlay the limestone. However, they declined to name Devonian formations in such an area of limited and fragmented outcrops.

Ransome's (1901) report on the ore deposits of the district supplemented the Cross and Spencer report. It gave a very complete account of the mineral deposits, including descriptions of minor prospects as well as the major ore deposits that had been opened to that time. Although his report gave much information on Newman Hill based on original observations, it also relied heavily on the reports of Farish and Rickard for information that was no longer available because of stope caving, particularly in the "contact" ore.

The geologic atlas of the Rico quadrangle by Cross and Ransome (1905) included, as a special economic geology map, the earlier map by Cross and Spencer (1900). In addition to the refinements expected in a finished product, the "Devonian" unit of the earlier publication was divided into two formations, the Ouray Limestone and the Ignacio
Quartzite, the latter designated as Cambrian in age. Correlation of the quartzite was by analogy with the geologic section a few miles farther east where geologic work had, in the interim, demonstrated the presence of a Cambrian quartzite.

In 1913, Bastin collected ore specimens from certain mines and mine dumps in Newman Hill for a study of silver enrichment in the San Juan Mountain region. The results were published in 1922 . He described the relations of several silver-bearing minerals to other commoner minerals occurring in the specimens and concluded that most of the silver minerals were of hypogene origin.

During World War II, D. J. Varnes spent 21/2 months mapping in a part of the Rico district as part of a war program for aiding prospecting in promising base-metal districts. His attention was confined largely to the areas near the town of Rico that are underlain by the Mississippian and Devonian limestones. His preliminary maps with a short explanatory text issued in 1944 have been available to the author in preparing this more complete report on the Rico district.

The Rico district is included in the compendium on the geology and petrology of the San Juan region, authored by Larson and Cross in 1956. Although the information on Rico is all taken from the earlier reports on the district, integration of information on the larger area throws some light on the Rico district in its broader regional setting.

\section{PRESENT INVESTIGATION}

The author began fieldwork in the Rico district in the late spring of 1930 , and was assisted by Cornelius S. Hurlbut, Jr. At the beginning of the project, B. S. Butler spent several days with the field party, visiting several of the mines and outlining the goals of the project. Fieldwork was discontinued in the fall, but resumed the following summer when Edwin B. Eckel was the assistant. After the 1931 field season, the project was recessed owing to lack of funds during the depression, and the author was assigned to other projects.

World War II, the Korean War, and the assignment of the author to successive projects of higher priority, delayed any further work at Rico until 1955. In the four summers of 1955-58, the fieldwork in the district was completed. This included geologic mapping of the area covered by the mining district topographic map which was prepared by C. A. Ecklund in 1930, and underground mapping of all mines that were accessible during the fieldwork. John G. Stone was the field assistant in 1955; James C. Ratté and David A. Brew, in 1956; James Marlow, 
in 1957; and Robert C. Pearson, in 1958.

In July and early August 1967, the author spent 5 weeks in the district checking certain field items and examining some of the later underground workings.

\section{ACKNOWLEDGMENTS}

The author is indebted to the several assistants mentioned, to whose energy and cooperation the successful completion of the field work is due. Personnel of the mining companies have been uniformly cooperative in furnishing information and maps, and in permitting access to the mines. Especial thanks are due to Duane M. Kline, superintendent for the St. Louis Smelting \& Refining Co. in the 1930 's ; the late Robert L. Pellet, general manager of the Falcon Lead Co. in the early 1930's; Mrs. Elizabeth Pellet, for matters pertaining to the Falcon Lead Co.; Sherman B. Hinckley, president and general manager, and Orval L. Jahnke, superintendent of the Rico Argentine Mining Co.; Mrs. Helen Hicks, for matters pertaining to the Aztec and Forest Payroll mines; and Myron Jones, for matter pertaining to the Iron Clad and Jones mines.

\section{STRATIGRAPHY}

Erosion of domed strata on the east side of a monzonite stock at Rico has revealed formations ranging in age from Precambrian to Permian (pl. 1).

The Precambrian rocks are present only in upthrust fault blocks of a small area at the center of the dome. Two classes of rocks are represented-an earlier complex of intimately associated greenstone and metadiorite, and a later quartzite. At the surface, these two classes of rocks are in contact with later formations only along faults.

The oldest Paleozoic formation exposed is the Leadville Limestone of Mississippian age, but this is probably underlain in the subsurface by the Ouray Limestone of Devonian age. Deep drill holes show that the Ouray overlies a quartzite which is believed to be the Precambrian quartzite exposed in the upthrust blocks at the center of the dome. If this interpretation is correct, the early Paleozoic hiatus is somewhat greater at Rico than at other places in the San Juan region, where an earlier Devonian formation and a Cambrian quartzite (Ignacio) occupy the interval between the Ouray and the Precambrian.

The Leadville Limestone is overlain unconformably by the Larsen Quartzite, a Pennsylvanian formation of local distribution, herein named for outcrops in the Rico district. The next overlying unit, also of Pennsylvanian age, is the Hermosa Formation, which is the most widely distributed formation in the district. It is a thick series of arkosic sandstones, shales, conglomerates, and interbedded limestones, of great economic interest because most of the ore deposits of the district have been confined to it and particularly to its limestones.

The Hermosa is overlain by the Rico Formation, a relatively thin transitional unit between the gray marine strata below and the continental red beds of the thick Cutler Formation, of Permian age, above. The Cutler, or igneous sills intrusive into it, caps the mountain peaks surrounding the district.

\section{PRECAMBRIAN ROCKS \\ GREENSTONE AND METADIORITE}

The rocks believed to be the oldest in the Rico district are in an east-west belt that crosses the river north of the town of Rico. These rocks are in an upthrusted fault block about half a mile long and a maximum of 1,000 feet wide. The dominant rock type is a dark-greenish-gray fine-grained greenstone that is for the most part only poorly foliated. There are large masses in which no foliation is discernible, but, locally, enough foliation is present to class the rock as a phyllite. Where developed, the foliation strikes generally between northwest and west, and dips south at $60^{\circ}-90^{\circ}$. The greenstone contains lenses and thick pods of nearly black metadiorite, ranging in texture from coarse to fine grained. On the west side of the river, the largest metadiorite pods trend northwest or north and dip vertically. One zone of closely spaced pods is $100-200$ feet wide and at least 700 feet long. The field relations suggest that the metadiorite was derived from an igneous rock originally intrusive into the greenstone. The contact, however, is indefinite and gradational at the few places where it has been seen.

Table 2 gives chemical analyses of typical samples of the greenstone and metadiorite made in the laboratories of the U.S. Geological Survey.

GREENSTONE

Mineral composition of the greenstone is determinable only in thin section. Quartz grains are present in all sections and also fine clear equant grains of sodic plagioclase which are untwinned and optically indistinguishable from the finer grained quartz. An X-ray investigation of the analyzed sample (table 2), made by David B. Stewart, indicates that the plagioclase is sodic andesine $\left(\mathrm{An}_{32 \pm 2}\right)$ and that it makes up roughly 30-40 percent of the rock in comparison with roughly 10-15 percent for the quartz. Other constituents vary from place to place. In an unfoliated phase, fine pale-bluegreen hornblende ( $n \mathrm{Z}$ about $1.67, \mathrm{Z}$ to $c$ about $22^{\circ}$ ) in individual needles and tufts is the next most 
TABLE 2.-Chemical compositions, in percent, of metamorphic rocks from the Rico district, Colorado

[Analyses by standardized rapid methods]

\begin{tabular}{|c|c|c|}
\hline & 1 & 2 \\
\hline $\begin{array}{l}\mathrm{SiO}_{2} \\
\mathrm{TiO}_{2} \\
\mathrm{Al}_{2} \mathrm{O}_{3} \\
\mathrm{Fe}_{2} \mathrm{O}_{3} \\
\mathrm{FeO} \\
\mathrm{MnO} \\
\mathrm{Mg} \mathrm{O} \\
\mathrm{CaO} \\
\mathrm{Na}_{2} \mathrm{O} \\
\mathrm{K}_{2} \mathrm{O} \\
\mathrm{H}_{2} \mathrm{O} \\
\mathrm{H}_{2} \mathrm{O}\end{array}$ & $\begin{array}{l}57.4 \\
.69 \\
16.8 \\
3.9 \\
3.6 \\
.19 \\
3.5 \\
7.1 \\
4.7 \\
.33 \\
.00 \\
1.3 \\
.13 \\
<.05 \\
.03\end{array}$ & $\begin{array}{l}54.6 \\
.81 \\
13.7 \\
3.0 \\
7.5 \\
.25 \\
6.3 \\
7.4 \\
2.4 \\
1.8 \\
.00 \\
1.8 \\
.22 \\
.05 \\
.08\end{array}$ \\
\hline Total (to nearest unit) & 100 & 100 \\
\hline
\end{tabular}

1. Unfoliated greenstone, from upper side of road leading from St. Louis 2. Tunnel to Rico Argentine mill, $375 \mathrm{ft}$ south of Last Chance fault. southwest from dump of prospect hole $10 \mathrm{ft}$ deep, $10 \mathrm{ft}$ from Wonder mine portal.

abundant mineral after the feldspar and quartz. It shows an ill-defined lineation in one unoriented thin section in that alinement of the needles falls mostly within a $90^{\circ}$ arc and avoids the quadrant at right angle. A phyllitic phase of the greenstone contains no hornblende but abundant muscovite and some biotite, both tending to show prism faces terminating the ends of the cross sections. Chlorite and fine grains of epidote are common, and in the unfoliated phase the chlorite may locally replace hornblende needles pseudomorphously. Some of the epidote grains have gradational segments of allanite. Accessory minerals include sphene in anhedral grains, apatite in small stout prisms or more rounded grains, magnetite in anhedral grains that may show crystal faces in a few places, and rare zircon in small prisms. Veinlets of epidote or mixed epidote, chlorite, and quartz in the greenstone may be related to the later igneous metamorphism superposed on the earlier metamorphic rock.

The presence of relict green hornblende and feldspar in some specimens of the unfoliated rock suggests that the greenstone was derived from an igneous rock. Both of these minerals are in very irregular grains. The hornblende relicts are cracked along the cleavage into several segments that have remained in contact despite extensive corrosion at the sides and jagged ends. The feldspar may be spotted poikilitically by quartz or embayed by mosaics of quartz grains and is, in general, heavily clouded with sericite or claylike inclusions that obscure mineral determination. Some of it has a perthitic mottling and is untwinned, suggesting ortho- clase; other grains show the plagioclase twinning. The analysis (table 2) of a typical sample of the unfoliated greenstone suggests an igneous rock of about the composition of diorite or andesite (Johannsen, 1937, p. 155-156; see also Nockolds, 1954, p. 1018-1019).

Rock specimens from the dump of the Futurity mine contain abundant megascopic grains of feldspar in a fine-grained dark-gray matrix; in general appearance they resemble a slightly deformed igneous rock. Microscopic examination shows that the feldspar is relatively fresh albite which occurs as irregularly rounded, oval, or lath-shaped grains as much as $21 / 2 \mathrm{~mm}$ long. The grain boundaries are very ragged in detail against the interstitial groundmass which is the hornblendic phase of the greenstone. X-ray investigation by Stewart shows that the albite has a composition of about $\mathrm{An}_{8-9}$. Doubtless its occurrence here is as porphyroblasts, in conformity with a general predilection of this mineral to so crystallize in metamorphic rocks (see Turner and Verhoogen, 1960, p. 583, 597). Presence of the more calcic plagioclase in the groundmass, confirmed here by X-ray, indicates that the albite is a retrograde metamorphic product in the greenstone which otherwise has a metamorphic grade near the lower grade end of the amphibolite facies.

\section{METADIORITE}

The texture of the metadiorite varies irregularly in fine-scale alternation from coarse to fine grained, or coarse phenocrysts of black amphibole may be scattered through a groundmass of the fine-grained dark-gray material. A hornblende, blue green in thin section, is the dominant mineral. Andesine or labradorite and quartz are the other common constituents. The hornblende crystals tend to be rounded in crosssection, and vary greatly in size to as much as a quarter of an inch across. They are full of feldspar and quartz inclusions and have very ragged boundaries. Ragged outliers in crystallographic parallelism with larger hornblende crystals are common in thin sections. The hornblende is further characterized by twinning on a very irregular wavy pattern. Locally, the hornblende contains irregular inclusions of augite which may be in optical parallelism, indicating that it is relict from an original igneous occurrence. In a few places the augite may be present, in part granulated to a mosaic, without conversion to hornblende.

The larger plagioclase crystals, which are a minor constituent of the rock, are in places clear and lath shaped, but, more commonly, they are sericitized, have vague irregular boundaries, and are crosscut 
by zones of fine-grained feldspar and quartz; this suggests that they also are relict from an earlier igneous rock. The finer grained metamorphic feldspars are clear, poorly twinned, and hard to tell from the fine granular quartz. Some untwinned feldspar of low refractive index, presumably orthoclase, is present in the recrystallized groundmass, which also contains fine hornblende, biotite, chlorite, apatite, partly euhedral grains of magnetite, and locally epidote. Thin veinlets of epidote cut the rock and locally contain intermixed orthoclase, plagioclase, and quartz.

The igneous affiliations of the metadiorite are somewhat plainer than those of the greenstone. It was apparently derived from a more basic igneous rock. The petrographic character suggests derivation from a pyroxene gabbro or from a diorite close to the gabbro boundary, and the analysis (table 2) is consistent with this interpretation (see Johannsen, 1937, p. 155, 221; Nockolds, 1954, p. 1019, 1020).

\section{UNCOMPAHGRE QUARTZITE \\ DISTRIBUTION AND THICKNESS}

A quartzite that crops out on both slopes of Silver Creek upstream from the Larsen tunnel has been correlated with the Uncompahgre Formation, exposed 13 miles to the east in the Engineer Mountain quadrangle. The quartzite contains a little interbedded chlorite schist derived from originally shaly beds, and sparse dolomite. Exposures are more extensive on the south slope of Silver Creek, but a few quartzite outcrops are found on the north slope between the Larsen and Last Chance tunnels. The formation is in an upthrust block of irregular shape on the eastward extension of the monzonite north lobe. The block is about half a mile long and a maximum of three-tenths mile wide. Exposures are on the whole poor and disconnected, and show no stratigraphic contacts with other formations. No estimate of thickness can be made, but considering the steep dips, the total represented may well be in excess of 1,000 feet. The rocks that are exposed make up only a small part of the great thickness of Uncompahgre revealed in other parts of the San Juan region.

What is believed to be the same quartzite forms slivers in the fault zone along the north side of the Precambrian greenstone block on both sides of the Dolores River north of Rico.

\section{LITHOLOGIC CHARACTER}

The quartzite is pale gray but commonly has red stains. The constituent quartz grains and pebbles are angular to subrounded and reach a maximum of half an inch across. Induration has been so complete that the bedding is generally obscure, but where bedding can be recognized in the Silver Creek area, it dips $40^{\circ}-90^{\circ}$ between north and east. In some places on the south side of the creek, shaly strata as much as 40 feet thick, originally bedded in the quartzite, have been converted to pyritized chlorite schist layers. A zone of fine-grained light-gray dolomite, perhaps 25 feet thick, is interbedded with the schist at one place in the bed of Silver Creek, 450 feet east of the Larsen tunnel.

Examination in thin section reveals that the quartzite contains interstitial pockets and blebs of coarse sericite, some of which embay or are enclosed in the quartz grains. The quartzite also contains rounded detrital grains of zircon.

\section{CORRELATION AND STRATIGRAPHIC RELATIONS}

The quartzite is correlated with the Uncompahgre Formation (Precambrian) of the Engineer Mountain and Needle Mountains quadrangles on the basis of lithologic and structural similarity. It is much thicker than the Ignacio Quartzite (Cambrian) of areas to the east and southeast. Its steep to vertical dips are incompatible with those of Paleozoic strata in adjacent fault blocks, suggesting that a profound unconformity exists between the two sets of rocks. The Uncompahgre is believed to be the basement rock intersected in deep borings next below the Ouray Limestone (Devonian) at Rico.

The Uncompahgre is doubtless younger than the Precambrian greenstone and metadiorite, for no evidence of its intrusion by these igneous derivatives has been found, either at Rico or elsewhere in the San Juan region where correlatives of these igneous types are known.

\section{EARLY PALEOZOIC HIATUS}

In the Engineer Mountain quadrangle east of Rico, the Precambrian strata are overlain with pronounced unconformity by the Upper Cambrian (Ignacio Quartzite) which is nowhere more than 80 feet thick (Cross and Hole, 1910). The closest exposures are about 13 miles slightly south of east from Rico. At some localities, including one about 15 miles east of Rico, the quartzite has pinched out, presumably owing to pre-Devonian erosion. The Devonian System begins with the Elbert Formation, which is a sequence of calcareous shales, earthy and sandy limestones, in part dolomitic, and locally quartzites and thin conglomerates. Its maximum thickness in the Engineer Mountain quadrangle is nearly 100 feet, but the formation thins northward, presumably by overlap on the underlying surface of an unconformity, and at the closest approach, 13 miles from Rico, is only 10 to 15 feet thick. The Elbert is over- 
lain conformably by the Ouray and Leadville Limestones of Devonian and Mississippian ages, respectively.

At Rico, information on the contact between the Precambrian and Paleozoic strata is obtainable only from the sequences intersected in a few drill holes. Identities of the different strata are subject to interpretation from drill logs of varying worth. No Cambrian quartzite has been recognized in the outcrop; and, if it is present in some of the deep drill holes, it cannot there be distinguished from the Uncompahgre. The quartzite which Cross and Spencer (1900) mapped as "Devonian quartzite," but which Cross and Ransome (1905) later correlated with the Ignacio, is really a Pennsylvanian quartzite. Nothing resembling the Elbert shows in the outcrop or is recognizable in the drill-hole logs. The first strata above the quartzite in hole 118 of the Rico Argentine Mining Co. are logged as "sandy limestone," overlain by purer limestones. If the surmise is correct that the sandy limestone is the Ouray Limestone overlying the Uncompahgre Quartzite, then the earliest Paleozoic sedimentation at Rico began in the Late Devonian. This relation is not unique in the San Juan region, for there are also places in the Needle Mountains, Silverton, and Ironton quadrangles where the Ouray Limestone is the earliest formation laid down on the Precambrian (Cross, Howe, Irving, and Emmons, 1905; Cross, Howe, and Ransome, 1905; Burbank and Luedke, 1964).

\section{DEVONIAN SYSTEM \\ UPPER DEVONIAN SERIES}

OURAY LIMESTONE

The Ouray Limestone probably does not crop out at Rico. Its presence can be surmised only by analogy with other areas to the east and northeast in the San Juan region and by a reasonable interpretation of the $\log$ of diamond drill-hole 118. This hole, drilled by the Rico Argentine Mining Co. in the fall of 1948 on the south side of Silver Creek at the east edge of town, appears to have cut about 162 feet of limestone below the top of the Leadville Limestone (Mississippian), and it penetrated 5 feet into the underlying quartzite. The basal 28 feet of limestone is reported in the log as sandy. This feature suggests the lithology of the Ouray Limestone, some of which is sandy in other areas of the San Juan region where the Devonian crops out closest to Rico (Cross and Hole, 1910; Cross, Howe, Irving, and Emmons, 1905). There is no way of telling from the $\log$ how much additional thickness of limestone may be reasonably classed as Ouray. In the log of the borehole that cut comparable strata on the Atlantic Cable claim (Rickard, 1897), there is no mention of sandiness in the lower part of the limestone, though this feature may well have been overlooked by the log compiler. Probably correlative strata were cut in the two holes. Detrital grains of sand are also recognizable in some of the hornfels boulders on the dump of the Shamrock shaft; this rock is limestone extensively replaced by finegrained metamorphic silicates.

As the nonsandy beds of the Ouray Limestone have not been distinguished from those of the Leadville, the lithology is presumed to be similar to that of Leadville Limestone, to which all outcrops can probably be referred.

\section{MISSISSIPPIAN SYSTEM \\ LOWER MISSISSIPPIAN SERIES \\ LEADVILLE LIMESTONE \\ DISTRIBUTION AND THICKNESS}

The Leadville Limestone is only poorly exposed at Rico, although it must underlie a good part of the townsite. There are exposures at the Shamrock mine on the west bank of the Dolores River, along Silver Creek at the Atlantic Cable mine just west of the main street, and along the northeast outskirts of the town. Only a few feet of strata are exposed at any one place, and, as these are all presumed to be near the top of the formation, no concept of total thickness is obtainable from the outcrop. The maximum exposed thickness is 20 feet at the Shamrock mine.

Underground measured thicknesses of the limestone, as previously indicated, probably include an undetermined interval of the underlying Ouray Limestone. The combined thickness of the two in diamond-drill hole 118 appears to be about 162 feet after correction is made for $18^{\circ}$ of stratigraphic dip. This amount of limestone was cut (along with $17 \mathrm{ft}$ of porphyry) between depths of 235-423 feet. The hole on the Atlantic Cable claim penetrated $1461 \%$ feet of strata, exclusive of porphyry, before entering the Precambrian quartzite (Rickard, 1897). When this is corrected for about $25^{\circ}$ of dip, the stratigraphic thickness indicated is 135 feet. The hole starts below the top of the Leadville Limestone, but the thickness eroded from above the collar of the hole is not believed to be very great. Diamonddrill hole 15, drilled by the Rico Argentine Mining Co. in September 1943, from inside the 88 tunnel, started in Pennsylvanian strata, cut 121 feet of limestones in the Ouray-Leadville interval (from 141 to $262 \mathrm{ft}$ ), and finished in the Precambrian (Varnes, 1944). The true thickness of the limestone 
interval is somewhat less than here indicated, for the drill hole dips $80^{\circ} \mathrm{SW}$. in the probable direction of a low bedding dip, but as the amount of stratigraphic dip is not known and not now measurable on the surface, the correction in thickness is not calculable. The Ouray-Leadville is the stratigraphic unit that was worked in the Van Winkle and Atlantic Cable shafts where, however, the full thickness is not revealed.

The logs of four diamond-drill holes put down by the Pelleyre Mining \& Milling Co. in 1939-40, two near the portal of the New Year (Golden Fleece) tunnel and two in the Lexington tunnel, are difficult to interpret because of poor logging, which included a tendency to $\log$ as limestone, lithologies that are probably limy shales and limy sandstones. If a red shaly conglomerate that is logged in three of the four holes (and can be correlated in the fourth) can be taken as the base of the Pennsylvanian, the thickness of the Ouray-Leadville interval in Newman Hill is 83-88 feet in three of the holes, and 127 feet in the fourth (hole 2). All four holes reached the Uncompahgre Quartzite, and hole 3 probably penetrated 86 feet into it, though this figure involves some reinterpretation of the log.

\section{LITHOLOGIC CHARACTER}

As the only exposures of the Leadville Limestone are near the intrusive stock that crops out west of Rico, the limestone is here recrystallized to a white to gray granular marble. Much of the rock is now dolomite. A little light-gray chert is present in some exposures. Nearly all outcrops contain contact metamorphic silicates. Fine-grained siliceous segregations of gray to purplish-gray color near the top of the limestone at the Shamrock mine are largely such metamorphic aggregates, but they also contain fine detrital silt composed of angular quartz grains, revealed only in petrographic thin section.

The log of diamond-drill hole 15 in the 88 tunnel, prepared by D. J. Varnes, suggests that the limestone of the Leadville-Ouray interval in this area is less marbleized than on the outcrops and is commonly tinged pink or purplish rather than the usual gray and white. There are rare thin partings of green shale.

Although shale is minor in most of the known Leadville, in diamond-drill hole 118 some intervals of poor core recovery as much as 4 feet thick in the upper 14 feet of the Leadville were logged as shale. Elsewhere, a short prospect tunnel on the right bank of Silver Creek, 430 feet east of the Larsen tunnel portal, formerly exposed several feet of very pyritic green mudstone containing a 6-inch quartzite seam. Although there is no associated limestone in the tunnel and the outcrop area is completely obscured by thick surface debris, this mudstone is thought to be Leadville because of contained fossils (see below), and because it is in the proper stratigraphic position relative to the outcrops of Pennsylvanian quartzite near the Larsen tunnel portal. The small patch of Leadville shown on plate 1 is in conformity with this interpretation.

AGE AND STRATIGRAPHIC RELATIONS

Outcrops of the Leadville just south of the Shamrock mine show remnants of fossils, including crinoid stem fragments and a horn coral, but these fossils are so poorly preserved that they disintegrate when attempts are made to collect them. Poorly preserved brachiopod remains collected from the outcrop on Silver Creek, near the Atlantic Cable shaft, provide no evidence for differentiating Upper Devonian strata from Lower Mississippian.

Another outcrop on a low knoll on the slope near the north edge of town contains slightly better preserved fossils, mainly corals, in a cherty phase of the limestone. According to Helen Duncan of the U.S. Geological Survey, the general aspect of the coral assemblage from this locality suggests Mississippian (Leadville) rather than Devonian (Ouray) insofar as the faunas are known in Colorado; however, the objective evidence for Mississippian age is confined to one specimen. Miss Duncan stated (written commun., 1959):

I was lucky enough to get one coral that can be referred with some assurrance to Homalophyllites, a small horn coral that we believe is restricted to the Lower Mississippian and that is common in the Leadville, Madison, and equivalent strata. The sections also revealed other types of small zaphrentoid corals, indeterminate brachiopods, bellerophontid gastropods, Fenestella, and lamellar and ramose bryozoans. The corals in this collection are not at all suggestive of the Late Devonian types that characterize the Percha of New Mexico. The Percha forms occur in the Ouray, but collections do not indicate corals are very common in the Colorado DevonianOuray and Chaffee. *** On external form some of the coral specimens suggest Cyathaxonia. A larger coral with dissepiments might be Vesiculophyllum. The material (other than the Homalophyllites) really is not identifiable on its own merits, but is suggestive of genera commonly found in the Lower Mississippian.

In the now-caved prospect tunnel east of the Larsen tunnel, the pyritic mudstone contained in a thin zone just below the quartzite seam a few poorly preserved fossils consisting of impressions, mainly of dorsal valves, of a small productid brachiopod. These were examined by J. T. Dutro, Jr. (Helen Duncan, written commun., 1959) of the U.S. Geological Survey, who expressed the opinion that they 
are of Carboniferous age and might be Early Mississippian.

The Leadville Limestone presumably overlies the Ouray Limestone conformably, though the contact or transition between them has been transected only in drill holes and possibly in mine workings. The Ouray Limestone, if its presence has been correctly surmised from the sandy nature of the limestone in a drill hole and shaft and from analogy with adjacent areas, must overlie the Uncompahgre Quartzite with profound unconformity.

The Leadville is overlain by the Larsen Quartzite with pronounced unconformity. The contact, however, is nowhere exposed at Rico, either because the two formations occur in separate fault blocks or because surficial debris conceals the contact. At the Shamrock mine where the Larsen Quartzite is apparently missing, the Leadville Limestone is overlain unconformably by the Hermosa Formation.

\section{PENNSYLVANIAN SYSTEM \\ MIDDLE PENNSYLVANIAN SERIES \\ LARSEN QUARTZITE \\ DISTRIBUTION AND THICKNESS}

The Larsen Quartzite is herein named and adopted for the outcrop above the portal of the Larsen tunnel, on the north slope of Silver Creek, where about 77 feet of strata dipping $30^{\circ} \mathrm{SW}$. are exposed. Neither overlying nor underlying strata can be seen here, but projection of the quartzite upper boundary southward to Silver Creek where overlying strata are visible indicates that the exposure at the type area is at, or close to, the top of the unit. The total thickness is unknown, but may not be much greater. The uppermost $511 / 2$ feet of the quartzite is cut in the nearby Ahkeah tunnel, and the uppermost 541/2 feet is cut in the lower and middle Falcon tunnels. In the middle Falcon tunnel, the quartzite strata dip $25^{\circ}-49^{\circ} \mathrm{S}$., but an extension of the tunnel to the northeast crosses a fault and enters the Uncompahgre Quartzite before the base of the Larsen Quartzite is reached.

Other outcrops of the quartzite are scarce, owing to the thick mantling by surface debris in the heart of the Rico district. There is a small isolated exposure at the appropriate stratigraphic position between the Leadville Limestone and Hermosa Formation on the Silver Creek road leading out of Rico, about 300 feet above the first sharp bend (pl. 1). Only 10 feet or so of strata can be seen here. This outcrop is surrounded by surficial material which precludes determination of thickness, but the space available within which the unit could be concealed is too narrow to accommodate the full thickness of strata existing at the type locality, half a mile away. Plate 1 depicts a belt of the quartzite at the surface north of the Falcon workings, but this belt has been projected from the workings and does not crop out. In diamond-drill hole 15 in the 88 tunnel, the 60-foot interval referable to the Larsen Quartzite at a depth of 81-141 feet is doubtless greater than the true stratigraphic thickness, for the drill hole is probably not perpendicular to bedding. In the northeastern part of town, Pelleyre diamond-drill hole 4 cuts quartzite in the 37 -foot interval between depths $521 / 2$ and $891 / 2$ feet, just above the LeadvilleOuray sequence. Although this interval contains minor amounts of what is logged as "sandy limestone," in intercepts as much as $2 \frac{1}{2}$ feet thick, the whole interval can be interpreted as Larsen Quartzite. On the south side of Silver Creek at the east edge of town, diamond-drill hole 118 penetrated, at 193-223 feet in the position just above the LeadvilleOuray sequence, 30 feet of strata logged as "black iron" in sandstone and limestone. The lithologic description at least suggests certain phases of the Larsen Quartzite lithology.

North of Rico, on the east side of the main highway about 500 feet south of the Dolores River bridge, a small outcrop exposes several feet of the quartzite. This exposure must be downfaulted in relation to higher exposures of the Leadville Limestone to the southeast.

The quartzite that crops out for 20 feet above the portal of the Black Wonder tunnel west of the Dolores River was formerly (1931) exposed within the mine, dipping about $6^{\circ} \mathrm{SW}$. On an upper level, 15 feet above the main level, the quartzite is overlain conformably by a highly metamorphosed bed which was probably originally a shaly limestone at the base of the Hermosa Formation. The stratigraphic relations suggest that the quartzite here is the Larsen Quartzite. At 210 feet from the portal (and S. $77^{\circ} \mathrm{W}$. from it) the quartzite in the mine is cut off by a N. $70^{\circ} \mathrm{W}$. fault that drops the strata on the southwest side. Although the quartzite is not exposed again on the surface in the downdropped block, the Montezuma workings were partly in the quartzite (Ransome, 1901, p. 363), which gives a rough indication of the fault displacement, as shown on plate 1.

An isolated outcrop of quartzite on the west bank of the Dolores River opposite the mouth of Silver Creek is probably the Larsen Quartzite. The position of this mass suggests that it is stratigraphically below southeast-dipping Hermosa strata exposed 200 feet to the southwest. At the Shamrock mine, however, only 700 feet south from this quartzite 
outcrop, the unit is apparently missing, and fossiliferous limestone of the Hermosa Formation, considerably altered by thermal metamorphism, is within 5 feet above the Leadville Limestone, though the contact is concealed.

\section{LITHOLOGIC CHARACTER}

The outcrop above the Larsen tunnel reveals a well-indurated quartzite composed of angular to subrounded quartz grains that are predominantly fine grained, but include coarser grains and pebbles of vein quartz as much as 1 inch across. No feldspar is found when the rock is examined in thin sections, but scattered grain-sized nests of sericite suggest alteration from feldspar grains. The quartzite contains subrounded pebbles, as much as 2 inches across, of an earlier quartzite, possibly derived from the Uncompahgre. On an extensive dip slope whose horizon is 29 feet below the top of the exposed section, the rock contains sparse subangular fragments of fossiliferous gray chert, commonly as much as 1 inch across and exceptionally as much as 9 inches. The quartzite is pale gray to brown, locally dark gray, or red tinted. Except for its distinct, though rather massive, bedding, this quartzite is very similar to that composing the Uncompahgre Quartzite.

The quartzite in the upper part of the formation, as revealed in the Ahkeah tunnel, is well bedded and has thin intercalations of pale-gray or drab siltstone or shale. The occurrence of the finer grained material as a matrix for the quartz grains, even in the most indurated quartzite, is peculiar to, and characteristic of, this part of the section. Some of the quartzite is slightly less indurated than the rock exposed on the surface. Some of it is also nearly black from contained pyrite and chlorite. In other beds, the quartz grains show a distinct red tinge (rose quartz). The following section was measured in the Ahkeah tunnel, where the strata strike approximately at right angles to the course of the tunnel.

Section of upper Larsen Quartzite in Ahkeah tunnel [Measured by E. T. McKnight and James Marlowe]

Thickness
(feet)

Lower Hermosa Formation:

13. Dolomite, gray to pale-gray, massive, coarsegrained, porous; contains disseminated pyrite and sphalerite; at $12 \frac{1 / 2}{\mathrm{ft}}$ above base is a 1 -ft green shale parting, above which the dolomite for a few feet is greenish, shaly, and better laminated. Lower contact conformable

Larsen Quartzite:

12. Quartzite, pale-gray, gray, and a little darkgray

11. Shale, pale-gray
10. Quartzite, gray, pale-gray, pale-brownishgray, and a little dark gray; locally has been leached to very friable sand -..----

9. Shale, pale-gray, laminated (quartz siltstone?) - -

8. Quartzite, gray, pale-gray, pale-brownishgray, and dark-gray; locally pyritic; grains as large as $1 / 4$ in. At $7 \frac{1}{2} \mathrm{ft}$ above base is a 3 -in. pale-gray shaie parting -...--_.-- 1

7. Shale, pale-gray, laminated -...--

6. Quartzite, gray and brownish-gray to darkgray; locally finely pyritic; lower part a little softer than typical quartzite; some of quartz grains as large as $1 / 4$ in., and some of these reddish; one questionable reddish feldspar grain; grades into underlying unit - - -

5. Like unit 4 , but many more quartz grains (some to nearly $1 / 4$ in.) and not laminated; looks like quartzite, but soft, though locally grades to quartzite --.---.---

4. Fine quartz siltstone, pale-gray; looks in places like quartzite but soft; some palegray shale, laminated, containing scattered quartz grains

3. Quartzite, brownish, gray, and dark-gray to almost black (pyritic, chloritic); some with reddish tinge; grains as large as $1 / 4$ in. in places. A 1-in. parting of light-gray

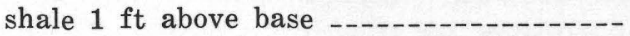

2. Siltstone, pale drab; contains abundant subrounded quartz grains as large as $1 / 8$ in.; indefinite boundary with underlying unit_-

1. Quartzite, gray, with quartz grains as large as $1 / 4$ in _...

[Base of section at breast of tunnel.]

Total Larsen Quartzite

The section of upper Larsen Quartzite cut in the Falcon tunnels is comparable to that in the Ahkeah. At the outcrop between the Leadville Limestone and Hermosa Formation on the Silver Creek road, the quartz grains and pebbles that make up the quartzite are distinctly red; some pebbles may be as much as half an inch in diameter. Some of the rock here shows the quartz grains imbedded in a metamorphosed argillaceous matrix. Inside the Black Wonder mine, much of the quartzite has a greenish-gray cast from finely divided chlorite that occurs in the matrix. Thin sections of the quartzite from this locality also show considerable sericite and sparse fine zircon crystals.

AGE AND STRATIGRAPHIC RELATIONS

Cross and Spencer (1900) mapped the Larsen Quartzite together with the Leadville Limestone as undifferentiated "Devonian"; from their interpretation of spatial relations of the strata on the west side of the Dolores River opposite the town of Rico, 
they considered that the quartzite was below the Leadville (and Ouray?) Limestone rather than in its true position above this limestone. In accordance with their concept, the Precambrian quartzite below the limestone was misidentified as "Devonian" quartzite in the interpretation of a boring on the Atlantic Cable claim. Later, Cross and Ransome (1905), on the basis of information obtained from other parts of the San Juan region, differentiated the quartzite from the limestone and classed it as Ignacio Quartzite, of Cambrian age.

The scattered chert fragments exposed on the dip slope of the quartzite above the Larsen tunnel contain a few fossils. For the most part, these fossils are exposed on hard flat rock faces where they cannot be collected without special rock-breaking equipment. Several such fossils located by the author were examined (1957) in place by Prof. Walter Sadlick, of the University of Houston, who observed "an external mold of a fenestellid bryozoan" and another fossil which "probably is an orthoconic nautiloid with a subcentral siphuncle. It might be a Mooreoceras, which is quite common in Mississippian and Pennsylvanian strata" (Walter Sadlick, written commun., 1957).

Fragments of chert pebbles from this locality were examined by Helen Duncan, of the U.S. Geological Survey, who reported (written commun., 1959) small crinoid columnals and Fenestella remains.

This bryozoan genus ranges from Late Ordovician to Permian. $* * *$ The possibility that the bryozoans in this lot could have come from the Ordovician is eliminated by the stage of evolutionary development exhibited by the zooecia. The primitive Ordovician species has rectangular zooecia. One specimen in the chert has triangular to pentagonal zooecia, which are indicative of more advanced species. Since Silurian and Early and Middle Devonian sediments probably never were deposited in this region, it is reasonable to assume that the source of the cobbles must have been Upper Devonian or Carboniferous rocks. As described, the Elbert does not seem to be a very likely source of bryozoan-bearing chert. I do not know whether the Ouray contains chert of this type. In any event, if the cobbles came from the Ouray or younger rocks, the age of the enclosing quartzite is presumably Carboniferous.

Although calcareous sandstone is locally present at the base of the Leadville Limestone in the Ouray quadrangle (Luedke and Burbank, 1962), clastic strata of Mississippian age are in general scarce in the San Juan region. On the other hand, the succeeding strata of Pennsylvanian age commonly contain sandstones and arkoses, and these are locally indurated to quartzites. In much of the San Juan region, the initial Pennsylvanian deposit is the Molas Formation, which generally holds abundant chert pebbles containing a Mississippian fauna (Larsen and Cross, 1956, p. 45). Although the Larsen Quartzite bears little resemblance to the Molas Formation, it is at the same stratigraphic position and is conformable beneath the succeeding Hermosa Formation. The Larsen Quartzite is probably a lateral equivalent of the Molas, lying at the base of the Middle Pennsylvanian and containing the same chert pebbles that characterize the Molas.

The logging of the four Pelleyre diamond-drill holes on Newman Hill contains some puzzling discrepancies, but a conglomeratic unit, 26-27 feet thick, recorded near a depth of 1,000 feet in the two holes drilled from the Lexington tunnel and recognizable at correlative positions in the other two holes, may be the Molas equivalent of the Larsen Quartzite. The conglomerate is described as a red or green sandy or calcareous shale or claystone containing pebbles and boulders of gray to pink limestone and angular fragments of white, red, and dark-gray "quartzite." If some of the quartzite can be reinterpreted as chert, the unit would appear to be very similar to descriptions of the Molas Formation (Larsen and Cross, 1956, p. 45). The closest outcrops of the Molas are in the Engineer Mountain quadrangle, about 12 miles east of Newman Hill.

The contact of the Larsen Quartzite with the underlying Leadville Limestone is not exposed at Rico. However, an exposure on the slope northeast of town, believed to be near the top of the Leadville Limestone, reveals certain features that may throw some light on the nature of the contact. The limestone here contains pockets and irregular lenses of fine-grained siliceous material in which are embedded subrounded grains of detrital red and bluegray quartz, as much as one-eighth inch in diameter. These pockets and lenses are only a few inches long, and they anastomose along and across bedding planes without recognizable pattern. As the marbleized limestone between them is free of sand, it appears that the sand grains were introduced at the beginning of Pennsylvanian sedimentation and filtered down into solution cracks and crevices that had formed in the upper part of the limestone during the preceding period of erosion. The matrix of the sand was replaced by fine-grained silicates during the later thermal metamorphism, but accompanying chertlike silica may be relict from the period of sand filling.

The occurrence in the Larsen Quartzite of pebbles from an earlier quartzite formation suggests that at the beginning of Pennsylvanian deposition the Uncompahgre Quartzite, or possibly the Ignacio, was being eroded in the general vicinity. Increase 
in thickness of the Larsen Quartzite from west to east in the Rico district suggests approach to the upland from which the material was being derived. If the surmise is correct that the drill holes in Newman Hill cut the Molas facies of the basal Pennsylvanian, the quartzite facies also appears and thickens from south to north within the district. Thus, it seems probable that the Larsen Quartzite may overlap the Leadville and Ouray Limestones east or northeast of Rico and rest on earlier quartzite. The edge of the overlap, however, is not now evident.

In summary, the evidence seems clear that the Larsen Quartzite overlies the Leadville Limestone unconformably and contains chert fragments that were derived from erosion of this limestone. It may well overlap the Leadville east or northeast of Rico and rest unconformably on the Uncompahgre Quartzite. The exposures in the Ahkeah and Falcon tunnels show that the quartzite is overlain conformably by the Hermosa Formation.

HERMOSA FORMATION

GENERAL FEATURES, THICKNESS, AND DISTRIBUTION

The Hermosa Formation, which constitutes the bedrock over a wide area in the Rico district, is a thick series of interbedded sandstones, arkoses, shales, conglomerates, limestones, and dolomites aggregating perhaps 2,800 feet in thickness. Although the proportions of these types of rock vary in different levels of the section and also laterally, the lithologic character remains much the same throughout. Thus, the sandstones are generally feldspathic, somewhat micaceous, and greenish gray, but they become increasingly, though irregularly, reddish toward the top of the Hermosa. The shales are greenish gray to nearly black, but they also take on red tints upward. The limestones are gray, fine grained, bituminous, and generally fossiliferous. There is much gradation between the sandstones and shales, both vertically and laterally, and they are variably limy. Hence, the sequence and proportions of the different rock types are never the same in closely adjacent sections. Even many of the limestone beds lack lateral persistence over the district, though they are more likely to disappear by thinning than through dilution with clastic material.

The limestones are concentrated chiefly in the middle part of the Hermosa Formation and the conglomerates in the upper part. Thus, the formation is divisible into lower, middle, and upper parts differing in lithologic aspect. This was recognized by Cross and Spencer (1900, p. 49-59), and their subdivision is followed in the present report, though the terminology differs slightly.
Because extensive landslide and talus debris mantles most of the lower slopes of the Rico Mountains, exposures of the lower Hermosa are small and disconnected. The portals of tunnels that cut this part of the section are largely caved, and the workings that are still open commonly have bad air; hence, less stratigraphic information is now obtainable than formerly when such workings were accessible. Prevalence of faulting and the abundance of igneous sills and dikes further disrupt the stratigraphic continuity. The sequence of strata and thickness of the lower Hermosa are, therefore, only poorly known, except for the basal 95 feet and upper 400 feet. The basal part is exposed in the Ahkeah and lower Falcon tunnels; the upper part is exposed at the base of the Sandstone Mountain section, 2 miles north of Rico, and on the south side of Deadwood Gulch.

The middle Hermosa is well exposed in the steep cliffs and ledges of Sandstone Mountain, where the strata dip north at $11^{\circ}-18^{\circ}$ into the mountain but are otherwise relatively undisturbed. The middle Hermosa also crops out extensively in the high ledges above Newman Hill, a mile southeast of Rico. Elsewhere, as on the north slope of Silver Creek in the vicinity of the Yellow Jacket mine, the sequences are not complete enough to yield much stratigraphic information. The middle division shows a pronounced facies change, from limestones alternating with dominantly clastic strata in Sandstone Mountain and on upper Silver Creek to predominantly limestone in the exposures above Newman Hill.

The upper Hermosa is exposed near the top of Sandstone Mountain and in the ridge leading from there northwest toward Elliott Mountain, but the section is incomplete and complicated by several faults. Missing parts of this section crop out near the mouth of Marguerite Draw, just north of the area shown on plate 1. Less complete exposures are found in the southward-ascending cliffs east of the Dolores River opposite Sandstone Mountain, in the mining area up Silver Creek, and in the high slopes above Newman Hill.

$$
\text { LITHOLOGIC CHARACTER }
$$

As the Sandstone Mountain section is the best exposure of the Hermosa for many miles, it is herein given as a standard for reference. The Marguerite Draw exposures supply that part of the section that does not crop out at the top of the mountain. Because the limestones of the middle Hermosa are the strata that are most commonly mineralized in the mining areas, they are of special economic interest and are accordingly given special letter designations in the 
section. These designations are the same as those used by the St. Louis Smelting \& Refining Co. in their mapping of mine workings in CHC Hill.

Partial section of strata near and at top of Hermosa Formation on Sandstone Mountain ridge, north side of Sandstone Mountain fault

[Section measured by E. T. McKnight and C. S. Hurlbut, Jr. Above the units here recorded there are, from the top down, $133 \mathrm{ft}$ of Rico strata (containing an additional 49-ft porphyry sill); then an $8-\mathrm{ft}$ porphyry sill; then $71 \mathrm{ft}$ of Rico strata down to the beginning of the recorded section

Lower part of Rico Formation:

113. Arkose, crossbedded, mostly pale-purplish, some greenish; color is streaked along the bedding; has the usual pink to reddish quartz and feldspar grains; some muscovite

112. Limy shale, red, micaceous; contains numerous gray and reddish limestone nodules; top $5 \mathrm{ft}$ contains ledges as much as $1 \mathrm{ft}$ thick of reddish shaly sandstone, thin bedded and micaceous -

111. Arkose, rather coarse, becoming conglomeratic especially near top, crossbedded, pinkish, top $5 \mathrm{ft}$ purplish red; rounded pebbles as large as 2 in. of gray, pink, and reddish quartzite, red granite, white quartz, 1-in. pebble of reddish orthoclase

110. Concealed; from exposures elsewhere, this is a greenish micaceous sandy shale -..-

Total Rico Formation (including parts not here described)

- -

Upper Hermosa:

109. Concealed; from exposures elsewhere, basal foot of concealed interval is a Fulsulinabearing shaly limestone bed that is taken as the top of the Hermosa

108. Shaly sandstone, maroon, thin-bedded, very micaceous

107. Arkose, greenish; becomes redder in upper half, crossbedded; has numerous pinkish fragments of both quartz and feldspar, some muscovite; has pale-greenish shale pellets about $18 \mathrm{in}$. above base .......

106. Shale, blackish to greenish, micaceous; in part sandy, the sandier phases becoming greener. (This is the same as unit 106 of the Marguerite Draw section, see following.) $(9+\mathrm{ft})$.

[Section ends at lowest exposure on east side ridge; resumes on west bank of Dolores River a few hundred feet north of Marguerite Draw.]

Partial section of upper Hermosa Formation near mouth of Marguerite Draw, on spur between this draw and Dolores River (just north of area shown on $p l$. 1)

[Section measured by E. T. McKnight and E. B. Eckel. Numbering of correlated units is same as in preceeding section]

Higher strata not exposed.

Upper Hermosa:

107. Sandstone, purplish to light greenish gray. (Thickness not determined).
Partial section of upper Hermosa Formation near mouth of Marguerite Draw, on spur between this draw and Dolores River-Continued Thickness
(feet)

Upper Hermosa-Continued

106. Shale, greenish, finely micaceous, thinly laminated; contains a very few limy nodules carrying very fine crinoid stems; top $6 \mathrm{ft}$ more sandy

105. Limy sandstone and sandy limestone, greenish-gray -

104. Sandstone, light-greenish-gray; purplish at top -

103. Sandy shale, red-brown, micaceous, thinbedded; a little gray limy shale -.---.--

102. Conglomeratic arkose, purplish; a few rounded greenstone pebbles among the

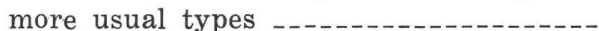

101. Sandy micaceous shale, red-brown -..---

100. Arkose, purplish, coarse; conglomeratic in a few beds though rather finely so. (Unit 100 decreases in thickness up the dip to nothing in about $200 \mathrm{ft}$ )

99. Sandy shale, brownish-red _...-..---

98. Conglomeratic arkose, purplish, crossbedded; contains subrounded pebbles of pink granite as large as 3 in., some of very coarse granite, some of purplish sandy shale as large as 2 in., and a few of schist

97. Shaly limestone, reddish-brown, and micaceous limy shale; contains nodular zones of gray limestone in lower third; in upper part limestone occurs as gray nodules in the shale. Top 6 in. is gray shaly limestone

96. Shaly limestone, gray; grades to overlying unit

95. Concealed (top $20 \mathrm{ft}$ of this interval on opposite side of Dolores River is brownish-red micaceous sandy shale and shaly sandstone, the latter more purplish) -..-

94. Arkose, light-greenish-gray, crossbedded --

93. Arkose, light-greenish-gray, crossbedded, coarse, conglomeratic; contains pebbles and cobbles of pink granite, gray granite (4 in., subrounded), flesh-colored chert (3 in., subrounded), white quartz (2 in., subrounded)

92. Limy shale, greenish-gray, containing limestone nodules 1 in. or less across _...-.

91. Sandstone, purplish, micaceous, becoming arkose at top _...

90. Arkose, light-greenish-gray, crossbedded, coarse, conglomeratic in places; contains pebbles of pinkish granite as large as $2 \frac{1}{2}$ in., black and gray chert as large as $1 \frac{1}{2}$ in., dark schist (a little), shale, and subrounded quartzite, and smaller grains of pinkish quartzite, pinkish angular quartz, and glassy quartz as large as $1 / 2$ in.; 1 pinkish orthoclase crystal $1 \mathrm{in}$. long, $1 / 2 \mathrm{in}$. wide; less conglomeratic

\section{1}

$61 / 2$ 
Partial section of upper Hermosa Formation near mouth of Marguerite Draw, on spur between this draw and Dolores River-Continued

Upper Hermosa-Continued

beds (in upper half) have muscovite.

(This is the same as unit 90 of the Sand-

stone Mountain section, see following.)

$(14+\mathrm{ft})$.

[Section ends at lowest exposure near creek level of Marguerite Draw.]

\section{Section of Hermosa Formation on Sandstone Mountain,} Rico

[Section measured by E. T. McKnight and C. S. Hurlbut, Jr. Above the units here recorded, about 58 additional $\mathrm{ft}$ of strata is exposed to top or hill on ridge, but sequence is confused by other igneous intres exposed near mouth of Marguerite Draw ]

\section{Upper Hermosa:}

91c. Porphyry sill (571/2 ft).

91b. Arkose, light-greenish-gray, crossbedded $\left(13 \frac{1}{2} \mathrm{ft}\right)$.

91a. Lower part is reddish micaceous slightly sandy shale; upper part is greenish nonmicaceous shale $\left(6 \frac{1}{2} \mathrm{ft}\right)$.

90. Arkosic conglomerate, with rounded boulders and pebbles as much as 6 in. in diameter on certain crossbedding planes (except in top $5 \mathrm{ft}$ which has no pebbles); besides the usual angular fragments of orthoclase, pebbles include pink quartzite, gray quartzite, white quartz, pink coarse-grained granite ---

89. Limy shale, reddish and greenish gray; contains limestone nodules of their re-

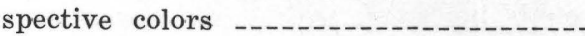

88. Arkose, light-greenish, crossbedded, rather coarse; the pebbles in some layers are as much as $1 \mathrm{in.}$ or more in size, following types noted: white quartz (as much as 2 in.), pinkish quartzite, gray quartzite, pinkish muscovite granite, black argillite (very little). A 2-ft red-brown limy shale parting, 20-22 ft above base, has a few limestone nodules. Upper $7 \mathrm{ft}$ or so of unit is somewhat finer grained, greener, not so evidently arkosic

87. Dominantly gray shaly limestone and gray sandy limestone, but some grades to limy shale (which may have limestone nodules) and greenish limy sandstone, all in beds less than $1 \mathrm{ft}$ thick; a 3 -ft bed of greenish crossbedded sandstone is about $15 \mathrm{ft}$ below top; some of beds take on a reddish tinge

86. Shale, fairly limy, maroon (except greenish in top foot); contains maroon limestone nodules; has lenses of greenish sandstone, especially at base, that lens out in short distances along strike; sandstone shows feldspar, quartz, and mica --

85. Arkose, very pale greenish, crossbedded,
Section of Hermosa Formation on Sandstone Mountain, Rico-Continued

\section{Upper Hermosa-Continued} coarse-grained; some rounded pebbles in a few seams as much as $1 \mathrm{in.}$ across --

84. Shale, greenish, fissile; contains limy nodules and gray limestone seams as much as 3 in. thick irregularly scattered through (but especially in lower half); laterally unit takes on red tinge

83. Arkose, greenish, micaceous, crossbedded; has calcareous cement; 2 or 3 reddish and greenish shale partings as much as $1 \mathrm{ft}$ or so thick

82. Black fissile micaceous shale below, grading to greenish shaly thin-bedded sandstone above; some gray shale in top $18 \mathrm{in.}$.-

81. Sandy limestone, fossiliferous, in 2 beds, upper bed about 15 in. thick

80. Shale, black, very finely micaceous, fossiliferous; has 6-in. black earthy fossiliferous limestone about $6 \mathrm{ft}$ above base; upper $10 \mathrm{ft}$ (except top foot) is sandy, more micaceous, and weathers greenish.

79. Limestone, very dark gray, fossiliferous --

78. Sandstone, in part arkosic, greenish, crossbedded _.........-.

77. Shaly sandstone, greenish, micaceous -.--

76. Shaly limestone, gray and (mostly in lower half) brownish-red; some of the reddish material, which is a little sandy, shows ripple marks and fine-scale crossbedding in a bed about $1 \mathrm{ft}$ thick. Whole unit gives very nodular effect, and especially in upper gray part, nodules of pure gray limestone occur embedded in the more shaly part, and nodules may increase laterally so that shale grades to limestone with numerous thin shale partings; member very limy in top $5 \mathrm{ft}$

75. At base, shaly limestone, gray, some showing mica; grades $3 \mathrm{ft}$ above base to greenish, gray, and reddish limy micaceous sandstone

74. Limy shale, alternating red-brown (dominant) and greenish, the red brown being finely micaceous (and generally slightly sandy) but the greenish not; some seams as much as $1 \mathrm{ft}$ thick of greenish-gray micaceous sandstone (including top foot, which is crossbedded), but these may give way laterally to the reddish-brown shale. [Moved east about $300 \mathrm{ft}$ on this unit.]

73. Arkose, coarse, greenish, micaceous, crossbedded; forms top of cliff _......-

72. Shale, slightly limy, dark-greenish-gray -

71. Limestone, fine-grained, dark-gray; in beds about $1 \mathrm{ft}$ thick, slightly sandy in places; not very fossiliferous

70. Shaly limestone, nodular, bluish-gray, very thin bedded; has brachiopods and large

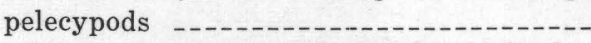
Thickness
(feet)

$11 \frac{1}{2}$

6

$231 / 2$

7

2 
Section of Hermosa Formation on Sandstone Mountain, Rico-Continued

Upper Hermosa-Continued

68. Arkose, greenish; some of quartz and feldspar grains very coarse; very limy in certain bands; forms massive cliff -..--

67. Sandstone, limy, greenish, poorly bedded horizontally; $17-22 \mathrm{ft}$ above base is very limy, almost sandy limestone in part, and has a few crinoid stem fragments

66. Dominantly limy shale, black, finely micaceous; has limestone both as thin bands and as irregular nodules; a little very fine grained limy sandstone especially in basal $5 \mathrm{ft}$. Limy shale and limestone are very fossiliferous

65. Arkose, micaceous, greenish, crossbedded --

64. Very limy sandstone, fine-grained, micaceous, thin-bedded, fossiliferous; has lenticular limestone partings, most conspicuous of which is a parting 3 in. thick

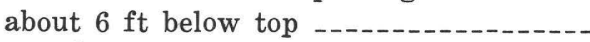

63. Limy shale, black, finely muscovitic; about 3. ft below top, has a 6 -in. black fossiliferous limestone ledge

62. Limestone, fine-grained, very dark gray, bituminous, fossiliferous _-_........

61. Limy sandstone, fine-grained, greenish, thin-bedded, with interbeds of sandy and shaly limestone; unit very similar to upper part of unit 59 but averages perhaps a little sandier

60. Limy sandstone, greenish, muscovitic; forms massive ledge _................

59. Shaly limestone, dark-gray; some black limestone and black limy shale near base which weathers back like a shale slope, but upper part tends to form a cliff; $42-45 \mathrm{ft}$ above base is more sandy but above this is fine-grained limy sandstone or limy shale, averaging a little sandier than below $42 \mathrm{ft}$; whole unit is thinbedded

Total upper Hermosa (composite of 3 sections )

Middle Hermosa :

58. L bed limestone, fine-grained, dark-gray, bituminous, very fossiliferous (corals and other fossils)

57. Porphyry sill $(75 \mathrm{ft})$.

56. L bed limestone, fine-grained, dark-gray, in part shaly, highly fossiliferous, thinbedded but poorly so; upper $6 \mathrm{ft}$ more or less cherty

55. Shaly limestone, dark-gray, weathers greenish; alternates with a little greenish finegrained limy sandstone. More shaly parts are micaceous. (To northeast, near Burns, has abundant phosphate pebbles as much as $1 / 2$ in. in diameter in top $2 \mathrm{ft}$ )

54. Sandstone, greenish, crossbedded ..... $51 / 2$
Section of Hermosa Formation on Sandstone Mountain, Rico-Continued

Middle Hermosa-Continued

53. Limy shale, dark-gray -.......-...-..-

52. Shaly limestone except for 6-in. zone 2$21 / 2 \mathrm{ft}$ above base which is fairly pure dark-gray limestone. Below this limestone, unit is brownish red; above, it is greenish gray. Limestone tends to form nodular segregations in the more shaly parts

51. Shale, brownish-red, basal foot greenish; fairly limy throughout, but an especially limy zone, about $1 \mathrm{ft}$ thick, is $2-3 \mathrm{ft}$ above base

50. Sandstone, micaceous, greenish (except top 6 in. has reddish tinge), horizontally bedded. Basal foot is shaly; a 6-in. brownish-red micaceous shale (probably sandy) has top $2 \frac{1}{2} \mathrm{ft}$ below top of unit. Some green shale pellets in lower part of unit

49. $\mathrm{K}$ bed limestone, fine-grained, dark-gray, bituminous, poorly bedded -..-.-.-.--

48. Arkose, greenish, crossbedded, micaceous; a 1-ft shaly zone about $12 \mathrm{ft}$ above base --

47. J bed limestone, fine-grained, dark-gray ---

46. Sandstone, greenish, horizontally-bedded, 1 or 2 thin crossbedded units less than 1 ft thick; basal foot is dark-gray sandy shale

45. I bed limestone, fine-grained, dark-gray, bituminous; has crinoid stem fragments, massed especially in top foot. (To northeast, near Burns, contains considerable dark-gray chert in bands 2-3 in. thick.) -

44. Sandstone, greenish, both crossbedded and poorly bedded horizontally; a little finer grained and thinner bedded in upper half; 2 - or 3 -in. shale parting $6 \mathrm{ft}$ below top; upper 6 in. very limy and has crinoid

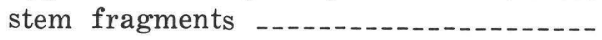

43. Alternating blackish sandy shale (predominant) and greenish shaly sandstone, thinbedded

42. $\mathrm{H}$ bed limestone, dark-gray; has crinoid stem fragments; poorly bedded in 1- to 3 -in. beds, but tends to crop out like other limestones in massive cliff .......

41. Sandstone, micaceous, greenish, poorly crossbedded and horizontally bedded; has a few thin shaly zones -..........

40. Sandy shale, alternating greenish and brownish-red, the green being less sandy; a 2-ft zone, 2-4 ft above base, has reddish-brown limestone nodules ( $\mathrm{G}$ bed) in brownish-red mica shale; greenish limy nodules occur rather sparingly in a green shale higher up --_-_-_-_-_-

39. Arkose, micaceous, greenish; obliquely crossbedded in beds as much as $2 \mathrm{ft}$ thick, alternating with horizontal bedding -.-
Thickness
(feet)

2

5

$71 / 2$

16

3

$391 / 2$

$91 / 2$

$13 \frac{1}{2}$

$65 \frac{1}{2}$

14

$131 / 2$

$111 / 2$ 
Section of Hermosa Formation on Sandstone Mountain, Rico-Continued

Middle Hermosa-Continued

38. Very limy shale, practically a limestone,

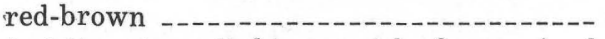

37. $\mathrm{F}$ bed limestone, light-greenish, fine-grained to almost dense

36. Sandy shale, micaceous, greenish; has nodules of greenish and reddish-brown limestone

35. Sandstone, micaceous, greenish, with reddish to purple tinge in top foot; partly crossbedded, partly horizontally thin bedded

34. E bed limestone, gray, poorly bedded; has crinoid stem fragments and brachiopods. At 1-7 ft below top is 6-ft zone that has layers, discontinuous lenses and nodules, as much as $3 \mathrm{in}$. thick, of black chert --

33. Shaly sandstone, fine-grained, micaceous, thin-bedded; reddish in lower half, greenish in upper; top foot is shale, dark-gray to black

32. D bed limestone, fine-grained, gray; contains crinoid stem fragments; about $5 \mathrm{ft}$ below top has lenses of gray chert over a zone with a maximum thickness of $1 \mathrm{ft}$, though generally a main lens 3 or 4 in. thick

31. Sandstone, rather fine grained, micaceous, greenish; becomes shaly in places; thin bedded on the whole

30. Porphyry sill. Shows crude parting parallel to bedding and a jointing perpendicular to bedding. Locally shows hornblende laths parallel to bedding ( $331 / 2 \mathrm{ft})$.

29. Arkose, gray with slight greenish tinge, crossbedded; basal $3 \mathrm{ft}$ very coarse and contains black shale pellets

28. Sandy shale, dark-gray, micaceous; becomes greenish shaly sandstone in top $3 \mathrm{ft}$

27. C bed limestone, fine-grained, gray; in beds about $1 \mathrm{ft}$ thick; forms massive ledge; basal foot is sandy. Has crinoid stem fragments (including basal foot), a few as much as $1 / 2 \mathrm{in}$. in diameter ........

26. Sandstone, fine-grained, greenish, micaceous; has a few thin shale partings including basal 6 in.

25. Limestone, fine-grained, dark-gray; weathers brownish

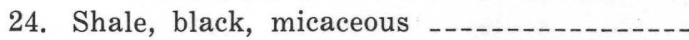

23. Sandstone, micaceous, greenish-white; bedding near horizontal on 1- to 2 -ft scale, but not very pronounced, and some cross-

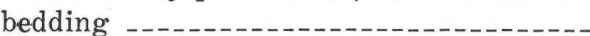

22. Sandstone, very fine grained (almost a shale), thin-bedded, dark-gray; weathers greenish

21. Shale, black micaceous

20. B bed limestone, very dark gray, blacker
Section of Hermosa Formation on Sandstone Mountain, Rico-Continued

Middle Hermosa-Continued

than usual, bituminous odor; has many small white crinoid stem fragments and segregations of calcite
$11 / 2$

1

$14 \frac{1}{2}$

29

$13 \frac{1 / 2}{2}$

21

$11 \frac{1}{2}$ 14

$12 \frac{1}{2}$

24

$12 \frac{1}{2}$
[Unit 20 was followed northeast about $1 / 2$ mile from nose of spur, to where it had decreased to $2 \mathrm{ft}$ thick.]

19. Sandstone, greenish; coarser than underlying unit, crossbedded; top foot or so may be fine grained

$81 / 2$

18. Sandstone, fine-grained, greenish, micaceous; texture varies from almost shale (thin-bedded) to a coarser grained arkose, the latter in beds 1-2 ft thick ----

17. A bed limestone, fine-grained, dark-gray; contains crinoid stem fragments; beds 5 $10 \mathrm{ft}$ thick. Forms ledge overhanging road in cliff

Thickness (feet)

Total middle Hermosa

Lower Hermosa:

16. Arkose, greenish-white, crossbedded; varies in texture from place to place, some beds showing $1 / 4-i n$. grains, some partings fine grained; a little mica in the arkose. Forms massive cliff that shows rounded corrugated flutings brought out by bedding planes -...--

15. Alternating black micaceous shale and darkgray fine-grained micaceous sandstone, latter weathering greenish; all thin bedded. Has a 2 -ft arkose bed whose top is $5 \mathrm{ft}$ below top of unit, also some arkose in top $5 \mathrm{ft}$

14. Limestone, arkosic; weathers brownish ---

13. Sandstone, fine-grained, micaceous, darkgray; weathers greenish; thin bedded --

12. Sandstone, limy, greenish, micaceous; contains a few shaly partings in lower third, which is horizontally bedded and rather thin bedded, upper part being more massive and crossbedded. Sandstone becomes coarse grained and arkosic in certain seams, the top 1-5 ft especially so, with feldspar and quartz grains as much as 1 in. across, rounded pebbles of whitish to gray quartzite as much as 2 in. across, and rounded fragments of red, black and gray chert (the red chert not so large and rather rare, the black also uncommon

[This arkose bed at top was followed from water level of Dolores River for a few hundred feet downstream to where additional underlying strata are exposed.]

11. Shale, black, micaceous; has plant remains - -

10. Limestone, fine-grained, dark-gray, weathers brown; bedding 1-6 in.; a few black shale partings. Has crinoid steam fragments and cup-type corals _..........--

9. Sandstone, greenish, fine-grained, shaly, 
Section of Hermosa Formation on Sandstone Mountain, Rico-Continued

Lower Hermosa-Continued

Thickness (feet) micaceous, thin-bedded; grades laterally within $300 \mathrm{ft}$ to shale and limestone of the type overlying the unit

8. Arkose, greenish, muscovitic; crossbedded obliquely at low angle in beds 1-2 ft thick, which alternate with horizontal bedding. Base has pebbles of underlying unit (which is rather shaly at very top) as much as 2 in. across. Forms massive cliff

7. Sandstone, greenish, fine-grained, thinbedded, almost a shale; very muscovitic. Upper half is less shaly

6. Shale, black, muscovitic, somewhat sandy, in a few places limy; has a few thin seams of fine-grained sandstone. Grades into overlying unit

5. Limestone, fine-grained, dark-gray; weathers brownish; bedding 1-6 in. thick

[Moved downstream on this bed and across a small fault, up about $20 \mathrm{ft}$ on southwest side.]

4. Arkose, massive, greenish, crossbedded; contains irregular quartz grains as much as $1 / 4$ in. across and somewhat smaller white feldspar grains; slightly muscovitic in places. Weathers to massive cliff that shows rounded irregularities produced by bedding and jointing -

3. Same as unit 1. Has 2 in. of arkose, $2 \mathrm{ft}$ above base

2. Sandstone, massive, greenish

1. Sandstone, greenish, fine-grained, muscovitic; weathers thin-bedded; more shaly zones 7-11 ft above base, and in top foot

[Section ends at Dolores River bed.]

Total exposed lower Hermosa _-______-_ 293

Total exposed Hermosa Formation (composite)

In Sandstone Mountain, 293 feet of strata referable to the lower Hermosa is exposed below the prominent limestone which here forms the base of the middle division. A thicker section, on the south side of Deadwood Gulch near its mouth, exposes the top 400 feet (approximately) of the lower Hermosa, though the upper part of this section is complicated by faulting. The strata are dominantly sandstones, siltstones, and arkoses, some shales, and a few thin beds of limestone or dolomite. No strata can be correlated from one section to the other.

The sandstones, siltstones, and arkoses are micaceous and greenish gray, weathering to buff. The finer grained material weathers to thin-bedded, slabby outcrops, whereas the coarser sandstones and arkoses are more massively bedded or crossbedded.
A few of the arkoses contain angular fragments of feldspar or quartz as much as an inch long, though generally a quarter of an inch or less; they also contain scattered rounded quartzite and chert pebbles as large as 2 inches. The shales are greenish gray to black and are finely micaceous.

Two beds of dark-gray dense dolomite, 4 and 6 feet thick, occur at 103 and 235 feet, respectively, below the top of the lower Hermosa in the Deadwood Gulch section, but they are not represented at Sandstone Mountain. The only limestone in the Deadwood Gulch section is a bed about 7 feet thick, whose top is 66 feet below the top of the lower Hermosa. Three limestone beds at Sandstone Mountain are somewhat lower in the section and are 1, 3, and 8 feet thick, from highest to lowest. These lower Hermosa limestones are bituminous and gray to dark gray. Marine fossils occur in the bed at Deadwood Gulch and in the middle bed at Sandstone Mountain.

Carbonized plant remains occur in a 42 -foot sandstone just below the lower dolomite bed at Deadwood Gulch; similar plant remains were found in shale at a considerably higher horizon in the Sandstone Mountain section.

The only other considerable segment of the lower Hermosa that is definitely tied to adjacent strata is the basal 94 feet exposed in the Ahkeah tunnel, as follows:

Section of basal part of lower Hermosa in Ahkeah tunnel

[ Section measured by E. T. McKnight and James Marlowe. Numbering is continuous with section on p. 14]

Lower Hermosa: Thickness
(feet)

24. Top of section is at base of porphyry sill at tunnel portal. The porphyry is faulted down to floor level at the portal.

23. Limy shale, dark-gray

22. Shaly limestone, gray; apparently a little sandy locally; has a little black chert ..-

[There is here, in tunnel, a porphyry dike about 8 ft wide, on which there is a little faulting; apparently partial thickness of unit 22 is exposed on breast side, and here repeated.]

22. Shaly limestone, gray $\left(3 \frac{1}{2} \mathrm{ft}\right)$.

21. Greenish fine-grained sandstone, shaly sandstone, sandy shale, and some gray shale, alternating and fairly well bedded

20. Green shale and sandy shale with much greenish chert

19. Fine-grained greenish sandstone and shaly sandstone, limy; typical Hermosa sandstone -..-_..- $31 / 2$

18. Shale, pale-gray $1 / 4-1 / 2$

17. Quartzite, rather large grains, light-gray, locally pulverulent ......-...- 21/4

16. Chert, pale-gray to gray, bedded; some of it is somewhat limy (less flinty); locally, some pale-gray waxy-looking limestone - 
Section of basal part of lower Hermosa in Ahkeah tunnel-Continued

Lower Hermosa-Continued

15. Dolomite, light-gray, limy; some gray to pale-gray chert in layers; a little quartzitic sandstone in basal foot

14. Shale, green, in part sandy -..--

13. Gray to pale-gray coarse-grained dolomite, porous, massive; shows some disseminated pyrite and sparse sphalerite. At $12 \frac{1}{2} \mathrm{ft}$ above base is a 1-ft green shale parting, and the dolomite for a few feet above this is greener, apparently a little more shaly, and a little better laminated; top foot of unit is crumbly quartz, apparently a replacement vein. Base conformable on Larsen Quartzite

Total exposed lower Hermosa

The thick dolomite at the base of the Hermosa here is probably of hydrothermal origin. In the Falcon mine, a thinner interval at the base of the Hermosa consists dominantly of dolomitic and shaly limestone containing crinoid stem fragments in the basal few feet. These two underground sections contain similar strata in the lower part of the Hermosa, but the strata cannot be correlated in detail, except for a gray limy chert bed (unit 16). This chert bed is $101 / 2$ feet thick in the Ahkeah tunnel, 9 feet thick in the Falcon mine, and its base is 38 and 39 feet, respectively, above the base of the Hermosa in the two sections. The other strata consist of greenish-gray sandstone (which may be arkosic), green and gray shale, shaly limestone, and one or two thin quartzitic sandstone beds. Some of these strata crop out on the right bank of Silver Creek east of the Ahkeah tunnel and also at the southwest end of Nigger Baby Hill, below the road that leads from the St. Louis tunnel to the Rico Argentine mill. Although some of the strata at the latter locality have been greatly altered by igneous metamorphism, one outcrop, which has been explored by an old prospect pit and tunnel, exposes two layers of limestone a foot or less thick and a few feet apart which have remained largely unmetamorphosed. This limestone is shaly, dark gray, and very fossiliferous. It is only a few feet below the porphyry sill that occupies the southwest end of Nigger Baby Hill and probably correlates with the shaly limestone (unit 22) cut near the portal of the Ahkeah tunnel, 72-781/2 feet above the base of the Hermosa.

Only the basal 10 feet of the Hermosa is exposed above the Leadville Limestone at the Shamrock mine. Here, it is a greenish-gray and drab to pale drab siliceous limestone containing such metamorphic minerals as tremolite and garnet, but also carrying fossil remains.

The St. Louis tunnel is driven in the lower part of the lower Hermosa for the 4,531 feet from its portal to the Blackhawk fault. In this long stretch, the strata dip obliquely toward the portal at low angles, and it would seem that the tunnel should cut through the lower part of the Hermosa to its base. However, the block of ground cut by the tunnel is broken by many small- to moderate-sized transcurrent faults, most of which drop the strata on the breastward (northeast) side. The cumulative lowering by faulting just about offsets the raising of the strata produced by dip; hence, the section of lower Hermosa revealed in the tunnel does not amount to more than about 110 feet. The zone represented is above most or all of that cut in the Ahkeah and Falcon tunnels but is not accurately tied to the rest of the stratigraphic section. It comprises dominantly sandstone, considerable shale, a little arkose, and sparse black shaly limestone in a bed that ranges from 1 foot to nearly 4 feet in thickness. Beyond the Blackhawk fault, the St. Louis tunnel and its crosscutting branches cut somewhat higher strata in the lower Hermosa, mostly sandstones and shales, but including a little shaly limestone and a fine-grained dolomite bed about 15 feet thick. The several fault blocks involved are not tied stratigraphically.

Elsewhere in the Rico district, only small outcrops involving short and uncorrelated sequences of strata are exposed in the lower Hermosa. Two small outcrops on the west bank of the Dolores River, opposite the upper end of the alluvial fan from Deadwood Gulch, are probably lower stratigraphically than the 400 feet of strata at the top of the lower Hermosa in the Deadwood Gulch section. These outcrops expose blue-gray limestones, 6 and 12 feet thick, or perhaps more, in sequences of sandstone and sandy shale. The limestones, and the shale that overlies one of them, are fossiliferous. At the upstream locality, the most conspicuous fossil is a "coquinoid aggregate of what appears to be leafy algae which resemble Eugonophyllum (Konishi and Wray)" (Lloyd G. Henbest, U.S. Geol. Survey, written commun., 1966).

Other isolated outcrops of lower Hermosa indicate that sandstones, arkoses, and shales, as previously described, dominate its composition, and thin beds of limestone or dolomite are subordinate. Cross and Spencer (1900) described a bed of gypsum locally as much as 30 feet thick, which was formerly exposed in mine workings on Newman Hill. This gyp- 
sum was bedded in black shales and thin impure limestones, and was believed by them to be about 450 feet below the top of the lower Hermosa, though the true interval now appears to be closer to 600 feet. Chemical and structural conditions produced by solution of this gypsum furnished the "contact" horizon, also called Enterprise blanket, which was richly mineralized in some of the early mines on Newman Hill. Gypsum is also reported in the interval 600-608 feet and with shaly material at the terminal depths of 742-761 feet in diamond-drill hole 3, put down vertically by the St. Louis Smelting \& Refining Co. from a drilling station in the St. Louis tunnel 310 feet east-northeast of the Black Hawk fault intersection.

From a study of the mine workings accessible on Newman Hill in the early days, Cross and Spencer (1900, p. 50-53) were able to split the lower Hermosa into stratigraphic segments whose lithology and sequence could be roughly defined by the exposures cut in the different mines. As no further information has been obtainable on this part of the section, the reader is referred to that publication for details.

Cross and Spencer (1900, p. 50) quoted the thickness of the lower Hermosa as about 800 feet, presumably on the basis of their study of the mine workings in Newman Hill. This figure is certainly too low by several hundred feet. Calculation of the stratigraphic thickness is somewhat complicated by the thick porphyry sill near the base of the Hermosa in this area. If in Pelleyre diamond-drill hole 1 the base of the Hermosa has been correctly identified, 278 feet of basal Hermosa lie below the sill. (The figure is $275 \mathrm{ft}$ in hole 2, which is $400 \mathrm{ft}$ away.) Hole 1 is about 90 feet from the Jumbo shaft which reached the top of the sill "at the bottom of the shaft" (Ransome, 1901, p. 280). In this shaft the interval from the top of the sill to the Enterprise blanket is about 515 feet (Ransome, 1901, pl. 37; see also Rickard, 1897 , p. 916,917 ). The interval from the Enterprise blanket to the top of the lower Hermosa can be approximated at two places: (1) at the Laura shaft, the depth to the Enterprise blanket (Ransome, 1901, pl. 37), when added to the interval from the shaft collar to the top of the lower Hermosa as projected from the cliffs 700 feet away, amounts to about 585 feet; (2) at the end of the Enterprise Group tunnel, the Enterprise blanket is 35 feet above the tunnel [floor?] (Ransome, 1901, p. 312), and assuming an average tunnel gradient of 2 percent, the interval from the blanket to the top of the lower Hermosa as projected from outcrop map- ping directly above is about 620 feet. ${ }^{1}$ These two approximations suggest that an estimate of 600 feet for the interval in question would not be greatly amiss. The total lower Hermosa thus amounts to about 1,400 feet. All descriptions of the ore-bearing ground in Newman Hill stress the absence of significant faults. As dips are irregular and $10^{\circ}-15^{\circ}$ at most, any corrections for dip or faulting would probably be less than the uncertainties in the above composite approximation.

MIDDLE HERMOSA

In the section on Sandstone Mountain, about 600 feet of strata are included in the middle Hermosa. Of this, 185 feet (31 percent) is limestone, including a little shaly and sandy limestone. Individual limestone units range in thickness from 1 to 33 feet and are separated by intervals of clastic strata from a few feet to 111 feet in thickness. The limestones are gray to dark gray, fossiliferous, generally fine grained, though some contain enough crinoidal and other fossil debris to become locally coarse grained. The darker ones are commonly bituminous. Some contain thin discontinuous lenses and nodules of gray to dark-gray chert at certain horizons or concentrated within thin stratigraphic intervals, but this chert is seldom conspicuous. Bedding is generally massive. None of the limestones are lithologically distinctive, and recognition of the individual beds in different areas must usually be based on the stratigraphic sequence. The $\mathrm{A}$ bed in a few places contains some rock with poorly formed oolitic texture, but its value for correlation is impaired because equally obscure oolitic texture may have been overlooked in other beds. The $\mathrm{L}$ bed, at the top of the middle Hermosa, is commonly shaly and is especially fossiliferous.

Most of the sandstones and shales are greenish gray. Some of the shales grade to almost black; a few of them, however, grade locally to brownish red, though this color has no stratigraphic persistence. Reddish tints are also present in certain thin shaly limestone zones.

In the mine workings that penetrate $\mathrm{CHC}$ Hill, across the Dolores River from Sandstone Mountain, the limestone units of the middle Hermosa are not greatly changed. The clastic strata between the limestone beds, however, lack any constancy in lithologic character or thickness. The sequence is downfaulted on the southeast by the Princeton fault.

Where the strata reappear in the mine workings on Silver Creek, the Sandstone Mountain section is

\footnotetext{
${ }^{1}$ The interval would be increased or decreased as the true tunnel gradient, not now known, is less or greater than 2 percent at a rate of $30 \mathrm{ft}$ for each unit difference from 2 percent.
} 
still recognizable in the limestone sequence, though there has been some change. The limestone beds are, for the most part, slightly thicker. Two limestone beds, I and J, have coalesced through disappearance of the parting sandstone between them, although at one place (113 crosscut on Blaine level) the resultant composite unit contains, above its middle, a very limy black shale parting, 5 feet thick. The coalesced unit is somewhat thicker than either I or $\mathrm{J}$ bed, but the total thickness of limestone in this interval is less. The middle Hermosa in the workings of the Rico Argentine mine up Silver Creek totals about 610 feet in thickness, of which 188 feet (30 percent) is limestone.

Because an understanding of the limestone sequence should be of economic value in developing mineralized ground in the Silver Creek area, an abbreviated composite section for this area is given below. This has been compounded from exposures on the St. Louis, 400, 300, 200, Blaine, Argentine, and Log Cabin levels. Faulting has been extensive in the mine workings available for examination, and the presence of many porphyry dikes and sills has further complicated the sequence; hence, many blocks of ground have had to be considered and correlated in arriving at the composite section. Considerable judgment has been necessary in weighting or averaging thicknesses, and some intervals of the section can be only approximations. However, the sequence and general magnitude of thicknesses are believed to be correct, though the clastic strata are subject to lateral variation. Correlation of the limestone beds with the Sandstone Mountain section is shown, and the designations used by mining company geologists for these beds have been added in parentheses.

Composite section of middle and part of upper Hermosa Formation in Rico Argentine mine workings on Silver Creek (Log Cabin to St. Louis levels)

Upper Hermosa:

30. Sandstone and arkose, 1 -ft shale partings_-

29. Limestone ( 6 bed of mining company geologists), somewhat shaly

28. Green shale and sandy shale, part limy; some sandstone -

27. Limestone (5 bed), dark-gray, shaly, cri-

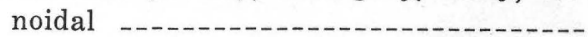

26. At base, black very limy shale zone, $0-12$ $\mathrm{ft}$ thick, in one place has 6 -in. Fusulina zone $4 \mathrm{ft}$ above base; grades up to dense gray shaly limestone with dark shaly cleavages and partings, and gray and greenish to almost black very limy shale, some slightly sandy; more shaly in upper half, except some sandstone in

Thickness
$($ feet $)$

$30+$

15

$67 \pm$

9
Composite section of middle and part of upper Hermosa Formation in Rico Argentine mine workings on Silver Creek (Log Cabin to St. Louis levels)-Continued

Upper Hermosa-Continued

Thickness (feet)

top $15 \mathrm{ft}$. St. Louis tunnel section has abundant small crinoid stem fragments, maximum $1 / 10$ in. in diameter, in shales of upper half, locally concentrating to 1-ft zones of largely crinoidal material. Unit is massive to thin bedded

Middle Hermosa:

25. $\mathrm{L}$ bed limestone (4 bed), fine-grained, crinoidal, shaly, with black paper-thin shale partings or black limy shale partings as much as $4 \mathrm{ft}$ thick; very fossiliferous, some crinoid stem fragments to nearly 1 in. in diameter; locally has some gray chert. Thickness variable because of gradational upper contact_---

24. Sandstone (especially in lower part), sandy shale, and shale; partly limy, some limestone nodules in the shales; locally, some reddish micaceous fine-grained sandstone

23. Green shale

22. $\mathrm{K}$ bed limestone ( 3 bed), dark-gray, partly shaly

21. Arkose and sandstone, a few shale partings in places as much as $5 \mathrm{ft}$ thick

20. I-J bed limestone ( 2 bed), gray. In one section (113 crosscut on Blaine), a 5 -ft zone, starting $4 \mathrm{ft}$ below top, is black, very limy shale, and lower limestone is $8 \mathrm{ft}$ thick

19. Sandstone, green, partly limy and shaly --

18. Limy shale, green and gray to black; locally, a little sandy shale; locally, some redbrown nonlimy shale. Has 2- to 4-ft shaly limestone zone with Fusulina about $8 \mathrm{ft}$ below top

17. $\mathrm{H}$ bed limestone ( $\mathrm{A}$ bed $=1$ bed), darkgray, rather thin bedded, crinoid stem fragments as much as $3 / 4$ or $1 \mathrm{in}$. but not in top $2 \mathrm{ft}$

16. Green to black shale or sandstone with some arkose

15. Sandstone or arkose

14. Shale, gray or green to black; some sandy

13. Sandstone; some arkose -...-...-..--

12. Shale, gray to green, siliceous, massive --

11. E bed limestone (B bed=zero bed), darkgray, somewhat shaly, thin-bedded -.--

10. Green and gray shale, sandy shale, and sandstone; distribution and proportions vary in different sections _......-..-

9. D bed limestone (C bed), gray -...-..-

8. Shale, gray and green to black

7. Arkose and sandstone, massive -.......-

6. Shale, gray and green to black; locally, some reddish 
Composite section of middle and part of upper Hermosa Formation in Rico Argentine mine workings on Silver Creek (Log Cabin to St. Louis levels)-Continued

Middle Hermosa-Continued

5. C bed limestone ( $\mathrm{D}$ bed), in part dolomite; somewhat shaly, especially at top

4. Dark-green shale (4 ft) at base, somewhat sandy; grades up to shaly sandstone and fine-grained sandstone with a few shale partings; dominantly sandstone toward top -...-

3. B bed limestone, dark-gray, shaly -..--

2. Arkose, sandstone, minor shale partings; full thickness not exposed, may be $50 \mathrm{ft}$

1. A bed limestone; thickness is a guess -.-

Total middle Hermosa Thickness
(feet) 25 4

$\begin{array}{r}27+ \\ 20 \pm \\ \hline 611 \pm\end{array}$

Aside from the limestones, little in this section can be correlated directly with the Sandstone Mountain exposures. However, the thick shale and overlying sandstone unit between $\mathrm{H}$ and I-J limestones, and the thick arkose and sandstone above I-J limestone, are common to the two sections and strengthen the correlations. The basal 126 feet of the upper Hermosa is also distinctive.

A pronounced change in the character of the middle Hermosa takes place between the Rico Argentine mine workings on Silver Creek and the cliffs above Newman Hill, a mile to the southwest. Although lack of exposures in the lower part of the section at the latter locality prevents an unequivocal demonstration of what has taken place, the change is best explained as a disappearance of the clastic strata between the limestone beds and particularly between the upper ones, allowing them to coalesce into much thicker units. In this process, the overall thickness of the middle Hermosa is reduced to less than half, though the total thickness of limestone remains about the same. Thus, a composite section indicates a total thickness of only 275 feet for the middle Hermosa, of which 188 feet (68 percent) is limestone. Most of this limestone is concentrated at the top-including the upper 105 feet, and below an underlying 36-foot interval of limy sandstone, 41 more feet of limestone. Very thin partings that break the cliffs of these thicker limestone sequences into two or three units may each represent hiatuses in limestone deposition which are occupied by clastic strata farther northeast. There are two lower limestone beds, including the basal one, which more nearly resemble those of Sandstone Mountain in thickness and intercalations of clastic strata. The following two sections form a composite of two localities.
Partial section of Hermosa Formation exposed above Newman Hill, on spur south of gulch at Laura shaft

[Section measured by E. T. McKnight and Robert C. Pearson. Higher strata are exposed but are not described here]

Thickness
(feet)

Middle Hermosa:

14. At base, a few inches of green limy shale or shaly limestone, then 8 in. of limestone, then greenish limy sandstone that weathers gnarly; a sandy limestone zone, only $1 \mathrm{ft}$ exposed, has base about $8 \mathrm{ft}$ above base of unit. (This is unit 14 of the following section.)

13. Limestone, gray; massive but thinner bedded in top $5 \mathrm{ft}$

12. Arkose, greenish, crossbedded; some layers contain quartz and feldspar fragments as large as $1 / 4$ in., or rounded and angular pebbles as large as $1 \mathrm{in}$; finer grained at top -

11. Sandstone, fine-grained, greenish, thin-

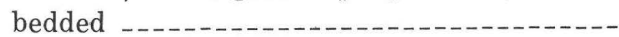

10. Concealed -

9. Limestone, gray and blue, slabby; not particularly fossiliferous but has a few $3 / 4$ in. crinoid stem fragments in basal few feet; has chert nodules irregularly distributed, as much as 2 in. thick and $1 \mathrm{ft}$ long; sandy in basal $2 \mathrm{ft}$, gradational from underlying

Lower Hermosa:

8. Sandstone, greenish, thin-bedded, some a little limy; somewhat shaly at base with 1 or $2 \mathrm{ft}$ of dark-gray sandy shale there -...-

7. Limestone, dark-gray, muddy; purer in top foot

6. Sandstone, greenish, massive -...-_-_-_-

5. Limy sandstone, greenish, thin-bedded --.-

4. Concealed -...-.

3. Limy sandstone, greenish; a 1-ft harder

ledge at top
2. Limestone, blue-gray; basal 8 in. in ledge, rest nodular

1. Limy shale and shaly limestone, bedded 13 in.

[Section ends at lowest exposures.]

Total exposed lower Hermosa

Partial section of Hermosa Formation exposed above Newman Hill, $1 / 4$ mile northeast of preceding section, on spur just south of big snowslide area pointing into Rico

[Section measured by E. T. McKnight and Robert C. Pearson. Numbering of correlated units is same as in preceding section. Top of section east of (uphill from) the fault]

Thickness
(feet)

Upper Hermosa:

29. Limestone, dark-blue-gray, fossiliferous (abundant Fusulina); forms ledge...--

28. Shaly limestone and limy shale, gray, thin-bedded; grades to sandy limestone and limy sandstone in a few comparatively thin zones; unit is typical of this unit elsewhere 
Partial section of Hermosa Formation exposed above Newman Hill, $1 / 4$ mile northeast of preceding section, on spur just south of big snow slide area pointing into Rico-Continued

Upper Hermosa-Continued

27. Concealed (but undoubtedly like overlying unit)

26. Limestone, bluish-gray, highly fossiliferous, rather thin bedded; contains scattered nodules of dark-gray chert in upper half

25. Shaly limestone and limy shale, gray, thinbedded; like the basal unit of upper Hermosa elsewhere; sandy in 1 thin ledge.-

24. Limestone, bluish-g r a y, fossiliferous; grades to underlying unit

23. Sandstone, fine-grained, micaceous, thinbedded, alternating greenish and reddish; a reddish very limy zone $1 \mathrm{ft}$ thick, about $6 \mathrm{ft}$ above base

22. Concealed -...-...-

21. Greenish crossbedded arkose (not particularly coarse) and sandstone

20. L bed limestone, dark-gray, nodular, very fossiliferous (some Fusulina beds); bedded 1-12 in. In a zone about $2 \mathrm{ft}$ thick whose base is $17 \mathrm{ft}$ above base of unit are scattered nodules of gray chert, many more or less equidimensional; in $2 \frac{1 / 2}{\mathrm{ft}}$ zone whose base is $30 \mathrm{ft}$ above base of unit is a little gray to whitish chert in thin streaks along bedding

19. Limestone, gray, fossiliferous; massive below, somewhat more bedded toward top --

18. Limestone, dark-gray, very fossiliferous (some layers with abundant Fusulina); rather thinner bedded (3-6 in.) than average; mostly weathers to steep talus slope --

17. Mostly limy sandstone, green, crossbedded; weathers to ledge outcrop. Grades to limestone in $1 \frac{1 / 2}{-} \mathrm{ft}$ zone with base $8 \mathrm{ft}$ above base of unit; this limestone is overlain by $2 \mathrm{ft}$ of greenish sandy shale, above which the unit is more consistently fairly coarse grained sandstone, arkosic in large part except at top

16. Limestone, gray, fossiliferous, massive; Chaetetes-type coral in top $3 \mathrm{ft}$; zone of chert nodules, about 2 in. thick, is 3 $\mathrm{ft}$ above base -...-.

15. Limestone, gray, fossiliferous, distinctly bedded. Zone 8 in. below top has gray chert nodules 2 in. thick, $2 \mathrm{ft}$ long. Very coarse crinoid stem fragments $(3 / 4$ in. diameter) in zone 3-5 $\mathrm{ft}$ below top ----

14. Mostly limy sandstone, finely micaceous, greenish, thin-bedded. Basal few inches is greenish limy shale; a 6 -in. bed of limestone has base $1 \mathrm{ft}$ above base of unit, and unit grades to nodular, in part sandy limestone in zone 2-4 ft below top ----

13. Gray limestone, fossiliferous, sandy in basal foot, massive. At $4 \frac{1}{2} \mathrm{ft}$ below top is a

Thickness

$$
12
$$

Partial section of Hermosa Formation exposed above Newman Hill, $1 / 4$ mile northeast of preceding section, on spur just south of big snow slide area pointing into Rico-Continued

\section{Middle Hermosa-Continued}

\section{Thickness
(feet)}

gray chert zone as much as 3 in. thick, with very rough irregular top and bottom boundaries; limestone above this chert is thinner bedded

12. At base, coarse arkose, crossbedded, with quartz pebbles and scattered chert pebbles as large as 1 in.; grades to greenish sandstone at top

11b. Limy shale, finely micaceous, greenish, laminated -...-...-...--

11a. Shaly sandstone, micaceous, greenish

[Section ends at lowest exposures on the spur.]

$$
\text { Total exposed middle Hermosa }
$$$$
\text { (composite of two sections) - } 275
$$

Although conceivably the strata below unit 9 could be equivalent to the lower part of the middle Hermosa on Sandstone Mountain from which one or more limestone beds have pinched out, it seems more probable that the lower Hermosa is represented. This surmise is strengthened by the mapping in Deadwood Gulch where more of the section below the thick limestones is exposed. Although the middle Hermosa was not measured here, the mapping indicates a thickness of only 250-320 feet, and the limestone at the base of this thickness locally contains poorly developed oolitic texture, suggesting the A bed of the Sandstone Mountain area.

A key horizon recognizable through much of the Newman Hill-Deadwood Gulch area occurs in the limestone of unit 16. The uppermost 3 feet of this unit contains a Chaetetes type of colonial coral which is common enough to be readily found in most sections. This coral has not been observed in the Sandstone Mountain section, though it may have been overlooked. Its recognition there would greatly aid the stratigraphic correlation between the two dissimilar sections.

UPPER HERMOSA

The composite section for the Sandstone Mountain area shows 830 feet of strata in the upper Hermosa, consisting of arkose, sandstone, shale, conglomerate, and a little limestone in thin beds. Most of the carbonate material, however, occurs as a common impurity or admixture in the sandstones and shales. The conglomerates occur only in the upper half and chiefly in the upper 350 feet. Some carbonate-bearing beds occur in that part of the section that contains the conglomerates, but they are more abundant in the lower lying strata. Although the rock colors are 
similar to those in the middle Hermosa, the brownish-red phases, expressed as purplish gray in the arkoses, become more conspicuous, especially toward the top of the Hermosa.

With a few exceptions, the upper Hermosa is, in general, characterized by lack of lateral persistence in individual beds and by widely varying proportions of the different rock types from place to place. A distinctive lithologic facies occurs at or near its base. This facies is a thinly laminated gray marlstone sequence, varying from limy shale and limy fine-grained sandstone to shaly and sandy limestone. In the Sandstone Mountain section its thickness is 118 feet (units 59-61), and it contains some carbonized plant stem fossils. At outcrops about 200 feet northeast of the Logan tunnel in CHC Hill, one horizon in the unit contains casts of gypsum crystals in shaly limestone. The facies is easily recognizable underground, as, for example, on the St. Louis tunnel level, between 590 and 810 feet (measured along the tunnel) northwest of the Argentine shaft (projected). Here, the upper half contains abundant fragments of small crinoid stems, one-tenth inch in diameter, which become concentrated in a few seams, as much as 1 foot thick, consisting almost entirely of such fragments. In the section above Newman Hill, the zone is about 132 feet thick (units 24-28) but is separated from the underlying middle Hermosa by 59 feet of sandstone and arkose. Parts of the Newman Hill and Deadwood Gulch exposures are extremely limy, resembling. some of the thick limestone sequences of the middle Hermosa. These purer limestone phases may contain some dark-gray chert and may be highly fossiliferous.

The marlstone sequence is overlain by a limestone bed that varies in thickness laterally. It is only $31 / 2$ feet thick (unit 62) in Sandstone Mountain and at the CVG mine on the east side of the Dolores River at Burns, but it is 9 feet thick at one locality on the west side of the river at Burns and shows a similar thickness in the workings of the Rico Consolidated mine on Silver Creek where it forms the chief ore bed. An intermediate thickness is present on the north slope of Silver Creek above the Yellow Jacket workings. The unit was not positively recognized in the exposures above Newman Hill, but it is probably represented by a blue-gray fossiliferous limestone bed only 8 inches thick (unit 29 of the section).

Other thin limestone beds are present in the upper Hermosa, but either they lack continuity, or their correlation from place to place is equivocal. A 7-foot fossiliferous and slightly sandy limestone in the bed of Deadwood Gulch probably correlates with a 9-foot sandy limestone at 236 feet above the base of the upper Hermosa in the section above Newman Hill, but no comparable stratum is recognized at the same horizon on Sandstone Mountain. Other thin limestones are commonly shaly or nodular, and such types may be brownish red in part.

A thick black shale (unit 80, Sandstone Mountain), with thin fossiliferous limestone seams at and near its base, is 320 feet above the base of the upper Hermosa on Sandstone Mountain and 325 feet above the base in the exposures above Newman Hill. The shale is poorly exposed at the latter locality but is evidently a stratigraphically persistent unit in the Rico district. It was cut in the south crosscut of the St. Louis tunnel between 1,380 and 1,640 feet (measured along the tunnel) northwest from the Argentine shaft.

Measurements and compilation of a composite section of upper Hermosa above Newman Hill indicate a thickness here of about 717 feet. Because of poor exposures and the possibility of hidden faults in addition to the considerable number recognized, this thickness may not be so reliable as that measured on Sandstone Mountain. The suggested thinning of the upper Hermosa, if real, apparently comes mostly in the upper conglomerate-bearing part of the section, which above Newman Hill is only 230 feet thick. The thickness of strata below the lowest significant conglomerate is nearly the same in the two sections, but the conglomeratic material lacks continuity and contrast with lower coarse arkoses that would make it useful in defining stratigraphic horizons.

During the late Paleozoic, the environment of deposition changed in the Rico area from marine deposition in the middle Hermosa to continental sedimentation during deposition of the Cutler Formation. The change was gradual, and no sharp break can be recognized in the sedimentary record. Although the coarser arkoses and conglomerates of the upper Hermosa may have been deposited in marine waters, they indicate a proximity to a land of considerable topographic relief, and thus are an early manifestation of the change to continental sedimentation. Intercalation of fossil-bearing marine strata persisted well up in the series of coarser clastic material, but became less common as time progressed. The sedimentary record left by one of these late marine incursions is herein chosen to mark the top of the Hermosa Formation. The stratum is a shaly limestone, locally sandy, and a foot or less thick, generally characterized by an abundance of fusulinid remains. Although it is an insignificant lithologic unit, it has the advantage of 
lateral persistence and of marking a definite stratigraphic horizon in an otherwise undivided sedimentary sequence; its appearance in outcrop and its position relative to adjacent strata are such that it is not hard to find. The unit weathers generally to a rounded ledge, characteristically brown, and it occurs 10-25 feet below the top of a greenish limy or sandy finely micaceous shale. In some sections it is underlain by similar shales, but in other sections it is underlain by sandy or arkosic material, and thus lies at the base of the shale. Doubtless, these shales are of marine origin and were considered by Cross and Spencer (1900) to be the uppermost Hermosa. Because of their variable thickness and gradational upper boundary, it seems more practical for mapping to lower the top of the Hermosa to the Fusulina bed. A thin ledge resembling the Fusulina bed and occurring in a similar shale setting lies 130 feet below the top of the Hermosa in the outcrops above Newman Hill, but this bed lacks the Fusulina, though it carries other small fossils. Fusulina is, however, a common fossil at several lower levels in the Hermosa.

AGE AND STRATIGRAPHIC RELATIONS

Many of the Hermosa strata, but particularly the limestones and limy shales, contain a marine invertebrate fauna of Middle Pennsylvanian age.

At the Shamrock mine locality where the Hermosa rests on the Leadville Limestone, exposures are too poor to reveal the nature of the contact. However, it is undoubtedly an unconformity, for there is a pronounced hitaus revealed elsewhere in the San Juan region by an erosional unconformity at the base of the Pennsylvanian strata.

The Hermosa is conformable on the Larsen Quartzite and is conformably overlain by the Rico Formation.

MIDDLE AND UPPER (?) PENNSYLVANIAN SERIES RICO FORMATION

GENERAL FEATURES, DISTRIBUTION, AND THICKNESS

The Rico Formation is a transitional unit between marine Hermosa strata below and continental Cutler strata above. It is composed predominantly of thick-bedded coarse clastic material and subordinate shale and impure limestone. Many of the shales are red, and the arenaceous beds commonly have a purple or red tinge. Some of the sandstones are very limy and contain marine fossils, particularly pelecypods and gastropods.

Most outcrops of the Rico Formation are high on the mountain slopes overlooking the town of Rico, but the dips away from the Rico dome bring the formation down to stream level on Silver Creek at the east edge of the area shown on plate 1 and on the Dolores River a short distance beyond the north limits of this area. The outcrop band, broken and offset by many faults, extends from the ridgetop south of Deadwood Gulch in a general northeasterly direction across the west slope of Dolores Mountain, descending eventually to the Silver Creek crossing. It then rises in a general westerly direction to high on the spur at the southwest end of Nigger Baby Hill. The formation is concealed by wash, talus, and landslide debris in CHC Hill. In the cliffs northeast of CHC Hill it reappears in the footwall of the Princeton fault, descends northwestward to the Dolores River crossing, and thence rises southwest to a crossing of the higher part of the ridge above Sandstone Mountain.

Outcrops of the Rico are generally poor, but several detailed measurements of sections have been made. The thickness is 259 feet on the ridge northwest of Sandstone Mountain; 277 feet on the west side of Dolores River, 0.2 mile upstream from Marguerite Draw (just north of area shown on plate 1) ; 275 feet in a section 800 feet north of Strawberry Spring above CHC Hill; and 324 feet on the north side of Silver Creek, on the first spur southwest of the Black Hawk fault. Cross and Spencer (1900) describe 237 feet of strata in their type section up Scotch Creek, 3 miles south of town. The base of their section, however, is an unspecified interval above the Fusulina bed, which in the present report is designated as the top of the Hermosa, and the top of their section is overlain by poorly exposed strata. In mapping the Rico mining district, they used a thickness of 325 feet to extrapolate the upper boundary from the better exposed lower boundary in those places where the upper boundary was concealed. As the base of their Rico was defined on the occurrence of fossils that cannot always be found at the appropriate horizon, the boundary has been adjusted downward in the present report to include an additional 25-35 feet of strata formerly included in the Hermosa above the Fusulina bed. Thus, Cross and Spencer indicate a somewhat greater thickness of Rico within the mining district than was found during the fieldwork for the present report.

\section{LITHOLOGIC CHARACTER}

The Rico Formation is predominantly sandstone and arkose, in part conglomeratic, with subordinate shale and shaly limestone. Cross and Spencer (1900) have published a detailed description of the type section on Scotch Creek. The following is another typical section. 
Section of Rico Formation, 800 feet north of Strawberry Spring above CHC Hill

[Section measured by E. T. McKnight and James C. Ratté] Thickness

Cutler Formation:

21. Limy micaceous shale or fine-grained sandstone, maroon, a little greenish; has limestone nodules near base and top. Lower

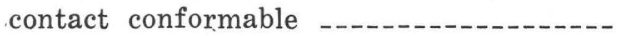

Rico Formation:

20. Limy sandstone, greenish; a 2-ft maroon micaceous shale parting has its base $14 \mathrm{ft}$ above base of unit

19. Greenish limy sandstone in thin beds (1-2 $\mathrm{ft}$, lenticular), maroon shale, greenish shale, olive-green shale; pelecypods in a 3 -in. sandy limestone $7 \mathrm{ft}$ above base; 15 in. higher, gastropods occur in a purplish limy sandstone

18. Limy sandstone, greenish, thin-bedded; fossil pelecypods about $3 \mathrm{ft}$ above base -...--

17. Arkose, pale, massive; contains scattered pebbles as large as $1 \mathrm{in}$., in places as large as 2 in., and feldspar fragments as large as $1 / 2$ in.

16. Gray earthy nodular limestone, some greenish limy shale, a little maroon shale in thin bands

15. Sandstone, greenish, micaceous

14. Arkose, pale, massive; contains scattered pebbles as large as $1 \mathrm{in}$. in basal $5 \mathrm{ft}$, and as large as $2 \mathrm{in}$. in next $5 \mathrm{ft}$

13. Shale, finely micaceous, maroon; contains some maroon limy nodules; some interbedded greenish shale, especially in basal 2 $\mathrm{ft}$, and a discontinuous lens of sandstone, $1 \mathrm{ft}$ thick, near base

12. Sandstone, gradation from underlying unit; thin bedded

11. Arkose, pale-greenish to pale-flesh, massive; locally contains pebbles as large as $1 / 2$ in. - c.-.-.-.-

10. Basal $4 \mathrm{ft}$ is gray nodular earthy limestone (weathering brown), with fairly solid limestone in basal foot; rest is olive-green shale, a little reddish toward top -..--.--

9. Shale, finely micaceous, maroon and greenish gray; contains limestone nodules especially in basal $5 \mathrm{ft}$ but scattered

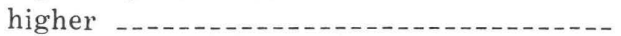

8. Arkose, greenish; contains scattered pebbles as large as $1 \mathrm{in}$.

7. Basal foot is very limy gray nodular sandstone, then limy greenish finely nodular shale, becoming locally reddish in top $1 \frac{1}{2}$ $\mathrm{ft}$

6. Arkose, pale-flesh, massive; contains scattered pebbles as large as 1 in. (uncommonly as large as 2 in.), partly in bedding seams

5. Lower half, maroon shale; upper half, sandstone like unit 4 but not quite so limy; has some fossils
Section of Rico Formation, 800 feet north of Strawberry Spring above $\mathrm{CHC}$ Hill-Continued

Thickness

Rico Formation-Continued

4. Sandy limestone or limy sandstone, olive, weathering brown; loaded with calcitic cross sections of pelecypods -.--_-_---

3. Limy sandstone, greenish with purplish tinge locally; laterally not separable from unit

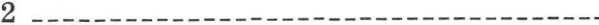

2. Shaly sandstone and sandy shale, maroon; becoming locally greenish

1. Sandy shale, dark-gray to blackish in basal 6 $\mathrm{ft}$, grades up to green micaceous sandy shale, becoming green shaly sandstone in top $2 \mathrm{ft}$; contains fossils (brachipods, pelecypods, etc.) in basal foot -..--- $181 / 2$

Total Rico Formation

Upper Hermosa Formation:

Fusulina bed: Sandy limestone, dark-gray, weathers brown; has abundant fossils (crinoid stem fragments, brachiopods, Fusulina, etc.) ; occurs about $4 \mathrm{ft}$ below top of pinnacle

The arenaceous beds are greenish gray and flesh colored to purplish gray or, less commonly, reddish, and their color varies not only from bed to bed, but also laterally. Fragments of feldspar are an abundant constituent, and muscovite is common. Many of the sandstones, including the red ones, are very limy, and a characteristic feature is the occurrence in these sandstones of thick pelecypod or gastropod shells whose cross sections are conspicuous on the weathered surfaces. The arkoses are generally crossbedded. Pebbles in the conglomeratic layers are rounded to angular and do not exceed 2 inches in diameter. They are composed of argillite, quartzite, limestone, quartz, pink granite, and perhaps other rock types. The more massive beds are as much as 30 feet thick.

The shales are generally limy or sandy and finely micaceous. They are commonly red or maroon, but some are greenish gray. The limestones are shaly or sandy and thin. A few are gray and contain marine fossils. The most common limestones, however, are of a different type. These are commonly gnarly and gradational into shales. Although some are red, purple, or maroon, the more limy phases tend to be gray or green, and in the more gnarly phases the colors may be mottled. These earthy limestones are unfossiliferous and of a type that is common in the overlying nonmarine strata comprising the Cutler Formation.

Although the Rico Formation is usually pictured as a red-bed formation that is hard to distinguish from the Cutler, in reality it is generally not very ${ }_{11 / 2}$ red in this, its type locality. It is very similar to the 
upper conglomeratic part of the upper Hermosa in its stratigraphic makeup and color. Prevalence of thick sandstones and arkoses gives a massiveness to the overall outcrop that is lacking in the Cutler, which contains a higher proportion of shaly red beds.

Lateral variation is characteristic of the Rico, and individual strata cannot, in general, be correlated between adjacent sections. Two of the green shales, however, show some persistence laterally. These are marine shales, for they either contain fossils or are closely overlain or underlain by fossilbearing strata. The green shale at the base, just above the Fusulina bed that marks the top of the Hermosa, is present in most sections, though its thickness varies from 10 to 25 feet. It commonly contains fragments of crinoid stems. A similar shale, though without crinoids, near the top of the Rico in the section north of Strawberry Spring (unit 19 of the detailed section) is also recognizable on the west side of the Dolores River, 11/4 miles to the northwest, and also on the ridge above Sandstone Mountain, 11/4 miles to the west, but is not specifically recognizable in a much thicker shale-bearing interval on the north side of Silver Creek, 1 mile to the south. Cross and Spencer (1900) have emphasized the persistence of a fossiliferous limy sandstone bed whose base is 30-35 (locally 40 ) feet above the Fusulina bed. Although this bed has not been found at the appropriate horizon at every place in the district, it is present at enough places to constitute a valuable horizon marker.

STRATIGRAPHIC RELATIONS AND AGE

The Rico Formation conformably overlies the marine Hermosa Formation. Although some of the gnarly limestones of the Rico are of a type that is characteristic of continental sedimentation and may actually represent incursions of continental conditions, the fossils that occur at several horizons to the top of the formation indicate that marine conditions prevailed, or at least recurred, until the end of Rico deposition. The formation is overlain conformably by the continental Cutler Formation. The top of the Rico was originally defined (Cross and Spencer, 1900) on the highest occurrence of marine fossils, but it is equally definable on a lithologic basis, namely, the prevalence of thick massive sandy strata. The top is gradational on the basis of either of these criteria, and may not always be placed at exactly the same stratigraphic horizon. In the detailed section near Strawberry Spring, a limy sandstone bed, 24 feet thick, that caps the dominantly sandstone sequence forming a cliffy outcrop, is classed as the top of the Rico. The highest fossils are in the immediately underlying beds.

Strata that have been called Rico in Colorado and Utah range in age from Middle Pennsylvanian to Permian. For this type area, the invertebrate fossils indicate a Middle Pennsylvanian age (L. G. Henbest, written commun., 1955), but Upper Pennsylvanian strata may also be included, for no hiatus has been recognized in the stratigraphic succession from the Rico to the overlying Cutler which is of Early Permian age. The most abundant fossil types found in the Rico constitute a facies fauna dominated by pelecypods and gastropods. Correlation of this fauna has been somewhat equivocal in the past, and it was considered by G. H. Girty to be a transitional fauna between the Pennsylvanian and Permian.

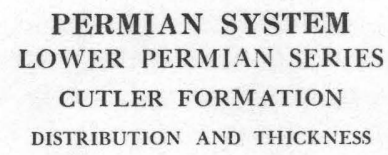

The Cutler Formation is a thick continental redbed series whose outcrops completely surround the structural dome centered in the Rico district. The formation caps most of the high peaks and ridges within the district. Except for Quaternary surficial deposits, it is the youngest sedimentary formation exposed within the area studied, but only an incomplete section is present. As the formation lacks horizon markers that would permit it to be studied and measured in parts and as the exposures are separated by wide stretches that could conceal faults, no estimate of thickness based on composite sections has been attempted. The total thickness exposed from the slope above Silver Creek to the top of Telescope Mountain may approximate 2,800 feet, if an average dip of $10^{\circ}$ and no significant faulting can be assumed. A composite section measured by W. P. Pratt on the west side of the Dolores River just north of the area shown on plate 1 amounts to about 2,100 feet.

$$
\text { LITHOLOGIC CHARACTER }
$$

The Cutler Formation consists of interbedded shale, arkose, conglomerate, sandstone, and impure limestone, in which red colors are conspicuous.

The arkoses are crossbedded, greenish gray and flesh colored to purplish, and grade to coarse conglomerate in which rounded cobbles as much as 6 inches in diameter are present. The cobbles include several rock types-quartz, gray and reddish quartzite, pink granite, pink pegmatite, pink dacite, gray argillite, and limestone. Shale pellets from erosion of penecontemporaneous sediments are common. The matrix of the conglomerates is a coarse grit of 
angular quartz grains but also includes large fragments of flesh-colored orthoclase. Sandstones are less abundant, in part greenish but more commonly purple or red.

Shales, which are generally sandy or limy and micaceous, form a considerally higher proportion of the Cutler Formation than of the Rico. Prevalence of red colors is due largely to them. The common color is a vermilion red or maroon, even more widespread than the relative abundance of shale would suggest, for the fine clayey sediment from disintegration of the shale has commonly washed down on the outcrops and surficially permeated coarser strata not intrinsically red. Locally, green micaceous shale may be intercalated with the red shale or arkose.

The limestone, which is in scattered thin beds, is an earthy nodular type, intimately intermixed with, and grading into, shales. Red and purple phases are common, but the limier phases are likely to be gray or green. These limestone zones are unfossiliferous and discontinuous, evidently representing deposits in ephemeral and shifting bodies of water under conditions of continental deposition.

Most bedding surfaces in the maroon shale have a satiny sheen, owing to the layering of fine mica scales parallel to the bedding. On such bedding surfaces, worm borings are common and very conspicuous because the mica scales in the material filling the tubes have acquired random orientation and thus do not reflect the sheen. Except for the disordered orientation or rare vaguely concentric structure, the material inside the tubes is identical with that in the undisturbed rock. Most borings show as rounded cross sections, a quarter of an inch or less in diameter, on the bedding surfaces, and fractures across the bedding reveal the borings crosscutting the shale layers. A certain number, however, wander irregularly along the bedding. Some disturbed patches on bedding surfaces are larger than the usual track, irregular in shape, and have borders compounded of many intersecting, but unevenly spaced, scallops of about the same radius of curvature as seen in the simpler worm borings. These suggest places where a considerable volume of sediment was worked over by the organism responsible for the simple borings.

In some blocks of ground that have been subjected to the pervasive chemical action of hydrothermal solutions, the Cutler Formation has lost its red color and is greenish gray throughout. One such area showing on the surface above CHC Hill, just northeast of the prospect tunnel at an altitude of 10,788 feet, is in the hanging wall of the Blackhawk fault, 2,000 feet vertically above, and 500 feet north of, the end of the St. Louis adit. Doubtless a considerably larger area than that exposed is involved, but the adjacent surface to the west, overlying the Mountain Spring and Wellington mines, is covered by landslide debris. Cross and Spencer (1900) mapped the bleached block as Hermosa, surrounded on all sides by landslide debris. Although the exposures in the slope east of the block are poor, the green strata grade into stratigraphically higher red strata of typical Cutler. Furthermore, the underground work since 1930 has indicated no deep structure that could account for an upraised block of Hermosa, but, rather, has further defined the Princeton fault which has depressed the block of ground in question.

STRATIGRAPHIC RELATIONS AND AGE.

The Cutler Formation is conformable on the Rico Formation, and represents the final ascendance of continental over marine conditions of sedimentation.

A vertebrate fauna found in the interval 80-885 feet below the top of a 4,000-foot Cutler section near Placerville, 21 miles north of Rico, is classed as Early Permian in age (Lewis and Vaughn, 1965). Basal Cutler strata at Rico are at least several hundred feet lower stratigraphically than the fossil beds at Placerville and might conceivably be somewhat older than Early Permian. However, vertebrate fossils of essentially the same Early Permian age (Vaughn, 1962) have been found near Mexican Hat in southeast Utah at a horizon in the lower Cutler, perhaps 2,000 feet below the top of the Cutler in that region. This at least suggests that all of the Cutler may be no older than Early Permian at Rico.

\section{QUATERNARY SYSTEM \\ HOLOCENE SERIES \\ SURFICIAL DEPOSITS}

Surficial deposits of the district comprise (1) alluvium and stream gravels, (2) torrential fans, (3) talus and slope wash, (4) landslide deposits, and (5) calcareous tufa. Classification and mapping of these deposits received special attention during the geologic investigations of Cross and Spencer (1900), and their map delineation of these features has been in large part followed on plate 1, though some modification has been made in certain details.

Alluvium and stream gravels.-These deposits are confined to the valley of the Dolores River, and in view of their location near the headwaters of the river, they are rather coarse in texture. Continuity in their extent along the river has been interrupted south of Burns by the landslide off $\mathrm{CHC}$ Hill, through which the river is still actively downcutting. 
The alluvial plain is elsewhere narrowed by encroachment of torrential fan debris at the mouths of certain large tributaries.

Torrential fans.-The mouths of such drainage tributaries as Horse Creek, Aztec Gulch, Silver Creek, and Deadwood Gulch are marked by extensive detrital fans. Although the fan at the mouth of Silver Creek was not recognized as such in the mapping by Cross and Spencer (1900), pl. 22), certainly much of the concealing debris on the townsite is fan debris. However, the fan deposit is not so continuous here as in the other areas mentioned.

Talus and slope wash.-Extensive debris mantles the lower slopes in the Rico district, to such an extent that much of the bedrock geology is obscured. The forest and other forms of vegetation aid in holding the debris in place, and the high annual precipitation insures adequate moisture for deep weathering. In places, the surficial cover is very thick. Thus, on Newman Hill where adequate opportunities were available during the days of active mining to determine the thickness of the debris cover, the maximum thickness was reported to be 300-400 feet (Rickard, 1897, p. 913; Ransome, 1901, p. 312). In general, if enough outcrops or subsurface information are available to indicate the nature of the bedrock, this is shown on plate 1 , and only the more continuously covered areas are mapped as surficial talus and slope wash. Hence, the mapping is generalized and fails to indicate the true extent of the debris cover. Even where the bedrock geology is shown on the map, many of the lines have to be dashed to indicate a degree of uncertainty that is always present where geologic relations are partly obscured by the products of surficial disintegration.

Landslide deposits.-The landslide deposits, which are also extensive in the Rico district, differ from the talus and slope wash chiefly in that larger individual blocks of rock are involved. Such blocks have broken loose and moved en masse down the slope on gliding planes nearly parallel to the surface. However, the evidence in most areas indicates that many slide slices are involved in a given slide area. Cross (in Cross and Spencer, 1900, chap. 5) has devoted a chapter to a discussion of landslides in the district. The area underlying $\mathrm{CHC}$ Hill, embracing about 1 square mile, has been of particular economic interest because most of the mine openings in this hill have had to traverse the slide rock before the ore-bearing bedrock is reached. The landslide material here is several hundred feet thick (Ransome, 1901, p. 306). At its north end, the slide has pushed the Dolores River westward against the base of Sandstone Mountain, and the river has not yet cut its channel back down to the grade that existed prior to the slide (Cross and Spencer, 1900, p. 139, 162). For mapping, the landslides are hard to distinguish from extensive areas of slope wash into which, indeed, they grade, and the line between the two types is in places rather arbitrary. The landslides are equally troublesome in that they conceal the geologic features in large areas of bedrock.

Calcareous tufa.-The slopes of landslide and wash debris on the west side of the Dolores River south of Iron Draw are capped by patches of calcareous tufa. One small remnant is in the valley of Sulfur Creek at the west edge of the area shown on plate 1 . The southernmost patches mapped by Cross and Spencer $(1900$, pl. 22) cap torrential fan debris at the mouth of Burnett Creek, on the west side of the Dolores south of the area covered on plate 1. Doubtless the tufa was deposited by the waters from a series of carbonate springs, but the source spots are not now identifiable. There has been some incision of Sulfur Creek below the depositional surface of an adjacent patch since the tufa was deposited, for in the immediate valley trench of the creek, the deposit has been eroded.

\section{IGNEOUS ROCKS}

The Rico district is on the east side of a monzonite stock which is intruded near the center of the Rico dome. Closely related to the rock type found in this plutonic mass is a hornblende latite porphyry that crops out in a complex pattern of sills and dikes through and surrounding the mining district (pl. 1). In one of the thick sills, the rock has locally differentiated to a more quartzose phase. A third rock type, subordinate in bulk, is alaskite porphyry which occurs in a few dikes in the area north of the central uplifted block. A fourth type, lamprophyre, is represented in a single dike. Table 3 gives the results of rapid rock analyses made on three of the types in the laboratories of the U.S. Geological Survey.

\section{MONZONITE}

\section{DISTRIBUTION AND DIMENSIONS}

The outcrop of the intrusive monzonite stock west of the river at Rico is about 2 miles long in an eastwest direction and 1 mile wide (Cross and Ransome, 1905). At its north side a prong crops out nearly down to the level of the river, but, farther south, the apparent edge of the stock is higher on the slope, though the exact edge is everywhere concealed by surface wash. Plate 1 shows only the east side of the stock. 
TABLE 3.-Chemical compositions, in percent, of igneous rocks from the Rico district, Colorado

[Analyses by standardized rapid methods]

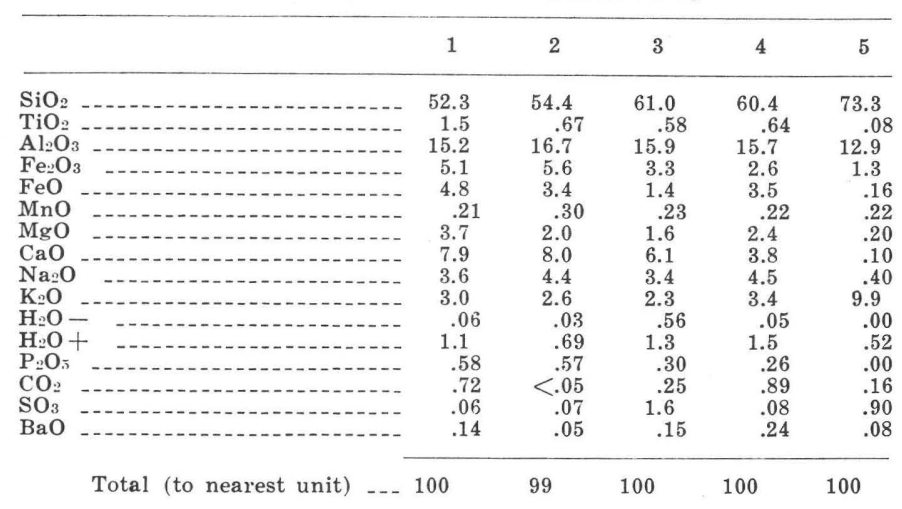

1. Monzonite from Rico stock, hornblende phase; from dump of caved tunnel, about $100 \mathrm{ft}$ inside stock, altitude $9,360 \mathrm{ft}$, left slope of Iron Draw $700 \mathrm{ft}$ from creek.

2. Monzonite from Rico stock, augite-biotite phase; from dry draw about 500 feet inside stock, altitude 9,540 $\mathrm{ft}$, at west edge of mapped area (pl. 1) $900 \mathrm{ft}$ north of switchback in Engel's mine road.

3. Latite porphyry from thick sill deep in Blaine tunnel, 2,460 ft east and $1,846 \mathrm{ft}$ south of portal

Latite porphyry from sill at top of middle Hermosa, in landslide block on old road at top of bench about $1,200 \mathrm{ft}$ south of CVG mine.

. Alaskite porphyry from dike about $30 \mathrm{ft}$ thick, northeast wall of Blackhawk fault, in crosscut from St. Louis adit to Rico Argentine mine about a quarter of a mile southeast from St. Louis adit (pl. 2).

\section{PETROGRAPHY}

The rock is generally medium grained, light gray, and mottled by the black mafic minerals where fresh, but commonly pinkish on weathered faces. Sparse xenoliths of a fine-grained dark rock are of local occurrence. In a few places, orthoclase crystals are as much as 1 inch across, enclosing the plagioclase and mafic minerals poikilitically.

Zoned andesine forms 50-60 percent of the rock; orthoclase or microperthite generally form 25-30 percent, and the mafic constituents form 15-20 percent; and their relative proportions vary from place to place. Commonly, hornblende, augite, and biotite, or their alteration products, are all present. In some blocks of the monzonite, however, hornblende is the only mafic mineral, whereas in other blocks augite and biotite are present, virtually to the exclusion of hornblende. Quartz is widely distributed but is everywhere a very minor constituent. Magnetite, sphene, and apatite are common accessory minerals; zircon is rare.

The orthoclase crystallized interstitially to, and encloses, the andesine crystals, which are generally corroded. Augite occurs in prismatic crystals, though generally with irregular ends. Hornblende, which is a light blue green parallel to the slow ray in thin section, is anhedral, except for common prismatic elongation. It may be molded against, or contain inclusions of, the andesine crystals. Where hornblende and augite are both present, they may be intermottled, or the hornblende may lie, with ragged contact, irregularly along the peripheries or adjacent to cracks in the augite cores. Biotite may replace crystals of the hornblende or augite along cleavage cracks, leading ultimately to pseudomorphs in which only small remnants of the original mineral remain in parallel optical orientation.

Quartz is in small anhedral and interstitial grains. Commonly, separated grains are in parallel optical orientation, and in places a graphic intergrowth with orthoclase is present on a microscopic scale. Sphene occurs in anhedral or euhedral grains that are commonly $1 \mathrm{~mm}$, and exceptionally, $2 \mathrm{~mm}$ across. It tends to segregate with the augite and hornblende and may be molded interstitially against earlier augite or andesine crystals, but it is euhedral against orthoclase and quartz. Magnetite is generally anhedral, but the grains may show crystal faces on one or more sides. Apatite is generally in well-formed prisms as much as $1 \mathrm{~mm}$ long.

A phase of the monzonite occurs in dikes, 1-10 feet thick, inside the Black Wonder workings; one dike turns into a sill on the upper level. There is also a poor exposure, apparently a dike, on the old road 220 feet south of the Black Wonder portal. All known occurrences are within 200 feet of the stock, east prong. The rock is pink and predominantly microperthite, though the original composition has been generally masked by alterations that have destroyed the mafic minerals and most of the plagioclase. Perhaps least altered is that exposed on the road, which contains about 80 percent microperthite, 10 percent albite, and a little brown hornblende, sphene, and magnetite among the otherwise predominantly deuteric constituents that compose the remaining 10 percent. Carlsbad twins are here common in the microperthite but are sparse or missing in the dike rocks cut in the Black Wonder workings.

Analyses of two phases of the freshest monzonite from the stock, given in table 3 , show that the rock is close in composition to mangerite (Nockolds, 1954 , p. 1018), which includes monzonite that approaches a diorite. The mineralogic composition also accords with this designation. The chemical composition is close to that of a monzonite in the La Plata Valley above Basin Creek in the La Plata Mountains, Colo. (Cross and Spencer, 1900, p. 82).

\section{ALTERATION OF MONZONITE}

The feldspars of the monzonite show varying degrees of sericitization, commonly within a single thin section, but in undeformed rock the average is fairly fresh. Epidote is a less abundant alteration product of both feldspars. In addition to a presum- 
ably magmatic transformation from augite to hornblende, augite has locally altered to a fibrous uralitic hornblende, and both augite and hornblende are commonly altered to chlorite and subordinate epidote. A little calcite has formed as an alteration product of the several calcium-bearing minerals.

Along shear zones in the monzonite, these alterations are intensified, commonly to the extent that the primary minerals have been completely destroyed.

The monzonite locally contains thin crack fillings of later minerals, some of which may be considered as late deuteric products of the magmatic cooling, others as alteration products; the distinction is not very clear cut. These minerals include pink orthoclase, epidote (including a pink manganiferous phase), hornblende, biotite, sphene, chlorite, and quartz. Commonly, several of these minerals may occur together, or epidote may occur alone.

\section{HORNBLENDE LATITE PORPHYRY}

DISTRIBUTION, SHAPES, AND DIMENSIONS OF ROCK BODIES

The most widely distributed igneous rock of the district is the hornblende latite porphyry that forms sills and dikes through the outcrop area and in the mines. Maximum extent is over an area about 7 miles in diameter, centered roughly on the Rico stock (Cross and Ransome, 1905; Cross and Hole, $1910)$. Only part of this total area is shown on plate 1. Mapping of latite porphyry bodies on plate 1 is somewhat generalized, for they are discontinuous, they change unexpectedly from concordance to discordance with the sedimentary strata, and they are commonly in thin bodies of insignificant extent as cut on the outcrop. In areas of poor exposure, porphyry float may be the only indication of occurrence, but the location and attitude of the source body cannot be projected on the map. Study of the mines shows that porphyry bodies commonly cannot be projected from one level to another, or from the surface to the underground, though perhaps conditions are somewhat more complex in the broken blocks of ground in which the mines are located.

Within the Rico district, the sills range in thickness from a few feet to about 525 feet. The thickest is intruded 240-278 feet above the base of the Hermosa Formation in Newman Hill. ${ }^{2}$ It is poorly exposed, but its full thickness was intersected between depths of 180 and 705 feet in Pelleyre diamond-drill hole 2, drilled from the Lexington tunnel. Hole 1

\footnotetext{
2 These figures are based on the four diamond-drill holes put down by the Pelleyre Mining \& Milling Co. in Newman Hill, assuming that the conglomerate mentioned (p. 15) as Larsen Quartzite equivalent is correctiy correlated. The interval is 278 and 275 feet, respectively, in holes
}

from the tunnel showed a 50-foot parting(?) of "sandy limestone" beginning 73 feet below the top of this sill. A higher sill, 50 feet thick, is separated from the main sill by 30 feet of strata in hole 2, and it was also intersected in hole 1. Possibly, these sills may have coalesced elsewhere in Newman Hill. The easternmost exposures of the main sill are at the bend in the access road 900 feet southwest of the Log Cabin (Blackhawk) tunnel, and the sill rock shows in the dumps of prospect shafts $300-400$ feet west of this tunnel. The sill cut in the footwall of the Blackhawk fault near the end of the Blaine tunnel (pl. $3 C$ ) probably represents the attenuated extension of this sill underground. What may be the same sill is present on the nose of Nigger Baby Hill south of the Last Chance fault, but poor exposures and intervening faults preclude any definite correlation. In the absence of stratigraphic controls, correlation with sills on the west side of the Dolores River may be equivocal. However, the Newman Hill sill appears to have split in this area into several subsheets, the thickest of which includes the portal of the Argonaut tunnel on Sulfur Creek (pl. 1).

A persistent sill near the top of the middle Hermosa extends from Sandstone Mountain to the north slope of Silver Creek. On the nose of Sandstone Mountain, the sill is 75 feet thick and splits the uppermost limestone ( $\mathrm{L}$ bed) of the middle Hermosa at 7 feet below its top. The sill can be traced northeast to where it disappears beneath the alluvium of the Dolores River at Burns. Over much of this stretch it is at, or just above, the top of the middle Hermosa (pl. 1). Owing to concealment by landslide debris, there are no in-place exposures in CHC Hill, but rubble from the sill is present in a landslide block 1,200 feet south of the CVG mine, along the old road that traverses the east side of the river. The next exposure of the sill is on the nose of Nigger Baby Hill where it is brought up on the south side of the Nellie Bly fault. Here, it is at the top of the middle Hermosa. Although exposures to the east are poor and complicated by faulting, the sill crops out adjacent to the draw northwest of the Iron mine. It has risen in the stratigraphic section here to about 75 feet above the middle Hermosa. The last-known occurrences are in the underground workings of the Rico Argentine mine-at the north end of the 300 level and in the St. Louis crosscut on the 500 level. At the latter locality the sill appears to be about 115 feet thick and its base is 140 feet above the middle Hermosa. Except for a segment between the west and middle prongs of the Blackhawk fault at Burns, the known occurrences of the sill are all in the footwall of the fault. The sill is 
not present in the hanging wall above the Argentine and Log Cabin tunnels of the Rico Argentine mine southeast of Silver Creek, only a short distance from the thick occurrences in the opposite side of the creek. There is no convincing evidence that the Blackhawk fault has been the limiting factor in the distribution, though the possibility is at least suggested.

Another thick sill, intruded about 800 feet above the base of the Cutler Formation, forms the top 150 feet of Dolores Mountain. The top of the sill has been eroded here, but exposure in the downfaulted wedge to the northeast indicates a thickness of about 250 feet. What may be the same sill appears in fault blocks to the east and northeast as far as the ridge on the northeast side of the Blackhawk fault where the sill is about 330 feet thick. If most of the faulting is later than intrusion of the sill, as some of it certainly is, the correlation through the different fault blocks seems reasonable; a rough calculation indicates that the horizon of the intrusive body northeast of the Blackhawk fault is at least within 40 feet of that on Dolores Mountain.

Many other sills of lesser size are present in the district. Most are less than 50 feet thick. The one that crops out on the north side of Silver Creek northeast of Rico is in the lower part of the Hermosa Formation, below the thick Newman Hill sill, as is also a thin lenticular one at a slightly higher level. A sill that is probably the lower of these was intersected in Pelleyre holes 5 and 3 near the New Year portal in Newman Hill, but it was not found in the holes put down from the Lexington tunnel. The sill is 22 feet thick, and is 117 feet and 106 feet above the presumed base of the Hermosa in holes 5 and 3 , respectively, in comparison with 94 feet above the base of the Hermosa at the Ahkeah tunnel.

Dikes of the hornblende latite porphyry are much less common than the sills in the Rico district. Several are present on the west side of the Dolores River near the north limit of the mapped area (pl. 1), and scattered dikes show elsewhere, including several in the mines. Few are more than 30 feet wide. The widest dike found, 60 feet, is near an altitude of 11,600 on top of the ridge between the two prongs of Allyn Gulch, northeast of Dolores Mountain, but this dike has short linear extent. A dike 50 feet wide, on which there has been significant fault displacement, strikes northwest between the Shamrock and Potter tunnels on the west side of the Dolores at Rico, but only a short segment is exposed between the river and the surficial debris higher on the slope.

A dike that would otherwise be of no special significance but which is related to several ore de- posits in the Rico Argentine mine is herein named the Rico Argentine dike. It is cut by mine workings on the 300, 200, Blaine, and Argentine levels of the mine (pl. 3) but has not been recognized on the surface. This dike is generally $15-20$ feet thick, strikes N. $30^{\circ}-35^{\circ}$ E., and stands nearly vertical, though study of its position on the different levels indicates that it dips steeply to the southeast. Its minimum exposed length as projected between the 300 and 200 levels is about 530 feet, but the northeast end has nowhere been cut by underground workings. The southwest end terminates abruptly against the Honduras fault on the Argentine level and terminates at least near this fault on the Blaine level, but it apparently crosses the Honduras fault zone on the 200 level and presumably terminates against the Blackhawk fault, though the definitive ground has not been cut by the mine workings. At the crossing of the Honduras fault, the dike appears to be later than the major displacement on the fault. However, the dike was broken here and was elsewhere broken and offset by movement along small breaks that may be related to late movement on the Honduras and Blackhawk systems. It was presumably this late movement that fractured the country rock along the edges of the more rigid porphyry dike, making the fractured ground favorable for ore deposition.

There is much porphyry in the vicinity of the Blackhawk fault in the mines south of Silver Creek (pl. 3). Much of this occurs as irregular sills, but some of the bodies crosscut the strata along the fault. These dikelike bodies are irregular and discontinuous, possibly in part because of late faulting.

The absence of textural variations that would indicate chilling at contacts with the country rock suggests that the ground was well heated by the time the dikes and sills were injected. The extreme fluidity of the magma indicated by the thinness of the rock bodies is further evidence of this possibility.

\section{PETROGRAPHY}

The fresh hornblende latite porphyry is a speckled rock with conspicuous white phenocrysts of plagioclase and less abundant slender laths of hornblende in a gray groundmass. The texture commonly differs in detail from one rock body to another. Maximum phenocryst length is generally about one-quarter of an inch, rarely to one-half of an inch. In some sills the groundmass has a faint lavender tinge, and in a few it is pinkish brown. Orthoclase occurs only rarely as phenocrysts, but is a common microscopic constituent of the groundmass that also contains minor quartz. 
The plagioclase phenocrysts are moderately zoned and are andesine in most occurrences. Exceptions are in the thick sill on top of Dolores Mountain, where the plagioclase is on the andesine-labradorite border; in a short dike on the slope 1,000 feet east of the Log Cabin tunnel, where it is labradorite of about $\mathrm{An}_{55}$ composition; and in a sill within the vein zone in the Revenue tunnel, where it is labradorite of about $\mathrm{An}_{63}$.

The only observed occurrence of orthoclase as phenocrysts is in a highly altered sill forming the roof of the 305 winze on the 300 level of the Rico Argentine mine. The phenocrysts are well-formed crystals which are as long as an eighth of an inch; some show Carlsbad twinning. Associated plagioclase crystals here have been completely destroyed by alteration.

The hornblende of the porphyry shows much more color in thin section than that of the monzonite. The color parallel to the direction of greatest absorption is a dark blue green in most rock bodies, though of only medium intensity in a few. In some crystals interspersed with the normal dark ones of the sill at the top of the middle Hermosa in Sandstone Mountain (unit 57 of the section), a sharp difference may exist between dark-colored cores and mediumcolored peripheries, though the color intensities are not always symmetrically distributed. Pale hornblendes comparable to those in the monzonite were found only in a thick sill, probably the Newman Hill sill, deep within the Blaine level of the Rico Argentine mine. Small inclusions of hornblende have commonly been entrapped inside the plagioclase phenocrysts.

Quartz grains occur only sparingly as a primary constituent in the porphyry, except in the thick sill on top of Dolores Mountain where apparently some differentiation to a more quartzose phase has taken place. Some groupings of quartz grains in the normal porphyry are suspected of being a secondary hydrothermal or alteration product.

Magnetite, apatite, and sphene are common accessories; allanite is only moderately common ( $0-2$ grains per thin section); and zircon is rare. These minerals tend to be concentrated in the hornblende phenocrysts, or in the chlorite or calcite that has altered from the hornblende, but they are also present in the groundmass. Magnetite grains may be euhedral or anhedral, and are commonly as large as $0.5 \mathrm{~mm}$, exceptionally $0.8 \mathrm{~mm}$, in diameter; there may be two groups of grain sizes in some sills, the smaller size corresponding with the groundmass generation. Apatite is mostly in euhedral prisms as long as $0.5 \mathrm{~mm}$ or, exceptionally, $1 \mathrm{~mm}$. Average- sized crystals may be present inside plagioclase phenocrysts or in hornblende or sphene. In some sills the apatite grains are somewhat rounded, as though corroded. Sphene crystals vary greatly in size in different rock bodies. The largest observed are $2.25 \mathrm{~mm}$ long, though $0.5-1.0 \mathrm{~mm}$ is a common maximum length. A few are euhedral, but most are partially or completely anhedral. In one sill on the south side of Dolores Mountain, sphene is greatly concentrated in calcite that has altered pseudomorphously from hornblende. Allanite is in rounded partly twinned grains, and zircon occurs sparingly in minute grains, rarely as long as $0.15 \mathrm{~mm}$.

The groundmass contains laths of orthoclase showing good to poor elongation. In some thin sections, a few slightly coarser laths are twinned plagioclase, and in others, the plagioclase may form a considerable percentage of the groundmass. Very fine magnetite and apatite are common. Fine granular quartz is, in general, a minor constituent of the groundmass, but in a few sills and dikes it becomes a significant component, in part as a micrographic intergrowth with the granular orthoclase. In such intergrowths that border or surround clear quartz phenocrysts, the quartz is in optical parallelism with that of the phenocryst. The groundmass is commonly clouded from incipient alteration. A trachytic texture is present in a few sills, particularly in one that is well up in the Cutler Formation northeast of CHC Hill.

Analyses of two of the freshest sills, given in table 3 , indicate a somewhat higher percentage of silica than in the monzonite of the central stock. This higher percentage of silica is reflected in a slightly larger amount of quartz in the rock, though hardly enough to rate recognition in the naming of the rock. The analyses are very close to that of a "diorite-porphyry" in the La Plata Mountains, Colo. (Cross and Spencer, 1900, p. 86). As in the monzonite of the stock, the analyses indicate an approach to the composition of diorite, but even more to that of the average quartz diorite (Daly, 1933, p. 15, 16) or dacite (Nockolds, 1954, p. 1015). The designation as latite is in recognition of the amount of orthoclase in the rock, though the closest resemblance is to the doreite variety of latite (Nockolds, 1954, p. 1018).

\section{QUARTZOSE PHASE CAPPING DOLORES MOUNTAIN}

The porphyry at the top of Dolores Mountain is about 150 feet above the base of a sill which is estimated to have been 250 feet thick before erosion of its upper part. This porphyry differs from that elsewhere in that it contains very little of the 
groundmass material. Much of the excess of crystalline material is an interstitial quartz which is in optically continuous units over appreciable grain sizes, but in detail is intergrown with subordinate orthoclase in a near-graphic granite pattern. The crystal centers of the zoned plagioclase phenocrysts have a composition on the andesine-labradorite boundary. This rock is thus a quartz monzonite in composition but is probably a very local differentiation product near the center of the sill. It does not differ in general appearance from the other porphyries, except in its more holocrystalline tendency. As this difference is unmappable in the field, the rock has not been differentiated on plate 1 , if, indeed, it is anything more than a very local phase with gradational boundaries.

\section{XENOLITHS}

Xenoliths are rare in the porphyry. A small block of quartzite, possibly from the Uncompahgre Quartzite, was found in a thin sill just above the base of the Rico Formation on the ridge southeast of the Log Cabin (Blackhawk) tunnel, about threequarters of a mile east of the quartzite outcrop. Small fragments of quartzite are occasionally found in sills within the mines. A large float boulder of the porphyry in the bed of Deadwood Gulch at the top of the middle Hermosa ledge contained a granite block, 8 by 4 inches in section, of a type that is unrepresented elsewhere in the district. This granite contained quartz, hornblende, and pink orthoclase, the latter in crystals as much as threequarters of an inch long, and showed a crude gneissic layering of the quartz and hornblende in the feldspar. Rounded to angular hornblendic xenoliths as much as several inches across and containing only minor or no feldspar are of sporadic occurrence in the porphyry. An angular one, 6 inches long, was found in a float block on the Rico Formation outcrop in the bed of Deadwood Gulch, nearly 2 miles southeast of Rico. These xenoliths resemble the metadiorite outcropping in the Precambrian block north of town.

\section{ALTERATION OF HORNBLENDE LATITE PORPHYRY}

In hand specimens of moderately altered rock the plagioclase is whiter than in fresh rock or may be green from epidote, and the hornblende has changed to gray-green chlorite with loss of definition in crystal edges. In many of the altered rocks the hornblende has been leached out, and the cavity may contain a rust coating or minute clear crystals of apatite. Porphyry that has been subjected to hydrothermal alteration in the mines has become a gray, greenish-gray, or whitish talcy-lustered rock with only obscure or no evidence of phenocrysts of any kind, and it is hard to distinguish from similarly altered sedimentary rocks.

Microscopic examination shows that the feldspars are somewhat, though unevenly, sericitized, even in fresh rock. More intense alteration converts the plagioclase phenocrysts completely to sericite pseudomorphs, but the relict textures generally reveal the igneous antecedence that is obscured in hand specimen. Although a paragonitic sericite might be expected from plagioclase phenocrysts, the X-ray powder pattern of a sericitized phenocryst taken from a porphyry mass deep within the Blaine tunnel indicates a modified muscovite. Fine granular epidote and calcite, massed at the phenocryst spots, are also very common alteration products of the plagioclase; quartz is less common. Chlorite replaces plagioclase to some extent inside the boundaries of the plagioclase crystals but is hardly a direct alteration in view of the differences in chemical constituents. Kaolinite occurs as an alteration product of the feldspars in some samples collected from the mines, but only rarely is it conspicuous.

Orthoclase phenocrysts in their only observed occurrence in the porphyry, on the 300 level of the Rico Argentine mine, are evidently more stable than associated plagioclase phenocrysts that have been completely altered here. The orthoclase shows some clouding, which is probably kaolinite.

The hornblende has been altered extensively to chlorite, which begins along cracks or around edges but eventually engulfs the whole crystal. In many rocks that otherwise look comparatively fresh, the chlorite faithfully preserves the crystal form of the hornblende, but more extensive alteration leads to ragged boundaries, and eventually all evidence of pseudomorphism is lost. Carbonate is another common alteration product of hornblende. It can occur alone in a pseudomorph, but more commonly is mixed with chlorite in this role. Some pseudomorphs of hornblende in moderately altered rock have a fine peppering of black opaque material, presumably magnetite, on the original boundaries of the crystals. Epidote is also a common, and generally intermixed, alteration product of hornblende, but as in plagioclase, it does not commonly make good pseudomorphs. Quartz accompanies the other alteration products in many places. Sericite may also be present, and in a few altered rocks a phlogopitic sericite is the major secondary product that has replaced the primary hornblende. Rarely, actinolite accompanies the commoner alteration products. In the sill on top of Dolores Mountain, a little brown biotite inter- 
mixed with chlorite and carbonate has evidently altered from hornblende.

Sphene has altered to leucoxene, a material of uncertain composition but largely some form of titanium dioxide (Tyler and Marsden, 1938). Possibly some leucoxene in chlorite may have been derived from titanium in the original hornblende rather than from included sphene. In contrast, apatite, allanite, and zircon have been stable under the conditions of hydrothermal alteration, though the apatite shows slightly ragged boundaries in some instances.

The minerals that form as alteration products of the plagioclase, hornblende, and sphene phenocrysts are also common in the groundmass where they may have altered from groundmass minerals. Thus, much of the scattered fine-grained quartz in the groundmass may be an alteration product. Most of these secondary minerals also appear in microscopic replacement veinlets that anastomose through the rock. In general, the groundmass tends to be less altered than the phenocrysts, probably because its major constituent, orthoclase, is more stable than the phenocryst minerals.

In the more intensely altered porphyry in which the secondary minerals are in anhedral crystals or crystalline aggregates showing no evidence of pseudomorphism after primary minerals, details of composition and texture of the original rock can only be surmised from a study of thin sections. Thus, presumably many of the large chlorite clumps represent spots originally occupied by hornblende crystals, but these spots cannot be specifically so identified in thin section. In the porphyry that has undergone hydrothermal alteration in mineralized ground, magnetite has disappeared, but pyrite is abundant in small to minute crystals (cube, or cube modified by pyritohedron) or anhedral blebs. Possibly, the iron was converted from oxide to sulfide in this alteration; but iron could have been obtained from other primary minerals, and pyrite was such a pervasive accompaniment of the hydrothermal mineralization that it is generally present regardless of earlier iron-bearing minerals.

The sericite in three samples of intensely altered porphyry has been identified from X-ray powder patterns as muscovite by Mary Mrose, of the U.S. Geological Survey. Two of the samples were taken from the hanging wall within 30 feet of the Blackhawk fault on the Argentine level of the Rico Argentine mine, and the third was from 125 feet in the hanging wall of the fault on the Blaine level.

Clear orthoclase occurs as an uncommon alteration product in a few hydrothermally altered por- phyry masses where it either permeates the groundmass in fine grains and in replacement veinlets, or, in association chiefly with sericite but also with calcite or epidote, replaces phenocrysts that are no longer identifiable. In the latter instance, the orthoclase granules within the crude pseudomorphs are in optical parallelism. The associated epidote is a pink variety (withamite) from introduced manganese. This alteration is doubtless due to permeation by potassium- and manganese-bearing solutions contemporaneous with the igneous metamorphism of the sedimentary rocks, which show similar introduction of orthoclase and manganiferous minerals. More intense alteration of this type has produced garnet, phlogopite, and clinozoisite in the thick porphyry dike that is close to the monzonite intrusive body north of the Shamrock mine.

In a 10-foot porphyry dike just south of, and nearly parallel to, the fault vein at the Aztec mine, the plagioclase phenocrysts have been metasomatically replaced by albite $\left(\mathrm{An}_{5}\right)$. The phenocrysts appear to be fresh in hand specimen, but a thin section shows that they are moderately sericitized and contain a little chlorite. They are bounded by good crystal faces, are well twinned, and unzoned. The associated hornblende has been completely altered to ragged clumps of chlorite, carbonate, and a little quartz, but there is no epidote in the rock. This porphyry is a typical example of the keratophyres, formed by albitization of the plagioclase in a more basic dike rock (Gilluly, 1935). Some of the albite twinning shows the "chessboard" pattern that is commonly interpreted as resulting from replacement (Gilluly, 1933, p. 73).

\section{ALASKITE PORPHYRY DISTRIBUTION AND DIMENSIONS}

The alaskite porphyry crops out at very few places. At the Aztec mine, a dike about 15 feet wide is poorly exposed between the portals of the lower and upper tunnels a few feet north of the quartz vein on which this mine is developed. Although not exposed at the portal of the lower tunnel, the dike projects to within less than 10 feet of this portal, but it diverges from the vein at a low angle into the hanging (north) wall as the vein, presumably on the Nellie Bly fault, is followed northwestward. The dike walls are irregular in detail, but probably the average dip is steeply north-northeast, parallel to the quartz vein. In the first 100 feet northwest from the lower portal, an irregular dikelike mass of the normal latite porphyry, with associated sedimentary rock material, intervenes between the alaskite porphyry dike and the quartz vein. The 
mapping shown on plate 1 is partly generalized and projected from the underground mapping of the lower mine level which crosscuts into the hanging wall.

A separate body of the alaskite porphyry is exposed in the roadcut on the upper side of the access road, 120 feet northeast from the lower portal. The rock is concordant for an exposed thickness of 6 feet beneath sandstone and shale, but whether it is an irregular sill or the top of an igneous knob cannot be determined from the limited exposure. The outcrop length is only 30 feet, and in view of the uncertainty as to shape and size of the mass, it cannot be extrapolated beyond a thin short line on plate 1.

Irregular small crosscutting knobs and dikelike masses of the alaskite porphyry are also cut underground on the upper level of the Aztec mine. These exposures are near the vein, in both its hanging wall and footwall, beginning 350 feet from the portal and extending discontinuously to the end of the tunnel, 525 feet from the portal. The last fault movement on the vein here was later than the alaskite, but it appears obvious that fracturing along the fault zone produced the initial channels along which both the alaskite porphyry and latite porphyry were introduced. An irregular small sill-like, but partly crosscutting, body of the alaskite porphyry was also cut in the Edwards tunnel whose portal is 260 feet east of, and 68 feet below, the lower portal of the Aztec. No great amount of crosscutting would be necessary for this latter body to connect above with the small surface outcrop on the access road to the Aztec mine.

Possibly these small bodies exposed underground and in the roadcut may be remote appendages of the 15-foot dike at the Aztec mine, but, if so, the connections are tenuous and obscure. All known occurrences of the alaskite porphyry in this general area are within 200 feet of the Aztec vein, and mostly within its hanging wall.

A small dike lens of the alaskite porphyry crops out in the cliff of the Rico Formation about 1,000 feet north of Strawberry Spring. This lens strikes about N. $30 \mathrm{E}$. and shows a maximum thickness of 6 feet, but dies out upward.

A dike of the alaskite porphyry, 7-10 feet thick and 1,000 feet long, occupies a major fault break on the south slope of Silver Creek, about a quarter of a mile east of the Argentine shaft. This dike was emplaced later than the faulting.

An alaskite porphyry dike with steep, but irregular, walls and averaging perhaps 25 feet thick was intersected by the St. Louis tunnel at a point 195 feet within the footwall of the Blackhawk fault (pl. $2 C$ ). The trend is roughly parallel to the fault. Another dike of the same rock, or possibly the same dike, perhaps 30 feet thick, appears a quarter of a mile to the southeast on the hanging wall of the Blackhawk fault where it is intersected by the long crosscut from the St. Louis tunnel to the Rico Argentine mine. As the intersection is at a very acute angle, the thickness of this dike can be only approximated. The dike is possibly continuous with the one a quarter of a mile east of the Argentine shaft, for the latter is on a fault that evidently joins the Blackhawk fault in unexposed ground between the two localities.

Other bodies of the alaskite porphyry in close proximity to the Blackhawk fault were cut in the Pigeon mine tunnel. These are small irregularly crosscutting dikes at two places about 500 feet apart, and each not more than 50 feet within the hanging wall of the fault (pl. $2 C$ ).

What is probably a highly altered phase of the alaskite porphyry is poorly exposed in an outcrop only a few feet long in the willows at the alluvium border on the west side of Dolores River nearly opposite the mouth of Silver Creek. Because of poor exposures in this area, the attitude of the rock body is not known.

\section{PETROGR.APHY}

Rounded phenocrysts of quartz are conspicuous in the whitish, pale-gray, or pale-drab groundmass, though they never form more than 3 or 4 percent of the rock. Orthoclase phenocrysts are preserved only in the two dikes in the St. Louis tunnel where they form 6-10 percent of the rock. In other occurrences, the feldspar phenocrysts have either been converted to secondary minerals or leached out.

In thin section, the quartz phenocrysts are commonly corroded and contain embayments of the groundmass, but they also tend to show rhombic cross sections, or basal sections that are hexagonal. Orthoclase phenocrysts are subhedral and rather stumpy, as they lack any pronounced elongation in thin section. In one of the St. Louis dikes, the orthoclase phenocrysts tend to aggregate into clumps, each of three or four crystals. There are no mafic minerals.

The groundmass varies in the relative proportions of quartz and feldspar. In the freshest rock, quartz forms 20-40 percent, and orthoclase, the remainder. The texture is equigranular, though the orthoclase units show fair elongation in one of the St. Louis dikes. A crude micrographic texture is locally present in the groundmass adjacent to quartz 
phenocrysts wherein the quartz of the intergrowth is optically parallel to that of the phenocrysts. Fine prisms of zircon are rare, and an alteration product suggests the former presence of a little sphene locally.

Analysis of the freshest sample available from one of the dikes in the St. Louis tunnel (see table 3 ) indicates an exceptional rock containing 9.9 percent $\mathrm{K}_{2} \mathrm{O}$ and only 0.40 percent $\mathrm{Na}_{2} \mathrm{O}$. On the basis of the amount of $\mathrm{SO}_{3}$ in the analysis, about a third of the $\mathrm{Fe}_{2} \mathrm{O}_{3}$ reported in the analysis is in pyrite, leaving 0.9 percent in other constituents of the rock. Except for the imbalance in the alkalis, the analysis resembles those of certain rocks from Ascutney Mountain, Vt., which Johannsen (1932, p. 69, 71) classes as "kalialaskite porphyry," and similarly resembles those of the plutonic and extrusive equivalents of these rocks (Johannsen, 1932, p. 49, 63). The rock is an extremely potassic tordrillite as defined by Spurr (1900, p. 229-232). The type tordrillite is a dike rock, but the name has been extended by Spurr and others to include extrusive rocks of the same composition and texture. The great imbalance between the alkalis in the porphyry dike from the St. Louis tunnel (table 3) may well be due to late deuteric substitution of potassium for sodium, similar to the mutual substitutions that characterize the keratophyres (Battey, 1955; see also, Terzaghi, 1948).

\section{XENOLITHS}

The 15-foot dike at the Aztec mine contains sporadic quartzite inclusions of an unidentified source. Rounded inclusions 1 inch in diameter and angular ones as much as 3 inches in diameter have been noted.

The small dike in the Rico Formation north of Strawberry Spring contained an ellipsoid pebble of quartzite half an inch long and slightly less than this in the transverse diameter. This pebble readily broke free from the igneous matrix, revealing a well-polished surface of the type characteristic of advanced stream rounding. The possibility that the magma picked up this pebble from one of the conglomerates traversed is too great to justify further speculation that this particular pebble was brought up from the Precambrian and somehow rounded in the process.

\section{ALTERATION OF ALASKITE PORPHYRY}

In all known occurrences other than the St. Louis dikes, the feldspar has been completely altered. The phenocrysts are in part leached, but, more generally, have been replaced by sericite and carbonate, locally accompanied by quartz; whereas the groundmass feldspar has altered chiefly to sericite but also to small amounts of the other replacing minerals. Even in the St. Louis dikes, much sericite and carbonate have formed in the feldspar phenocrysts, tending to segregate with zonal boundaries or in ragged clumps, leaving the rest of the feldspar relatively unaltered. A little leucoxene in one of the St. Louis dikes was doubtless altered from sphene.

In addition to forming crudely pseudomorphic aggregates after feldspar, the secondary quartz, carbonate, and sericite may segregate in small pockets and replacement veinlets. The quartz in these secondary occurrences tends to prismatic habit in contrast to the bipyramidal grain habit that characterizes the primary phenocrysts. A little clear secondary orthoclase locally accompanies the quartz in the veinlets.

Fine pyrite in anhedral grains or cubic crystals is disseminated through most bodies of the alaskite porphyry. It occurs indifferently in the groundmass, in the replaced feldspar phenocrysts, or in the secondary mineral pockets and veinlets. Rather than representing an alteration product from some specific iron-bearing primary mineral for which there is no tangible evidence, this pyrite is probably a phase of the general pyritization that permeated the district as part of the mineralization cycle.

\section{HORNBLENDE LAMPROPHYRE}

A single lamprophyre dike, 2 feet thick and nearly vertical, cuts the limestone at the top of the middle Hermosa on a spur ridge above Newman Hill a mile southeast of Rico. The rock is aphanitic and very dark gray, but on close scrutiny it shows a. few phenocrysts of quartz and hornblende. One edge of the dike contains abundant amygdules composed chiefly of white ankeritic dolomite, partly leached out or oxidized. In some of the amygdules, part or all of the filling is a dense pale-bluish-gray mixture of the carbonate with sericite, the carbonate in this phase being microcrystalline in contrast with that in the sericite-free phase.

Thin sections show a highly altered rock in which scattered phenocrysts have been largely or entirely altered. Some pseudomorphs that are now finegrained carbonate and serpentine show typical augit, cross sections, and some of these have thin remnants of the augite in parallel orientation. The serpentine in these augite pseudomorphs contains a scattered opaque dust, presumably magnetite. Other pseudomorphs that are now fine-grained clear serpentine show the longitudinal section characteristic of olivine. Fine-grained magnetite and hema- 
tite are alteration products that have segregated especially along cross fractures or on the rims of the more thoroughly altered pseudomorphs, and pyrite occupies some of the rims. Although concentrically banded pseudomorphs are common, they are of the augite type, and at least some of them contain relict slivers of augite. If feldspar pseudomorphs are present, they have not been distinguished. The few hornblende phenocrysts are perfectly fresh and brown. Their refractive indices are $\alpha$ about $1.68, \gamma$ about 1.70 , and thus they resemble barkevikite, except that $2 \mathrm{~V}$ is too high (about $70^{\circ}$ ). The scattered quartz phenocrysts are large $(3 \mathrm{~mm}$ diameter) and of uncertain origin. They look like detrital grains of glassy quartz, but in thin section some are inside the carbonate patches, which suggests that they are amygdule fillings.

The groundmass is an intergrowth of small slender plagioclase laths, abundant slender brown hornblende laths of comparable size, grains of altered augite, fine subhedral magnetite, secondary carbonate, fine serpentine, and sericite. There is a little biotite and accessory apatite (prisms as much as $0.3 \mathrm{~mm}$ long). The hornblende, which is unaltered, commonly forms side rims to the augite pseudomorphs. The plagioclase is poorly twinned and corroded by alteration to the carbonate, hence, its composition has not been more closely determined, though a high-calcium plagioclase can be surmised from the chief alteration products. Clear remnants of the plagioclase contain abundant inclusions of fine and apparently colorless needles resembling tremolite.

This dike is generally similar to other basic dike rocks that have been mapped in the general vicinity of the Rico Mountains, though outside the area shown in plate 1 (Pratt and others, 1969). The mineralogic composition and particularly the abundance of brown hornblende suggest a classification as camptonite. The rock is too altered to warrant a chemical analysis.

\section{RELATIONS BETWEEN DIFFERENT IGNEOUS ROCK TYPES}

Because of poor exposures on the borders of the monzonite stock, no contact between the latite porphyry of the sills and dikes and the monzonite of the central stock is exposed in the area of plate 1 . Cross and Spencer $(1900$, p. 91), from mapping a somewhat wider area, reported that the stock cuts off porphyry sheets "in a few places," and from analogy with better exposed relations between comparable rocks in the La Plata Mountains and in the Telluride quadrangle, they surmise that the mon- zonite stock is later than intrusion of the porphyry. The absence of porphyry dikes observed inside the stock tends to corroborate, though it does not definitely prove, this surmise.

Although dikes of the latite porphyry and alaskite porphyry are in close proximity at the Aztec mine, at no place is there an exposed contact revealing their respective ages.

\section{AGE OF IGNEOUS INTRUSION}

In the Rico Mountains and in an area a few miles to the northeast, latite porphyry sills intrude strata as young as the Mancos Shale of Cretaceous age (Cross and Ransome, 1905; Cross and Hole, 1910; Bromfield, 1967). There are, however, no later strata that can be used in setting a younger limit for the age of intrusion. By analogy with other areas in the San Juan region in which later rocks are present, Cross and Ransome (1905) surmised that the latite porphyry was of Tertiary age and was probably emplaced during the latter part of the Tertiary. In the Ophir Loop area, 15 miles northeast of Rico, two stocks of diorite (chiefly) and monzonite intrude flows which are of Miocene or Pliocene age, namely the Potosi Volcanic Series as used by Vhay (1962), and at Grizzly Peak, only 10 miles northeast of Rico, a stock of quartz monzonite also intrudes the Potosi Volcanic Series as used by Cross and Purington (1899). On the other hand, in the Ouray district, a small stock, laccoliths, dikes, and sills of granodiorite porphyry, quartz monzonite porphyry, and quartz diorite porphyry are earlier than the Telluride erosion surface of early Tertiary age and are considered by Burbank (1940) to be probably of Late Cretaceous or early Eocene age. The principal ore deposits of the Ouray district are related to these early intrusive masses, though there are also upper Tertiary ore deposits in the Tertiary volcanic series. Burbank conjectured (his fig. 32) that the intrusive stock at Rico correlates with the Laramide intrusive bodies at Ouray.

Armstrong (1969) has published the ages of several laccolithic and related igneous bodies of the Colorado Plateau and vicinity as determined from potassium-argon ratios. Included in this study is a "dike" of hornblende-diorite porphyry cropping out four miles south of Rico. As mapped by Pratt, McKnight, and DeHon (1969), the igneous body here is a thick sill of the hornblende latite porphyry. However, where exposed in the roadcut at approximately the locality indicated by Armstrong's sample information, the top of the sill crosscuts the overlying strata for at least 20 feet, and the igneous body might well be identified here as a thick dike 
unless several adjacent outcrops are examined. The potassium-argon ratio obtained from the mafic constituents of this rock gives a spurious age, but that obtained from the whole rock, minus the heavy fraction, indicates an age of 61.3 million years (Armstrong, 1969). This age is consistent with ages similarly obtained by Armstrong from three other igneous bodies of the general region, and indicates a Laramide (Late Cretaceous or early Tertiary) age for the latite porphyry. The monzonite stock is believed to be nearly contemporaneous with the latite porphyry sills and dikes, but until its age is determined independently, the possibility remains that the age could be significantly younger. Contrary to the expected evolutionary trend toward more salic end products in consanguinous igneous masses, the stock is more mafic in composition than the earlier sills and dikes (table 3 ). This fact should, at least, offer some motive for further age investigation.

\section{IGNEOUS METAMORPHISM AREAL EXTENT}

Metamorphic changes produced by the monzonite intrusive body are most pronounced in the ground bordering its east end. The limestones, in particular, have been recrystallized to coarser grain and invaded by numerous silicates and iron oxides. Because of their position near the base of the section, the Leadville and Ouray Limestones have been especially vulnerable, and all known exposures have been metamorphosed to a considerable extent. On the present surface, pervasive metamorphism extends for about 0.4 mile east of the boundary of the intrusive rock to the lowest southwest slopes of Nigger Baby Hill, where Hermosa as well as Leadville limestones are affected. Beyond this, the effect is irregular and doubtless channelized. Specularite, garnet, epidote, and other metamorphic silicates are conspicuous in the Hermosa Formation, and the limestones are generally recrystallized to white finegrained marble as far east as the spur above the New Demon mine, which is 1.7 miles east of the exposed monzonite end. Where the limestone has been marbleized. accompanying shales are baked to a hard slaty character.

Distances from the monzonite border measured horizontally on the present surface are of less significance in relating the metamorphism to this igneous mass than distances considered in a vertical or diagonal dimension. The complicated faulting and upthrusting of basement blocks in a general zone running east from the end of the monzonite stock suggest very strongly that an extension of the stock lies at no great distance below the surface in this belt. Doubtless, heat and emanations for metamorphism of overlying rocks came from this buried prong.

Metamorphic silicates and specularite are also found locally in the workings of the mines along the Blackhawk fault in CHC Hill, and especially on Silver Creek, and also in upper Hermosa strata near the fault on the steep slopes to the southeast of Silver Creek, where the shaly beds are baked hard. In the metamorphism of these and similar areas, the numerous sills and dikes of latite porphyry have played the major role. Epidote, specularite, and diopside-hedenbergite, in particular, are likely to appear in the sedimentary rock adjacent to porphyry dikes and sills, regardless of distance from the monzonite stock. However, the metamorphism definitely attributable to the latite porphyry bodies is, in general, confined to the vicinity of such bodies and does not pervade large intervening blocks of ground, though in places the effects from the two sources of metamorphism may be mingled.

\section{MINERALOGY OF IGNEOUS METAMORPHISM}

Garnet, epidote, chlorite, and diopside-hedenbergite are the most abundant and widely distributed of the metamorphic silicates, occurring as replacement products in several types of host rock including limestone, shale, and arkose. The recrystallized marble derived from the Leadville Limestone contains numerous irregular segregations of these and other metamorphic silicates, commonly associated in group aggregates, and probably derived in part from original impurities in the limestone. The garnet may form a border to the epidote against the marble. Some of the epidote is colored pink from contained manganese.

Specularite and magnetite are also conspicuous in the metamorphic aureole, the magnetite chiefly in close proximity to the igneous stock where it may form rather massive bodies in which other metamorphic minerals are subordinate. Actinolite and tremolite occur in aggregates with other metamorphic minerals, but they also can occur disseminated in certain lower Hermosa limestones which otherwise show little alteration other than some recrystallization. Actinolite is found with garnet and epidote as far east as the upper Hermosa outcrops in the hanging wall of the Blackhawk fault, southeast of Silver Creek. Tremolite occurs with epidote and diopside-hedenbergite in the matrix of a lower Hermosa arkose in the hanging wall of the Blackhawk fault on the northwest crosscut from the St. Louis tunnel. In a few places, the amphibole in the meta- 
morphic zone is hornblende. Apatite and sphene are sparse constituents in the metamorphic aggregates, occurring in this association not only in the inner zones but also in the mines up Silver Creek. In certain associations, quartz may be locally common.

Some of the metamorphic aggregates in the Leadville Limestone and also in the basal Hermosa as far east as the southwest base of Nigger Baby Hill are very fine grained. Some masses, which are hard, dense, and dark gray to dark purplish gray, contain fine detrital quartz silt in a groundmass of metamorphic minerals, including varying combinations of fine-grained potassium feldspar, albite, andalusite, quartz, hornblende, magnetite, phlogopite, muscovite, epidote, tourmaline, and sphene. This material grades, partly along borders or along cracks, to dense pale-gray or pale-greenish zones that are predominantly fine-grained potassium feldspar, but they also contain varying amounts of calcite, clinozoisite, epidote, chlorite, actinolite, and sphene. Pockets, or crosscutting veinlets, of coarser material include the same minerals as in the pale fine-grained aggregate, as well as other common metamorphic minerals, such as diopside-hedenbergite and garnet. A common association has garnet in the centers of vuggy pockets and epidote, clinozoisite, or diopsidehedenbergite in the bordering zone that is transitional to the finer grained massive material. Such garnet pockets are commonly at the marble contact on the outer edges of the finer grained masses. Where garnet is not present, epidote, clinozoisite, or actinolite may occupy the borders of this finegrained aggregate.

Another pale-gray dense phase, resembling chert, was X-rayed in powder form by Brian J. Skinner, who reports it to be composed largely of fine muscovite and illite (oral commun., 1967). In some of the baked siltstones occurring in the metamorphosed zone as far east as the New Demon mine and bordering a porphyry dike in the Blaine tunnel of the Rico-Argentine mine, the argillaceous matrix has been converted in part to fine-grained biotite.

Chalcopyrite and pyrite are widely distributed as small blebs in the metamorphic aggregates. Sphalerite and galena are less common as disseminated blebs, but they occur in replacement bodies along later channels.

The list of minerals present in the contact metamorphic zone is long, but most of the minerals not already mentioned are of minor significance. All the minerals found are discussed in the section on mineralogy of the ore deposits (p. 58-71).

\section{STRUCTURE}

The dominant structure of the Rico district is a faulted dome roughly 10 miles in diameter, centered just east of the monzonite stock. The rigidity of the rocks was such at the time of doming that much of the accommodation to the structural stresses was by normal faulting and tilting of blocks. Thus, the highest structural element in the Dolores Valley, on the eastward prolongation of the stock, is a horst block containing the Precambrian rocks. The major faults in this area run generally east-west, parallel to the elongation of the stock outcrop. The displacement on these faults in general augments the displacement produced by the quaquaversal dips. The structural displacement at the center of the dome is about 6,000 feet vertically, if the projected positions of eroded strata are compared with the positions of corresponding strata in the surrounding plateau 4 miles to the north and 5 miles to the south.

In addition to the crosscutting faults, there are numerous bedding faults. Those between massive limestones and adjacent shales in the Hermosa Formation are of considerable economic interest because they commonly afforded ingress of ore-bearing solutions to sites favorable for ore deposition. Such faults record displacements that may be considerable on the one hand or negligible on the other, and no clearcut criterion exists for distinguishing the difference. They are easily overlooked in underground mapping. Some of the richest ores in the early days of the Rico district were on bedding breccias in the lower Hermosa of Newman Hill. These may have had a more complex origin than as simple fault breccias (Cross and Spencer, 1900, p. 107-112).

\section{FAULTS}

Underground mapping shows a myriad of faults. Most are of small displacement, but the character of the fault as seen in an underground intercept may bear little relation to its displacement. Thus, the Blackhawk fault in the Rico Argentine workings is nearly everywhere an impressive vein, generally 3-10 feet thick, containing quartz, gouge, pyrite, calcite, and commonly some sphalerite or galena, yet it retains this character where the displacement may be less than 50 feet. The Princeton fault, on the other hand, is an unimpressive 2-12 inches of tight gouge where its displacement may be as much as 1,700 feet. Many faults seen in only a single intercept die out within a few tens or hundreds of feet, and thus have little significance. Their displacement is commonly indeterminable, but small. Other faults, no more impressive in appearance, may be traced 
through several mine workings or projected to the surface where they may be responsible for considerable displacements.

Most of the faults are of normal displacement, but a few are steeply reverse. The Princeton fault shows a large normal displacement at a notably low angle of dip.

Presumably, small insignificant faults are abundant throughout the district, but, in the absence of underground workings, they remain unrecognized. In the following pages, only the more important faults will be discussed, particularly those that account for considerable displacement, recognizable at the surface.

An impressive group of major faults lies along the north side, or prolongation of the north side, of the horst block on which the structure at Rico is centered. These faults have in common an easterly trend and downthrow on the north. The group includes the Last Chance, Nellie Bly, Blackhawk (after junction with the Last Chance), Honduras, 210 Drift, Hidden, and Alaskite faults. Those on the south side of the horst are fewer and do not have the systematic pattern of the north side.

\section{LAST CHANCE FAULT}

The Last Chance fault follows a general east-west course along the north side of the Precambrian horst block north of Rico. It is named (Cross and Spencer, 1900 , p. 119) for the Last Chance tunnel on the south side of Nigger Baby Hill, where the fault passes near, or through, one of the tunnel portals.

For 1,000 feet east of the Last Chance tunnel, the fault, though nowhere exposed, must bring the Uncompahgre Quartzite on the south into juxtaposition with the lower Hermosa on the north. The vertical displacement is at least 1,200 feet. Either the main fault or a closely adjacent subsidiary break was followed westward by the west prong of the Last Chance workings for 200 feet from the portal (pl. 2B). In this segment, the fault strikes N. $85^{\circ}$ $\mathrm{W}$. between porphyry walls, is nearly vertical, and consists of a maximum of 6 inches of gouge and quartz. Two nearly parallel faults in the same system are cut by the other prong of the Last Chance tunnel, one 47 feet north of the previously indicated fault and dipping $85^{\circ} \mathrm{S}$. between porphyry walls, and the other, only 10 feet farther north and dipping $55^{\circ} \mathrm{S}$. between porphyry on the south and Hermosa limestone on the north. The northernmost fault zone is the thickest (maximum 30 in.), but its position and strike (N. $80^{\circ}$ W.) take it slightly out of line with the general course of the Last Chance displacement. These faults may well illustrate the situa- tion wherein much of the displacement antedated the porphyry, but final movement postdated it.

The fault is concealed for nearly half a mile westward from the Last Chance workings. On the west side of Nigger Baby Hill it is split into two or three major prongs and several minor ones. At the level of the Nora Lily main tunnel, the southern of two major prongs 100 feet apart brings the Precambrian greenstone on the south into juxtaposition with a sliver of Uncompahgre(?) Quartzite on the north, whereas the northern prong brings this quartzite up against latite porphyry, intruded into lower Hermosa strata, farther north. The Nora Lily workings, in the 400 feet of tunnel formerly accessible, follow a subsidiary break of the fault system, dipping steeply south, within the porphyry and just north of the second major fault. As elsewhere, the porphyry may be later than the major part of the faulting. Total displacement across the Last Chance zone here is conjectural because the thickness of the Uncompahgre is not known, but the vertical displacement must exceed 2,000 feet.

West of, and downhill from, the Nora Lily workings, the Last Chance fault is split into three major prongs. At the level of the Nutmeg tunnel, a sliver of Uncompahgre(?) Quartzite only 25 feet wide occurs between the first two prongs on the south, a wedge of porphyry perhaps 200 feet wide at maximum occurs between the second and third prongs, and lower Hermosa strata are to the north of the third prong. The Nutmeg tunnel follows a nearly vertical quartz vein $11 / 2$ feet thick on the middle prong. Displacement is profound between the greenstone block south of the Last Chance fault and lower Hermosa strata beyond the porphyry to the north of it, but whether the porphyry preceded or followed the faulting is not revealed in the poor exposures.

West of the Dolores River, two major prongs of the fault enclose a sliver of Uncompahgre(?) Quartzite to a maximum width of about 160 feet. The situation is thus similar to that at the Nora Lily workings. Exposures are poor, and the fault pattern has to be surmised from relatively few outcrops.

The west end of the Last Chance fault zone may be terminated by a wedge-shaped junction with the Smelter fault that forms the opposite (south) side of the Precambrian horst block. Exposures are too poor in the area of junction to determine whether either of the bounding faults extends into the block of Hermosa strata on the west.

Cross and Spencer (1900, p. 120) conjectured that the east end of the Last Chance fault may join 
the Blackhawk fault on the south side of Silver Creek. Exposures in the Blaine tunnel of the Rico Argentine mine indicate that this is true. Although the actual underground junction is not revealed, a prong of the 102 drift southwest from the main tunnel cuts three faults in a 19-foot-wide zone whose position and trend are in line between the Last Chance fault to the west and a major curve in the Blackhawk fault beyond which the displacement is greatly increased (pl. $3 C$ ). Projection upward from the underground indicates that the junction on the surface comes at the bend of the Blackhawk fault near the portal of the Log Cabin (Blackhawk) tunnel (pl. 1). Of the two outside bounding faults in the Last Chance zone as cut underground, the north fault is vertical and the south one dips northnortheast at $58^{\circ}$; they consist, respectively, of 4-6 inches of gouge, and 2-3 inches of gouge, quartz, and a little pyrite. The third fault strikes diagonally between the other two, dips $60^{\circ} \mathrm{N}$., and consists of 1-4 inches of gouge. Unless there are other faults not reached by the drift prong, which extends 22 feet southwest of the southern fault in this zone, a total vertical displacement of about 1,500 feet is accomplished in these three faults. The horizon on the south side may be close to the base of the Hermosa.

There is also a good possibility that the extreme east end of the Last Chance fault, just before it joins the Blackhawk, is represented in two closely adjacent quartz veins cut in the Blaine tunnel 150 feet southeast from the mouth of the Honduras drift. Failure of the Blaine tunnel to stay on the Blackhawk fault immediately to the north makes it uncertain whether these veins, 6 inches to 2 feet thick and containing gouge and pyrite, are in the Last Chance fault zone just before its junction with the Blackhawk inside the wall to the east, or represent the combined faults just after junction inside the wall to the west. The first interpretation appears more probable (pl. $3 C$ ).

\section{SMELTER FALLT}

The Smelter fault, named (Cross and Spencer, 1900 , p. 120) for the Grand View smelter once located on the east bank of the Dolores River near the present bridge north of Rico, bounds the south side of the Precambrian horst block. It follows a general east-west course but is somewhat more sinuous than the Last Chance fault on the north side. Over most of its course the fault is concealed by surface debris, and only its general position can be surmised from the distribution of the rocks on both sides. At its west end it swings northwest to form a wedge junction with the Last Chance fault about 450 feet north of the Black Wonder mine. Its east end terminates against the Silver Creek fault.

The Smelter fault is cut near the breast of the middle Falcon tunnel, at a point 522 feet N. $56^{\circ} \mathrm{E}$. from the portal. The fault here strikes $\mathrm{N} .75^{\circ} \mathrm{W}$. and dips $75^{\circ} \mathrm{SW}$., separating the Larsen Quartzite on the south from the Uncompahgre Quartzite on the north. The fault is here virtually parallel to the upturned bedding of the Larsen Quartzite and is accordingly obscure. No workings of the Falcon mine extend northward from the portals of the three levels far enough to intersect the fault in this direction. Underground mapping shows that a fault that Cross and Spencer (1900, p. 122) mistook for the Smelter fault at the portal of the (upper) Falcon tunnel is actually a small break south of the main fault, showing displacement in the opposite direction.

Vertical displacement on the Smelter fault probably exceeds 1,500 feet from the west end east to the junction with the Futurity fault. For the next 400-500 feet, in the segment north of most of the Falcon workings, the displacement may reverse, the north side down, though so little is known of the north side that the stratigraphic horizon is highly conjectural. Farther east, where the Uncompahgre Quartzite forms the north side, the displacement is probably a few hundred feet, up on the north.

\section{FUTURITY FAULT AND RELATED FAULT TO EAST}

The Futurity fault is herein named from its former exposure in the Futurity tunnel. The tunnel is caved and inaccessible, but copy of a map of unknown authorship was presented to the author by the management of the Falcon Lead Mining Co., showing a fault at 250 feet N. $40^{\circ} \mathrm{E}$. from the portal of the tunnel. The fault trends N. $79^{\circ} \mathrm{W}$., dips $80^{\circ}$ NE., and separates schist on the south from "sandstone" on the north. The necessity for this "hypothetical" fault was recognized by Cross and Spencer (1900, p. 122), who showed it on their areal map (pl. 22) trending about N. $10^{\circ} \mathrm{W}$., beneath concealing wash and talus. The position and more westward trend shown on the areal map accompanying the present report (pl. 1) is nearly in conformity with the information from the Futurity tunnel, modified to some extent from the geologic relations a short distance south of the Nora Lily workings.

A second diagonal fault across the horst block is shown (pl. 1) joining the Last Chance fault at the Last Chance mine. The necessity for this "hypo- 
thetical" cross fault was also recognized by Cross and Spencer $(1900$, p. 122$)$, who showed it trending nearly north-south. The more easterly trend shown on plate 1 takes cognizance of the porphyryquartzite relations as mapped on the surface and underground in the vicinity of the Last Chance portal, and also of the intersection of what is believed to be Uncompahgre Quartzite on the footwall of the Smelter fault near the breast of the middle Falcon tunnel northeast of its portal.

\section{NELLIE BLY FAULT}

The Nellie Bly fault, which is nearly parallel to, but a few hundred feet north of, the Last Chance fault, was named by Cross and Spencer (1900, p. 118) for the Nellie Bly tunnel on the southeast slope of Nigger Baby Hill a few hundred feet southeast of the crestline of the spur. However, the fault that accounts for the large displacement that they recognized is not the one that they surmised, which crosses the upper Nellie Bly tunnel 20 feet from the portal, but is a little farther north. Nevertheless, this fault to the north was undoubtedly crossed by the lower (and longer) Nellie Bly tunnel, now caved, so that the name is still appropriate. The fault is cut at a considerably lower altitude at the breast of the No. 5 level of the Yellow Jacket mine and, 106 feet higher, is followed along a crosscut near the end of the No. 4 level (pl. 2). In these underground intercepts the strike is N. $80^{\circ} \mathrm{E}$. and the dip is $60^{\circ} \mathrm{NW}$. as projected between the two tunnel levels. When projected to the surface, this dip fits very well with the permissible surface position of the fault located with reference to certain limiting rock outcrops. The vertical displacement on Nigger Baby Hill is about 900 feet, down on the north. The north side is in the hanging wall of the Princeton fault, which lies to the north and terminates against the Nellie Bly fault on the west slope of the hill (pl. 1).

West of the Dolores River, the Nellie Bly fault runs up Aztec Gulch, crossing from the south to the north side of the gulch a short distance below the Aztec mine workings. The fault vein is explored by these workings but is not exposed any farther west. In the mine and on the surface down-gulch from the mine, dip on the fault is $65^{\circ}-75^{\circ} \mathrm{N}$.

Between the exposures on the two sides of the river, the Nellie Bly fault is concealed by surficial deposits over a length of about 0.6 mile (pl. 1). Although the rock outcrops in the structural blocks to the north and south of the fault are too small for exact stratigraphic recognition, the best appraisal is that the displacement on the fault reverses in the footwall of the Princeton fault and is down a few hundred feet on the south (pl. 1, section $\left.A-A^{\prime}\right)$. Whether this reversal persists into the Aztec Gulch area is conjectural. Possibly movements in different segments of the fault may have been in different directions at different times.

East of the Nellie Bly tunnels, displacement on the fault decreases rapidly. Ransome $(1901$, p. 384) surmised that the Nellie Bly fault crossed the [upper] Iron Mine tunnel at about 480 feet from the portal, though "careful search for this fault, underground, failed to satisfactorily demonstrate its presence." The east end of the faulted zone near its intersection with the Blackhawk fault was cut in the long crosscut from the St. Louis tunnel to the Rico Argentine workings on Silver Creek, and also on the 400 and 300 levels above and on the 600 level below. In this ground the fault horsetails into two or three branches, largely of reverse displacement, on the St. Louis (500) and 300 levels of the Rico Argentine mine; but it is a single fault of reverse displacement at the intermediate 400 level where the fault is offset about 13 feet by a bedding fault (fig. 2). Several of the branches have bent to a northeast strike in the ground approaching the Blackhawk fault (pl. 3), but strikes and dips on individual branches may vary notably within short distances. Some of the major segments of the fault in this ground are tight obscure breaks that cannot be recognized even when specifically searched for in the workings, yet the gaps in the stratigraphic sequence are definite. There are probably other bedding faults similar to the one exposed on the 400 level which slide the hanging-wall block downdip to the north, thus breaking the various branches of the fault into disjunct segments, individually of steeper dip than indicated on the generalized section shown in figure 2. Some segments of the fault have acted as obscure limiting surfaces against which several massive sulfide ore bodies terminated abruptly. The overall displacement is about 120 feet, down on the north.

A fault that at first glance appears to be in an eastward prolongation of the Nellie Bly fault zone beyond the Blackhawk fault crosses the east prong of the St. Louis crosscut, 305 feet north-northwest from the projection of the Argentine shaft (pl. $3 G$ ). This fault shows a trend similar to some of the branches west of the Blackhawk and is equally obscure and irregular in detail. It offsets at least 50 feet to the north on the east side of the Blackhawk, though no correlation can be established with any definite branch on the west side. The displacement on this fault is about $80-90$ feet, down on the north. 


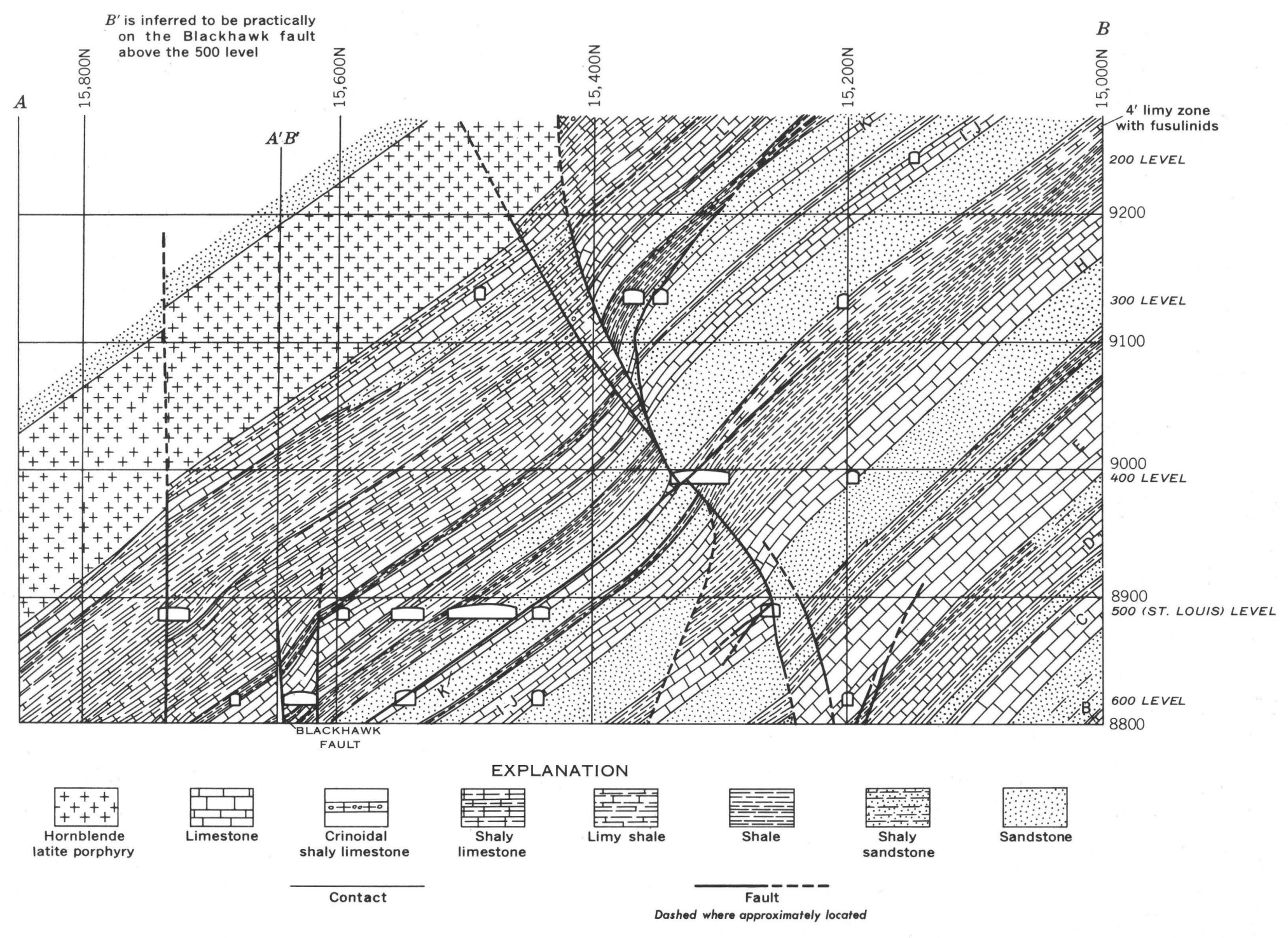

FIGURE 2,-Cross section of Nellie Bly fault zone in the Rico Argentine mine on line $A-B$ on plate 3 . Because the section may be somewhat inclined to the strike normal of both faults and strata, the dips shown may be somewhat less than true dips. 
The relations suggest at first glance that the Nellie Bly fault is earlier than the Blackhawk. However, the two may be nearly contemporaneous, for the Nellie Bly has evidently been disturbed by proximity to the Blackhawk so that it has horsetailed into separate branches and changed direction. These features are not believed to be due to modification of a throughgoing fault by later crossfaulting, but rather to be related to complex stress conditions prevailing at the time of initial rupture. The fault of the Nellie Bly system east of the Blackhawk fault may well be an independent break, produced contemporaneously with the other faults.

The Nellie Bly fault is marked by a quartz vein, 1-6 feet thick, in the Aztec mine workings and on the nearby surface down the gulch from the Aztec portals. On the No. 5 level of the Yellow Jacket mine, the fault is a gouge zone containing calcite and a little pyrite, galena, and sphalerite. On the No. 4 level, the fault zone consists of two virtually parallel faults 6-11 feet apart containing gouge, quartz, and locally sulfides, with squeezed and broken ground between them. On the west side of Nigger Baby Hill, however, the fault is near or on a porphyry dike, dipping $70^{\circ} \mathrm{N}$., at the same levels as the Yellow Jacket underground exposures. At the exposures in the Rico Argentine mine, the fault filling generally varies from a quarter of an inch of calcite between slickensided walls to 4 inches of calcite, fine pyrite, and gouge, locally containing sphalerite and galena; but in places the fault is so tight as to be unrecognizable.

\section{YELLOW JACKET FAULT}

A fault between the Last Chance and Nellie Bly faults and known only from exposures in the southernmost workings of the Yellow Jacket (Phoenix) mine. No $31 / 2,4$, and 5 levels (pl. 2) is herein named for that mine. It is nowhere indicated on the surface, but is shown on plate 1 as projected from the underground exposures. Average strike is N. $81^{\circ}-82^{\circ} \mathrm{W}$. on the three levels, and the dip is $45^{\circ}-$ $90^{\circ} \mathrm{SW}$. in different places, averaging perhaps $70^{\circ}$. Probably the south side is down, but the displacement cannot be estimated because the stratigraphic horizon has not been identified on the south side. The fault appears to be of considerable importance because the direction of bedding dip on the No. 4 level is reversed across it, from northeast at $25^{\circ}-$ $40^{\circ}$ on the north side to southwest and south at $40^{\circ}-65^{\circ}$ on the south side (pl. $2 A$ ). Closely adjacent and roughly parallel subsidiary faults show on all three levels, so that the fault is more properly a zone. At one place on the No. 5 level, three fault veins occur in this zone within a width of 30 feet, each vein consisting of 2-3 inches of quartz containing some pyrite. Elsewhere on this level, all the faulting appears concentrated in a gouge zone 5 feet thick. On the No. $3 \frac{1}{2}$ level near the portal, the fault zone is a breccia of sandstone and some shale fragments over a maximum width of 40 feet, with pockets of sphalerite, galena, and pyrite partly replacing some of the fragments. Strikes and dips on the south side of the fault shown on plate 1 were not taken at the surface but are projected from the underground workings.

\section{SILVER CREEK FAULT}

The Silver Creek fault trends northeast, following rather closely the bed of Silver Creek from the South Park mine and fault northeast to the Last Chance fault. It is nowhere well exposed, but in the southwest half of this stretch, its position can be plotted closely between Uncompahgre Quartzite outcrops on the southeast and Larsen Quartzite and Hermosa Formation outcrops on the northwest. Brecciated quartzite adjacent to the fault is exposed in a few places. In the northeast half of its course, the Silver Creek fault is between Uncompahgre Quartzite on both sides, though there are no outcrops along the fault or anywhere near it on its northwest side. Postulation of the fault in this stretch is not compelled by outcrop distribution, but its presence is surmised from the considerable displacement on the fault to the southwest, from the reentrant angle on the west between the quartzite blocks on the two sides (pl. 1), and from the lack of quartzite exposures along the creek on the line of the fault, presumably because of the ease of erosion in highly shattered quartzite along the fault. Displacement along the southwest half of the fault cannot be closely estimated but must amount to several hundred feet, up on the southeast. In the northeast half of the fault, the direction and amount of displacement are not determinable.

A small fault which is southwest of the Silver Creek fault and directly in line with it, but which displaces the ground in the opposite direction, follows the southeast bank of Silver Creek opposite Knob Hill (pl. 1). It drops the Newman Hill sill on the southeast side against underlying shales and limy shales on the northwest side. This is the fault segment to which Cross and Spencer $(1900$, p. 124) applied the name "Silver Creek fault," but it does not have the displacement that they ascribed to it because they failed to recognize the roughly parallel Knob Hill fault, 300 feet to the north. Our interpretation of these different faults and cross faults 
is reflected in the mapping shown on plate 1 , which shows no continuity between the two segments along Silver Creek. The fault pattern at, and downstream from, the South Park mine is admittedly equivocal because of poor outcrops. However, the porphyry that forms the south wall of the South Park tunnel is believed to be the sill that crops out at the portal of the Ahkeah tunnel rather than the much thicker Newman Hill sill. The base of the sill rises above the floor of the South Park tunnel at 100 feet from the portal and ascends at a low angle in the remaining 115 feet of the tunnel that was accessible in 1931. This position of the sill base is in harmony with that of the sill on the northwest side of the creek and not with the base of the Newman Hill sill as surmised from developments within the Hibernia tunnel (Ransome, 1901, p. 351). Transferral of the name "Silver Creek fault" to the segment northeast of the South Park mine seems justified in view of the far greater displacement on this segment and the lessened importance of the segment southwest of the mine.

FAULTS SOUTHEAST OF SILVER CREEK BOUNDING THE QUARTZITE MASS

The mass of Uncompahgre Quartzite southeast of Silver Creek is doubtless in fault contact with the Newman Hill porphyry sill which is near the base of the Hermosa, though the contact is nowhere seen. The fault is mapped (pl. 1) at the highest uphill outcrop of the quartzite against porphyry float from above and is approximately in line with the base of the porphyry as projected from Allyn Gulch. Vertical displacement on the fault is probably several hundred feet down on the southeast, but uncertainty as to the occurrence and thickness of the Ouray and Leadville Limestones and Larsen Quartzite in this area makes any closer estimate impossible.

The quartzite is presumably bounded on the northeast by lower Hermosa strata, though there are no present exposures of such strata short of Allyn Gulch. Cross and Spencer (1900, p. 125) stated that the boundary is a fault vein trending $\mathrm{N} .15^{\circ} \mathrm{W}$. at (within?) the Laxey mine, and this information has been taken into account in the mapping (pl. 1). At the southwest end of the quartzite mass a fault of displacement comparable to that of the fault at the Laxey mine must separate the quartzite from the lower Hermosa strata exposed within the South Park tunnel along its north wall.

$$
\text { SOUTH PARK FALLT }
$$

The South Park fault was followed for several hundred feet by the South Park tunnel. It is a steep reverse fault of not more than 100 feet throw, striking N. $72^{\circ} \mathrm{W}$. and dipping $77^{\circ} \mathrm{NE}$. in the mine. The basal Hermosa sandstone and shale on the north are dragged down against porphyry on the south which is undoubtedly the sill exposed at the Ahkeah mine, below the thick Newman Hill sill. The base of the porphyry, dipping gently toward the portal, was reached at about 100 feet from the portal. The fault was also cut in a short tunnel on the north side of Silver Creek where it dips $70^{\circ} \mathrm{NE}$. in sedimentary strata just beneath porphyry sills, and it apparently extends just south of the Ahkeah portal. Cross and Spencer (1900, p. 123) believed that the fault extended northwest across the low spur of Nigger Baby Hill and joined the Smelter fault. However, the continuity is equivocal, and the fault may not extend far beyond the Ahkeah mine.

In the South Park tunnel, the fault zone contains a maximum of 18 inches, though generally less than 12 inches, of gouge and banded quartz; the adjacent shale is impregnated with pyrite and locally a little black sphalerite and galena. In the short tunnel north of the creek, the 18 inches of quartz along the fault zone contains some specularite. Here, a second quartz vein, 1 foot thick and nearly vertical, strikes parallel to the South Park fault and is about 30 feet south of it. This vein is also recognizable on the surface at the creek crossing where it shows minor displacement in the same direction as the main fault.

\section{KNOB HILL FAULT}

A poorly defined fault that crosses the south slope of the knob around which branches of the road wind at the start of their climb up Silver Creek is herein named the "Knob Hill fault." This fault is recognized chiefly from the prevalence of porphyry on its north side and of lower Hermosa shales and sandstones on its south side. Most of the information pertinent to mapping of the fault is yielded in the roadcuts, but scattered exposures along the creek and at old prospect and bunker cuts complete the picture. The porphyry on the north side of the fault is chiefly the sill that crops out at the Ahkeah tunnel, whose stratigraphic position is below the thick Newman Hill sheet; the porphyry that caps the knob (pl. 1) is believed to be a slightly higher sill, though the intervening strata are not exposed. This higher sill is exposed south of the fault at a lower level in the old railroad cut where it is thin and lenticular.

The Hermosa strata exposed in the roadcuts and streambanks to creek level on the south side of the fault are predominantly shales of very different aspect from the prevailing dolomites and sandstones 
of the section exposed below the porphyry sill in the Ahkeah tunnel (see p. 21-22). Hence, this section lies stratigraphically above the Ahkeah sill, and the downthrow is on the south. Throw on the fault cannot be determined exactly, but south of the knob it amounts to perhaps 50-75 feet.

The Knob Hill fault partly accounts for the displacement for which Cross and Spencer (1900, p. 124-125) postulated a concealed fault, their Silver Creek fault, farther southeast along the bed of Silver Creek. Although there is some concealed minor faulting along the creek bed, the necessity for a major fault is now largely obviated.

\section{SANDSTONE MOUNTAIN FAULT}

The Sandstone Mountain fault crosses the mountain for which it is named in a direction averaging N. $75^{\circ}$ E. The importance of the fault is chiefly negative in that it and small fractures allied with it disrupt and complicate what would otherwise be an unbroken and well-exposed standard stratigraphic section for the Rico district. The displacement is down on the north and amounts to about 50 feet on top of the ridge, but laterally on both sides the displacement is augmented by that on two faults that join the Sandstone Mountain fault from the northwest. At the highway along the Dolores River, the throw is about 215 feet.

The diagonally ascending cliffs in the upper Hermosa east of the river at Burns are broken by a fault that is approximately in line with the Sandstone Mountain fault west of the river. The throw is down 70 feet on the north. Although this might at first appear to be an extension of the Sandstone Mountain fault, the Blackhawk fault intervenes, trending approximately at right angles. The strata along the northeast side of the Blackhawk fault are apparently unbroken in the area where an extension of the Sandstone Mountain fault should cross, hence, the fault east of the river is believed to be separate and probably dies out to the west before the Blackhawk fault is reached.

\section{PRINCETON FAULT}

The Princeton fault has one of the greatest displacements of all the faults in the Rico district, but it is one of the most unimpressive of fissures at the few places where it has been observed underground. The Princeton shows remarkably low dip. Surface outcrops are in most places deeply covered by landslide and talus, and only in the area east of Strawberry Spring at the north side of CHC Hill are there enough outcrops to place the position of the fault fairly accurately from surface mapping. Ne- cessity for the fault, to account for obvious and large displacement of structural blocks on opposite sides of the CHC Hill landslide area, was recognized by Cross and Spencer, but their hypothetical "Telescope Mountain fault" (Cross and Spencer, 1900 , p. 126-128), invented to supply this need, trends more to the east than the true position of the fault. They mapped correctly (their pl. 22) the northeast end of the major fault on the ridge slope northwest of Telescope Mountain, but underground developments in and under CHC Hill since 1900 show that they failed to recognize the magnitude of this fault's displacement in the vicinity of Strawberry Spring. The fault was named at a later date by company geologists of the St. Louis Smelting \& Refining Co., presumably from exposures in the old Princeton mine whose caved portal is in the footwall of the fault southwest of the Wellington portal.

The Princeton fault delimits the ore deposits of CHC Hill on the southeast, dropping the middle Hermosa limestones that are mineralized in the Wellington and Mountain Spring workings to a position farther southeast well below the level of the St. Louis tunnel, which is more than 600 feet below the Mountain Spring level. The fault has been seen in the underground workings at relatively few places. At the top, it bounds the J and I level stopes above the Wellington tunnel level. On the Wellington level, two intersections were formerly exposed in drifts a short distance east of the Blackhawk fault, and the E bed stope on this level is bounded at its southeast end by the Princeton fault (pl. 2). Altitude on this level is 9,783-9,785 feet. The D Bed stope, 35 feet lower, is also bounded by the fault. There are no known intersections on the underlying Mountain Spring level, but the fault was penetrated at the southeast end of the C level (old St. Louis Smelting \& Refining Co. stope workings) whose position is 136 feet above the Mountain Spring level and 135 feet below the Wellington level. Possibly, other intersections were made in old stopes between the Mountain Spring and Wellington levels and in the Princeton mine, but these workings have long been caved. The next and lowest intersections are in the long crosscut that runs from the St. Louis tunnel southeast to the Argentine shaft at a point about 400 feet from the main St. Louis adit and in the minor Iron Rod workings above the level of this crosscut. The fault was followed by short drifts both to the northeast and southeast from the crosscut. Altitude of the crosscut level is about 8,905 feet, and the Iron Rod level is 103 feet higher.

All exposures of the Princeton fault that have been accessible since 1930 have been in the hang- 
ing (northeast) wall of the Blackhawk fault. Trend of the Princeton fault on the Iron Rod level is N. $50^{\circ} \mathrm{E}$. but may be influenced by proximity of the Blackhawk fault which projects in the wallrocks only 60 feet from the nearest Princeton fault exposures. On the Wellington level, the Princeton fault trends N. $84^{\circ} \mathrm{E}$. at its southwest end near the Blackhawk fault, but away from the fault it swings to about N. $44^{\circ} \mathrm{E}$. across the two prongs of the $\mathrm{E}$ bed stope. When projected to the surface, the fault fits the surface mapping very well northeast of Strawberry Spring.

Projection from the St. Louis to the Wellington level shows a fault dip of $35^{\circ} \mathrm{SE}$. This is also the maximum dip observed in the Wellington workings and adjacent sub levels. Some dips observed in the $\mathrm{E}$ bed stope of the Wellington are as low as $27^{\circ}$, and projection from the $\mathrm{D}$ bed to the $\mathrm{E}$ bed stope indicates $28^{\circ}$. The fault probably steepens in depth, as measurements of dip on the St. Louis level show $45^{\circ}$, and projections from here to the Iron Rod level indicate $47^{\circ}$.

Calculation of the displacement is complicated by the low angle of the fault and a correspondingly large amount of heave, and by uncertainty as to the exact horizon of the 180 feet of strata cut in the hanging wall on the St. Louis level. These strata are believed to be most probably in the Rico Formation. Calculating on this probability, the throw of the fault is about 2,100 feet.

The actual fault zone may show as little as 1 inch of gouge, though 2-6 inches of gouge is its general expression, and a maximum of 18 inches is reached locally on the St. Louis level. The gouge is not commonly mineralized, but in places it may carry a little quartz, pyrite, sphalerite, galena, or rhodonite. The average appearance of the fault is no more impressive than hundreds of small fissures on which only a few feet of displacement can be demonstrated.

Intersection of the Princeton with the Blackhawk fault has not been cut in any of the mine workings. The Blackhawk fault projects across the Princeton without offset, whereas there is evidence that it offsets and is thus later than the Princeton fault. An old map prepared by geologists of the St. Louis Smelting \& Refining Co. shows an intercept of the Princeton fault in the footwall of the Blackhawk fault in the southernmost workings of the Wellington level which were caved before 1930. Projection of this fault to the Blackhawk indicates an offset of about 350 feet to the northwest at the crossing into the hanging wall of the Blackhawk, which is the expected amount and direction of offset if displace- ment on that fault is normal. This offset is shown projected to the surface in plate 1 . Although the Princeton fault is nowhere exposed at the surface on the southwest side of the Blackhawk fault, limiting outcrops fix its location within relatively narrow limits and show that it changes trend on crossing the Blackhawk, from about N. $46^{\circ}$ E. northeast of it to about N. $26^{\circ}$ E. southwest of it. The Princeton fault presumably terminates on the southwest against the Nellie Bly fault.

\section{BLACKHAWK FAULT}

The Blackhawk fault is of considerable economic interest because much of the mineralization in $\mathrm{CHC}$ Hill and in the Rico Argentine mine workings up Silver Creek appears to be spatially related to it. The fault is named for the Blackhawk mine (now part of Rico Argentine mine), whose Log Cabin level intersects the fault vein at a low angle a couple of hundred feet from the portal and follows it for 250 feet. Northwest of this portal the fault follows a general northwesterly course, varying in detail but averaging about N. $36^{\circ} \mathrm{W}$., and can be traced, partly through underground workings in CHC Hill, for about $21 \frac{2}{2}$ miles, to a point beyond the Dolores River. At its end it splits up into at least three branches. The fault is concealed under the landslide debris of CHC Hill, except for a short stretch northwest of the Logan tunnel where the fault vein crops out at one spot. Southeast from the Log Cabin portal, the trend of the fault is influenced by that of the Last Chance fault which joins it from the west near this portal and averages about S. $45^{\circ} \mathrm{E}$. in the additional mile that the fault has been traced to the limits of the mapped area. This trend is partly determined by the topography of the outcrop area, and the true strike is even more easterly than indicated, averaging S. $60^{\circ} \mathrm{E}$. in the 2,800 feet the fault is followed in the Blaine tunnel. In this stretch the fault breaks up into several branches.

The displacement of the Blackhawk fault is generally down on the northeast from 50 to 700 feet, depending in part upon the displacement of intersecting faults, but locally it is down on the southwest. West of the Dolores River at Burns, the throw on the southwest prong is 50-70 feet, down on the rortheast. East of the river and southeast of the junction with the Sandstone Mountain fault, the throw, here all on one break, is about 300 feet. Near the Logan tunnel the throw is about 450 feet, and at the crossing of the Mountain Spring tunnel, about 250 feet. As measured on the surface in the lower part of Uncle Ned Draw 900 feet northwest of the Argentine shaft, the throw is 90 feet. On the St. 
Louis tunnel level, 350 feet northwest of the Argentine shaft projection, the throw is probably less than 20 feet, and near the Argentine shaft it is 0-43 feet at different places and levels. Just south of the intersection with the 210 Drift fault which joins the Blackhawk from the northeast about 300 feet from the Log Cabin portal, displacement on the Blackhawk fault is reversed, up on the northeast about 225 feet. Presumably, this reversal carries to the Log Cabin portal. There, the Blackhawk fault is joined by the Last Chance fault from the west, and its displacement is restored to the general pattern of down on the northeast and greatly augmented by the large displacement on the Last Chance fault. The throw cannot be calculated very closely but must approximate 700 feet east of the Wildcat tunnel.

Unlike most other major faults of the Rico district, the Blackhawk fault is generally marked by a thick vein of quartz which carries some pyrite and locally calcite and sulfides other than pyrite, though rarely in economic amounts. The vein in most places is 1-17 feet thick, commonly 3-10 feet. In the Pigeon tunnel, however, the fault zone is about 35 feet thick, and Cross and Spencer $(1900$, p. 116) quote one underground thickness near here of 50 feet. Some gouge is present, but it may be largely or wholly replaced by the quartz. Along stretches in the Blaine tunnel and the underlying 200 and 300 levels north of the junction with the Last Chance fault, the fault splits around narrow horses that may be as much as 20 feet wide and more than 100 feet long. Throughout its total length are numerous small splits that branch off the main fault at acute angles.

Dip of the Blackhawk vein is generally $70^{\circ}-90^{\circ}$ NE. However, at the several intercepts observed in the Mountain Spring and Wellington tunnels which cross the fault at the south end of a prominent bow in strike to the west, the dip is only $40^{\circ}-65^{\circ}$; in the Pigeon tunnel farther northwest, near where the strike swings back to a more northerly direction, the dip of the fault zone averages $65^{\circ}$. In those segments of the fault where the displacement is low or reversed, the direction of dip is also generally reversed $-80^{\circ}-85^{\circ} \mathrm{SW}$. at the drift crossing on the St. Louis level 350 feet northwest of the Argentine shaft projection, and $73^{\circ}-84^{\circ} \mathrm{SW}$. as projected between the 200 and 300 levels of the Rico Argentine mine in the block of ground south of the intersection with the 210 Drift fault. In much of the 900 feet between these two places the dip is also steeply to the southwest, $80^{\circ}-90^{\circ}$, though the displacement is down on the northeast. Hence, the fault is steeply reverse over much of this stretch. The dip evidently changes rapidly from place to place in both horizontal and vertical directions, which is in conformity with the sinuosity in detail of the fault strike.

The junction of the Blackhawk with the Last Chance fault is not exposed in the underground workings. On the Blaine tunnel level, the Blackhawk is offset about 25 feet to the east where the Honduras fault vein first branches off from its east side (pl. $3 C$ ) but there is no convincing evidence that the Honduras break is later. Beyond the offset, the Blackhawk vein continues on its regular southeast course for 75 feet along the drift, and at this distance it is cut off by an unimpressive transcurrent fault dipping $46^{\circ} \mathrm{SE}$. The Blackhawk is displaced by this cross fault to the northeast or southwest, probably the former, but outside the drift; within 80 feet more, the continuation of the drift crosses what is believed to be the east end of the Last Chance fault just before it joins with the Blackhawk. The junction must be in the ground between the Blaine and Honduras drifts (pl. $3 C$ ). The fault southeast of the junction is called Blackhawk rather than Last Chance because the thick quartz vein along it is identical in character with the Blackhawk vein farther northwest and is unlike other exposures on the Last Chance fault.

The Blackhawk fault is later than, and offsets, the Princeton fault. Its relation to other faults has not been directly determinable. Thick sills and dikes of the hornblende latite porphyry and a dike of the alaskite porphyry are prominent along parts of the Blackhawk fault, particularly southeast of the junction with the Last Chance fault, which indicates that the main fault zone was at least locally a locus for introduction of igneous material. However, the presence of fault surfaces, gouge, and vein material in the igneous rock attests to much fault movement that is postporphyry. Persistence of the Blackhawk type of intense silicification over the stretch where this fault is combined with the Last Chance fault suggests that at least the last movement on the Blackhawk is also later than the Last Chance. Relative lateness of the Blackhawk fault in the history of geologic events in the district and its sinuosity in both horizontal and vertical detail doubtless opened its channels to movement of late hydrothermal solutions, accounting for its importance as a mineralizing structure.

\section{HONDURAS FAULT}

The Honduras fault was named by the Rico Argentine Mining Co. for Honduras draw, an unlabeled minor draw east of the Argentine tunnel along whose upper and more sharply incised course the 
eastern end of the fault runs. The fault is half a mile long and trends nearly east-west in the hanging wall of the Blackhawk fault, joining this fault about 450 feet southwest of the Argentine tunnel portal. It is cut in the Argentine tunnel (pl. $3 B$ ), and its several splits are cut at several places in the lower lying Blaine tunnel, the major split being followed by the Honduras drift eastward from the junction with the Blackhawk fault (pl. $3 \mathrm{C}$ ). Downward splits are also cut on the 200 and 300 levels (pl. $3 D, E$ ). Displacement is down on the north. In Honduras Draw, the east end of the fault joins the Alaskite fault coming in from the northwest, and their displacements are combined to produce a somewhat larger fault break to the southeast.

Cross and Spencer (1900, p. 119, pl. 22) recognized the faulting in upper Honduras Draw but ascribed it all to one fault which they believed to be the east end of the Nellie Bly fault. Developments in the Rico Argentine mine and particularly along the St. Louis crosscut level (pl. $3 G$ ) indicate that the Nellie Bly fault cannot continue to the southeast across the Blackhawk fault.

The Honduras fault is well defined on the Argentine tunnel level ( $\mathrm{pl} .3 B$ ). It contains $2-8$ feet, but commonly about 5 feet, of gouge, quartz, and pyrite, dipping $70^{\circ}-80^{\circ} \mathrm{S}$. The throw is about 140 feet, down on the north; hence, the break is here a reverse fault. Surface exposures a short distance east of the segment cut on the Argentine level, however, show a dip of $70^{\circ} \mathrm{N}$.

In the Blaine tunnel, 245 feet below the Argentine level, the junction of the Honduras fault with the Blackhawk fault is cut just north of where the Blackhawk joins the Last Chance fault and bends eastward (pl. $3 \mathrm{C}$ ). As the Honduras and augmented Blackhawk faults diverge eastward at only a slight angle and dip in opposite directions, their intersection should plunge eastward at a low angle if the simple Honduras vein of the Argentine level had persisted down the dip. Instead, the Honduras vein approaching the intersection has broken up into several branching splits and locally horsetail zones, each of relatively insignificant aspect, commonly of flatter dip than on the Argentine level, and of irregularly curving strike. For example, the main split followed eastward by the Honduras drift from the junction with the Blackhawk fault starts at S. $67^{\circ}$ E., then bends left to N. $45^{\circ}$ E., and then right to N. $80^{\circ}$ E., all within a length of 500 feet; what is probably the same break lined up in workings beyond 150 feet of uncut wallrock strikes S. $75^{\circ} \mathrm{E}$. This split dips generally south at $40^{\circ}-55^{\circ}$ but steepens near the east end of the nearly con- tinuous stretch to $68^{\circ}-73^{\circ}$, and to $60^{\circ}-90^{\circ}$ in the horsetail zone in the farther remote workings. It is commonly only 1-3 inches thick, but locally is as much as 2 feet of gouge, some calcite, quartz, pyrite, and sparse galena. Near the Blackhawk fault it is 18 inches of quartz, gouge, and a little pyrite. This split crosses and offsets the Blackhawk about 25 feet, but there is no evidence that it is later. West of the Blackhawk fault, it curves northwest along the 107 drift, its dip steepens and then reverses, and within 150 feet of the fault crossing it has become a subsidiary parallel break located only 20 feet within the footwall of the Blackhawk fault. Thus, each of the two breaks influences the other, and they are probably of virtually contemporaneous origin. There are several other splits of the Honduras fault east of the Blackhawk which either diverge from the main split in ground plan or can be assumed to have diverged downward in vertical cross section from the simple break on the Argentine level. Some of these dip northward, and some are obviously sinuous in vertical cross section. It is impossible to determine which of the splits carry the major part of the displacement recognized on the Argentine level.

Some of the westernmost splits of the Honduras fault that are recognized on the Blaine level have joined the Blackhawk fault before the 200 level is reached, about 100 feet below the Blaine level. Others that doubtless belong to the Honduras system are difficult to project between levels because of changing dip or lack of underground workings at critical places. Interpretation and projections are also complicated by the presence of porphyry bodies which may conceal considerable fault movement that preceded their congelation. An undoubtedly major segment of the Honduras system is cut on the 200 level along the north edge of workings 125-200 feet southeast of the $214 \mathrm{drift}$ (pl. $3 D$ ). The strike here is $\mathrm{S} .70^{\circ} \mathrm{E}$., and the dip, $77^{\circ}-90^{\circ} \mathrm{SW}$. The throw is down on the northeast about 150 feet, and thus the fault shows reverse displacement. It consists of 2-8 inches of gouge, calcite, and pyrite. The fault is here only 120 feet from the Blackhawk fault, strikes nearly parallel to it, and displaces the ground in the same direction. To the northwest it has evidently split into two northeastward-dipping branches at the 214 drift and has converged again to a single vertical break across the Rico Argentine dike. Although the break across the dike is occupied by an impressive quartz vein 10-18 inches thick, another break of larger displacement must have run to the southwest along the dike but is no longer evident because this break was preporphyry. The main 
segment of the Honduras fault crosses the 305 raise from the 300 level, which is 120 feet below, and is followed eastward by the 327 drift on the 300 level (pl. $3 E)$.

Minor splits of the Honduras system northeast of the one carrying the major displacement and dipping north-northeast are exposed on the 300 level (pl. $3 E$ ). One, cut in the 304 drift about 25 feet northeast of the main drift, dips $38^{\circ}$ NNE. and displaces the Rico Argentine dike; throw on the west side of the dike is about 40 feet, down on the north-northeast. The same break, or a branch of it, is cut to the east in the 306 drift. Two western branches of this fault, with smaller throw, are cut in the main drift west of the 304 drift, and probably a third branch is represented in a bedding fault near the top of $\mathrm{C}$ bed in a north crosscut (307 drift), 60 feet from the main drift.

Near parallelism of a major segment of the Honduras fault with the Blackhawk fault on the 200 and 300 levels is in contrast with the pronounced divergence in the courses of the two faults on the surface. The surface divergence is due in large part to their opposite dips combined with the topographic effect produced by each outcropping diagonally across a steep slope.

A porphyry dike joins the Honduras fault at an acute angle on the surface and follows for some distance along the north side of the fault. This dike is also present at the east end of the fault exposure on the Argentine level (pl. $3 B$ ). It is questionably present in comparable position in only a short segment of the fault on the Blaine level, but the abundance of sills and dikes in the general vicinity of the Honduras and Blackhawk faults on this level complicates any tracing of individual igneous bodies from higher to lower levels.

\section{ALASKITE FAULT}

This fault is herein named for the alaskite porphyry dike that occupies its western exposures on the southeast side of Silver Creek, a quarter of a mile east of the Argentine shaft. Course of the exposed part of the fault containing the dike curves somewhat but averages about $\mathrm{S} .75^{\circ} \mathrm{E}$. as it rises diagonally across the slope above the wash and talus along Silver Creek. After about 1,000 feet of exposed length, the course bends sharply to the right, averaging about S. $45^{\circ} \mathrm{E}$. for the remainder of its mapped extent, following in part an upper stretch of Honduras Draw. In this draw the fault is joined from the west, and without marked deviation in its course, by the Honduras fault which augments its displacement considerably. The combined displacement is not measurable, but the throw in the lower segment, before junction with the Honduras fault, amounts to perhaps 400 feet, down on the northeast.

The west end of the Alaskite fault is concealed beneath the wash and talus that floors Silver Creek valley, but it may join the hanging-wall side of the Blackhawk fault somewhere between 350 and 900 feet northwest of the Argentine shaft. No fault of any appreciable displacement crosses the outcrop of the Rico Formation in the Blackhawk hanging wall, which places the maximum on the distance from the Argentine shaft; the hanging-wall block within 350 feet of the shaft is cut underground by the east prong of the crosscut from the St. Louis tunnel. It is, of course, possible that the Alaskite fault may die out westward, or its displacement may diminish westward to the extent that such displacement would be unnoticed in the Rico Formation.

\section{DRIFT FAULT}

The 210 Drift fault is herein named for a drift that follows it for $\mathbf{1 5 0}$ feet into the northeast wall of the Blackhawk fault on the 200 level of the Rico Argentine mine (pl. $3 D$ ). Mapping of the fault shown on plate 1 is projected from the underground, as the fault was not recognized on the surface. It is of importance because it displaces the limestones of the middle Hermosa by a large, though varying, amount in the mine workings. The fault, which is recognized only on the northeast side of the Blackhawk fault, has a persistent strike of N. $73^{\circ} \mathrm{E}$. on the Blaine, 200, and 300 levels and is vertical in most places. It projects in the Argentine tunnel close to the portal but was not recognized there. In the middle tunnel of the Rico Consolidated mine, the fault is present at the north side of the stoped ground near the portal where the dip is $70^{\circ} \mathrm{SSE}$. (pl. $3 B$ ), though projection from there to the underlying Blaine level indicates the normal verticality. Downthrow is on the north and is a maximum of 265 feet near the Blackhawk fault, but it diminishes rapidly to the east and is only 20 feet in the Rico Consolidated mine. In some places the fault has split into two or more branches a few feet apart.

The obscureness and tightness of this fault belies its importance, and it could easily be overlooked in routine underground mapping. Although transected at several places on four levels, it has generally been ignored by the mine workings, except for the short drift for which it is named and 150 feet of drifting on the Blaine level (pl. $3 C$ ). The fault filling is generally $1 / 4-2$ inches thick but is 6 inches thick where transected by the 112 drift of the 
Blaine level (pl. $3 C$ ). Commonly, the filling is only gouge, but locally, quartz, calcite, pyrite, or, rarely, galena, are present.

The 210 Drift fault has not been recognized on the 400 level nor in the extensive stopes to the south, though projection from the Blaine, 200, and 300 levels suggests that the fault should have been crossed near the southeast end of the 406 drift (pl. $3 F$ ). Only $\mathrm{E}$ bed limestone is recognized in the 406 and 410 drifts and adjacent stopes. Evidently, the fault was displaced by a later bedding fault that offset it at least 100 feet, relatively to the southeast on the lower side. Such displacement would be similar to that shown by the Nellie Bly fault on the 400 level (pl. $3 F$ ), except that the amount of offset would have to be much greater. Evidence tending to support this interpretation can be found in the stopes south of the 406 drift. Here, slickensides along, or nearly along, the bedding are conspicuous in places at the top of the $\mathrm{E}$ bed limestone, and extensive mineralization of the $\mathrm{E}$ bed in these stopes is further suggestive of structural breaking that could have been produced by bedding faults. Such a bedding fault, containing 6 inches of gouge, shows near the top of the $\mathrm{C}$ bed in the 307 drift of the 300 level (pl. $3 E$ ), approximately where a presumed bedding fault in the shale (unit 14 of the composite section) above the $\mathrm{E}$ bed on the 400 level should project. Intersection of this bedding fault with the 210 Drift fault is in uncut ground, but the surmised relations are indicated in plate $3 E$. A surprising result of these unusual structural relations is that the $\mathrm{E}$ bed at the intersection of the 406 and 410 drifts on the 400 level is almost directly below the $\mathrm{D}$ bed in the $307 \mathrm{drift}$ of the 300 level, whereas their true stratigraphic positions are the reverse of this.

\section{HIDDEN FAULT}

The name Hidden fault is herein applied, for lack of a more suitable name, to an obscure fault mapped on the surface between the Blackhawk and Honduras faults. It is nearly parallel to the Blackhawk, having a trend of about N. $62^{\circ} \mathrm{W}$. where best determined on the surface, but a slight curve at its northwest end projects it into a porphyry dike trending N. $42^{\circ} \mathrm{W}$. The only fault exposed underground that can be correlated with the surface fault is near the southeast end of the Rico Consolidated mine, in an extension of a drift at a slightly higher level along the Honduras vein of the Argentine level (pl. $3 B$ ). This underground exposure is perhaps 15-20 feet south of the unexposed junction with the main branch of the Honduras fault, and shows 6 inches of calcite, gouge, pyrite, and some sphalerite, striking N. $22^{\circ} \mathrm{W}$. and dipping $63^{\circ} \mathrm{NE}$. The southward extension of this underground fault has to curve sharply east to clear workings on the Argentine level to the southeast (pl. $3 B$ ), and in such position it projects acceptably with the surface mapping. The fault must be northeast of all workings of the Rico Argentine mine, though crosscuts on the Argentine and Blaine levels may approach it. The dike along the fault at the surface does not extend to the one underground exposure.

Throw on the Hidden fault amounts to about 400 feet, down on the northeast, where the fault displaces the top of the Hermosa Formation in the block south of the Honduras fault. Whether appreciable displacement persists along the porphyry dike north of the Honduras fault is not known.

\section{FAULTS OF DOLORES MOUNTAIN AND VICINITY}

Many faults of small to moderate throw are present in the Dolores Mountain block (pl. 1). Those at the northeast end of the block may be considered to be in the footwall of the Blackhawk fault, and an especially dominant one, about 0.35 mile from that fault, is virtually parallel to it, though its displacement is in the opposite direction. Some intervening porphyry dikes, whose fractures show only small or no displacement of the enclosing strata, are also parallel to the Blackhawk fault. Other faults in the block show no consistent trend pattern, except that nearly all strike in the quadrant between north and west and only a few strike in the northeast quadrant, from north to N. $20^{\circ}$ E. There is no consistency in the direction of displacement. Some are steep reverse faults. Numerous faults have been recognized in the middle slopes of the mountain because they cross traceable stratigraphic horizons in the middle Hermosa. Similar but unrecognized faults probably exist in the higher slopes where stratigraphic controls as well as exposures are less favorable. The block, in general, maintains a structurally high position.

Two of the faults, including the dominant one mentioned in the footwall of the Blackhawk fault, are of interest because of their large displacement and relation to the thick sill at the top of Dolores Mountain. These faults, at the head of a south prong of Allyn Gulch, bound the two sides of a wedge, pointing northwest, that has been dropped several hundred feet. The thick sill that caps Dolores Mountain has been displaced and is thus earlier than this particular faulting.

Although most of the mappable faults strike in the northwest quadrant, the ore veins of the New- 
man Hill mines are on small faults of only a few feet displacement that strike northeast and dip steeply in either direction. These are commonly broken and slightly offset by small faults of the northwest system. One of these faults of somewhat larger throw, 150 feet or more down on the northeast, projects just northeast of the Laura shaft (pl. 1 ), and may in some way account for the impoverishment of the Newman Hill ore deposits farther northeast (Ransome, 1901, p. 262).

Plate 1 shows the faults that have been recognized in surface mapping. As they are not in ground of current or predictably potential economic interest, they will not be discussed in detail.

\section{FAULTS OF DEADWOOD GULCH}

The slopes above Deadwood Gulch are cut by faults of the same general type and trend as in the adjacent Dolores Mountain block. Several in a group, trending N. $5^{\circ}-30^{\circ} \mathrm{W}$., except one trending N. $60^{\circ}$ W., cross the gulch between 700 and 1,500 feet upstream from the head of the alluvial fan at the mouth of the gulch. These faults are discernible, though poorly, on the south slope of the gulch but are concealed on the north slope under the wash and talus of Newman Hill. The westernmost three faults are down less than 100 feet on the northeast, whereas the remaining two are up on the northeast, the easternmost showing a displacement of about 250 feet. This eastern bounding fault is the only one of the group recognized by Cross and Spencer $(1900$, p. $114-15$, pl. 22). They indicate a more westerly trend, N. $65^{\circ}$ W., which is the approximate trend of one of the group at the creek crossing. Their interpretation places the major fault just southwest of the prominent outcropping ledge of middle Hermosa on the south side of Deadwood Gulch. However, projection of the faults at the gulch crossing suggests that the major fault intersects the middle Hermosa strata in the concealed slope somewhat west of the outcropping ledge, and plate 1 shows this interpretation.

\section{RELATION OF STRUCTURE TO INTRUSIVE ROCKS}

Instances in which latite porphyry sills or dikes are broken and offset by faults are innumerable, and there can be little question that much of the faulting is later than the porphyry. On the other hand, many dikes along fault zones are later than the faulting; or, if they show breakage, the evidence can be interpreted to mean that only a residuary movement, in the general nature of late settling, has taken place along the line of the fault. Thus, the Blackhawk fault is closely followed by a por- phyry dike along the entry adit on the Log Cabin (Blackhawk) level and also at several places on the Argentine and Blaine levels (pl. $3 A, B, C$ ). Certainly, there has been some movement and development of gouge in the igneous rock along the fault zone, but the very prevalence of the porphyry near the fault, whether discordant or accordant with adjacent bedding, argues for a preporphyry break along which it is reasonable to expect considerable faulting. The Honduras fault is similarly followed over part of its extent by a porphyry dike.

Possibly, most of the faulting was contemporaneous with intrusion of the monzonite stock, which was in all probability later than intrusion of the porphyry sills and dikes. Upward pressure from monzonite magma in depth may have contributed most of the doming and faulting, including the upthrusting of the Precambrian horst blocks on the eastward extension of the monzonite stock. Contactmetamorphic minerals along the general locus of the Blackhawk fault in the Rico Argentine workings up Silver Creek are on the extension of the stock elongation, and attest to the presence of an underlying igneous source of heat well after formation of this fault.

The alaskite porphyry dike a quarter of a mile east of the Argentine shaft is on the Alaskite fault of considerable throw. Most of the faulting had been completed by the time of the dike's emplacement, but even here there was a little shearing parallel to the walls after the porphyry had solidified. This shearing failed, however, to incorporate any of the porphyry into the fault breccia composed of the adjacent sedimentary rocks. The alaskite porphyry dike along the Blackhawk fault in the crosscut from the St. Louis tunnel to the Rico Argentine workings is presumably contemporaneous with the alaskite dike on the Alaskite fault.

\section{PEBBLE DIKES}

Pebble dikes and pipes have been recognized on the southeast slope of Telescope Mountain near its top; also, inside the workings of the Aztec upper tunnel and in the adjacent Edwards tunnel.

One of the dikes on Telescope Mountain is on a near-vertical fracture about 4 feet wide whose opposite walls show a vertical displacement of 5-8 feet. The dike traverses two porphyry sills and Cutler strata between them and extends from above the upper sill to at least 10 feet below the base of the lower sill. In Cutler strata 250 feet below this lower sill is another pebble dike 1 foot wide which fills an irregular steep fracture of somewhat different trend. The walls of this fracture show a 
vertical displacement of 5 feet. The pebbles and boulders in these dikes are rounded, as much as 4 inches in diameter, and comprise quartzite, siltstone, and porphyry of the same general type as that composing the sills, all in a sandy matrix. The material in the upper dike shows some shearing at the center, and in the segment above the upper porphyry the dike grades locally to a quartz vein containing clear drusy quartz.

The pebble dike that crosses the Edwards tunnel 60 feet from its portal is $1-11 \frac{1}{2}$ feet thick and nearly vertical, though irregular in detail. The boulders are mostly rounded and include latite porphyry boulders as much as 10 inches in longest diameter, alaskite porphyry boulders as much as 12 inches, and quartzite and black shale boulders as much as 4 inches. The alaskite porphyry is of the same type as that forming an irregular sill a short distance above the pebble dike exposure.

What appears to be a pebble pipe is exposed on the upper level of the Aztec mine 180 feet from the portal, in the hanging wall 20 feet from the vein. The pipe as exposed is about 1 foot in diameter and crosscuts irregularly through a black shale for an exposed length of 5 feet in the drift wall. Possibly, it is the irregular edge of a dike that is barely cut by the drift, for another pebble breccia is exposed at the end of a crosscut, 70 feet portalwards. The filling includes both angular and rounded pebbles of quartzite, siltstone, shale, and porphyry as much as 2 inches in diameter, in a matrix of finely comminuted fragmental material that is partly quartz but also includes material that is apparently pulverized and altered porphyry.

The rounded quartzite cobbles in these pebble dikes and pipes are of a type that is common in the Pennsylvanian and Permian conglomerates and presumably in some places could have fallen into the openings from adjacent sedimentary strata, but no coarse conglomerates have been found in the lower Hermosa comparable in pebble size to the quartzite cobbles found in the dikes and pipes of the Edwards and Aztec workings. Because of poor exposures, however, this fact is only of suggestive significance. The boulders and cobbles of latite and alaskite porphyries, on the other hand, could not have been derived from preexisting conglomerates and hence must have been rounded by some process other than abrasion during an erosion cycle. The suggestion is here offered that the rounding was an igneous phenomenon related to the violent escape of steam and gases through fractures in a late cooling stage of the igneous activity. Rock broken from the walls, including igneous types already solidified and pos- sibly quartzite from the Precambrian, was blown up the fractures or settled back, depending on the violence of the gaseous surge, until some of it became well rounded by abrasion. The sand composed partly of porphyry fragments in the Aztec pipes could well represent the finer material resulting from such abrasion.

\section{ORE DEPOSITS}

The ore deposits of the Rico district consist of (1) massive sulfide replacement deposits in the limestones of the Hermosa Formation; (2) contactmetamorphic deposits of sulfides, specularite, and magnetite in limestones, chiefly of the Ouray and Leadville Limestones but also of the Hermosa Formation; (3) veins on fractures and small faults in Hermosa sandstones and arkoses; and (4) replacement deposits in residual debris resulting from solution of a gypsum bed where broken by fissures in the lower Hermosa Formation. Of these types, (1) and (2) have been most productive of base metals with byproduct silver in the present century, and (1) has also yielded the pyrite for a large output of sulfuric acid; (3) and (4) were very productive of silver before 1900 .

The common sulfide minerals, present in all types of deposits, are pyrite, sphalerite, galena, and chalcopyrite. A mineral of the tetrahedrite-tennantite isomorphous series is widely distributed, probably accounting for most of the silver that is currently recovered from the ores, but it is in such small blebs that it is generally overlooked. Rarer sulfides, confined generally to certain types of deposits, include pyrrhotite, cosalite, tetradymite, and alabandite. Although no longer of significance as ore minerals, several silver minerals, mainly hypogene in their occurrence, accounted for much of the value in the lodes mined in Newman Hill before 1900, and probably some were present in early oxidized ores mined elsewhere in the district. These minerals include argentite, proustite, pearceite, polybasite, and perhaps stephanite and argyrodite. Native gold is a minor byproduct, generally too fine grained to be recognized in the ores, but locally it has contributed materially to the value of the ore, particularly in some of the rich silver ore formerly mined from Newman Hill.

The common gangue minerals are quartz, fluorite, calcite, dolomite, manganoan siderite, rhodochrosite, rhodonite, and sericite. Barite is of local occurrence. Rare gangue minerals include sellaite, huebnerite, adularia, and helvite. In the contact-metamorphic ores, specularite, magnetite, and chlorite are major 
gangue minerals. Many other high-temperature silicates are present that are of only incidental assocition with the ores.

Characteristic of the Rico deposits is the pervasiveness of manganese in the ore bodies. Although little was precipitated as the sulfide alabandite, much more appears in the gangue minerals, particularly the carbonates. In addition to minerals in which manganese is an essential constituent, such minerals as calcite, dolomite, and siderite are conspicuously manganiferous, and even some of the epidote in higher temperature associations is colored by manganese. This element must have been unusually abundant in the hydrothermal solutions given off from the magmatic source.

Some oxidized ores of lead containing high values in silver were worked in the early history of the Rico district, but at present they are of minor impact in the district economy.

Although practically all the mined ores have been confined to the Hermosa and lower formations, in places the overlying Rico and Cutler Formations have been invaded by hydrothermal solutions. Scattered thin veins containing the common sulfide and gangue minerals or their alteration products may be present. In ground that has been pervaded by hydrothermal solutions, any red beds originally present in the sedimentary sequence have generally been bleached to gray, greenish, and olive drab. The Rico and Cutler strata overlying the mineralized ground in CHC Hill are largely concealed by slide material, but the Cutler strata in places east of Strawberry Spring and in the vicinity of the prospect tunnel at an altitude of 10,788 southeast of this spring have been so altered in color that they resemble and have been mistaken for upper Hermosa strata (Cross and Spencer, 1900, pl. 22).

\section{MINERALOGY}

The mineralogy of the ore deposits differs somewhat according to the type of deposit, but the differences are not sharply defined. Some minerals are formed under a wide range of physical and chemical conditions and are present, though in varying proportions, in all types of deposits. Others, such as the iron oxides, are largely confined to a certain type of deposit. In the following discussion the hypogene minerals will be grouped as iron oxides, sulfides, native gold, gangue minerals, and metamorphic minerals of, at best, only fortuitous association with ores.

\author{
HYPOGENE MINERALS \\ IRON OXIDES \\ HEMATITE
}

The specularite form of hematite is an abundant mineral accompanying the ore sulfides in the contactmetamorphic ores, as exemplified by the Atlantic Cable and Shamrock deposits. It is also of local occurrence through the igneous metamorphic zone as far east as some of the levels of the Rico Argentine mine and in the hanging wall of the Blackhawk fault on the slopes above. It commonly forms scales imbedded in other materials.

\section{MAGNETITE}

Magnetite is most abundant in some of the opencut prospects near the monzonite contact on the west side of the Dolores River at Rico where it is associated with pyrite, quartz, some albite, and a little chalcopyrite. These deposits have not proven productive. Scattered occurrences of magnetite are present in other prospects and outcrops along the west side of the river. Magnetite is also present with specularite in the contact-metamorphic sulfide ores at the Atlantic Cable mine and more abundantly in the iron oxide shell that encases these ores. Small amounts are scattered through the igneous metamorphic zone as far east as the different levels of the Rico Argentine mine but are not conspicuous.

$$
\begin{aligned}
& \text { SULFIDES } \\
& \text { PYRITE }
\end{aligned}
$$

Pyrite is ubiquitous in the Rico district, occurring not only in all types of ore deposits, but as a widespread dissemination in the country rocks of all types, far removed from the ores.

In the mineralized ground of $\mathrm{CHC}$ Hill and the Rico Argentine mine up Silver Creek, pyrite forms extensive replacement deposits in the Hermosa limestones. The limestone beds were completely replaced, locally by compact dense-textured pyrite, but, more commonly by granular pyrite in which there was a tendency to develop crystal forms, generally the pyritohedron or combinations of pyritohedron and cube, less commonly, the cube. Where the cube is dominant, there may be sparse truncation by small octahedral faces. Crystals are generally less than half an inch in diameter, but may reach a maximum of 6 inches. These deposits grade locally to massive base-metal sulfide deposits, but, in general, pyrite remains a major constituent of the ore.

Pyrite is also an abundant constituent of the veins, some of which have contained enough other minerals of value to be profitably worked. It is also very common in the contact-metamorphic ores. 
Octahedral pyrite is rare, except as minor modifying faces on cubic pyrite. At one place on the west bank of the Dolores River just north of the porphyry dike that crosses upstream from the Shamrock mine, rather poorly formed octahedrons, slightly modified by the cube and as much as 2 inches across, replace a lower Hermosa siltstone in a contact-metamorphic association that includes specularite, magnetite, epidote, and quartz. The Pigeon, Mountain Spring, and Wellington mines contain a little octahedral pyrite in crystals as much as 1 inch across, chiefly in mineralized ground near the Blackhawk fault. Most occurrences are within 100 feet of the fault, though some are at the outer edge of pyritic blankets perhaps 200 feet from the fault, and one occurrence on the Wellington level is on the small mineralizing fault located somewhat more than 900 feet northeast of the Blackhawk fault. Some of these crystals are modified by the cube, pyritohedron, and dodecahedron. In the Blaine tunnel of the Rico Argentine mine, at the end of the 112 drift, $1 / 8$-inch crystals of pyrite in a crevice show about equal development of octahedron and cube. Some of the occurrences suggest that the octahedron is a relatively high temperature phase.

\section{PYRRHOTITE}

The only occurrence of pyrrhotite noted is in the Con crosscut of the Blaine tunnel where a little of this mineral is intimately intergrown with pyrite, magnetite, chlorite, and finely crystalline blebs of quartz along the upper contact of a thin porphyry sill in limestone. The former presence of pyrrhotite bordering porphyry dikes may also be inferred from certain textures and mineral associations resulting from the replacement of pyrrhotite by pyrite (see p. 72).

Possibly some pyrrhotite may be present along the contact of the monzonite stock with the sedimentary rocks or in the pyrite of contact-metamorphic ores at the Shamrock and Atlantic Cable mines, but if so, it has not been recognized. None of this material is now accessible.

SPHALERITE

After pyrite, sphalerite is the next most abundant sulfide in the Rico district. It is in massive intergrowths with other minerals and averages rather coarse grained, though locally, replacement material may be fine grained. Crystals of sphalerite may be present in vugs, but these are not common. A darkbrown or rosin color is most common, but it is commonly mottled with patches that may be nearly colorless or nearly black. There is no recognized cor- relation between the type or color of sphalerite and the different types of deposits. In polished section, sphalerite commonly contains anhedral to euhedral grains of pyrite and small linear or irregularly vermiform and discontinuous inclusions of galena or chalcopyrite, or both, varying in thickness and suggesting lenticular veinlets. It also contains minute anhedral or linear blebs of chalcopyrite that are commonly either parallel or are arranged in parallel lines, suggesting exsolution from the sphalerite (Edwards, 1954, p. 98-102). In some samples, the exsolved grains have a square or rectangular shape suggesting pyrite, but electron-probe analysis for the constituent elements, made by E. J. Dwornik, of the U.S. Geological Survey, shows that these also are chalcopyrite grains.

GaLena

Galena is a common mineral, occurring in massive intergrowths with other ore and gangue minerals in the several types of deposits. It averages rather coarsely crystalline, but locally replacement material may be fine grained or "steel galena." In polished section, the galena may contain small rounded grains of pyrite or irregular inclusions of sphalerite or chalcopyrite.

CHALCOPYRITE

Chalcopyrite is a widely distributed mineral in the Rico district, but in only a few pyritic bodies does it become concentrated enough to form copper ore. Green copper stains in massive pyrite that has been exposed to oxidation for a few years give a generally false impression of copper abundance. Some chalcopyrite occurs in the zinc-lead ores and the copper is generally recoverable, though the economics of milling may at times make this impractical for minor concentrations. In polished section, chalcopyrite is commonly in the sphalerite or galena as small blebs.

\section{TETRAHEDRITE-TENNANTITE}

Tetrahedrite, or its arsenic-bearing isomorph tennantite, is probably a widely distributed mineral in the Rico district, but generally occurs in such small blebs that it is rarely detected in polished sections of the ores. Presumably, much of the silver currently recovered from the district is in a mineral of this isomorphous series. Minute rounded, oval, or less regular blebs a few hundredths of a millimeter in diameter have been recognized in sphalerite, in galena, in chalcopyrite, or along contacts between these minerals. Some blebs in sphalerite are dominantly the mineral in the tetrahedrite- 
tennantite series, but include also, along their edges, subblebs of chalcopyrite. In such fine blebs, distinction between tetrahedrite and tennantite cannot be made by ordinary polished-section techniques. Both minerals, however, have been confirmed in polished sections by electron-probe analyses for the constituent elements made by E. J. Dwornik, and both carry appreciable silver, as follows :

\begin{tabular}{|c|c|c|c|c|c|c|}
\hline $\begin{array}{c}\text { Sam- } \\
\text { ple }\end{array}$ & $\begin{array}{c}\text { Host } \\
\text { mineral }\end{array}$ & $\begin{array}{l}\text { Maxi- } \\
\text { mum } \\
\text { diameter } \\
\text { of grain } \\
(\mathrm{mm})\end{array}$ & $\begin{array}{c}\text { Sb-As } \\
\text { relations }\end{array}$ & $\begin{array}{l}\text { Mineral } \\
\text { designa- } \\
\text { tion }\end{array}$ & (percent) & $\frac{\mathrm{Ag}}{\text { cent) }}$ \\
\hline $1--$ & Sphalerite_ & 0.034 & $\mathrm{Sb}>\mathrm{As}$ & Tetra- & 0.5 & 50 \\
\hline $2--$ & ---do _-_- & .043 & $\mathrm{Sb} \cong \mathrm{As}$ & $\begin{array}{l}\text { Tetrahedrite- } \\
\text { tennan- } \\
\text { tite. }\end{array}$ & .5 & 2.5 \\
\hline $3--$ & $-1-1-\cdots$ & 5.0 & $\mathrm{Sb} \cong \mathrm{As}$ & --do - do & $<.1$ & .8 \\
\hline $4--$ & Galena --- & .038 & $\mathrm{As}>\mathrm{Sb}$ & $\begin{array}{l}\text { Tennan- } \\
\text { tite. }\end{array}$ & .0 & 2.8 \\
\hline
\end{tabular}

1. Galena and spahalerite, in a specimen from dump of the Syndicate tunnel on Newman Hill.

chalcopyrite, from vein, Forest Payroll blebs include on their borders subblebs of chalcopyrite.

lacement ore from Gray tetrahedrite-tennantite, in limestone remine.

4. Sphalerite, galena, and pyrite in specimen from dump of Laura mine, on Newman Hill.

Sample 3 contained the tetrahedrite mineral in large enough patches to be the host for inclusions of sphalerite, galena, and chalcopyrite. The results of a semiquantitive electron-probe analysis of the clear mineral, made by Dwornik, are given in table 4. Although the antimony predominates over arsenic in the weight percent, the atomic ratios are more nearly balanced, giving a tetrahedrite-tennantite ratio of $53: 47$.

TABLE 4.-Electron-probe analysis of tetrahedrite-tennantite from Gray Copper stope, Yellow Jacket mine [ $\mathrm{Bi}$ was detected in the $<0.1$ percent range]

\begin{tabular}{|c|c|c|c|c|}
\hline Element & Percent & & Element & Percent \\
\hline $\mathrm{Cu}$ & 39.1 & $\mathrm{Sb}$ & - & ${ }^{1} 15.5$ \\
\hline $\mathrm{Zn}$ & 5.0 & As & 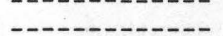 & ${ }^{2} 8.4$ \\
\hline $\mathrm{Fe}$ & 1.0 & S. & - & 28.1 \\
\hline Ag & .8 & & Total & 97.9 \\
\hline
\end{tabular}

${ }^{1}$ Average of 6 determinations, range 14.3-16.3.

The minute blebs of tetrahedrite-tennantite in sphalerite can well account for the silver that appears in the zinc concentrates marketed from the district. Such blebs were recognized in polished sections of replacement sphalerite from the 300 level of the Rico Argentine mine.

Occasionally, larger irregular grains or patches of tetrahedrite can be recognized under ordinary $10 \times$ hand lens in certain ores, such as those from the dumps of the Iron and Syndicate tunnels, from the Gray Copper stopes of the Yellow Jacket mine, and from the Sambo claim on the west side of the Dolores River south of Horse Creek. Irregular masses associated with other sulfide minerals replacing dolomite at the Sambo claim may be as much as a centimeter long; microchemical tests indicate that these masses are tetrahedrite.

Bastin (1922) showed that argentiferous tennantite was a common primary mineral in the specimens that he studied from Newman Hill.

$$
\text { POLYBASITE }
$$

Polybasite is one of the silver minerals that contributed to the richness of the blanket and lode ores mined in the early days in Newman Hill. In ground that has been accessible during our fieldwork in the district, polybasite has been found in base-metal sulfide veins at the Revenue and Iron Clad mines. In the Revenue vein, it occurs in characteristic small crystals resembling hexagonal dises, $0.5 \mathrm{~mm}$ in diameter, molded against late quartz in the vuggy center of the vein. In the No. 1 tunnel of the Iron Clad, it occurs in similar crystals associated with pyrargyrite and argyrodite in thin calcite veinlets within the thicker sulfide vein. The identification was confirmed by Mary Mrose and Ralph P. Christian, of the U.S. Geological Survey, from the X-ray photograph of the powder pattern and from a qualitative X-ray fluorescence scan for constituent elements, respectively. The fluorescence scan indicated major antimony and only very minor arsenic; it also showed considerable copper substituting for the dominant silver.

$$
\text { PYRARGYRITE (RUBY SILVER) }
$$

Although Farish (1892, p. 161) mentioned pyrargyrite as a constituent of the Newman Hill ores, this mineral was not found by Ransome (1901), nor was it mentioned by Rickard (1897). It occurs in at least one of the veins of the Iron Clad No. 1 tunnel, in close association with polybasite and argyrodite. The pyrargyrite is in crystalline grains a quarter of an inch in longest dimension; these grains, with associated calcite and polybasite, completely fill a late $1 / 8$-inch crack in the pyritic vein. Identification of the pyrargyrite was confirmed by Mary Mrose from the powder pattern revealed in the X-ray photograph. A qualitative X-ray fluorescence scan, made by Ralph P. Christian, indicated antimony as a major constituent and no arsenic.

$$
\text { ARGYRODITE }
$$

The silver-germanium sulfide, argyrodite, occurs with polybasite and pyrargyrite in thin calcite stringers within a thicker sulfide vein in the Iron 
Clad No. 1 tunnel. Irregular grains of the mineral are generally 2 or $3 \mathrm{~mm}$ across. This mineral also forms small blebs of comparable size, with or without associated calcite, within the massive pyrite of the vein, or it may be intergrown with the pyrite. The mineral was identified by Mary Mrose from the X-ray photograph of the powder pattern, and the silver and germanium were confirmed as major constituent elements from an X-ray fluorescence scan made by Ralph P. Christian.

ARGENTITE, PROUSTITE, PEARCEITE, AND PERHAPS STEPHANITE (?)

Although none of the silver minerals argentite, proustite, pearceite, or stephanite have been seen in the deposits examined by the author, they are here mentioned because of their importance in the past history of the Rico mining district. Farish (1892, p. 161), Ransome (1901, p. 251), and Bastin (1922, p. 110-116) discussed their occurrence in the rich blanket and lode ores of Newman Hill, which owed their richness mainly to these minerals, plus polybasite. The mines of that area have long been abandoned and caved. Sporadic specimens of these minerals may turn up in unexpected places or in private mineral collections, but their importance in the district has faded.

\section{COSALITE}

Cosalite $\left(\mathrm{Pb}_{2} \mathrm{Bi}_{2} \mathrm{~S}_{5}\right)$ was found at three localities: at the entrance of the A 180 drift in the Argentine tunnel; near the 100 raise in the Blaine tunnel; and in the " 4 bed" stope between the Argentine and Blaine tunnels. The first and third localities are nearly 1,100 feet apart. The mineral is inconspicuous and easily confused with galena; hence, it may be commoner than indicated. Occurrence is similar at the three localities-namely, as small silver-gray metallic blebs crudely banded in fluorite or disseminated in sericite that, in turn, are interstitial to the pyrite of massive replacement deposits in limestone. Polished sections show that the cosalite blebs are composed of several anhedral crystal grains. The mineral is in part molded against the cubic crystals of pyrite but is also in places intergrown anhedrally with, or forms inclusions in, the pyrite. It may also be finely intergrown with chalcopyrite. In the "4 bed" stope, grains of huebnerite are also present in the fluorite.

The constituent elements of the cosalite were identified microchemically and also by an X-ray fluorescence analysis made by Robena Brown of the U.S. Geological Survey. The qualitative composition does not distinguish between several minerals, but the X-ray powder pattern and atomic spacing data determined therefrom by Mary E. Mrose, show that the mineral is cosalite.

TETRADY MITE

Tetradymite $\left(\mathrm{Bi}_{2} \mathrm{Te}_{2} \mathrm{~S}\right)$ occurs, without other accompanying sulfides, in several quartz veins and veinlets in the northwest crosscut, $900-1,000$ feet northwest from the St. Louis tunnel. The locality is in the hanging wall of the Blackhawk fault, within 150 feet of the fault. The mineral is in micaceous silvery gray folia $1 / 8-1 / 4$ inch across, showing perfect, but somewhat deformed, cleavage faces and resembling molybdenite. The identity was established by Mary E. Mrose from a photograph of the $\mathrm{X}$-ray powder pattern, and the chemical composition was confirmed qualitatively by an X-ray fluorescence analysis made by Ralph P. Christian.

ALABANDIT E

The monosulfide of manganese, alabandite, is a rare mineral in the district, having been recognized from only two localities-the Mountain Spring mine (A level), and deep within the Blaine tunnel of the Rico Argentine mine (just east of the lower end of the 138 stope). It occurs as blebs, a quarter of an inch or less across, in manganiferous calcite (Mountain Spring mine) or rhodonite (Blaine tunnel). These gangue minerals accompany massive sulfides that replace limestone beds.

\section{NATIVE GOLD}

Gold is a minor constituent of nearly all the sulfide concentrates marketed from the district, averaging, for example, 0.015 ounce per ton in the lead concentrates of the Rico Argentine Mining Co. Although the mode of its occurrence is not generally known, it is presumed to occur as free metal. Silver ores mined in the early days from Newman Hill are reported to have contained $0.3-0.5$ ounces gold per ton.

There is one known occurrence of megascopic free gold. At the Jones gold mine, the most spectacular gold occurs in boxworks as much as $11 \frac{1}{2}$ inches across, made up of scales and wires. Some of the scales are flattened flakes half an inch in diameter. Some of the boxworks are in druses containing broken prismatic quartz crystals; this suggests that some substance has been leached out to form the druses. This substance may have been calcite, for in some of the ore from the mine, the gold is in calcite but so fine grained as to be invisible. The Jones gold mine has not been a rich producer, owing to the sporadic and unpredictable occurrence of the richer pockets of gold. 


\section{GANGUE MINERALS QUARTZ}

The most abundant of the gangue minerals is quartz. It is common in the fault veins, but its prominence varies with different veins. The Blackhawk fault is particularly quartz rich, whereas others, such as the Princeton fault, contain little quartz and that only locally. The quartz is white to colorless and generally massive, as it commonly replaces the fault gouge. Locally, however, it may develop columnar crystals in vugs that may show amethyst colors. Quartz is also present, but less common, in small pockets, partly associated with other gangue minerals, in the massive replacement sulfides. In places, the quartz grains are euhedral in massive pyrite.

\section{JASPEROID}

Silicification of limestone to jasperoid as a phase of the ore mineralization is rare at Rico, but it has occurred locally, as at a few places adjacent to the Blackhawk fault in the Rico Argentine mine. Here, the jasperoid is a microscopic mosaic of quartz in which the elongation of the grains parallel to the $c$ axis is in places as pronounced as in typical Mississippi Valley ores. The jasperoid here and elsewhere contains finely disseminated sericite and pyrite, and much of it contains, in addition, disseminated fluorite which is also concentrated along certain thin fractures.

\section{CALCITE}

Calcite is a very common and widely distributed gangue mineral, occurring in the replacement deposits including those of the contact-metamorphic type and also in the veins, though not present in all veins. It is a common mineral accompanying the gouge in faults. Locally, it may crystallize in vugs as small scalenohedral crystals.

A notable characteristic is the presence of manganese in nearly all samples of calcite that have been tested. A little ferrous iron is also present in some but is less common. Variation in the composition of the calcite is reflected in the indices of refraction. Thus, the high index $(n \mathrm{O})$ ranges from 1.66 to 1.71 , though in most samples it is 1.68 or less. A finegrained calcite that is intergrown with fibrous diopside-hedenbergite replacing limestone at several places in the mines generally contains appreciable manganese and iron, and $n \mathrm{O}$ correspondingly ranges from an undetermined lower value to as much as 1.695. The calcite associated with garnet, on the other hand, is low in manganese.

Table 5 gives the chemical analyses of five calcite
TABLE 5.-Chemical analyses, semiquantitative spectrographic analyses, and indices of refraction of calcite from the Rico disrict, Colorado

\begin{tabular}{|c|c|c|c|c|c|}
\hline & 1 & 2 & 3 & 4 & 5 \\
\hline \multicolumn{6}{|c|}{ Chemical analyses } \\
\hline $\begin{array}{l}\mathrm{CaO}=- \\
\mathrm{MgO}=- \\
\mathrm{FeO}=-- \\
\mathrm{MnO}=- \\
\mathrm{CO}_{2}=-\end{array}$ & $\begin{array}{c}56.33 \\
.0 \\
.32 \\
.40 \\
42.94\end{array}$ & $\begin{array}{r}52.94 \\
.16 \\
.40 \\
3.70 \\
42.80\end{array}$ & $\begin{array}{r}52.17 \\
.51 \\
.27 \\
5.64 \\
41.42\end{array}$ & $\begin{array}{r}50.30 \\
.30 \\
.32 \\
6.55 \\
42.51\end{array}$ & $\begin{array}{r}37.99 \\
.55 \\
.48 \\
19.35 \\
41.62\end{array}$ \\
\hline Total & 99.99 & 100.00 & 100.01 & 99.98 & 99.99 \\
\hline \multicolumn{6}{|c|}{ Semiquantitative spectrographic analyses } \\
\hline $\begin{array}{ll}\mathrm{Ag} & -\cdots \\
\mathrm{Ba} & --- \\
\mathrm{Sr} & ---- \\
\mathrm{Y} & -\cdots- \\
\mathrm{V} & -\cdots\end{array}$ & $\begin{array}{l}0.0 \\
.0 \\
.02 \\
.0 \\
.0015\end{array}$ & $\begin{array}{l}0.0003 \\
.0 \\
.01 \\
.003 \\
.002\end{array}$ & $\begin{array}{l}0.0003 \\
.0 \\
.05 \\
.0 \\
.002\end{array}$ & $\begin{array}{l}0.0003 \\
.0 \\
.03 \\
.0 \\
.002\end{array}$ & $\begin{array}{l}0.0 \\
.0005 \\
.02 \\
.0 \\
.005\end{array}$ \\
\hline \multicolumn{6}{|c|}{ Indices of refraction } \\
\hline$n \mathrm{O}_{-.--}$ & 1.66 & 1.67 & 1.668 & 1.675 & 1.71 \\
\hline
\end{tabular}

1. Rico Argentine mine, Blaine level, end of short drift at coordinates $14,167 \mathrm{~N}, 14,674 \mathrm{E}$ (pl. $3 \mathrm{C}$ ); coarsely crystalline calcite, clear, light pink, but low manganese: ocurs in pockets in massive garnet rock replacing limestone at border of porphyry dike.

2. Rico Argentine mine, Blaine level, stope at 13,590N, 15,662 E (pl. 3 C); small crystalls of drusy scalenohedral calcite with flat rhombohedral terminations (0112); clear, light brownish yellow.

3. Dump of prospect tunnel, west bank of Dolores River $1 / 2$ mile south of Rico, $800 \mathrm{ft}$ south of Rico Boy tunnel; sulfide vein material on dump includes coarsely crystalline white opaque calcite.

4. Jones gold mine (St. Louis tunnel; not related to St. Louis tunnel of St. Louis Smelting \& Refining Co.), just above Engel's mine road on west side of river at Rico; crystalline manganocalcite showing curved cleavage faces, white, but some showing slight pinkish

5. Replace from gold ore pocket in unsurveyed stope above haulage level. slope, in Cutler Formation, $1,300 \mathrm{ft}$ east-southeast of Strawberry slope, in Cutler Formation, 1,300 ft east-southeast of Strawberry opaque white with very pale pinkish tinge.

samples from the district, recalculated to 100 percent after subtracting the residue of associated materials that were insoluble in dilute acid. The analyses were made by Angelina Vlisidis, of the U.S. Geological Survey. Semiquantitative spectrographic analyses for several additional elements are included. All are quoted in percent. Approximate indices of refraction as determined in white light are appended.

The spectrographic analyses indicate appreciable contents of vanadium that are roughly proportional to the manganese content.

\section{DOLOMITE AND MANGANOAN DOLOMITE}

In certain areas of hydrothermal mineralization, some of the Hermosa limestones have been in part dolomitized without much change in appearance. Thus, the $\mathrm{C}$ bed in the immediate hanging wall of the Blackhawk fault on the Blaine level is largely fine-grained light-gray dolomite, as is also its lower part on the underlying 200 level. This massive rock dolomite is perhaps commoner than the known occurrences would suggest, but it so resembles the original limestone that, unless specific tests are made, it remains undetected. 
Dolomite also occurs sporadically as a minor constituent in veins and in sulfide replacement masses, including contact-metamorphic masses. It appears in vugs where it is generally later than quartz and associated sulfide minerals, but it may also occur in small replacement pockets or as interstitial filling of replacing sulfides, including granular pyrite. In some contact-metamorphic masses, it is interstitial to granular magnetite. The vug crystals are curved rhombohedrons, generally of pinhead size but in places as much as 0.2 inch across. The material in replacement pockets may be considerably coarser grained. Some of the dolomite is colorless, but most of it is white, cream colored, or light brown. Chemical tests show that it contains varying amounts of manganese and ferrous iron, extreme examples approaching manganoan ankerite in composition. The indices of refraction are accordingly variable, the high index $(n O)$ ranging from 1.685 to 1.705 . Ferrous iron and manganese are also present in the massive rock dolomite of the Blaine and 200 levels, and elsewhere, strengthening the presumption that such dolomite is of hydrothermal origin.

Dolomite is also present as a partial filling of amygdules in the lamprophyre dike above Newman Hill and as a partial constituent in small blebs of uncertain origin in the alaskite porphyry dike exposed near the portal of the Aztec mine. The latter occurrence is probably not an alteration product of the igneous rock, for analysis of the freshest rock available (not from the Aztec locality, however) shows very little $\mathrm{CaO}$ or $\mathrm{MgO}$ (table 3 ). The dolomite here is intimately mixed with slender quartz prisms as much as $0.75 \mathrm{~mm}$ long, some fine sericite, and a little fine pyrite in small segregations within the alaskite porphyry. The type of quartz suggests a hydrothermal product, and perhaps these blebs represent hydrothermal replacement of the igneous rock. The dolomite in both the lamprophyre and alaskite porphyry occurrences contains ferrous iron, and that in the alaskite contains considerable manganese.

Table 6 gives the chemical analyses of two dolomite samples from the district, analyzed in the same series with the calcite samples of the preceding section.

Sample 2, with molecular ratios of $\mathrm{Ca}: \mathrm{Mg}: \mathrm{Fe}: \mathrm{Mn}$ $=52.09: 33.58: 4.06: 10.28$, is a manganoan dolomite according to Palache and others $(1951$, p. 208$213)$, but it is a manganoan ankerite according to Deer, Howie, and Zussman (1962, v. 5, p. 295-298).

MANGANOAN SIDERITE

Siderite is not an abundant mineral but is rather widely distributed and shows several types of occur-
TABLE 6.-Chemical analyses, semiquantitative spectrographic analyses, and indices of refraction of clolomite from the Rico district, Colorado

\begin{tabular}{|c|c|c|}
\hline & 1 & 2 \\
\hline \multicolumn{3}{|c|}{ Chemical analyses } \\
\hline 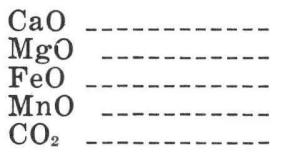 & $\begin{array}{r}31.93 \\
18.00 \\
2.26 \\
2.80 \\
45.01\end{array}$ & $\begin{array}{r}30.53 \\
14.50 \\
3.05 \\
7.62 \\
44.30\end{array}$ \\
\hline Total _.... & 100.00 & 100.00 \\
\hline
\end{tabular}

\begin{tabular}{|c|c|c|}
\hline \multicolumn{3}{|c|}{ Semiquantitative spectrographic analyses } \\
\hline $\mathrm{Ag}$ & 0.001 & 0.0005 \\
\hline $\mathrm{Ba}$ & .001 & .0005 \\
\hline $\mathrm{Sr}$ & .007 & .007 \\
\hline Y & .0 & .0 \\
\hline $\bar{V} \quad-\ldots$ & .001 & .003 \\
\hline Mo & .007 & .0 \\
\hline
\end{tabular}

\begin{tabular}{lcc}
\hline \multicolumn{3}{c}{ Indices of refraction } \\
\hline$n 0 \quad-\ldots-1.685$ & 1.705 \\
\hline
\end{tabular}

1. Rico Argentine mine, 200 level, small stope at end of crosscut into footwall of Blackhawk fault, at $14,335 \mathrm{~N}, 13,694 \mathrm{E}(\mathrm{pl}$. $3 D)$; creamy white curved rhombs of dolomite, $1 / 8$ in. across, growing on fine drusy quartz surface in vug.

2. Mountain Spring mine, southeast drift on ore vein in top of lower Hermosa, at $20,080 \mathrm{~N}, 17,780 \mathrm{E}$ ( pl. 2 C.): colorless rhombs of dolomite, $1 / 10$ in. across, associated with fine drusy quartz, kaolinite, sphalerite, and pyrite, in vug in fault vein.

rence. It is present with chlorite and specularite in the massive replacement matrix that encloses the contact-metamorphic sulfide deposits of the Shamrock mine, and locally it lines small vugs in this environment. In the Argentine and Blaine tunnels of the Rico Argentine mine, it occurs sparingly on the contact between latite porphyry sills and limestone where it is associated with pyrite, quartz, a little magnetite and chalcopyrite, locally specularite, and in at least one place, pyrrhotite. Siderite occurs in a vein near the end of the Falcon tunnel and in vein material on the dumps of the Laura, Syndicate, and Stephanite mines on Newman Hill. Bastin (1922) reports it in other vein and replacement ores from Newman Hill. In these vein occurrences it is associated with quartz, pyrite, and base-metal sulfides. At one locality on the A level of the Mountain Spring mine, siderite in vugs forms the exterior part of small crystals whose cores are manganoan dolomite (ankerite?), in abrupt contact with the siderite.

The siderite may occur as grains in a replacement matrix, as small rhombs or botryoidal clumps lining vugs, or in finely to coarsely crystalline light-brown masses in the veins, partly in the centers of quartz veins in the Newman Hill occurrences. It is everywhere strongly manganiferous and commonly carries some calcium and magnesium, as determined qualitatively by microchemical methods. The high 
index of refraction $(n \mathrm{O})$ ranges from 1.79 to 1.85 , in accordance with the variations in chemical composition. Possibly those samples in the lower part of the index range may more properly be classed as ferroan rhodochrosites, but the colors, where not concealed by oxidation products, are pale brown and more nearly those of siderite. The material is too intimately mixed with impurities, including oxidized material, to warrant analyses. The oxidized material is generally black from the contained manganese.

RHODOCHROSITE

Much of the pink gangue accompanying the ores is rhodonite, but many such occurrences, when examined microscopically, contain a little very fine carbonate flecked in the rhodonite. The high index of refraction of this carbonate is considerably higher than $n \mathrm{Z}$ of the enclosing rhodonite $(n \mathrm{Z}=1.73-1.74)$. When the mixture is powdered, part of it is readily soluble, with effervescence, in mineral acids, and the solution gives copious chemical reactions for $\mathrm{Mn}$. As rhodonite is insoluble in such acids, the Mn in solution came from the dissolved rhodochrosite.

In some places, and particularly in the mines of Newman Hill, rhodochrosite occurs in the sulfidebearing veins, in part without accompanying rhodonite. It is light pink and may form curved rhombohedral crystals as much as a tenth of an inch across in vugs. Such material from the Revenue mine (upper level) has the high index of refraction $n \mathrm{O}=1.795$; it contains considerable calcium and some iron when tested qualitatively. Another sample, from replacement ore bordering a porphyry dike on the Argentine level of the Rico Argentine mine, has the same index of refraction but is very pale pink, and contains much iron and considerable calcium. There is evidently complete gradation to siderite in the district.

$$
\text { RHODONITE }
$$

Rhodonite is widely distributed in sulfide-bearing veins and in country rock bordering sulfide replacement ore. Less commonly, it occurs in small pockets in replacement sulfide ore. It is locally common, as in the veins of Newman Hill where, with rhodochrosite, it tends to be banded along the borders of crustified veins. Probably much of it has been misidentified as rhodochrosite, but chemical and optical tests prove that much of the pink gangue is this silicate. The refractive index of the slow ray on cieavage fragments (near $n \mathrm{Z}$ ) ranges from 1.73 to 1.74 .

FLUORITE

Fluorite is a common gangue mineral in the ore deposits of CHC Hill and of the Rico Argentine mine, occurring both in pockets in the massive replacement sulfides and as part of the filling in the smaller veins. Much of it is white, but the purple phase is also present. Fluorite is particularly common in the massive pyritic bodies where it may fill pockets as much as 1 foot across. Cubic crystals $(1 / 2$ in.) are occasionally found in vugs but are not common. Fluorite also occurs in one of the alaskite porphyry dikes in the Pigeon tunnel where it forms irregular disseminations 1 or $2 \mathrm{~mm}$ across in the hydrothermally altered rock.

$$
\text { SELLAITE }
$$

The rare fluoride of magnesium, sellaite, occurs in a granular fine-grained mixture with chalcopyrite, fluorite, and sericite in an unsurveyed stope, 50 feet west of the 8 raise, Argentine tunnel. The mineral was identified by its optical properties, including indices of refraction less than 1.40 , and by qualitative microchemical confirmation of magnesium. Identification was further confirmed by an X-ray picture of the powder, made by Mary E. Mrose.

The sellaite is generally intergrown with fluorite but shows some stout prismatic crystal forms. One mount of crushed fragments in index oil showed a twin pair in which the twinned prisms, each about $0.2 \mathrm{~mm}$ long, were joined at an obtuse angle like the common twin of rutile. Manipulation of the twin against other fragments allowed a rough measurement of the angle between the twinning plane and the prismatic axis in each of the two parts of the twin. The two readings of this angle were $55^{\circ}$ and $58^{\circ}$, which are only approximations considering that the orientation had to be by inspection. If the twinning and composition plane in this twin of sellaite is 011 , as a rutile, the angle should be $56^{\circ} 351 / 2^{\prime}$, which is close to the average of the two readings made. The "System of Mineralogy" (Palache and others, 1951, p. 37-39) does not record this twin for sellaite, though it is described and (incorrectly) figured by Heidorn (1932).

$$
\text { SERICITE (PHLOGOPITE AND MUSCOVITE) }
$$

Sericite is an abundant interstitial mineral of the massive sulfide replacement deposits, particularly the pyrite masses. Here, it forms a greenish-gray talclike matrix in which the pyrite grains are embedded, its abundance varying reciprocally with the intensity of the pyritization. Some of the talclike material replacing limestone has practically no accompanying pyrite. Where the pyrite has replaced sandstone or arkose, the sericite may occur with the pyrite and fluorite in fine veinlets in the replaced rock. 
X-ray diffraction pictures of the talclike matrix, made by Mary E. Mrose, shows that in some places this matrix is phlogopite, in others it is muscovite, and in still others it is a mixture of the two. In the small fraction of mineral grains coarse enough for optical study by petrographic microscope, the optic axial angle is generally $5^{\circ}-15^{\circ}$, even in samples whose powders reveal only a muscovite pattern in $\mathrm{X}$-ray pictures. This suggests that the coarser grains are phlogopite, even though it may not be abundant enough to be indicated in the X-ray pictures.

Sericite is also a common constituent of the contact-metamorphic assemblage. Some of the material shows the low optic axial angle and slight pleochroism of phlogopite. An X-ray powder picture of contact-metamorphic material from the nose of Nigger Baby Hill shows that it is here a mixture of muscovite and illite.

As already stated, sericite is a ubiquitous alteration product in the latite porphyry and monzonite, particularly in areas of hydrothermal mineralization. In extreme examples, as in places along the Blackhawk fault in the Argentine and Blaine tunnels, the porphyry has been profoundly altered to a mass of coarse pearly white sericite containing granular pyrite, apatite, and a little crystalline quartz. Some of the sericite is in fine globules or thin drusy coatings of a brownish flesh color, lining interstitial vuglets. The globules show a radiating platy structure and pearly luster. Although cleavage flakes of some of the material show a low optic axial angle, all material that was tested by X-ray yields powderdiffraction patterns that are typical of muscovite.

$$
\text { APATITE }
$$

Fine-grained apatite crystals occur in highly sericitized porphyry, and in pore spaces or in interstitial sericite or fluorite of massive pyrite replacement deposits in limestone. The largest crystals are about $1 \mathrm{~mm}$ long. Similar crystals of apatite also occur in association with the common contact-metamorphic minerals. Some appear as idiomorphic inclusions in garnet. All crystals tested show the high index of refraction $(n \mathrm{O})$ to be about 1.63-1.64, indicating that the variety is fluorapatite.

\section{HUEBNERITE}

The " 4 bed" stope between the Argentine and Blaine levels is in a massive sulfide body that replaces a limestone bed. At one place in this stope where the replacing sulfide is cubic pyrite, redbrown grains of huebnerite $\left(\mathrm{MnWO}_{4}\right)$ showing a maximum diameter of about $1 \mathrm{~mm}$ are imbedded in fluorite that is interstitial to the pyrite. Polished sections show an occasional grain enclosed in the pyrite; conversely, some of the grains contain very small anhedral (dominantly) or euhedral inclusions of pyrite. Blebs of cosalite are closely associated with the huebnerite.

The huebnerite grains are rounded or semihedral. Thinner fragments are transparent and have the requisite optical properties, including an index of refraction that is well above the 2.008 index of the liquid in which tested. Microchemical tests indicate dominant manganese and tungsten and only a minor content of iron.

ADULARIA

The adularia form of potassium feldspar, consisting of rhombic crystals, is an uncommon gangue mineral. Crystals that are $1 \mathrm{~cm}(0.4 \mathrm{in}$.) across were found in a vug in massive pyrite on the $\mathrm{C}$ bed sublevel between the Mountain Spring and Wellington levels. On the upper level of the Aztec mine and at the Columbia prospect below, minute rhombic crystals of adularia are part of the gangue of replacement sphalerite in silicified shale immediately bordering the Nellie Bly quartz vein.

\section{KAOLINITE}

Small pockets of an opaque white dense clay mineral molded against sphalerite in replacement ore from the D level of the Mountain Spring mine are kaolinite, according to a determination made by Mary E. Mrose from X-ray of the powder. Optically similar material, enclosing minute cubes of pyrite, is found elsewhere in this mine, and in the Wellington mine above, in the limestone immediately bordering replacement or vein sulfide mineralization. A common occurrence is at the base of massive pyrite which replaces only the upper part of a limestone bed. Kaolinite also occurs sparingly in veins containing pyrite, sphalerite, and dolomite in the Mountain Spring mine, and in veins containing calcite on the Blaine level of the Rico Argentine mine. In both these vein occurrences the kaolinite is earlier than the carbonate lining the late vugs. On the whole, kaolinite must be classed among the less common gangue minerals of the district.

\section{BARITE}

Barite was found only along the Nellie Bly fault vein on the slope west of the Dolores River. Here, it forms part of the gangue in vein ore and in replacement ore adjacent to the vein at the Aztec mine and at prospects downslope from this mine. The barite forms thin white bladed crystals, commonly radiating, and as much as 1 inch across. 
Siliceous casts of platy crystals show that barite was present elsewhere in the district as an earlystage mineral but was leached out before the end of the mineralization. Particularly striking examples were found in a stope on the Blaine level, 30 feet southeast of the crosscut to the No. 3 shaft. Here, at 15 feet in the hanging wall of the Blackhawk fault, a vug in the replaced limestone contains numerous paper-thin shells of quartz molded around voids having orthorhombic proportions. The unbroken shells have the shape, and the largest have approximately the size, of half a stick of chewing gum. Cross sections show that the leached mineral was a simple plate bounded by the three pinacoidal faces having right-angle intersections. In part, the crystals are in parallel growths. The crystal form approximates that of barite crystals from Pfalz, West Germany, as illustrated by Goldschmidt (1913, text, v. 1, p. 157 ; plates, v. 1, p. 153, fig. 245). After the barite was leached out, small scalenohedral crystals of manganiferous calcite were deposited sparingly on the insides of the casts.

Casts of a thin-bladed mineral, probably also barite, occur in replacement quartz in the same general block of ground, 100 feet in the footwall of the Blackhawk fault on the 200 level of the Rico Argentine mine, southwest of the No. 3 shaft. Similar casts were found in vein quartz farther southeast along the Blackhawk fault on the Blaine level and along the Last Chance fault in the Last Chance tunnel. Rickard (1897, p. 979) reports "beautiful pseudomorphs of quartz after baryta" from the Enterprise mine in Newman Hill.

\section{ARAGONITE}

Aragonite is a rare gangue in the ore deposits, apparently as a late mineral of only accidental association. One occurrence is in small solution vuglets in a calcian and ferroan rhodochrosite which contains disseminated sulfides, chiefly pyrite, but also a little sphalerite and galena. Absence of any oxidation products suggests that the solution was during late stages of the primary mineralization. Other occurrences suggest a secondary origin.

HELVITE

Helvite, a silicate-sulfide of beryllium, manganese, and iron, is a rare mineral in the district. It was found at a single locality in the Blaine tunnel at the lower end of the 138 stope. Here, it occurs as replacement blebs in the limestone (L bed) just below the tapered wedge of massive pyrite on which the stope was developed. Closely associated replacement minerals are rhodonite, pyrite, and a little alabandite which, however, are not intermixed with the helvite.

The helvite is in soft pulverulent sulfur-yellow blebs, a quarter of an inch across, composed of microscopic rounded grains. The index of refraction is about 1.74. A photograph of the X-ray powder pattern and atomic-spacing data determined therefrom by Mary E. Mrose indicate that the mineral is a member of the helvite group (Glass and others, 1944). An X-ray fluorescence milliprobe analysis by Ralph P. Christian shows that the composition is close to that of helvite. Manganese is the dominant metallic element; iron and zinc are both present in minor amounts, iron being greater than zinc.

\section{METAMORPHIC MINERALS OF, AT BEST, ONLY FORTUITOUS} ASSOCIATION WITH ORES

Contact-metamorphic minerals related to the various igneous bodies are widely distributed in the Rico district. Some are characteristically formed in limestones bordering dikes and sills. As such places are locally the sites for later ore deposits, these metamorphic minerals may acquire a fortuitous association with ore but are not, strictly speaking, true gangue minerals. Garnet, epidote, and diopsidehedenbergite are especially prone to such association. Magnetite and specularite, showing the same associational characteristics, have already been treated. Several other metamorphic minerals show no association with ore but are briefly discussed in the following pages as part of the total mineralization picture.

GARNET

Garnet is a common and widely distributed mineral, occurring in scattered replacement pockets with other minerals of the contact zone near the monzonite stock, and also bordering, or near, porphyry dikes and sills in more remote areas. Locally it may replace the porphyry. It is generally massive or granular but shows numerous crevices and vugs where euhedral faces have formed, or these faces may abut against interstitial calcite patches or recrystallized limestone. The massive material is olive yellow, olive green, or olive brown; the euhedral material may be olive yellow but is more commonly red brown. The crystals are generally zoned and may include zones of calcite or quartz that are in optical continuity with that of the adjacent interstital patches. The index of refraction, $n$, ranges from 1.80 (zones in small olive-yellow crystals) to 1.88 (red-brown crystals and olive-brown massive material). Most of the garnet equals, or approaches, the latter index. In some garnets the index varies 
within single crystals. Thus, a crystal from metamorphosed strata in the upper Hermosa south of the Sunflower workings in Allyn Gulch shows an index of 1.88 in isotropic parts of the crystal and of 1.83 in anisotropic parts. A thin section shows that the anisotropism is in gradational zones which recur from the center of the crystal outward.

The index of refraction and cell dimension $\left(a_{0}\right.$, in angstroms) for the atomic spacing on three samples are as follows:

\begin{tabular}{cccc}
\hline Sample & $n$ & $a_{0}{ }^{1}$ & $\begin{array}{c}\text { Comments regarding } \\
\text { cell dimensions }{ }^{1}\end{array}$ \\
\hline $1---$ & 1.88 & $12.038 \pm 0.015$ & $\begin{array}{l}\text { Homogeneous. } \\
\text { Some zoning toward } \\
\text { a garnet with } \\
a_{0} \text { 12.3. } \\
\text { Relatively broad } \\
\text { range of varia- } \\
\text { tion. }\end{array}$ \\
\hline
\end{tabular}

${ }^{1}$ By D. B. Stewart, U.S. Geological Survey.

1. Blaine tunnel of Rico Argentine mine, at coordinates $14,167 \mathrm{~N}, 14,674 \mathrm{E}$ (see pl. 3C); red-brown crystal bordering a calcite pocket, from contact zone in limestone at border of thick porphyry dike.

2. Porphyry dike, west side of Dolores River nearly due west and about $850 \mathrm{ft}$ from Atlantic Cable shaft; red-brown crystal bordering vug in garnetized zone in porphyry.

3. Blaine tunnel, at coordinates $14,682 \mathrm{~N}, 14,125 \mathrm{E}$ (pl. $3 C$ ); small oliveyellow crystals, $1 / 2-1 \mathrm{~mm}$ in diameter, embedded in recrystallized limestone at top of thin porphyry sill.

The indices of refraction and cell spacing of these samples, referred to the compositional charts of Winchell (1958), show that the dominant garnet, represented by sample 1 , is a fairly pure andradite, the common garnet of contact-metamorphic deposits in limestone. The other two garnets are on, or very close to, the andradite-grossularite compositional line, the extreme (sample 3) showing the approximate composition of $\mathrm{An}_{53} \mathrm{Gr}_{47}$.

\section{DIOPSIDF-HEDENBERGITE}

Diopside-hedenbergite is found throughout the contact zone related to the monzonite stock. Close to the stock, as in parts of the Black Wonder prospect, it may appear as a fine-grained massive replacement of limestone, greenish gray, and resembling finegrained sandstone. It is also a common replacement mineral in limestones at their contacts with porphyry dikes and sills in the mines, but it may occur as much as 35 or 40 feet from porphyry bodies, or it may occur in limestones adjacent to faults, such as the 210 Drift fault, along which hot solutions are presumed to have risen. In these occurrences, it characteristically forms radiating tufts of acicular crystals, commonly 1 or 2 inches long, and greenish gray. Fine-grained pyrite, sphalerite, and galena are commonly intergrown, and microscopic examination reveals an abundance of interstitial calcite. The sulfides accompanying the diopside-hedenbergite are generally too sparse to be of economic interest, but where ore bodies have formed on the borders of igneous masses, the diopside-hedenbergite becomes a fortuitous gangue mineral. It is equally common, but generally inconspicuous, in shales and arkoses where it is finer grained and may in part occur in thin replacement veinlets. Where it occurs with garnet, it may be in thin veinlets cutting the garnet. An unusual occurrence in limy silty shale bordering a dike at the back end of the Log Cabin straight adit is a fine-grained replacement aggregate resembling novaculite, in which the individual diopside granules average less than $0.005 \mathrm{~mm}$ in diameter and can be identified only from the X-ray powder pattern.

The indices of refraction show that several members of the isomorphous series between diopside and hedenbergite are present. The highest value found for $n \mathrm{Z}$ is 1.75 , indicating hedenbergite, but this is exceptional, and most samples fall within the diopside-salite range. Some of the material when examined microscopically shows polysynthetic twinning.

EPIDOTE

Epidote is a common-contact metamorphic mineral, particularly in shales and arkoses, in the contact zone bordering the stock and at the edges of igneous dikes and sills, but it may also appear at some distance from igneous bodies. It may be coarsely crystalline, though commonly anhedral. Epidote is also a common alteration product of plagioclase and hornblende in the latite porphyry.

Some of the epidote is the pink variety, withamite, from contained manganese and is easily confused with rhodonite. Most of the observed occurrences were in the mines, but some appears in the contact zone of the monzonite stock, and some is in shear zones in the stock. A common host rock is the highly altered porphyry that is present in dikes and sills within the mines. Pink epidote is generally present as replacement blebs and thin veinlets, but locally, it forms finely crystalline coatings in small vugs. It may occur in close proximity to normal green epidote, as for example, surrounding the green in replacement blebs. Microscopic examination shows that the pink epidote is distinctly pleochroic; $X=$ colorless, $Y=$ faintly pink, $Z=$ pink. In some of the crystals the pink color is confined to the centers, and the edges are colorless for all directions of light transmission. The mineral composition is evidently very near the border between epidote and clinozoisite, for the highest index of refraction $(n Z)$ is about 1.74 , and the axial angle is near $90^{\circ}$. None of the material collected was suitable for chemical 
analysis, but probably the percentage of manganese is small. According to Deer, Howie, and Zussman $(1962$, v. 1, p. 206), relatively small contents of manganese give rise to strong absorption colors, and withamite may have only a fraction of a percent of manganese.

\section{CLINOZOISITE}

Clinozoisite occurs with other metamorphic minerals in the silicate replacement clumps that appear in the marble of the contact zone as far east as the nose of Nigger Baby Hill. In places it occupies a crude concentric band on one side of an epidote band which has garnet on the other side. The clinozoisite is in a fine-grained creamy-white to bluish-gray or greenish-gray aggregate. It is less common with other minerals in thin veinlets, and exceptionally, it forms small clear prisms, $1 \mathrm{~mm}$ long, in vugs in a garnetized porphyry. Its optical properties are variable and show gradation to epidote. However, it is not nearly so abundant or widespread as epidote. Fine-grained clinozoisite was found at one place in the Argentine tunnel intergrown with garnet bordering an igneous dike.

\section{CHLORITE}

In addition to its presence in Precambrian greenstone, metadiorite, and chlorite schist, and its ubiquitous occurrence as an alteration product of mafic minerals in monzonite and latite porphyry masses, chlorite is also a common mineral in the contactmetamorphic environment. It is intergrown with other minerals of this environment in the zone bordering the monzonite stock, extending exceptionally as far east as the nose above the Union Carbonate mine. It also occurs in both limestones and clastic strata in the environs of igneous dikes and sills in the mines up Silver Creek and of Nigger Baby Hill. Chlorite is present in the contact-metamorphic ores of the Atlantic Cable mine in the matrix of disseminated sphalerite. It is also present in the matrix of sphalerite-galena replacement ore in impure dolomitic limestone at the Falcon mine.

Variation from place to place in the optical character, birefringence, refractive indices, and less commonly, in color indicates that several mineral species in the chlorite group are present in the district. However, study has not been complete enough to demonstrate any segregation of differences in these features into specific environments.

TREMOLITE

Tremolite occurs as disseminated silky white fibers or tufts of fibers in metamorphosed Leadville and lower Hermosa limestones as far east as the nose of Nigger Baby Hill. It is also present with other metamorphic minerals in limestone bordering porphyry dikes and sills in the mines. It may also occur near the Blackhawk fault but not in known proximity to igneous bodies, as along the northwest crosscut off the St. Louis tunnel where it appears in the matrix of a metamorphosed arkose. Extinction angles on the fibers are commonly as much as $23^{\circ}$, and the high index of refraction $(n \mathrm{Z})$ is $1.63-1.64$, the latter figure indicating a composition that is transitional to actinolite.

\section{ACTINOLITE}

Actinolite is common among the products of igneous metamorphism related to the Rico stock or to the associated porphyry dikes and sills. In this setting, it shows virtually the same occurrence as tremolite but is less restricted to limestones. The two minerals intergrade isomorphously. The high index of refraction $(n Z)$ is 1.64-1.66. The fibers and needles in which it crystallizes are gray green and are commonly radiating.

\section{HORNBLENDE}

Black to grayish-green hornblende is an uncommon mineral of the contact-metamorphic zone bordering the monzonite stock. It may occur in clumps as much as 1 inch across in which individual crystals are a quarter of an inch across. In places, it may be intergrown with actinolite, or the actinolite may form prismatic extensions of the hornblende crystals. Hornblende is also a microscopic constituent in metamorphosed siltstone bordering a thick porphyry dike along the Blackhawk fault on the Blaine level of the Rico Argentine mine.

$$
\text { ALBITE }
$$

Albite occurs intergrown with other minerals of the metamorphic zone in areas close to the monzonite stock and is found as far east as the spur above the Union Carbonate mine. The coarsest material shows cleavage faces perhaps half an inch across. Two samples have been studied by David B. Stewart, of the U.S. Geological Survey.

In the first of these albite samples, from a prospect pit about 280 feet from the projected edge of the stock, the feldspar is associated with abundant magnetite, some pyrite, garnet, quartz, and a little calcite, and shows zebra rock banding with the magnetite. This assemblage replaces what appears to have been a greenish shale near the base of the Hermosa. The feldspar, according to Stewart (written commun., 1967) 
yields a sharp X-ray pattern indicating two feldspars are present in the sample. The sodic phase predominates. Patterns measured by Dora von Limbach were processed to yield unit-cell dimensions. The sodic phase ${ }^{3}$ is albite of intermediate structural state, showing anomalous unit-cell dimensions. The composition is estimated to be nearly pure albite from the unit-cell volume. The potassic phase ${ }^{4}$ is orthoclase, estimated to be $\mathrm{Or}_{92}$ in composition from the cell volume. The orthoclase dimensions are slightly anomalous, and it is probable that unmixing of the sodic and potassic phases is not complete. The original material was probably anorthoclase (or sodic sanidine). The bulk composition probably contains about $30 \%$ Or.

In the second sample, from the nose of the spur above the Union Carbonate mine, the feldspar is in small crystals whose roots form an interstitial matrix for fine garnet crystals in a vug. The feldspar crystals contain on their surfaces fine semihedral inclusions of diopside. According to Stewart (written commun., 1967), the X-ray pattern of the feldspar

is of below average quality, indicating some variability within the sample. Patterns measured by Margaret E. Hall were processed to yield unit-cell dimensions. The results ${ }^{5}$ indicate that the crystals are triclinic, very sodic $(\mathrm{Ab}>90)$, and that somewhat anomalous unit-cell dimensions are present. A few of the stronger lines of a monoclinic potassic phase were observed. The best interpretation of this data is that the sample is now antiperthite, containing albite of close to low structural state and orthoclase. It probably originally was an anorthoclase of intermediate structural state that contained some potassium (and calcium?) in solid solution.

POTASSIU,I FELDSPAR

Potassium feldspar is a constituent of metamorphic mineral assemblages in the contact zone near the monzonite stock, and also near porphyry masses in the mines. It is fine grained and generally recognizable only in petrographic thin sections. Masses that are dominantly this feldspar are dense and pale gray, but mixtures with other fine-grained minerals grade to masses in which the feldspar is only a minor constituent. In addition to replacement masses, the potassium feldspar may appear in replacement veinlets in the other materials.

In a dense-textured metamorphic rock derived probably from a silty phase of the Ouray Limestone and found on the dump of the Shamrock mine, the color grades from nearly black to nearly white. The mineral composition of both phases is very complex, but the whitish porcelainic phase is predominantly potassium feldspar. Under the microscope, grid
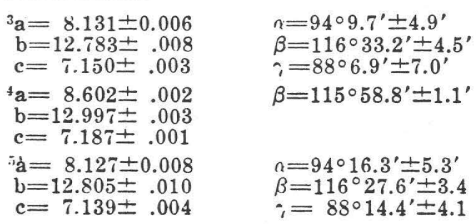

$\mathrm{Vol} .=663.05 \mathrm{~A}^{3} \pm 0.56 \mathrm{~A}^{3}$ (Std. error $=0.028^{\circ} 2 \theta$ )

Vol. $=722.29 \mathrm{~A}^{3} \pm 0.22 \mathrm{~A}^{3}$

$\mathrm{Vol} .=663.3 \mathrm{~A}^{3}$ (Std. error $=0.043^{\circ} 2 \theta$ ) twinning is only faintly perceptible in scattered spots. However, by X-ray diffraction study carried out by David B. Stewart (written commun., 1967), "the feldspar is unusually homogeneous intermediate microcline with relatively high obliquity, 0.70 . The cell parameters ${ }^{6}$ are those to be expected for such microcline that lacks perthitic albite. The composition is approximately Or $95 \mathrm{Ab}+\mathrm{An} 5$, judging from the cell volume."

Potassium feldspar also occurs with diopsidehedenbergite as a microscopic constituent of a baked shale close to the Blackhawk fault on the 500 level near the Argentine shaft projection, and it occurs with fine granular epidote in a metamorphosed limestone adjacent to the Nellie Bly fault nearby. The adularia form of potassium feldspar has been mentioned among the gangues of ore minerals (p.65).

$$
\text { ALLANITE }
$$

At one locality within 100 feet of the monzonite stock, 500 feet northwest of the Potter tunnel portal, considerable exploration by trenching has revealed the bedrock. Here, allanite occurs in irregularly rounded black grains as much as 1 inch across, intergrown with epidote and albite in association with garnet. X-ray fluorescence analysis by Robena Brown, of the U.S. Geological Survey, indicates the presence of cerium and lanthanum. The mineral is probably commoner than this one occurrence would indicate, as the contact zone next to the monzonite is for the most part concealed by surface wash.

BIOTITE

Biotite occurs in the matrix of certain dark hornfelses derived from siltstones in the contact zone bordering the monzonite stock and extending as far east as nearly to the New Demon mine. It is also present in similar environment bordering a dike in the Blaine tunnel. The mineral is fine grained, showing a maximum grain size of about $0.2 \mathrm{~mm}$.

\section{SERPENTINE}

Serpentine occurs as a replacement in basal Hermosa strata on the upper level of the Black Wonder prospect, about 250 feet from the monzonite contact. It is in part massive, containing granular magnetite and a little fine-grained dolomite, and in part in thin asbestos veinlets not more than an eighth of an inch thick. The nature of the original sedimentary rock has been obscured, but the rock was probably a shaly limestone.

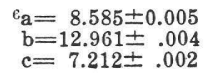

$\alpha=90^{\circ} 32.2^{\prime} \pm 2.7^{\prime}$, $\beta=115^{\circ} 54.4^{\prime} \pm 1.6^{\prime}$

$\mathrm{Vol} .=721.50 \mathrm{~A}^{3} \pm 0.35 \mathrm{~A}^{3}$ 
Rock samples from a prospect pit on the old road south of the Black Wonder portal, 250 feet from the monzonite contact, show an intergrowth of magnetite and coarse chlorite containing blebs, as much as half an inch across, of a dense, hard light-grayishgreen puttylike substance. An X-ray powder picture, made by Mary Mrose, reveals that this substance is a serpentine-group mineral near lizardite and clinochrysotile in its atomic spacings.

TOPAZ

Topaz has been identified from only a few localities, but the occurrences are very inconspicuous, so that the mineral may be more widespread than indicated. It was found in the Iron Rod workings which are just underneath the Princeton fault, 103 feet above the St. Louis crosscut to the Rico Argentine mine. The locality is $45-70$ feet from the Princeton fault, in its footwall, and 30-50 feet from the Blackhawk fault, in its hanging wall. The workings explore a thin pyritized zone in shale and sandstone of the lower Hermosa. The topaz-bearing zone is parallel to the bedding and appears to be an alteration product of a shale layer that may have originally been limy or dolomitic. This layer is pale gray to almost white and very compact, and chunks of it have an obviously high specific gravity. Microscopic examination shows it to be composed dominantly of topaz, but it also contains disseminated fine pyrite, muscovite, fluorite, diaspore, and rutile. The topaz is in a granular aggregate composed of very fine subhedral grains showing a maximum length of about $0.1 \mathrm{~mm}$ and a thickness of $1 / 2-1 / 4$ of the length. Although no igneous rock is exposed in the block of ground containing the topaz, a dike of alaskite porphyry can be projected into the footwall of the Blackhawk fault just beyond the limits of the mine workings.

Other occurrences of topaz are (1) 40 feet in the hanging wall of the Blackhawk fault on the Wellington tunnel level (north prong), and (2) immediately bordering the Blackhawk fault in the Blaine tunnel at the crosscut to the Iron raise. At these localities the topaz is similarly a microscopic constituent in pyritized strata and is associated with fluorite, muscovite, quartz, and, at the Wellington tunnel locality, diaspore. There is considerable latite porphyry along, and adjacent to, the Blackhawk fault at the Blaine tunnel locality.

Identification of the topaz from the mine workings above the St. Louis crosscut was made by Mary Mrose from a photograph of the X-ray powder pattern, after the rock was crushed and the minerals separated in heavy liquids.
DIASPORE

At the two localities where diaspore has been identified, it is associated with topaz, pyrite, muscovite, and fluorite. In the Iron Rod workings above the St. Louis crosscut to the Rico Argentine mine, the ensemble occurs as a dense pale-gray stratabound zone in metamorphosed shale (see preceding section on topaz), whereas the occurrence in the Wellington tunnel is in a pyrite-sericite replacement of limestone. The diaspore is somewhat coarser than the other constituents; in the Wellington tunnel occurrence it forms replacement blades as much as a quarter of an inch across in the sericite, or occurs in tabular crystals as much as three quarters of an inch across in vugs within the pyrite.

\section{ANDALUSITE}

The two known occurrences of andalusite are within 900 and 300 feet of the monzonite stock. A dark-gray hornfels sample from the dump of the Shamrock mine, and probably derived from the Ouray Limestone, contains several metamorphic minerals. The rock was originally a fine-grained impure siltstone containing detrital quartz grains. The matrix was replaced by such metamorphic minerals as andalusite, cordierite, potassium feldspar, tourmaline, biotite, phlogopite, and a fine magnetite dust. The andalusite is in anhedral to subhedral elongated grains tending toward square cross section, and as much as $0.5 \mathrm{~mm}$ long. These grains contain rounded inclusions of potassium feldspar forming a poikilitic texture. Some of the andalusite shows incipient alteration to a fine sericite along certain crystallographic directions.

Andalusite also occurs as a microscopic constituent in a finely sericitic phase of the Larsen Quartzite from the Black Wonder mine dump. Here, it contains poikilitic inclusions of secondary quartz and is associated with a little fine disseminated magnetite and biotite.

\section{CORDIFRITE}

Cordierite occurs with andalusite, biotite, phlogopite, tourmaline, secondary quartz, and fine magnetite in the matrix of a metamorphosed siltstone from the dump of the Shamrock mine (see andalusite). It is in indefinite anhedral grains, commonly finely granular, and rarely as much as $0.2 \mathrm{~mm}$ across. The larger grains contain numerous inclusions of a fine fiberlike mineral, not identified (sillimanite?), and uncommon inclusions of zircon. The zircon produces pleochroic halos that are characteristic of cordierite-a deep yellow halo when the polarized light vibrates parallel to the fast ray di- 
rection, and colorless when parallel to the other directions.

$$
\text { TOURMALINE }
$$

Tourmaline is not common, but occurs at the Shamrock mine in dark hornfels that contains some fine detrital silt and was evidently derived from an impure phase of the Leadville-Ouray Limestones. The tourmaline is associated with several other metamorphic minerals, including andalusite, cordierite, and potash feldspar, in a complex finegrained aggregate. It occurs in very small prisms, not more than $0.1 \mathrm{~mm}$ long, and is blue gray or blue green in microscopic section. Some of the prisms are peppered with very fine grained magnetite inclusions.

\section{PREHNITE}

The only prehnite found in the district was in the matrix of a baked limy arkosic siltstone on the spur above the Union Carbonate mine. Here, it is in anhedral grains as much as $3 \mathrm{~mm}$ across and is associated with interstitial calcite.

$$
\text { RUTILE }
$$

Rutile occurs in very fine needles in chlorite from the dump of the Potter mine, near the monzonite contact. Similar needles are associated with topaz and diaspore on the Iron Rod level above the St. Louis crosscut to the Rico Argentine mine, near the Blackhawk fault. Probably the mineral is commoner than suspected but is so fine grained as to be inconspicuous.

$$
\text { SPHENE }
$$

In addition to its common occurrence as an accessory mineral in the monzonite and latite porphyry, sphene is a commonly scattered fine-grained mineral in the contact-metamorphic aggregates related to the monzonite and bordering igneous bodies in the mines. Its occurrence in veinlets with other metamorphic minerals suggests that it was deposited in the metamorphic sequence and is not residual from a detrital occurrence in the sediments.

\section{SUPERGENE MINERALS}

Although some oxidized ore deposits were worked for silver in the early history of Rico, such deposits were largely worked out and have been inaccessible for many years. Some of the ores taken from the - Forest Payroll mine in recent years have been oxidized or partially oxidized. Elsewhere in the district, the superficial parts of veins and blanket deposits have contained supergene minerals, but they have been of little economic importance.
LIMONITE

Hydrated oxide of iron is common in the district, particularly where pyritic replacement masses underlie thick surficial debris, as on parts of $\mathrm{CHC}$ Hill. Such debris retains the surface water and allows it to percolate slowly through the underlying ground, thoroughly oxidizing the sulfides. The upper parts of pyritic veins also contain limonite where they have been exposed to weathering.

ANGLESITE

Anglesite is an alteration production of galena at the Forest Payroll mine and at a few surficial prospects in the district. It is commonly a fine-grained ash-gray to pale-gray crust, but locally may be in very small crystals of adamantine luster.

CERUSSITE

The common alteration product of galena is cerussite, which may occur as black spongy masses of finely crystalline carbonate containing impurities, or as clear crystalline material. The crystalline material is in white to cream-colored aggregates, or it may be in needles or prisms having a silky luster.

SMITHSONITE

Doubtless, smithsonite is common in oxidized ground that is no longer accessible. Scattered small pockets of a pale-flesh-colored "drybone" type of smithsonite are found in parts of the Revenue mine but are hardly noticeable in the dominantly sulfide ore.

\section{MALACHITE}

Green stains of malachite are common in many pyritic stopes where they were formed from chalcopyrite, probably after the sulfides were exposed to oxidation by mining operations. Malachite is also widely distributed as small green specks in oxidized ores but is not a very abundant mineral in the district.

SERPIERITE

Serpierite, a hydrated basic sulfate of copper, zinc, and calcium, occurs sparingly in the oxidized veins at the Forest Payroll mine. It forms a coating of greenish-blue pearly scales on oxidizing sulfides that include sphalerite, chalcopyrite, and galena.

GYPSUM

Gypsum is a common alteration product in oxidizing pyritic masses.

PYROLUSITE

Oxidation of veins carrying rhodonite, rhodochrosite, or the ubiquitous manganiferous calcite leaves 
a black earthy residue that is predominantly pyrolusite. Commonly, the mineral exists as little more than a stain on other resistant materials. The black manganese oxide that contains iron was presumably derived from manganiferous siderite, and there are all gradations to a black limonite.

\section{PARAGENESIS}

The sequence of mineralization that is genetically related to the monzonite stock has not been worked out in detail because many of the minerals show no, or only limited, association with others of the suite. In conformity with sequences that have been amply demonstrated elsewhere, it is presumed that, as a general class, the contact metamorphic minerals are earlier than the sulfide and gangue minerals. For limited pairs or groups, this is very evident. Thus, the garnet is commonly broken or shattered in such a way as to suggest that it was earlier than other metamorphic silicates such as epidote, actinolite, chlorite, and diopside and earlier than specularite, calcite, quartz, and sulfides, all of which have crystallized around, or through, its broken masses. Garnet was also earlier than albite, which crystallized between garnet crystals in vugs on the spur above the Union Carbonate mine. The magnetite and fine apatite, on the other hand, are embedded in the massive garnet, suggesting near contemporaneity of these three, and the occurrence of magnetite as the host for epidote veinlets also suggests it is early.

Specularite, though later than garnet, is generally early in the sequence. It is cut by later tufts of chlorite. In sulfide ores containing iron oxides, part of the specularite has altered pseudomorphously to magnetite. Also, at one locality on the Blaine level. the bladed specularite associated with garnet in a metamorphic zone bordering a thick igneous dike has been altered to magnetite.

A minor occurrence of magnetite and specularite in what was originally limestone bordering a porphyry dike, exposed on the Argentine level of the Rico Argentine mine, is probably contemporaneous with pyrite and siderite. Here, the iron oxides occur with the siderite in very irregular anastomosing "segregation veinlets" in the massive pyrite. The texture, but particularly the mineral association, resembles that which Edwards (1954, p. 122-123) ascribed to replacement of pyrrhotite by pyrite, the excess iron being segregated in interstitial oxide and carbonate.

In the only observed occurrence of pyrrhotite, the massive mineral encloses cubic crystals of pyrite, but it also is host for crosscutting shear veinlets containing pyrite, quartz, and a little chalcopyrite, and for similar crosscutting veinlets containing magnetite. Thus, with the possible exception of the cubic pyrite, the pyrrhotite is earlier than the other minerals mentioned.

Euhedral crystals of quartz that appear in pyrite, sphalerite, and galena are probably earlier than these sulfides, but quartz is a long-ranging mineral that can also appear late in the sequence. Certainly, in some areas, crystalline spalerite is banded by thin veins of quartz that are definitely later than the sphalerite.

In contrast to the fairly common occurrence of small vugs in the monomineralic pyritic masses, the zinc-lead ores are relatively free of vugs. Hence, the evidence of a paragenetic sequence in the crystallization of the different minerals is not abundant. In such ore deposits, pyrite was on the average the first mineral to crystallize, followed by sphalerite and galena, but there was doubtless much overlap in sequence. Sphalerite crystals have been found perched on top of pyrite pyritohedrons in vugs, and both sphalerite and galena form veinlets, commonly parallel to the bedding of the replaced limestone, in the massive pyrite. In polished sections of the compact replacement ore, pyrite appears in part as anhedral grains intergrown with, or included in, the other sulfides, but it tends also to form euhedral or subhedral grains in the sphalerite, galena, and chalcopyrite. It may, in turn, contain small anhedral inclusions of these minerals, and it also contains ribbonlike linear inclusions or veinlets of them (which may show pinchout discontinuities), suggesting crystallization or, locally, some breakage of the pyrite before deposition of the others. In rare instances, pyrite appears as late minute veinlets extending out from larger inclusions in sphalerite, and it may occur in thin quartz veinlets in sphalerite. Ransome (1901, p. 271-272) considered that quartz and pyrite were the last minerals to crystallize in Newman Hill, even postdating the silver sulfide minerals.

The crystallization sequence between sphalerite and galena is suggested in certain textural relations revealed in polished section. The two minerals commonly show a mutual boundary along which they may be intricately intergrown, and each has anhedral inclusions of the other. However, the general nature of these inclusions differs, depending on which is the host mineral. Inclusions of sphalerite in galena are commoniy rounded grains, or what can be interpreted as an agglomeration of rounded grains wherein the overall boundary is a number of convex scollops that intersect in sharp points directed inward. On the other hand, inclusions of 
galena in sphalerite are very irregular, commonly elongated, and the overall boundary is, in general, a series of concave scollops intersecting in sharp points directed outward. The galena commonly extends into, or through, the sphalerite in elongate irregularly vermiform veinlets of varying width and with sharp terminations, or in discontinuous veinlets of this type. The logical interpretation is that the sphalerite has crystallized first from one or more centers, the grains coalescing along boundaries that are no longer evident in polished section, and the galena crystallized later in the interstitial space.

Chalcopyrite contains anhedral blebs of pyrite, sphalerite, and galena. It may appear as anhedral inclusions in these minerals, particularly near the edges of grains, but it also occurs as veinlets in the pyrite and sphalerite. It appears to be roughly contemporaneous with the galena and commonly occurs with this mineral in the vermiform veinlets in sphalerite.

Tetrahedrite-tennantite occurs as anhedral grains of very irregular shape in sphalerite, galena, or chalcopyrite; its larger grains; in turn, contain anhedral inclusions of these minerals. It occurs in sphalerite in the same type of irregular discontinuous vermiform veinlets as the galena, in part associated with galena or chalcopyrite, suggesting that it is later than the sphalerite. In one polished section, a veinlet of chalcopyrite in sphalerite detours around the border of an intersected tetrahedrite-tennantite grain, indicating that here the chalcopyrite was later. Probably the tetrahedritetennantite was about contemporaneous with the galena.

The few occurrences of cosalite observed were blebs associated with fluorite in granular massive cubic pyrite, replacing limestone. Polished sections show the cosalite to be mostly anhedral against crystal edges of the pyrite, but locally the two sulfides have a mutual anhedral boundary along which the cosalite forms small anhedral inclusions in the adjacent pyrite. A little chalcopyrite is intergrown anhedrally with the cosalite, and probably these two minerals were nearly contemporaneous.

On the basis of their occurrence on the borders of crustified veins in the Pro Patria and Revenue mines in Newman Hill, rhodonite and rhodochrosite were apparently earlier than the sulfides, and Rickard (1897, p. 979) considered rhodochrosite to be earlier than the "baser" sulfides in the Enterprise mine of this general area. On the other hand, dolomite, calcite, and fluorite are generally later than such common sulfides as pyrite, spalerite, and galena, to judge from their common occurrence in vugs in these sul- fides. At one place on the $\mathrm{C}$ bed level of the Mountain Spring mine, near the Blackhawk fault, $1 / 2$-inch cubes of fluorite are deposited over and hence are later than $1 / 8$-inch scalenohedrons of calcite.

The position of barite in the sequence relative to the sulfides is unknown. However, it was evidently early in the sequence of mineralization and was unstable at some later stage, for it has been leached at several places where only the accidents of pesudomorphism leave a record of its former presence. It was earlier than quartz, which coated it, and after leaching of the barite, calcite was deposited in the hollow casts.

Although the occurrence of the silver-bearing sulfides could not be studied as part of the present report, both Rickard (1897, p. 979) and Ransome (1901, p. 253) agreed that these sulfides were the last ore minerals to be deposited in the Newman Hill ores. They occur there in vuggy centers of the veins in association with late quartz.

In summary, a generalized paragenetic order for some of the ore and gangue minerals may be about as follows: Quartz, rhodonite and rhodochrosite; pyrite; sphalerite; galena and tetrahedrite-tennantite; chalcopyrite and cosalite; dolomite and calcite; fluorite; silver sulfides (argentite, prousite, pearceite, polybasite) ; pyrite and quartz. Pyrrhotite and the iron oxides are earlier than the other sulfides enumerated, but their relation to the early quartz and manganese minerals is not known. There are doubtless local reversals in order because of aberrations in relative concentrations of the different elements in the depositing solutions and also because of temperature variations; the order given can represent only an average.

\section{TYPES OF ORE DEPOSITS \\ MASSIVE SULFIDE REPLACEMENT DEPOSITS CHIEFLY IN LIMESTONES OF HERMOSA FORMATION}

The major ore deposits of the Rico district occur as replacement bodies in the limestones of the middle Hermosa where they are broken in the neighborhood of certain faults. The Blackhawk fault has been a dominant trunk channel for the introduction of ore solutions. However, the specific channels followed by the mineralization are as likely to be the smaller breaks tributary to the Blackhawk. Thus, most of the ore taken from the Mountain Spring and Wellington mines since World War II was centered on a small fault trending parallel to the Blackhawk but located 900 feet northeast of it on the Mountain Spring level. The contacts between limestones and porphyry dikes or sills are also common sites for ore localization. Another system of 
fractures, closely related to the Last Chance and Yellow Jacket faults, was responsible for the deposits worked in the Yellow Jacket mine in Nigger Baby Hill. Smaller replacement deposits at other scattered localities indicate a widespread dispersal of the ore solutions along various breaks.

Although the Princeton fault was an early break, it apparently had no mineralizing influence whatsoever. Its large displacement separated the limestone terrane into two blocks of ground which were later mineralized by ore solutions associated with the transcurrent Blackhawk fault. The footwall block of the Princeton fault contained the extensive deposits that were worked for many years in CHC Hill. The ore-bearing strata here are relatively flat lying, though broken by many small faults and fractures. This ground is now believed to be virtually exhausted. The hanging-wall block contains the deposits that were first recognized and mined in various levels of the Rico Argentine mine along Silver Creek. Driving of the St. Louis tunnel under CHC Hill with a crosscut to Silver Creek has simplified the drainage problem, and current mining effort is largely directed toward following the mineralized beds downward on their northward dip toward the Princeton fault. In both the CHC Hill and Silver Creek areas, the limestones have been mineralized on both sides of the Blackhawk fault, which has moderate to negligible displacement along different parts of its extent. Other fractures, however, break the ground into numerous blocks, which has greatly complicated the exploration and mining problems.

The dominant sulfide minerals in the replacement ores are pyrite, sphalerite, galena, and chalcopyrite. The galena is moderately argentiferous. Tetrahedrite, which carries more silver, is widely though unevenly distributed, mostly in microscopic grains, but local enrichments of coarser material are manifested in certain "rich-silver" stopes. Rare sulfides include alabandite $(\mathrm{MnS})$ and cosalite $\left(\mathrm{Pb}_{2} \mathrm{Bi}_{2} \mathrm{~S}_{5}\right)$. The gangue minerals include commonly quartz, fluorite, calcite, dolomite, siderite, rhodonite, sericite, and sparse apatite. Although rhodochrosite is an uncommon gangue mineral, the calcite and other carbonates generally contain appreciable manganese. Rare gangue minerals include huebnerite and sellaite $\left(\mathrm{MgF}_{2}\right)$. Certain contact-metamorphic silicates and iron oxides may occur sparingly in, or closely adjacent to, massive sulfide ores, but they are local and are best considered to be of accidental association, related to higher temperatures through which the local deposition site passed prior to the mesothermal sulfide mineralization.

In ground of intense mineralization, the replace- ment by sulfide minerals may also extend irregularly, though most commonly as disseminations, to porphyry bodies, arkoses, sandstones, and shales. In places, the porphyry adjacent to replaced limestone has been minable as ore. Sericite is particularly abundant as a gangue in the porphyries and arkoses.

Many of the sulfide bodies are solely pyrite that has selectively replaced certain limestone beds sharply to their upper and lower boundaries over considerable areas, yielding thick tabular bodies. Where less than the complete thickness of a limestone bed is replaced, the upper part is favored. Some of these sulfide bodies are almost pure granular and porous pyrite in which the grains are commonly $1 / 8-1 / 2$ inch across, sometimes as much as 3 inches (rarely, 6 in.); but most of these pyrite bodies contain a little interstitial sericite, and pockets and lenses of fluorite, calcite, dolomite, or quartz are commonly associated. Fluorite lenses may be 2 feet long. The fluorite may also be interbanded with the pyrite on a fraction-of-an-inch scale. These pyrite masses, which are best developed in CHC Hill, became the basis for the sulfuric acid industry after attempts at recovery of the pyrite from tailings piles at the lead-zinc mill proved unsuccessful. Although the structural breaks localizing the pyrite bodies have in many places been so modified by the mineralizing solutions that they have become obscured, in other places a fracture or small fault on which the mineralization is symmetrically centered is still evident. Some contraction in the thickness of the stratigraphic unit accompanied the pyritization, amounting to perhaps 10-35 percent.

Sphalerite and galena are closely associated in the massive sulfide deposits. They are characteristically massed at the outer periphery of a pyrite body where they are commonly bordered on their outer wall by unaltered limestone. Such localization gives an important clue for exploration where pyritic masses are known, for the bordering zinclead ore bodies may be confined to relatively narrow ore runs that may, however, encompass the complete thickness of limestone bed. Sphalerite and galena are also commonly massed at the tops of pyritized beds, and in occurrences where the sulfides have not replaced the complete thickness of the limestone, they may also be concentrated at the limestone contact on the lower side of the pyritic body. Generally, the sphalerite and galena are mixed with far more abundant pyrite. The galena tends to form thin veinlets in the sphalerite or pyrite parallel to the bedding of the original limestone.

Nearly all the pyritic masses contain a little chalcopyrite, which oxidizes to give a green copper stain 
that is conspicuous in the old mine workings. Local increase in the percentage of chalcopyrite yields an exploitable copper ore, generally, though variably, argentiferous, distinguishable from submarginal pyritic material only by assay. Although most of the copper ore is segregated in such pyritic masses, nearly all the zinc-lead ore bodies contain a little chalcopyrite.

The grade of ore from the replacement deposits has varied with different stopes. Although the crude ore is not assayed, an approximation can be calculated for the average mill feed at the Rico Argentine mill over several years by relating the assays of marketed concentrates to the weight of crude ore and allowing for milling losses. In the 5 years 1952 56 inclusive, when 97 percent of the ore (total, 192,947 dry tons) came from the limestone replacement deposits in CHC Hill and near the Argentine mill up Silver Creek, the ore averaged, per short ton, approximately 0.0035 ounce gold, 3.5 ounces silver, 6.2 percent lead, 8.4 percent zinc, and 0.06 percent copper. This grade is somewhat lower than that in preceding years 1939-51 inclusive, when the mill feed averaged for the 13 years 0.004 ounce gold, 4.8 ounces silver, 7.2 percent lead, 11.85 percent zinc, and 0.5 percent copper. In these earlier years, however, considerable ore of other types, and particularly the contact-metamorphic ore from the Atlantic Cable and Van Winkle shafts, was included in the mill feed. This fact does not necessarily imply, however, that the contact-metamorphic ores were any richer than the other limestone replacement ores mined at that time.

The zinc concentrates carry cadmium; those marketed in March-June, 1969, from the Silver Creek area contained $0.31-0.35$ percent $\mathrm{Cd}$ (and $53-55$ percent $\mathrm{Zn}$ ). The lead concentrates for the same period contained 0.03-0.04 percent As, 0.09-0.45 percent $\mathrm{Sb}$, and 0.064-0.106 percent $\mathrm{Bi}$ (and 71-76.5 percent $\mathrm{Pb}$ ). The higher antimony content coincided with a temporarily high silver content, suggesting the presence of tetrahedrite in the ore.

\section{CONTACT-METAMORPHIC DEPOSITS}

Contact-metamorphic deposits occur in the marbleized Leadville and Ouray Limestones and in the basal Hermosa Formation within 2,000 feet of the monzonite lobe at Rico. The Shamrock and Atlantic Cable mines exploited typical ores of the type, and the Van Winkle shaft ores also appear to be predominantly of this type. None of the deposits have been accessible for examination by the author. Parts of the Atlantic Cable mine were mapped in 1943 by
Varnes (1944), and the following paragraph is abstracted from his work.

The ores are sphalerite, galena, and chalcopyrite which occur in irregular pods scattered through a mass of specularite, magnetite, and chlorite replacing the Leadville-Ouray marble. Pyrite and a quartz silicification are abundant with the ore. At many places a band of sphalerite and galena 1 inch to 1 foot thick lies along the contact between the iron oxides and the marble. The iron oxide body is in a linear zone varying in width, as wide as 100 feet on the upper levels, and following a system of northwesterly fractures of moderate to steep dip which contain quartz or gouge and, locally, sulfides. The mine workings are on three levels, encompassing a vertical interval of about 150 feet. The mineralized zone has been developed over a length of nearly 400 feet on the upper two levels.

Company mapping in the Shamrock mine suggests that the ore is similar to that in the Atlantic Cable but is localized on fractures running more nearly east-west. Specimens of sphalerite from the dump show a mixture of rosin, black, and very pale colored sphalerite. Some manganiferous siderite occurs in the chlorite matrix and also as fine crystals in vugs. Manganiferous calcite is also a gangue mineral. Company maps prepared in 1925 show an estimate of 3,000 tons of ore at one place averaging 5.72 ounces silver, 6 percent lead, and 10.23 percent zinc. As the mine was worked on a substantial scale through 1927 and at a reduced scale into 1929, this ore has probably been mined.

Polished sections of the Shamrock ore show that chalcopyrite tends to segregate on contacts between sphalerite and galena or between sphalerite and quartz grains. The sphalerite masses contain small irregular or discontinuous linear inclusions of galena and chalcopyrite, in some instances associated in the same inclusion or veinlet. The chalcopyrite inclusions are in part minute parallel laths or blebs in parallel lines, which probably are of exsolution origin (Edwards, 1954, p. 98-102). The larger masses of galena contain inclusions of sphalerite and chalcopyrite, in part mixed in the same inclusion.

Although contact-metamorphic gangue minerals are found in the Rico Argentine mine workings on Silver Creek, no ore deposits of any consequence are known in this association there. The gangue minerals are replacement masses commonly on the boundary in contact with porphyry bodies, but may be segregated in limestones only in the general vicinity of such bodies in the hanging wall of the Blackhawk fault. Garnet, specularite, epidote, actinolite, 
chlorite, fine apatite, and diopside-hedenbergite are common. Massive or cubic pyrite is ubiquitous in this association and locally contains, or is associated with, a little chalcopyrite, sphalerite, and galena. Magnetite is a sparse component. Coarsely crystalline calcite is generally present in the aggregates and commonly contains enough manganese to be pink. The sulfides occur with the calcite in the interstices between the garnet or diopside-hedenbergite masses.

\section{VEINS IN HERMOSA SANDSTONES AND ARKOSES}

Most of the faults and fractures in the Rico district contain gangue minerals and some pyrite. Many also contain sphalerite, galena, chalcopyrite, and locally, other sulfide minerals. In Newman Hill, several silver-bearing sulfides in addition to the common base-metal sulfides made the veins of this area exceptionally rich, but these ore deposits were largely exhausted by 1900 . Elsewhere in the district, the veins in clastic strata of the Hermosa Formation have for the most part been too low grade in silver and to thin to be economically exploitable, except where they were enriched by oxidation, as at some of the veins worked early in Nigger Baby Hill. Locally however, unoxidized veins have been mined for short distances, particularly where they are followed by development workings. Where the veins are in limestone, they commonly widen into replacement ore. In the sandstones and arkoses they are generally less than 1 foot thick, but may in places attain 2 feet, in which case they may be stoped, but generally for lengths of 100 feet or less. Where the veins cross shales, they are too thin and tight to be of any economic interest. Although nearly all orebearing veins are on faults, these are faults of small displacement, and the profound breaks that account for the structural pattern of the district, as discussed in the section on "Structure," are barren.

The mine workings of Newman Hill are no longer accessible, but the veins have been ably described by Farish (1892), Rickard (1897), and Ransome (1901), from whose accounts the following summary is abstracted.

The productive veins, about a dozen, are in a northeast-trending system and are nearly vertical. They occur on faults of very small displacement, less than 10 feet, in sandstone and arkose containing a few thin limestone beds in the lower Hermosa, above the thick porphyry sill of Newman Hill. They average about 6 inches thick; some reach a thickness of 18 inches and rarely, 2 or 3 feet. The common sulfides include pyrite, sphalerite, galena, and chalcopyrite; but the value of the ore was contained largely in several silver-bearing sulfides, including tetrahedrite, tennantite, argentite, proustite, polybasite, pearceite (Bastin, 1922), and stephanite. Some free gold and native silver are also reported. Representative assays ran 45-75 ounces silver and 0.3-0.5 ounce gold per ton of ore. The gangue minerals were predominantly quartz and rhodochrosite, according to the cited reports, but the presence of rhodonite on some of the dumps shows that this mineral was also present. Crustification of the veins was particularly emphasized by the striking contrasts in color of the different ore and gangue minerals. The silver-bearing minerals were particularly concentrated in the vuggy centers of the veins, and are considered to be of late hypogene origin. The latest material to crystallize, however, was barren quartz and pyrite.

The ore veins were broken and partly dislocated by a system of barren veins striking northwest and dipping most commonly northeast at $40^{\circ}-90^{\circ}$. These cross veins contained mostly quartz and pyrite and were on faults of somewhat larger displacement, though not exceeding 25 feet. Opinions differ whether the northwest-trending faults were younger than the northeast-trending faults that carried the veins (Rickard, 1897, p. 940-960) or whether both sets of faults were contemporaneous, the northwesttrending faults being mineralized later (Ransome, 1901, p. 271-272). The latter view reconciles most of the conflicting features that need explanation. Owing to differences in pressure distribution with time, the premineral breaks of one system may not open contemporaneously with those of another system, but changing pressures may allow them to open later. Ransome pointed out that the mineralization of the northwest-trending fissures by quartz and pyrite may have been contemporaneous with the final barren phase of the same mineral composition in the northeast-trending fissures.

The ore veins were confined to a stratigraphic interval of about 150 feet in the lower Hermosa. The veins topped about 5-20 feet below the Newman Hill "contact," a richly mineralized replacement zone in the debris residual from the solution of a sedimentary gypsum bed. Between the tops of the veins and the "contact" lay a shaly zone unfavorable for fracturing, through which extended only minor irregular and branching stringers representing impoverished extensions of the underlying veins. The bottoms of the veins were at an indefinite level, below which the silver-bearing sulfides gave out, though base-metal sulfides, pyrite, and barren quartz persisted lower (Ransome, 1901, p. 317-318). The rich silver lodes in Newman Hill extended northeast 
approximately to a northwest crosscut from the Laura shaft, beyond which the veins lost most of their silver content.

\section{REPLACEMENT DEPOSITS IN RESIDUAL DEBRIS} RESULTING FROM SOLUTION OF GYPSUM BED

The rich silver replacement deposits of the socalled "contact" or "Enterprise blanket" in Newman Hill were of a unique type. Although the ores were practically exhausted by 1900 and the workings are no longer accessible, excellent accounts have been published by Farish (1892), Rickard (1897), and Ransome (1901). Only a short summary based on their work will be given here.

The ores were hypogene replacement deposits in the porous debris that was left after the solution of a bed of gypsum near the middle of the lower Hermosa. Part of the debris was slump breccia from the immediately overlying strata consisting of shales and, locally, thin-bedded sandstones, but most of the ore was in a residual silt consisting predominantly of fine granular dolomite and celestite at the base of the dissolved gypsum. Although commonly described as blanket deposits, the contact deposits had linear dimensions defined by the positions of the underlying veins. Thus, a typical contact deposit was a ribbonlike body a few inches to 6 feet thick, as much as 40 feet wide centered on the apex of an underlying vein, and several hundred feet long following the strike of the vein. In shape, it was more comparable to the runs that characterize the TriState ore deposits, or to the more linear mantos of western replacement ores. Surprisingly, the contact deposits capped the northwest-trending barren veins as well as the northeast-trending productive ones, and were equally as rich, or even richer, over the barren veins. This fact tends to confirm Ransome's (1901, p. 271-272) surmise that the breaks of the northwest-trending fissure system were as early as those of the northeast-trending system. In mineralogic composition the contact ores were similar to the northeast-trending veins, though the proportions were somewhat different. They were the richest ores known in the district, a representative analysis running 221.5 ounces silver and 0.87 ounce gold per ton of ore.

The contact zone was immediately overlain by fissile black shale which was generally impervious to descending ground waters and thus protected both the contact ores and underlying vein ores from oxidation. The shale held the further practical advantage in that it kept the mine workings relatively dry.

\section{PREVALENCE OF CARBON DIOXIDE}

Carbon dioxide gas bubbles up from several natural springs along the valley floor of the Dolores River at Rico and is also commonly found in the mine workings of the district. Any unventilated winze or sump is likely to accumulate this heavy gas to the exclusion of normal air. Evidently, the carbon dioxide comes out of cracks in the bedrock and flows like an invisible liquid into low places, failing to mix with air because of its weight and laminar flow with a minimum of turbulence. The upper surface of the gas in stagnant workings is a horizontal plane of remarkable sharpness. The gas filles a depression to the lip and then flows out in a stream only a few inches thick along the floors of connecting drifts and adits. If entryways are undisturbed, the carbon dioxide may remain sharply segregated on the floor and become a death trap to any bird that tarries too long at the floor of the portal. The natural springs along the edge of the valley floor west of the river at Rico are particularly enticing to small birds, which fall victim to the invisible layer of carbon dioxide that flows out of the orifice, just above the trickle of water that has attracted them to drink or bathe. Carbon dioxide in abandoned mine workings is equally dangerous to humans who explore with electric lamps. The carbide lamp, because of its delicate response to varying degrees of oxygen deficiency, provides a large measure of safety.

Pelleyre diamond-drill hole 1 , drilled in 1939 at a very steep angle from a point 1,940 feet inside the Lexington tunnel in Newman Hill, struck a heavy flow of carbon dioxide gas at 798 feet. This flow was at 86 feet below the base of the thick Newman Hill porphyry sill, and was believed to be from the lower part of the Hermosa Formation. The blast was strong enough to blow water back out of the hole. After some difficulty the hole was deepened, and it had penetrated 20 feet into the Uncompahgre Quartzite at 1,119 feet when more gas was found than the ventilating fan could dispose of safely. The hole was abandoned at this depth.

\section{MINES}

In the following pages, only those mines are discussed that have been accessible during the fieldwork on which the present report is based. In general, only mines that were worked during or since the 1920's are included, but not all of these have been accessible. An omission that is particularly regrettable because it represents a type of deposit not fully covered otherwise is the Van Winkle mine, worked through a shaft during World War II. How- 
ever, workings from the Atlantic Cable shaft, which exploited a similar type of deposit, were partly accessible to D. J. Varnes in 1943 (1944), and an abstract of his report is here included.

The rich silver mines of Newman Hill were largely exhausted by the time of Ransome's (1901) report, which gives full and adequate treatment of their geology. Many other mine workings throughout the district are also described fully in that report. No attempt is made in the present report to summarize the early history or to repeat the descriptions of abandoned mines, even in areas of current mining operations. The reader is referred to the Ransome (1901) report for the early details.

\section{MOUNTAIN SPRING-WELLINGTON GROUP}

The Mountain Spring and Wellington tunnels are on the slope of CHC Hill, on the east side of the Dolores River about 1.5 miles north of Rico. The tunnels enter the hill in a general east-northeast direction; their portals are at altitudes of 9,433 and 9,725 feet, respectively. The Wellington portal is slightly south of the Mountain Spring adit line (pl. $2 C$ ), and the Wellington adit follows a more easterly course so that the two tunnels do not cross until the general neighborhood of mineralized ground at the Blackhawk fault is reached.

The Mountain Spring tunnel is cut in lower Hermosa strata until the Blackhawk fault is crossed, 2,120 feet from the portal. The fault here has a displacement of about 250 feet, down on the northeast. A short distance beyond the fault, the level workings explore the A bed, at the base of the middle Hermosa (pl. 2C). Higher beds in the middle Hermosa between the Mountain Spring and Wellington levels were developed on the downthrown side in the vicinity of the fault, and much zinc-lead-silver ore was taken out. Producing units ranged from the C to I bed; the most productive were $\mathrm{D}, \mathrm{E}$, and I. One stope in the upper part of $\mathrm{E}$ bed was 230 feet long, as much as 75 feet wide, and a maximum of 9 feet high. The "old zinc stope" in the I bed was 450 feet long, as much as 60 feet wide, and 9 feet high. These ore bodies were at the outer northeast edges of pyrite masses that completely replaced the respective limestone beds outward from the Blackhawk fault. Although the fault was generally avoided in the intertunnel workings, projections from the two main tunnel levels indicate that the zinc-lead bodies were parallel or subparallel to the fault and within 150 200 feet of it. As the mineralization was not coextensive in the different stratigraphic units, the different stopes are not generally superposed or regularly offset from each other. However, the main stopes in the D and $\mathrm{E}$ beds show considerable overlap.

The stopes and development workings between them reveal numerous irregularly spaced small faults striking nearly parallel to the Blackhawk fault and showing displacements of 1-5 feet, generally down on the southwest side. One fault in this system, however, shows a larger displacement, amounting to about 70 feet. On the Mountain Spring level, this fault, the Mountain Spring, branches from the Blackhawk fault near the main adit crossing and diverges northward at an acute angle into the hanging wall of the Blackhawk fault (pl. $2 C$ ). As it dips $50^{\circ}-82^{\circ}$ in the opposite direction from the Blackhawk, it passes over the large stopes in the $\mathrm{D}$ and $\mathrm{E}$ beds, which are southeast of the Mountain Spring adit, and passes under the "old zinc stope" in the I bed, which is mostly northwest of this adit.

Southeast of the zinc-lead (-silver) stopes, on the approach to the Princeton fault, the A bed in the hanging wall of the Blackhawk fault was mineralized by massive pyrite containing enough copper in places to be minable. The stoped ground is about 50 feet above the southeast drift of the Mountain Spring level.

Old mine maps of the Wellington mine show extensive stopes also in the footwall of the Blackhawk fault. These stopes were inaccesible by 1930 , and the mine maps are incomplete, lacking altitudes among other things; hence, details of the geology are lacking. One large stope above the Wellington level is parallel to and within 200 feet of the fault. A much larger stope, or series of stopes, is parallel to the fault where this stoped zone crosses the two main prongs of the Wellington tunnel about 550 feet from the fault, but swings at the southeast end to within 200 feet of the fault. The northwest end is open and is reported to connect with old stopes in the Logan mine. Between the two prongs of the Wellington tunnel, the existing mine map shows the stope to be 40 feet below the Wellington level. Mapping on this level and in a winze that was accessible in 1931 indicates that the ore in this block of ground was in the A bed. Exposed on the level are several closely adjacent faults of small displacement (14 to perhaps $20 \mathrm{ft}$ ), all in a system parallel to the Blackhawk fault dipping northeast or vertically ( $\mathrm{pl} .2 C$ ), and these faults must cut the stoped ground below the level. The swing in stope plan at the southeast end is doubtless explained by a small transcurrent fault that was formerly exposed in workings on the Wellington level near the point where the change in direction takes place. Presumably, the stopes in this old ground were largely in zinc-lead (-silver) ore. 
Since the early 1930's, the main tunnels of the Mountain Spring and Wellington mines have pushed well beyond the Blackhawk fault. Another fault of nearly parallel strike, but having opposite displacement down on the southwest of a few tens of feet, was crossed on the Mountain Spring level about 500 feet beyond the Blackhawk fault, at $20,110 \mathrm{~N}$, $17,150 \mathrm{E}$, (pl. $2 C$ ). This fault shows no mineralization in the A bed on this level nor in the $\mathrm{E}$ bed on the Wellington level, but raises that extend from a caved drift in its footwall on the Mountain Spring level suggest some mineralization between the two levels. About 70 feet of the fault vein, showing a maximum thickness of 2 feet, was stoped for its zinc-lead content in the arkose below the A bed.

About 500 feet farther at $20,225 \mathrm{~N}, 17,620 \mathrm{E}$ (pl. $2 C)$, the Mountain Spring tunnel crosses, in strata about 90 feet below the $\mathrm{A}$ bed, a small fault along which most of the limestones of the middle Hermosa were richly mineralized. This fault is also virtually parallel to the Blackhawk fault, occurring 900 feet northeast of it on the Mountain Spring level as measured perpendicular to the fault strike. It dips irregularly $\left(55^{\circ}-90^{\circ}\right)$ toward the Blackhawk fault and drops the strata on that side. The displacement is about 15 feet on the A bed level, but it decreases to $6-8$ feet on the $\mathrm{E}$ bed level, and possibly to less at higher levels, though the fault is still a conspicuous break on the $J$ bed level. Transverse breaks of a comparable displacement are not mineralized. The strata dip gently in a northerly direction. Zonal placement of the zinc-lead ore bodies on the border between unaltered limestone and a comparatively barren pyritic core centered on the fault is conspicuous on the A, D, and E (Wellington) levels; it is less so on the $\mathrm{C}$ level because the pyritic core was well, though irregularly, mineralized by sphalerite and galena. The $\mathrm{H}$ level shows a partial barren core, but here, also, considerable ore has been found in the pyrite. On the I, J, and $\mathrm{K}$ levels, which are not so extensive as most of the lower ones, the ore was mined from runs on the southwest side of a pyritic body centered on the fault, but no ore was mined from the opposite side of the pyrite on the upthrown side of the fault. The Princeton fault bounds the southeast edges of the stopes on the D, E, I, and J levels and must be very close to the stope edges on the $\mathrm{C}$ and $\mathrm{H}$ levels. On the $\mathrm{L}$ bed level, surficial weathering beneath the thick landslide mass of $\mathrm{CHC}$ Hill, augmented by proximity to the Princeton fault, has converted much of the ore-bed limestone to a red clay.

\section{PIGEON TUNNEL}

The Pigeon portal is 1,800 feet north of the Mountain Spring portal at an altitude of 9,320 feet. The tunnel enters the hill at the base of the large outcrop island in the landslide area of $\mathrm{CHC}$ Hill, on the footwall side of the Blackhawk fault. Where the fault is crossed, 660 feet from the portal ( $p l .2 C$ ), the fault vein is about 40 feet thick. Immediately after crossing the fault, the tunnel swings right at an obtuse angle and stays in the hanging wall close to the fault, following an irregularly meandering course for about 1,200 feet. Near the middle of this stretch, the tunnel swings across the fault for a short distance, and then back, though a crosscut probes the footwall an additional 65 feet. The fault vein is here only 3 feet thick. At the breast of the Pigon tunnel the Pigeon raise connects through to the Mountain Spring level.

The A bed is exposed on the surface just south of the Pigeon portal, and appears in the roof of the tunnel, 120 feet in, but for the most part the tunnel crosscuts in sandstones and shales of the lower Hermosa until the Blackhawk fault is reached. After penetrating the fault vein and turning into the hanging wall of the fault, the tunnel traverses 110 feet from this turn to the point where the $\mathrm{H}$ bed limestone first appears above the floor, dipping $12^{\circ} \mathrm{WNW}$. The I bed is present at the top of a 97foot raise at the turn, which is only 15 feet from the edge of the Blackhawk vein at tunnel level. The structure farther back in the tunnel is complicated by numerous small faults and changes of dip, and the $\mathrm{H}$ bed appears again in the neighborhood of the crosscut into the footwall. No other limestone beds are exposed in the workings. Mineralization has been minimal at tunnel level, and there are few indications of ore derived from other levels; but small stopes off the Pigeon raise to the Mountain Spring level contained some tetrahedrite in the ore.

\section{ST. LOUIS TUNNEL}

The St. Louis tunnel was driven by the St. Louis Smelting \& Refining Co. during 1930-31 to explore for deep ore horizons below CHC Hill. The portal is at an altitude of 8,844 feet, on the east bank of the Dolores River, 1 mile upstream from Rico. The tunnel runs N. $70^{\circ} 33^{\prime} \mathrm{E}$. for a distance of 5,160 feet. At 4,531 feet the Blackhawk fault vein was crossed, and 50-65 feet beyond it, long crosscuts were turned in both directions in the hanging wall of the fault (pl. $2 C$ ).

The crosscut to the northwest runs 2,920 feet, though by the year 1955 it had caved at 1,445 feet at the Mountain Spring raise to the Mountain Spring 
level. The end stretch of this crosscut crossed from the northeast to the southwest side of the Pigeon tunnel near its breast, though a few hundred feet below the Pigeon tunnel. The crosscut stayed within 140 feet of the projected position of the Blackhawk fault as far as the Mountain Spring raise and is believed to have crossed into the footwall of the fault at 1,900 feet (St. Louis Smelting \& Refining Co., unpub. map).

The crosscut to the southeast was driven only a short distance beyond the Princeton fault by the St. Louis Smelting \& Refining Co., but was extended in the 1950's by the Rico Argentine Mining Co. to their workings on Silver Creek. It crosses the Princeton fault at 403 feet from the St. Louis tunnel. At 1,450 feet it crosses the Blackhawk fault at an acute angle and continues in the footwall of this fault to a point 390 feet northwest of the Argentine shaft where it crosses back into the hanging wall (pl. $3 G$ ). The total distance along the drift from the St. Louis tunnel to the Argentine shaft (as projected) is about 4,450 feet. The crosscut shows only minor deviations from a straight line and is believed to be within $\mathbf{1 1 0}$ feet of the Blackhawk fault throughout its length.

The strata traversed by the St. Louis tunnel from its portal are lower Hermosa sandstones and shales that dip gently to the south-southwest. The tendency for lower strata to rise into the tunnel as it penetrates in an east-northeast direction into the hill is offset by a series of small- to moderate-sized transcurrent faults that repeatedly drop the strata on the breastward side by approximately the amount of structural rise. Hence, only a limited stratigraphic section is exposed, apparently below the middle of the lower Hermosa. A sill of the hornblende latite porphyry is intercalated in the strata, its base dropping slightly in the section to the northeastward in a series of small steps. Thickness of this sill is hard to estimate, considering the low dip and irregularities in boundaries; but a rough calculation at one place suggests about 80 feet, and it may locally exceed 100 feet, though the last exposures to the northeast in the tunnel before disappearance into the roof suggest a thinning in that direction. About 195 feet before the Blackhawk fault is reached, the tunnel crosses an irregular dike of alaskite porphyry 25 feet thick, which dips nearly vertically (pl. $2 C$ ).

The Blackhawk fault has a displacement of about 200 feet where the St. Louis tunnel crosses it. The strata in the hanging wall are somewhat higher in the lower Hermosa, and include, in addition to the dominant sandstone and shale, a little shaly lime- stone and a 15-foot bed of dolomite. Along the line of the tunnel, the strata, which have changed to a gentle northeasterly dip here, are broken by at least nine moderately sized faults of undertermined throw, which strike parallel to the Blackhawk fault but dip in the opposite direction. These faults doubtless have normal displacement, and thus they offset the effect of the stratigraphic dip just as do the faults in the front part of the tunnel, but in the reverse direction.

The long crosscut southeast to the Rico Argentine mine crosses the Princeton fault into dominantly greenish sandstones and arkoses and some shales, dipping $25^{\circ} \mathrm{NW}$. but flattening within a few hundred feet, and believed to belong to the Rico Formation. Farther southeast, just before the Blackhawk fault is reached, a 30-foot dike of alaskite porphyry occurring in the immediate hanging wall of this fault may be a southeastward continuation of the previously mentioned dike. In the footwall of the fault, the crosscut enters northwest- to northward-dipping upper Hermosa strata that are about 640 feet above the base of this division. These strata are, of course, in the hanging wall of the Princeton fault. The rest of the crosscut traverses downward through the upper Hermosa section, reaching the top of the middle Hermosa in ground that is part of the Rico Argentine mine.

The exploration of the Leadville-Ouray Limestones for which the St. Louis tunnel was initially planned was unsuccessful. Although a little ore was taken here and there from pyritic beds in the lower Hermosa that were intersected in the extensive tunneling on the hanging-wall side of the Blackhawk fault, the lower Hermosa proved to be thicker under CHC Hill than anticipated, and diamond drilling in depth in the vicinity of the fault failed to reach the limestones of the Mississippian and Devonian. Drill hole 1 that was put down vertically from a station 120 feet in the footwall (portalward) of the Blackhawk fault (pl. $2 C$ ) went 430 feet in sandstone, shale, pyrite, and "porphyry." The last is evidently a 120 -foot sill in the lower Hermosa, intersected at depths of 126-246 feet. The pyrite, intersected at several levels in thicknesses of as much as 18 feet of varying proportions of pyrite, may, in part, represent replaced limestone or dolomite beds in the lower Hermosa, though some of the zones containing only $15-25$ percent pyrite are indicated as in sandstone or shale. Drill hole 3 that was put down vertically from a station 310 feet in the hanging wall of the fault penetrated 761 feet of sandstone, shale, porphyry, and some limestone and gypsum; 
the gypsum was below 600 feet. The porphyry here is at two levels, a 112-foot intercept at 184-296 feet and another 112-foot intercept at 630-742 feet, the later, however, containing a 9-foot sandstone parting.

If the two porphyry intercepts in hole 3 represent sills, the upper could well be the one that shows on the other side of the Blackhawk fault in the St. Louis tunnel, rising and disappearing into the roof as the fault is approached from the southwest. The interesting possibility is also raised that this upper sill could be the same as the one intersected at 126246 feet in hole 1 on the other side of the fault. If so, the major structural displacement on the Blackhawk fault zone here comes not on the quartz vein that almost universally marks the fault, but on the alaskite porphyry dike that, along the line of the tunnel, lies 195 feet in the footwall of the quartz vein and 80 feet portalward from drill hole 1 . Intrusion of the alaskite is believed to be late in the geologic history of the district, and most of the displacement on the Blackhawk fault may have preceded it. Evidence tending to support the surmise that the displacement occurs on the dike is the failure of drill hole 2 to intersect the porphyry above the tunnel level. This hole was put up 90 feet at an angle of $61^{\circ}$ (as projected) in the same block as hole 1 , between the alaskite porphyry dike and the Blackhawk fault (pl. 2C).

The lower porphyry intercepted in hole 3 , if a sill, might well be the attenuated extension of the Newman Hill sill, for a rough calculation, taking into account the thickness of lower Hermosa indicated in Newman Hill, suggests that about 250 feet of lower Hermosa strata should lie below the lower sill.

\section{RICO ARGENTINE GROUP}

The workings that constitute the Rico Argentine group of mines are on Silver Creek, about 1.5 miles northeast of Rico. Most of the surface openings are on the southeast side of the creek, but two shafts are on the northwest bank- the Argentine shaft and the 517 shaft which was raised in 1961-64 from St. Louis level to intersect a short entry tunnel from the surface. The main openings on the southeast side of the creek are tunnels and include, from the creek upward, the James G. Blaine tunnel, which is practically at creek level, the Rico Consolidated middle and upper tunnels, the Argentine tunnel, and the Log Cabin (Blackhawk) tunnel. The Rico Consolidated tunnels are caved at the portal but were accessible in the 1950's through extensions from the Argentine tunnel. Several tunnels higher than the Log Cabin have been long caved at their portals, though the Smith tunnel was accessible in 1957 through the Log Cabin workings.

Most of the ore taken from the Rico Argentine workings in recent years has come from levels below the Blaine tunnel. These are at irregular intervals, 67-140 feet, from the 200 to 600 levels, and undoubtedly lower levels will be established with further development. Although the Argentine shaft goes to the 300 level, it has been unusable for many years. The ore at an intermediate stage was taken out through an interior shaft (No. 3) from the Blaine level, or through the long St. Louis tunnel crosscut which comes in on the 500 level. As the St. Louis tunnel exit required an underground haul of 9,000 feet, and a surface haul of about the same to bring it back to the mill near where it was mined, the company drove the new shaft on the northwest side of the creek. The St. Louis crosscut serves a very useful purpose in providing gravity drainage for all workings on, or above, the 500 level.

The numerous workings of the mine group exploit the sulfide replacement deposits in the limestones of the middle Hermosa and in two of the lower limestone beds of the upper Hermosa in the vicinity of the Blackhawk fault. Both sides of the fault have been mineralized, but, as much of the favorable ground on the footwall side has been eroded, most of the workings to date have been in the hanging wall. All the limestone units of the middle Hermosa have been cut at some place or other, though some of the beds, in particular the A and B beds, have not as yet been productive. Except for local deviations in the vicinity of faults, the strata dip northeast at angles of $30^{\circ}-60^{\circ}$, averaging perhaps $40^{\circ}$. Mining has been complicated by numerous faults, some of which are regular enough to be projected between levels, whereas others are of local significance.

The structural features that localize the stopes are generally obscure. Where the ore follows very closely the intersection of the limestone bed with the Blackhawk fault, the shattering adjacent to the fault was obviously responsible. However, some of the ore bodies extend 200-300 feet from the fault. The stopes commonly run diagonally down the dip of the bedding. In some places, bedding slip faults can be identified along, or just above, the ore bed, and the attendant shattering in the limestone was doubtless the determinant. In other places, faults of small displacement can be recognized in the roofs of stopes, and such faults broke the susceptible host rock and acted as feeders for the ore solutions.

LOG CABIN (BLACKHAWK) TUNNEL

The Log Cabin tunnel enters the hill at about 
altitude 9,742 feet and bears generally east-southeast, nearly parallel to the strikes of the Blackhawk fault and of the strata. Its portal is 25 feet within the hanging wall of the Blackhawk fault just southeast of the Last Chance fault junction, and the entry tunnel merges onto the fault 250 feet from the portal. The mineralized ground is in the hanging wall to the northeast. At 340 feet from the portal, the main tunnel crosscuts over to the northeast to follow the Alleghany fissure, which is parallel to and about 200 feet from the Blackhawk fault; but farther along the tunnel, a branch crosscuts back to the Blackhawk fault and drifts along a small break in its immediate hanging wall ( $\mathrm{pl} .3 A$ ). Maximum penetration of the Log Cabin tunnel is about 1,400 feet into the hill.

The limestone beds mineralized include the $\mathrm{H}$, I-J, K, and L beds at the top of the middle Hermosa. The distribution of the beds at the Log Cabin level is shown on plate $3 A$. Most of the stopes at and above the Log Cabin level are between the Alleghany and Blackhawk breaks and within 210 feet of the latter, but those on the H and I-J beds follow eastward diagonally down the bedding to the Argentine level. As the Blackhawk fault also dips in this direction, though at a steeper angle, the distance between the fault and the outer edges of mineralized ground does not greatly increase. In a part of the ground, the stopes in the four ore beds are roughly superposed, indicating a common feeder system among the cross fractures. No single fracture can be mapped to account for this, but a system of connecting fissures are present. The ore solutions were thus able to travel from one to the other in a general zone of fracturing. The stope in the $\mathrm{H}$ bed, extending from below the Argentine level at the bottom to above the Log Cabin level at the top, is 420 feet long and a maximum of 60 feet wide, as projected on a horizontal plane. The stope in the I-J bed bottoms at the Argentine level and extends up through the Log Cabin level to somewhat above the Carbonate tunnel whose caved portal is 109 feet above the Log Cabin portal. This stope (as projected) is 580 feet long and a maximum of 150 feet wide, though averaging $60-80$ feet. The stope in the $\mathrm{K}$ bed, which is thin, bottoms between the Argentine and Log Cabin levels and extends through the Log Cabin level to some distance above the Smith tunnel, breaking through to the surface at its upper end. It has a projected length of 500 feet and a width that is generally less than 40 feet, but attains 90 feet at the upper end. A persistent bedding fault at the top of the $\mathrm{K}$ bed may have furnished the structural setting for the mineralization.
In the $\mathrm{L}$ bed, part of the stoping is superposed on that in the lower beds, but there is extensive stoping which is independent of that in lower beds. None of the stopes in the $\mathrm{L}$ bed extend below the Log Cabin level. The largest stope, superposed at the west end and running more nearly parallel to the strike of the bedding, is 580 feet long and maximum 120 feet wide.

The Alleghany fissure, so conspicuous on the map of the Log Cabin level (pl. $3 A$ ), may have been a mineralizing fissure for all the traversed beds $(\mathrm{H}$ to $L)$ adjacent to its northwest extent along the level, but it failed to mineralize the $\mathrm{L}$ bed for a long stretch near the southeast end of the level. The fissure is a fault of reverse throw and small displacement. It dips mostly southwest at $60^{\circ}-80^{\circ}$, with the southwest side up 5-18 feet as measured on the level. The fissure contains $2-8$ inches of gouge, pyrite, calcite, and, locally, some sphalerite.

\section{BLACKSMITH TUNNEL}

Although the Blacksmith tunnel has not been accessible during the fieldwork for the present report, it is of special interest because of the stratigraphic units involved in the mineralization. The tunnel portal is S. $56^{\circ}$ E., 530 feet from the Log Cabin portal, and about 267 feet higher. As interpreted from cross section and stope maps prepared by W. R. Landwehr, geologist of the American Smelting \& Refining Co., the tunnel provided access to stopes in the two lowest limestone beds of the upper Hermosa within 200 feet of the Blackhawk fault. The stratigraphic units mineralized are Nos. 27 and 29 of the composite section (see p. 24), whose bases are about 126 and 202 feet, respectively, above the base of the upper Hermosa. The lower stope trends nearly parallel to the strike of the bedding and is 185 feet long and 40 feet wide maximum. The upper one, which is really two closely juxtaposed stopes of very irregular outline, shows an overall projected length of nearly 200 feet down the dip of the bedding starting from the Blackhawk fault and a maximum width of 120 feet. These stopes are not superposed, nor do they overlie stopes in limestones of the middle Hermosa. Lower limestone strata at the top of the middle Hermosa are pinched out against the fault below the level of the Blacksmith tunnel.

\section{ARGENTINE TUNNEL}

The Argentine tunnel is in the hanging-wall block of the Blackhawk fault northeast of the Log Cabin tunnel and about 160 feet lower, its portal having an altitude of about 9,588 feet. It trends in a general southeasterly direction nearly parallel to the strike of the bedding and shows an overall penetration of 
about 2,400 feet into the hill. In the first 930 feet are several prongs that are more or less interconnecting, but beyond that, the working is a linear tunnel from which a few crosscuts have been extended (pl. 3B).

Some of the prongs of the tunnel in the first 930 feet intersect the lower ends of two of the large stopes previously discussed for the Log Cabin level, namely, those in the $\mathrm{H}$ and I-J beds. At their lower ends the outer edges of these stopes are, respectively, 160 and 220 feet from the Blackhawk fault, as measured on the level. Much of the ore from stoping in the $\mathrm{K}$ bed between the Argentine and Log Cabin levels was also taken out through these prongs of the tunnel. The Argentine workings in this block also intersect mineralized ground in a lower bed, the $\mathrm{E}$ bed, which pinches out against the Blackhawk fault well below the Log Cabin level. The stoped ground in the $\mathrm{E}$ bed is small and is characterized by an abundance of garnet. Plate $3 B$ shows the distribution of the limestone beds on the Argentine level.

The Blackhawk fault has been probed by crosscuts at four places (pl. $3 B$ ), but no workings penetrate more than 40 feet into the lower Hermosa strata of the footwall.

The other dominant structure revealed on the tunnel level is the Honduras fault, which is a reverse fault trending slightly south of east and dropping the strata on the north side about 140 feet. Although the displacement is in the same direction as that of the Blackhawk fault, the dip is in the opposite direction, mostly $70^{\circ}-80^{\circ} \mathrm{S}$. The fault break is occupied by 2-8 feet but commonly about 5 feet of gouge, quartz, and pyrite. The I-J bed limestone unit in the dropped block has been mineralized and stoped at a level between the Argentine and underlying Blaine level. This " 4 bed" stope, ${ }^{7}$ though irregular in shape, is about 250 feet long in a direction nearly perpendicular to the fault and 90 feet wide at the maximum. However, another prong of the stope 10-20 feet wide follows along the north side of the fault for a distance of 140 feet west from the main stope. Mineralization of this latter prong can be attributed to shattering along the hanging-wall side of the Honduras fault. The main northwardtrending prong lies along the northwest side of the Rico Argentine dike; shattering of the limestone adjacent to the dike probably furnished the channelways for introduction of the ore solutions. However, the northern part of the stope is also traversed by a small fault dipping westward at

\footnotetext{
"The stope is labeled " 4 bed" stope on mining company maps, but this is a misidentification, as it is really in the 2 bed of company terminology; see the composite section, p. 24 .
}

$45^{\circ}-60^{\circ}$ and dropping the strata on the west about 15 feet. Updip and a little farther north this fault was responsible for a replacement blanket of sulfide ore at a higher stratigraphic level in the middle tunnel of the Rico Consolidated mine (see p. 84). The remote end of the " 4 bed" stope is about 450 feet from the Blackhawk fault. The stope is of mineralogic interest in that cosalite and huebnerite, rare minerals for the district, are present in the massive pyritic replacement ore.

In the ground explored by the deeper parts of the Argentine tunnel, mineralization was not so extensive as in the first 930 feet. The deeper part of the tunnel follows the general course of the Alleghany fissure. Over much of the Argentine level this fissure is 60-120 feet northeast of the Blackhawk fault, striking nearly parallel to it but dipping generally in the opposite direction (southwest) at $60^{\circ}-80^{\circ}$, except near the southeast end of the mine where it steepens through verticality and farther southeast dips parallel to the Blackhawk fault. Displacement on this level amounts to a few tens of feet, down on the northeast. Although the northwest end of the Alleghany fissure was apparently an important part of the feeder system for the mineralization in the front part of the mine, it was a less effective mineralizer farther southeast. Nevertheless, there are some stopes that are obviously related to it. Where it intersects the I-J bed above the Argentine level in the 3-compartment raise to the Log Cabin level, at $14,060 \mathrm{~N}, 14,690 \mathrm{E}$ (pl. $3 B$ ), a stope extends southeast for at least 180 feet. The stope is about 10 feet wide, and narrowly confined to the intersection of the fissure with the ore bed which here strikes nearly parallel to the fissure and dips about $45^{\circ} \mathrm{NE}$. This stope is about 150 feet from the Blackhawk fault.

At 250 feet from the southeast end of the tunnel where the Alleghany fissure dips northeast, its hanging wall contains the 138 stope which is a pyritic copper stope in the $\mathrm{L}$ bed, running eastward diagonally down the dip of the bedding to the Blaine level. Owing to the gradual convergence of the Alleghany fissure and Blackhawk fault at this end of the mine, the 138 stope is also only a short distance in the hanging wall of the Blackhawk fault, 60 feet from the fault at the Argentine level and 120 feet from the fault at the Blaine level. The stope is 300 feet long as projected on a horizontal plane and a maximum of 70 feet wide. Slickensides in the stope indicate that faulting along the bedding was an important structural preliminary to the mineralization. The stope is reported to have yielded 2 ounces of silver for each percent of copper. 
A crosscut to the northeast near the end of the Argentine tunnel intersects a bedding fault near and at the top of the $\mathrm{L}$ bed. There has been some stoping of this bed on and below the fault and updip from the level, but the amount of ore obtained was not great. The mineralized segment of the ore bed is bounded laterally by crosscutting porphyry dikes, one of which was offset by the bedding fault. Stoped ground in this block is a maximum of 250 feet from the Blackhawk fault.

\section{RICO CONSOLIDATED TUNNELS}

The three tunnels of the Rico Consolidated mine are about 400 feet northeast of the Argentine portal. The altitude of the upper tunnel portal is 9,629 feet, and of the middle portal, about 9,563 feet. Both portals are caved; but the middle tunnel is accessible from the Argentine workings, and the upper tunnel is accessible from the middle tunnel. The lower tunnel is caved.

The tunnels enter the hill in an irregular, but generally, south-southeasterly direction. The middle tunnel at about 600 feet from the portal hits the Honduras fault and drifts east on it for 250 feet (pl. $3 B$ ). The strata traversed are chiefly the basal part of the upper Hermosa. However, the L bed, at the top of the middle Hermosa, is intersected 80 feet before the Honduras fault is reached and is also cut on the south side of the Honduras fault in the drift to the east. It is not mineralized.

The only mineralized ground is in the front part of the mine, in the lowest good limestone bed of the upper Hermosa, unit 27 of the composite section (see p. 24). Most of the mineralization is adjacent to the 210 Drift fault near its northeast end, and chiefly on its south or upthrown side. In contrast to its general vertical attitude elsewhere, the fault here dips $70^{\circ} \mathrm{S}$., and hence shows reverse displacement amounting to about 20 feet. A large stope $20-30$ feet wide plunges eastward diagonally down the dip of the bed at its intersection with the fault, and a pyritized blanket of the ore bed about 100 feet wide extends south from the fault diagonally up the bedding dip and nearly perpendicular to the fault. This pyrite blanket is traversed lengthwise by the small cross fault, dipping $46^{\circ}-60^{\circ}$ W., that is followed for several hundred feet by the main tunnel. The fault drops the strata on the west about 17 feet and also displaces the Rico Argentine dike (pl. $3 B$ ). It is undoubtedly the feeder for the sulfide mineralization in the pyritic blanket. The center of this blanket is too low grade to be minable, but ore stopes were developed along its two sides. The larger stope on the east side is about 160 feet long as projected on a horizontal plane and is $\mathbf{1 5 - 2 0}$ feet wide. A bedding fault at the top of the ore bed doubtless facilitated the introduction of the ore solutions. The presence of hydrated iron oxides and green copper stains in the walls of the stopes suggests that the ore taken out was partly oxidized.

An additional small stope was opened along the northwest side of the Rico Argentine porphyry dike. This stope was not completely mapped, so its length is not available. It has a maximum width of 20 feet but is for the most part only 6 or 7 feet wide.

The upper tunnel explores the ore bed at a higher level where it is massively pyritized, but there was only negligible stoping on this level, along the edge of the porphyry dike. The tunnel crosses the vertical Honduras fault at 590 feet from its portal and extends 155 feet farther into the footwall.

The stopes on the middle tunnel level are $600-800$ feet from the Blackhawk fault and 260-460 feet from the Honduras fault. It appears obvious that the 210 Drift fault, which in most places is a tight poorly mineralized fissure, has acted as a mineralizing channel in this place, though the eventual trunk channel may well have been the Blackhawk fault.

\section{JAMES G. BLAINE TUNNEL}

The Blaine tunnel enters the southeast bank of Silver Creek just above creek level at an altitude of about 9,336 feet, 400 feet east of the Rico Argentine mill. It starts on the southwest side of the Blackhawk fault in the thick shale unit just above the $\mathrm{H}$ bed of the middle Hermosa and follows a general east-southeast course until it intersects the Blackhawk fault, 410 feet from the portal. From here, the course is southeast along the Blackhawk fault, though the fault is not followed in detail (pl. $3 C$ ). In the first 1,700 feet from the portal there is, in addition to the main haulage tunnel, an intricate system of drifts, crosscuts, and stopes that develop the blocks of ground on both sides of the fault, but particularly the northeast, or hanging-wall, side. Beyond 1,700 feet from the portal (measured in a straight line), the chief working is the main haulage tunnel, but numerous tributary crosscuts explore adjacent ground. The total straight-line length of the tunnel is 3,750 feet, though the actual length is somewhat greater because of deviations in course. In the last 1,250 feet, the main tunnel diverges from the Blackhawk fault into its hanging wall, though crosscuts to the fault indicate that the tunnel is nowhere more than 125 feet northeast from the fault.

The structure in the front 1,700 feet of the Blaine workings is greatly complicated by the junction of the Honduras and Blackhawk faults on this level. Although both faults drop the strata on the north 
side, the Honduras is a reverse fault that dips opposite to, and merges with, the Blackhawk in depth. On the Argentine level where the two are somewhat farther apart, they are slightly divergent in strike, and the Honduras fault is a well-defined break of uniform trend. On the Blaine level, however, where the faults are closer together, each fault has apparently affected the course of the other and the two average nearly parallel in strike from their junction to as far east as the Honduras is exposed on the level. Thus, the two faults at 800 feet east of their junction are only 210-220 feet apart (pl. 3C). Furthermore, the Honduras fault has broken into several segments, some of which show curving trends and southward dips as low as $40^{\circ}$. The block between the two faults is further broken by other small faults and by porphyry dikes and sills that add to the complication. Correlation of the beds are correspondingly uncertain, as indicated by the queries on plate $3 C$.

The stope ("4 bed" stope) above the Blaine level in the I-J bed on the northwest side of the Rico Argentine dike and north of the Honduras fault was mentioned in the discussion of the Argentine tunnel. Most of this ore was taken out through the Blaine tunnel. A stope similar in position but narrower ("upper Con" and "lower Con" stope) was developed in the $\mathrm{H}$ bed on the southeast side of the dike, running on an incline nearly parallel to the dip of the bedding from above the Blaine level to below the 200 level. Some faulting shows along the dike wall. This stope is generally 5-20 feet, though locally 50 feet, wide and more than 300 feet long as projected on a horizontal plane. Its height of 40 60 feet in places suggests that some of the clastic strata above the $\mathrm{H}$ bed may have been shattered and mineralized. It connects at the bottom with another stope that extends to the 300 level. At its upper end it is close to the Honduras fault, though the breakup of the fault into several segments here makes the exact position of the fault indefinite. The upper end of the stope is about 200 feet from the Blackhawk fault.

Several stopes in the narrow block of ground between the Honduras and Blackhawk faults were only partly accessible during the fieldwork for the present report. They were developed in the $\mathrm{C}, \mathrm{D}$, $\mathrm{E}$, and $\mathrm{H}$ beds and are only in part superposed. Although these stopes do not extend up to the Argentine level, they are in the same general block of ground that contains the major stopes of that level, indicating that the hanging wall of the Blackhawk fault near its junction with the Honduras fault was a major locus for ore deposition.
The back part of the Blaine level beyond 1,700 feet from the portal does not contain ore stopes commensurate to the amount of development work done in exploration. Perhaps this is due in part to the abundance of porphyry, a generally unfavorable host rock for ore, in thick dikes and sills in the most favorable ground adjacent to the Blackhawk fault. The Alleghany fissure, which follows the Argentine level overlying this stretch of the Blaine tunnel, joins the Blackhawk fault above the Blaine level, except at its southeast end where the reversal of dip visible on the Argentine level may have extended a segment of the fissure to the Blaine level (pl. $3 C$ ). Two other fissures northeast of this possible Alleghany remnant and dipping northeast have mineralized, respectively, the I-J bed on the south side of the main haulage tunnel east of the long crosscut to the south and the $\mathrm{K}$ bed in a narrow stope above the haulage level. Both stopes are within 110 feet of the Blackhawk fault but are relatively small. The 138 stope, in the L bed southwest of the tunnel, is a large stope in the hanging wall of the Alleghany fissure, already mentioned in the discussion of the Argentine level.

In the front part of the Blaine tunnel, the hanging wall of the Blackhawk fault northwest of the Honduras fault junction contains several relatively small stopes in the immediate vicinity of the Blackhawk fault. These stopes were worked partly in winzes below the level. South of the 210 Drift fault, they are in the $\mathrm{C}$ and $\mathrm{D}$ beds; north of this fault, which drops the strata on the north about 265 feet at the Blackhawk fault junction, the only significant stope in the hanging wall is in the Morris Cook inclined winze in the $\mathrm{K}$ bed. This stope, which is about 20 feet wide and extends for about 180 feet from the Blackhawk fault diagonally down the dip of the bedding, is just below a porphyry sill whose base may have been somewhat mineralized.

The vein on the Blackhawk fault above the level was stoped between sandstone walls for about 150 feet southeast from where the entry adit first hits the fault.

In contrast to the relations on the Argentine and higher levels, the Blackhawk fault in the front part of the Blaine tunnel has only the moderate displacement that prevails north of the junction with the Last Chance fault- 43 feet just north of the 210 Drift fault junction. Hence, the middle Hermosa strata, though somewhat uplifted, have been only partly eroded from the southwest or footwall side of the fault. Several of the limestone beds here contained important ore bodies. The 102 drift traverses a complexly faulted block southwest of the 
Blackhawk fault. At its beginning, it drifts on a conspicuous steeply north-dipping vein which, at first impression, appears to represent the southwestward continuation of the 210 Drift fault of the Blackhawk hanging wall, offset 50 feet to the southeast by that fault. However, the vein is truncated within 160 feet by a lower dipping fault, and other fault veins, mostly dipping north at $43^{\circ}-60^{\circ}$, are crossed by the 102 drift within a short distance (pl. $3 C)$. Furthermore, exposures on the 200 and 300 levels fail to show any fault break on the southwest side of the Blackhawk having a throw comparable to that of the 210 Drift fault. Hence, the concept of a simple earlier fault having considerable throw, crossed and offset by the Blackhawk fault, is untenable. However, there may have been an originally continuous break whose displacement was greatly augmented on the northeast side when the Blackhawk fault was formed. The faults crossed by the 102 drift and its branches are of small displacement, but they produced several ore bodies at their intersections with limestone beds. Because of the complexities produced by the faulting, the ore beds are not all satisfactorily identified, though some ore bodies are definitely in the $\mathrm{E}$ bed, and others are probably in the $\mathrm{H}$ bed. Most of the stopes are relatively small, and narrowly confined to the faults. Some, not now accessible, may actually be on the veins in clastic strata. At the end of the drift, however, a huge stope was opened in the E bed. Only a small upper part of this stope is above the Blaine level, but it is practically continuous downdip to the 300 level. Most of the ore was removed through the 200 and 300 levels. Between these levels the stope is in contact with the Blackhawk fault, but its upper end is 470 feet from the fault as measured on the Blaine level.

The only other large stope in the footwall of the Blackhawk fault on the Blaine level is north of the entry tunnel from the portal. This stope is in the I-J bed, extending from the intersection of this bed with the fault out to a maximum of 40 feet from the fault in the ground above the Blaine level. The stope follows the dip down to below the 300 level and is much wider at the 200 level.

The footwall of the Blackhawk fault southeast of the junction with the Last Chance fault has been explored by crosscuts at several places. These crosscuts have penetrated lower Hermosa sandstones and shales containing a large proportion of porphyry in dikes and sills. The longest crosscut to the south is 700 feet. The last 500 feet of this is in porphyry that appears to be a thick sill whose upfaulted base is visible a few feet above the floor of the crosscut near and at the end. The sill contains at one place a narrow horse of shale and sandstone which has nearly vertical sides and is traversed by a small fault. This sill may be the underground extension of the Newman Hill sill (see p. 34).

\section{LEVEL}

The 200 level is 100 feet below the Blaine tunnel level at the No. 3 shaft. It is the highest level below the bed of Silver Creek and was originally opened from the Argentine shaft. Later, the level was worked through the No. 3 shaft whose collar is on the Blaine level, but it is now worked through the 517 shaft driven in the 1960's.

The main haulage tunnel for the level follows the Blackhawk fault fairly closely for about 650 feet from the Argentine shaft southeast to 100 feet beyond the junction with the 210 Drift fault (pl. $3 D$ ). Here, the tunnel turns more east-southeastward into the hanging wall of the Blackhawk fault and extends 1,500 feet farther in a fairly direct line. Where the tunnel is along the Blackhawk fault, drifts into the footwall explore and develop several ore deposits, and two crosscuts explore barren ground in the hanging wall. Workings tributary to the tunnel after the turn to the east include a major crosscut (214) for 520 feet to the northeast along the Rico Argentine dike, and three exploratory crosscuts to the south, two of which reach the Blackhawk fault.

Distribution of the limestone beds on the 200 level is shown on plate $3 D$. Major ore deposits were stoped in the footwall of the Blackhawk fault, in part from the 200 level. The two largest of these in the $\mathrm{E}$ and I-J beds, apexing above the Blaine level and bottoming on or below the 300 level, have been previously mentioned. The stope in the $\mathrm{E}$ bed is in contact with the fault between the 300 and 200 levels. Much of the stope in this interval was not accessible for examination; part of it is only 30 feet wide, but locally its outer edge extends to 200 feet from the fault. Above the 200 level the stope extends away from the fault, generally west diagonally up the intersection of the $\mathrm{E}$ bed with one or more of the footwall faults mentioned in the discussion of the Blaine level. That part of the stope above the 200 level is somewhat curving, 500 feet long as projected on a horizontal plane, and 20-50 feet wide, though containing some barren blocks that have been left as pillars. A smaller stope in the same block, occurring to the north but connected with the big one at both ends, is developed in the $\mathrm{E}$ bed just above a somewhat crosscutting porphyry sill. This stope is 280 feet long, 6-25 feet wide, and 5-15 feet 
high. At least some of the ore in it was contained in the highly altered porphyry.

Mineralization in the $\mathrm{H}$ bed on the footwall side of the Blackhawk fault was limited to a narrow tabular ore body parallel to the fault. The stope is mostly 6-8 feet wide but increases to 27 feet wide at the upper end, which is well below the Blaine level. A stope height of 40 feet indicates that the complete thickness of the bed was mineralized. At the upper end of the stope, a porphyry dike 5-8 feet thick between the Blackhawk fault and the mineralized limestone shows some slickensiding parallel to the fault.

The stope in the I-J bed apexes above the Blaine level and bottoms against the Nellie Bly cross fault below the 300 level. It is a wide blanket stope bordering directly on the Blackhawk fault above the 200 level, but below that level a low-grade or barren pillar intervenes between the stope and fault over much of the stope length. Diagonally down the dip of the bedding the stope shows an overall length of about 560 feet as projected onto a horizontal plane, which is equivalent to a true length of 650 feet; the greatest width is 200 feet, at the 200 level. However, the stope is relatively thin, as the mineralization was confined to the top 5 or 6 feet of the limestone except near the fault above the 200 level where thicknesses to 20 feet are indicated by the configuration of the stope.

A narrow pipelike stope in the $\mathrm{K}$ bed borders the footwall side of the Blackhawk fault from the 200 to just below the 300 level, starting very near the Argentine shaft on the 200 level. The ore bed here has been broken and dragged down several feet along two small subsidiary faults, the closest only 6 feet from the main fault. The stoped ground is only 6-15 feet wide, and presumably not more than 5 or 6 feet thick, in conformity with the thinness of the $\mathrm{K}$ bed. Very little of the $\mathrm{K}$ bed remains in the ground below the 300 level updip from a segment of the Nellie Bly fault (fig. 2).

The $\mathrm{L}$ bed crops out on the surface just west of the Argentine shaft collar, but its downdip projection could be tested by extending the 200 level northwest along the Blackhawk fault. However, the potential ground in the $\mathrm{L}$ bed is limited downdip from the 200 level by the position of the Nellie Bly fault (pl. $3 E$ ) which cuts off the L bed above the 300 level and drops it on the north to a position between the 300 and 400 levels (where it has already been stoped).

The hanging-wall side of the Blackhawk fault is not as extensively mineralized adjacent to the 200 level as the footwall side. An irregular blanket stope in the $\mathrm{H}$ bed, no longer accessible, was apparently worked, in part at least, as a sump from the 200 level. This stope borders and extends out 100 feet from the fault. Another small stope is in the $\mathrm{C}$ bed below a somewhat crosscutting porphyry sill bordering the Blackhawk fault just south of the junction with the 210 Drift fault.

Several stopes border the Rico Argentine dike which strikes nearly perpendicular to the trend of the Blackhawk fault in its hanging wall several hundred feet east of the richly mineralized block in the footwall, previously described. The stope in the $\mathrm{H}$ bed on the southeast side of the dike was mentioned in the discussion of the Blaine level. On the northwest side of the dike, stopes have been developed in the $\mathrm{D}$ and $\mathrm{E}$ beds between the 200 and 300 levels, and some stoping was done in the dike in this interval and above the 200 level.

Very little of the Honduras fault has been cut on the 200 level. It lies at the north edge of the workings 200 feet east of the Rico Argentine dike (pl. $3 D$ ) where it dips southwest at $77^{\circ}-90^{\circ}$ and shows a displacement of about 150 feet, down on the north. At the crosscut east of the dike, the fault has evidently split into two segments that dip northeast at $83^{\circ}$ and $68^{\circ}$. Some warping of at least one of the segments is necessary to project the fault through a vertical 10 - to 18 -inch quartz vein that marks the best projection of the fault across the dike. The major displacement, however, appears to have veered southwest along the trend of the dike, corresponding to a similar change in direction of a major component on the Blaine level. As no longitudinal fault was recognized in the dike, this doubtless means that the dike was emplaced later than the main part of the Honduras faulting, a surmise also strengthened by the termination of the dike against the fault on the Argentine level.

Southeast of the Rico Argentine dike, the Honduras and Blackhawk faults are nearly parallel and are about 120-150 feet apart. Several ore deposits have been developed in the intervening block in the C, D, and $\mathrm{E}$ beds above the 200 level. A stope involving the $\mathrm{C}$ and $\mathrm{D}$ beds is continuous un to the Blaine level. The A and B beds were cut along the main haulage drift at the northwest end of this block, but they are not there mineralized.

\section{LEVEL}

The 300 level is 117 feet below the 200 level at the No. 3 shaft. The tunnel workings adjacent to the Blackhawk fault extend from 470 feet northwest of the Argentine shaft to 630 feet southeast of it, though only the last 500 feet of the latter stretch is actually on the fault. Farther southeast, the tun- 
nel swings into the hanging wall similarly to the 200 level and extends an additional 1,300 feet. It has major crosscuts to the north and northeast; the northeast crosscut is along the general course of the Rico Argentine dike. The main tunnel branches near its end, a north branch largely following the Honduras fault and a south branch crosscutting to the south and reaching at least a segment of the Blackhawk fault (pl. 3E).

Crosscuts into the footwall of the Blackhawk fault have been minimal, consisting for the most part of developmental workings to undercut the stopes but including also the haulageway to the $\mathbf{5 1 7}$ shaft. Major ore deposits in the E, I-J, and $\mathrm{K}$ beds have already been mentioned in the discussion of the 200 level. The Nellie Bly fault produces a stratigraphic gap on the 300 level that includes the $\mathrm{L}$ bed (fig. 2). At the north end of the level is a stope in the lowest limestone of the upper Hermosa (unit 27 of the composite section) at its intersection with the Blackhawk fault.

The immediate hanging wall of the Blackhawk fault southeast of the Argentine shaft contains a narrow tabular stope along a subsidiary fault of small displacement at its intersection with the $\mathrm{H}$ bed. The stope is $10-20$ feet wide perpendicular to the fault and extends nearly up to the 200 level.

Another hanging wall stope was developed in the $\mathrm{E}$ bed just north of the 210 Drift fault. The stope extends 110 feet out from the Blackhawk fault and in places is at least 20 feet thick. At its east side it is below a somewhat crosscutting porphyry sill. The updip margin is at the intersection of the ore bed with the 210 Drift fault, though in places the stope crosses this fault into unidentified strata south of it in the ground immediately adjacent to the Blackhawk fault.

Small stopes in the E bed in the first crosscut to the north, east of the No. 3 shaft, are of interest only in that they are as much as 390-460 feet from the Blackhawk fault. They are in the footwall of a small thrust fault.

Stopes along the northwest side of the Rico Argentine dike in the $\mathrm{D}$ and $\mathrm{E}$ beds were mentioned in the discussion of the 200 level. The one in the top 8 feet of the D bed extends as a winze somewhat below the 300 level where it is as much as 25 feet wide. Pipelike stopes are also present along both walls of the dike in the lower part of the $\mathrm{C}$ bed at its intersection with a $38^{\circ}$ fault, the one on the northwest side apparently rising steeply through the porphyry dike to the 200 level at the upper end. A narrow inclined pipe stope in the $\mathrm{C}$ bed is also de- veloped along the intersection of two small faults for $\mathbf{1 3 0}$ feet west from the dike.

A fairly narrow stope in the $\mathrm{H}$ bed along the southeast side of the dike extends from the 300 level up nearly, but not quite, to junction with the lower end of the extensive stope, in the same position, that extends from the 200 level to above the Blaine level. There is an additional pipe-like stope in the $\mathrm{H}$ bed which, at its lower end, somewhat below the 300 level, is 200 feet east of the dike but swings in upward and joins the stope along the dike at the 200 level. For most of this distance this latter stope is in the limestone along the top of a somewhat crosscutting porphyry sill. The stope is 9-25 feet wide and averages perhaps 15 feet high. In places, the porphyry was mineralized enough to have been stoped along with the replaced limestone. The lower end of this stope is about $\mathbf{5 0 0}$ feet from the Blackhawk fault.

The Honduras fault lies at an unknown distance within the southwest wall of the 300 level workings at the Rico Argentine dike intersection and is first cut by the main tunnel at a point 250 feet southeast of the dike. Here, it is perhaps 140 feet from the Blackhawk fault, but the two diverge somewhat farther southeast (pl. $3 E$ ). Some stoping of ore has taken place farther southeast, chiefly along, or adjacent to, the Honduras fault, but most of the stopes are no longer accessible. The complications produced by several obscure faults and igneous masses make correlation of the beds uncertain (pl. $3 E$ ), but the stopes are probably in the $\mathrm{A}, \mathrm{D}$, and $\mathrm{E}$ beds, and possibly in one or both of the intervening ones. Those stopes seen have been relatively small.

\section{LEVEL}

The 400 level is about 140 feet below the $\mathbf{3 0 0}$ level at the 517 shaft. The main haulage tunnel in the northwest half of the level is in the footwall of the Blackhawk fault, and explores the $\mathrm{E}$ to $\mathrm{L}$ beds adjacent to the fault over a fault length of $\mathbf{5 3 0}$ feet (pl. $3 F^{\prime}$ ). At the intersection with the $\mathrm{E}$ bed the fault has a displacement of about 35 feet, which is less than the thickness of the $\mathrm{E}$ bed. A part of the $\mathrm{E}$ bed extending for 30 feet from the fault on the 400 level has been stoped down to the 600 level, though this stope crosses to the $\mathrm{E}$ bed in the hanging wall of the fault somewhere above the 500 level. The $\mathrm{H}$ bed for 25 feet adjacent to the fault has been stoped updip nearly to the 300 level. The I-J and K beds are in the stratigraphic gap on the 400 level produced by the Nellie Bly fault (fig. 2), though the top of a $\mathrm{K}$ bed stope barely reaches the level. The north end of the level terminates at a stope about 10 feet wide 
in the L bed, whose upper few feet has been stoped downward to the 500 level and upward to the Nellie Bly fault. The $L$ bed has also been extensively stoped above the level, probably to above the 300 level, in the immediate hanging wall of the Blackhawk fault; there the stope is 10-20 feet wide.

The southeast half of the 400 level is in the hanging wall of the Blackhawk fault, and the tunnel (as of 1969) is almost entirely a drift, 650 feet long, in the E Bed. This bed contained several ore bodies updip from the level, and one of the largest stopes continues down to the 600 level. From the 400 to the 500 level, the ore was in two roughly parallel pipes with an intervening barren pillar, but the pipes coalesced at the 500 level and below this a single pipe was stoped down to the 600 level. Although this stope had not been surveyed at the time of the geologic examination, estimates were made of its dimensions above the 400 level. It crosses the 400 level about 110-120 feet from the Blackhawk fault, climbs up the dip of the bedding for an estimated 80 feet (as projected on a horizontal plane), and then swings more nearly parallel to the strike of the fault. In its upper part, it must be closer to the fault than at the level crossing, but the fault is nowhere cut. Over a length of 300 feet above the 400 level, the stope shows an average width of 15-20 feet and a height of 25-30 feet, except near the end where the height decreases to 15 feet. Smaller stopes in a more intricate pattern extend farther and eventually extend back east to the main drift at and near its end, 450 feet from the beginning of the stope. The control for the ore body is obscure, but this general area has been affected by bedding faults that are visible near the top of the $\mathrm{E}$ bed, and the 210 Drift fault must lie just south of the stoped ground (pl. $3 F$ ). At the crossing of the main level, the stope is on the axis of a shallow synclinal trough, though this structure cannot be extended very far up the stope.

\section{LEVEL}

The 500 level is the continuation of the long crosscut from the St. Louis tunnel into Rico Argentine ground but is worked through the 517 shaft. It is about 102 feet below the 400 level. The stratigraphic sequence on the level is complicated by several segments of the Nellie Bly fault (pl. $3 G$ ), most of which are so tight and obscure as to belie their considerable significance. The level develops both the foot and hanging walls of the Blackhawk fault.

In the footwall, the $\mathrm{E}$ and lower beds (down to the $\mathrm{B}$ bed) were not mineralized. Both the $\mathrm{H}$ and I-J beds were eliminated on or slightly above the level by segments of the Nellie Bly fault (pl. $3 G$ ). From the $\mathrm{K}$ bed, a replacement blanket of considerable extent was mined between the 600 and 400 levels. Although this ore bed was thinned even below its usual 4-5 feet thickness by a bedding fault (to which, however, the mineralization can be attributed), the ore blanket extended as much as $\mathbf{1 0 0}$ feet into the footwall of the Blackhawk fault and had a mining length above the 600 level of about 280 feet as measured on the ore bed (fig. 2). The $L$ bed in the footwall was mined in a narrower stope perhaps 25 feet wide adjacent to the fault and extending from the $\mathbf{5 0 0}$ level to well above the $\mathbf{4 0 0}$ level.

In the hanging wall, two pipelike stopes in the $\mathbf{E}$ bed, extending from the 600 through the 500 to, and one of them above, the 400 level, have been described under the 400 level heading. There was also a stope above the 500 level in the I-J bed. This stope bottomed on the northeasterly fault that may be related to the Nellie Bly system (see p. 46).

\section{LEVEL}

The 600 level, 67 feet below the 500, is developed by a drift 700 feet long which follows the Blackhawk fault except at its southeast end where it cuts into the hanging wall (pl. $3 H$ ). The workings explore the section from the $E$ to $L$ bed on both sides of the fault. In the hanging wall, ore was found in the two ore pipes in the $\mathrm{E}$ bed, already described in the discussion of the 400 level. In the footwall, stopes have been developed in the $\mathrm{H}$ (presumably), I-J, K, and $\mathrm{L}$ beds. Because of complications related to the Nellie Bly fault system, the $\mathrm{H}$ bed is not exposed in the footwall near the Blackhawk fault on the 600 level but is presumed to be the ore bed in a stoped block of ground between the 600 and 500 levels, though the stope was not accessible when the ground was examined in 1969. The other three ore beds have stopes that extend 80 feet ( $\mathrm{L}$ bed) to 100 feet (K and I-J beds) into the footwall on the level, and updip to or above the 500 level. The stope in the I-J bed is in the lower 5-8 feet of the limestone, whereas that in the $\mathrm{L}$ bed is in the top 7 feet.

\section{YELLOW JACKET (PHOENIX) GROUP}

The Yellow Jacket group of mine workings is largely in the block of ground between the Last Chance and Nellie Bly faults on the southeast slope of Nigger Baby Hill. The group comprises several northwest-trending tunnels, some of which pass under old workings that were originally developed through the Grandview and Cobbler shafts on the nose of the hill. The most extensive tunnels are now 
caved at the portals, but they were mapped while the ground was open during 1930-31. Beginning with the lowest, the 700-foot level (No. 6) starts very close to the old Last Chance portal and runs N. $27^{\circ} \mathrm{W}$. for 310 feet, then turns to N. $38^{\circ} \mathrm{E}$. for an additional 460 feet; the altitude of its portal is about 9,340 feet (pl. $2 B$ ). The portal of the 500 -foot level (No. 5), 290 feet to the northwest, is at an altitude of 9,510 feet and is near or at the later bulldozed mining road that leads from the Mountain Spring and adjacent mines on CHC Hill to the Rico Argentine mill on Silver Creek. The workings of this level are irregular, but a major drift leads northwest to barely intersect the Nellie Bly fault at its end, 1,180 feet from the portal, and a more westerly drift follows the general course of the Yellow Jacket fault (pl. 2B). The 400-foot level (No. 4) has three portals at an altitude of 9,618 feet (pl. $2 A$ ), and has the most extensive workings, irregular in pattern, of any level. A crosscut to the northwest on this level crosses the Nellie Bly fault and extends 260 feet into its hanging wall; other workings of more westerly trend intersect segments of the Yellow Jacket fault in five places, though none of the workings follow the fault for more than 60 feet (pl. 2A). The 300 A level (No.31/2), at an altitude of 9,670 feet, starts just south of the Yellow Jacket fault but swings onto this fault zone a short distance inside the portal and follows the general course of the fault west-northwest for about 880 feet; at 480 feet, a drift on a more northwesterly course extends for 550 feet. Other and smaller workings include the 300-foot level (No. 3) at an altitude of 9,690 feet, the 200-foot (Woods Hole) level at 9,775 feet, and several others (Nos. 2 and 1) that have long been caved. With minor exceptions, only those workings within 200 feet of the Yellow Jacket fault were productive of ore.

Nigger Baby Hill was the site of some of the earliest mines developed in the Rico district, but they were in oxidized ores high on the nose of the hill. The early mine workings are described by Ransome (1901, p. 375-383), but at the time of his report, the small 400 level was in ore "too poor to pay for working," and the portal was caved. Much of the difficulty on these lower levels lay in the refractory nature of the zinc-bearing sulfide ore which at that time was heavily penalized for its zinc content. After perfection of the flotation process for separating zinc and lead sulfides, these complex ores became exploitable. There was a major surge in mining activity on Nigger Baby Hill in the 1920's, particularly in the latter half of the decade, when the Falcon Lead Co. operated the Yellow Jacket group of claims, and presumably the major developments on the No. 4 and No. 5 levels were made at that time.

The Yellow Jacket fault zone was cut in the southwesternmost workings of levels $31 / 2,4$, and 5 . The stratigraphic dip on the north side is $25^{\circ}-40^{\circ}$ NE., but across the fault zone the direction is reversed to southwest and south at $40^{\circ}-65^{\circ}$. In the ground adjacent to the fault, several subsidiary fractures of roughly parallel strike and steep dip were produced, and differential slippage between the strata produced bedding faults. Both types of break were mineralized.

The stratigraphic horizon is near the base of the middle Hermosa. The A bed, 18 feet thick and dipping northeast at $32^{\circ}$, is cut on the No. 6 level at 220 feet after the tunnel bends northeast, but it is too far from the Yellow Jacket fault to have been mineralized on this level. Updip, it passes about through the former portal of the No. 5 level, and, at closer approach to the fault above that level, it was mineralized where broken by a N. $70^{\circ} \mathrm{W}$. fracture about 100 feet on the north side of the Yellow Jacket fault. The resultant ore body was mined in the Koenig stope, which rises to the west diagonally up the dip to the 400 level, above which the ore body was mined in the Beecher stope. The limestone was replaced downdip from the fracture to a maximum distance of 50 feet in the Koenig stope and 45 feet in the Beecher stope. Replacement updip from the fracture was minor. The A bed was also mineralized on the No. 5 level to a minor extent in the Gray Copper stopes which are more than 500 feet from the Yellow Jacket fault and closer to the Nellie Bly fault (pl. $2 B$ ). In these stopes the common sulfides were accompanied by considerable tetrahedrite.

Above the A bed, thin bedding veins in clastic strata a short interval below the $\mathrm{B}$ bed were mined locally on the No. 4 level, but the stopes are small. The B bed, only 3 feet thick, contains a little disseminated mineral but was not stoped on the 400 level, though a little ore was taken from it updip in minor stoping on the short No. 3 level, which is chiefly a drift on this bed. A thin bedding vein at the base of a sandy shale between the B and C beds was stoped somewhat more extensively, over a length of 100 feet and width of 70 feet, above the No. 3 level. The $\mathrm{C}$ bed was cut at four places along the northeast side of the No. 4 level, including the entry from the northeast portal, and in a raise from the No. 5 level. Except for a little thin ore along its base adjacent to a porphyry body, mined in the Herron stope on the No. 4 level, the $\mathrm{C}$ bed has no known mineralization, but it may have contained ore updip and closer to the Yellow Jacket fault in higher workings that have been long caved. 
Strata of the lower Hermosa below the A bed were cut on the north side of the Yellow Jacket fault on the Nos. 5, 4, and 3A levels. Although doubtless lower strata are cut on the No. 5 level, the section here is more broken and complicated by proximity to the fault. The least complicated section was cut on the No. 4 level, and shows a virtually unbroken stratigraphic sequence of 160 feet below the A bed. At 70 feet below the $A$ bed is a $21 / 2$-foot bed of shaly limestone that has been slightly mineralized and that has been prospected for about 40 feet (516 drift) on the 500 level. All other strata are sandstones and shales. Bedding slips in some of these clastic strata have been somewhat mineralized in places but not to economic grade.

A relatively small stratigraphic thickness has been cut on the south side of the Yellow Jacket fault in the short distance between the fault and the porphyry mass that forms the block to the south. The strata have been faulted and steeply tilted away from the main fault zone. Although no definitive limestone is present in this clastic series, the strata are assumed to be middle Hermosa on the premise that the Yellow Jacket fault is of normal character, with downthrow on the south. However, if the displacement on the fault zone should be small, the stratigraphic horizon might still be lower Hermosa on the mine levels, though the steep southward dip makes probable the presence of middle Hermosa at the surface, as depicted on plate 1 .

The fracture zone in clastic strata along the Yellow Jacket fault has been mineralized and was stoped above the No. $31 \frac{1}{2}$ level. Near the portal of this level, a breccia along the fault zone as much as 35 feet wide has some of its fragments replaced by black sphalerite, galena, and pyrite to yield a rather low-grade ore body that was partly stoped. Farther west along the fault, the breccia pinches out but the mineralization was somewhat intensified, and considerable stoping was done above the level within 10-20 feet of the main fault fracture. Still farther west, beyond the 550 -foot drift that diverges to the northwest into the footwall, the south prong of the tunnel follows a nearly vertical vein that gradually diverges on the south side of the fault to an ultimate distance of 40 feet from the fault. This vein was stoped over a width of 10 feet and a length of about 250 feet for a considerable distance above the level. The Woods Hole level, about 105 feet higher than the No. $31 / 2$ level, stoped a vein of parallel strike but generally lower northward dip and located about 100 feet to the south.

Descriptions given by Ransome (1901, p. 375-383) of the ore deposits in the early mine workings indi- cate that most of the deposits at higher levels were probably also veins in clastic strata near the Yellow Jacket or Nellie Bly faults. Some were steep, others were evidently bedding veins dipping northeast at about the angle of stratigraphic dip. As described, some of the veins lay beyond the Nellie Bly fault in upper Hermosa strata.

\section{FALCON MINE}

The Falcon mine workings consist of three tunnels on the nose of Nigger Baby Hill a short distance above the mine road up Silver Creek. The upper tunnel has long been caved, but the middle and lower tunnels were accessible in the 1950's. The middle tunnel, which has the most extensive workings, is at an altitude of 9,250 feet, and the lower tunnel is at 9,175 feet.

The strata cut by the tunnels are predominantly the basal part of the lower Hermosa and top part of the underlying Larsen Quartzite. These beds dip southward at about $30^{\circ}$. The tunnels run north into the hill, starting in the lower Hermosa and crosscutting to its base, within a distance of 100 feet at the middle tunnel. The ore, which is present chiefly in the middle tunnel, is a sulfide replacement body containing pyrite, sphalerite, and some galena and chalcopyrite in dolomitic limestone at the base of the Hermosa. The presence of chlorite and tremolite among the gangue minerals suggests that the deposit is a somewhat higher temperature replacement than the bulk of the ore deposits in the district. Although the ore bed is 7 feet thick, most of the ore is concentrated in the basal 1-3 feet. A northward-dipping sinuous fault of only a few feet of throw, down on the north, traverses the stoped ground at the end of the entry tunnel and may be one of the controls for the ore. The stope length along the bedding strike amounts to only 180 feet, and the stope width, as projected onto a horizontal plane, is somewhat less.

An exploratory drift has been run eastward from the stope for the most part along the top of the Larsen Quartzite, although relations are somewhat complicated by the sinuous fault and by a small dikelike body of porphyry. At 310 feet, this tunnel turns northeast, cuts first across the fault, which has increased in throw, then crosscuts diagonally the basal part of the Hermosa (brought down by the fault) and into the Larsen Quartzite, here dipping $36^{\circ}-49^{\circ} \mathrm{S}$. After traversing 88 feet in this quartzite (cutting down $55 \mathrm{ft}$ stratigraphically below its top), the tunnel crosses what appears to be a fault dipping south-southwest at $75^{\circ}$, and enters a structureless quartzite, believed to be the Uncompahgre Quartzite. 
The fault intersection is $\mathbf{5 2 3}$ feet from the middle tunnel portal in a N. $56^{\circ}$ E. direction and is probably a segment of the Smelter fault. The prospect tunnel ends after penetrating 40 feet of the Precambrian quartzite. Although a little galena, sphalerite, and pyrite show in fractures in this quartzite, the judgment of the miners in stopping further exploration in this direction seems sound.

\section{AZTEC MINE}

The Aztec mine is west of the Dolores River north of Rico, on the north bank of Aztec Gulch. The workings consist of two tunnels, the lower one, at the end of the access road, at an altitude of 9,540 feet and the upper one, at 9,592 feet. The upper tunnel follows very closely the quartz vein on the Nellie Bly fault for a total length of 525 feet, striking $\mathrm{N} .70^{\circ} \mathrm{W}$. The lower tunnel drifts on the vein for 210 feet; at 40 feet from the end of this drift, a crosscut of somewhat sinuous pattern has been extended in a general north-northwesterly direction into the hanging wall of the vein for a distance of about 225 feet.

The wallrocks are sandstones, shales, and minor dolomite and shaly limestone of the lower Hermosa dipping north-northeast at $15^{\circ}$. Dikes and small irregular bodies of igneous rock, present in both walls of the fault, indicate that the original faulting preceded at least some of the igneous activity. The igneous bodies include, on the north side of the fault, a dike of the normal latite porphyry of the district, and, just north of this, a dike of alaskite porphyry about 15 feet thick. Both of these are exposed on the outcrop north of the portals of the tunnels and are also cut in the mine workings. Other dikes and sills of the latite porphyry and less regular small masses of both igneous types are also present on both sides of the fault within the workings.

The quartz vein is 1-6 feet thick in the mine workings. It contains a little pyrite in places, but most of the mineralization in the mine is fine-grained replacement sphalerite and galena of varying richness in the sedimentary rocks immediately bordering the quartz vein. The mine has never been very productive but was one of the earliest worked in the district because of the silver contained in scattered pockets of oxidized material.

\section{NORA LILY MINE}

The Nora Lily mine consists of two tunnels, now caved, driven eastward on the Last Chance fault zone from the west side of Nigger Baby Hill. The lower tunnel, which was the main working level, is at an altitude of 9,072 feet and had an original length of about 700 feet. Only the front 400 feet was accessible in 1931. A crosscut 300 feet from the portal goes north-northeast into the hanging wall for 335 feet. The upper level, at an altitude of 9,120 feet, has a length of about 295 feet virtually parallel to the lower level though offset 7-20 feet north of it, owing to the dip of the vein; an additional 35 feet at the end bears northeast. Any extensions made in the workings during World War II were, at most, negligible.

The portal of the lower tunnel is virtually on the fault contact between Uncompahgre Quartzite on the south and a thick latite porphyry mass on the north. Developments in the mine show that the porphyry mass is a thick sill whose undulatory base is exposed in the crosscut. Both tunnels are driven on a fault vein in the highly altered porphyry, presumably just north of the quartzite contact, though this contact was not cut in the workings. The vein dips southward at $70^{\circ}-85^{\circ}$. On the lower level a second vein of parallel strike, dipping southward at $50^{\circ}-55^{\circ}$, is $5-15$ feet south of the main vein and was intersected in two short crosscuts; a third vein is present locally between the other two. All unite upward into the single vein on the upper level.

The ore consists of sphalerite, pyrite, and galena, irregularly distributed along the veins in thicknesses as great as 2 feet. Some ore has been shipped, but the mine has never been very productive.

\section{PRO PATRIA AND REVENUE MINES}

The Pro Patria and Revenue tunnels are nearly parallel crosscuts that enter the northern part of Newman Hill at altitudes of 9,425 and 9,576 feet, respectively. Their general course is about S. $30^{\circ} \mathrm{E}$. for a quarter of a mile to intersection with the veins, which strike northeast-southwest. In the vein zone there is an upper level, 60 feet above the Revenue level and connected with that level by a steep inclined raise.

The rocks cut in the workings are lower Hermosa, dominantly sandstones and arkoses and subordinately shales, dipping south to southwest at angles of $10^{\circ}-30^{\circ}$. These rocks contain a few sills and dikes of the latite porphyry. A few thin seams of shaly limestone in the sequence have not been especially affected by the mineralization.

Five or six veins have been developed, though unequally, within a vein zone that is about 500 feet wide. At least 900 feet of drifting on one vein at the Revenue level connects at the southwest end with old drifts from the Laura mine which are said to be (label on mine map) on the Enterprise vein. However, Rickard (1897, p. 970) deprecates attempts 
to extend specific veins of Newman Hill indefinitely along the strike because of the tendency for individual veins to die out and be overlapped by others in similar position; neither he nor Ransome (1901, pl. 29) extended the Enterprise vein northeast of the Laura shaft. The veins are on faults of small throw, maximum 17 feet where determinable, striking generally between N. 28 ${ }^{\circ}$ E. and east-west, averaging perhaps N. $45^{\circ}$ E. They are somewhat sinuous between straight stretches and may locally bend through east-west to an east-southeast strike for short stretches. Dips are $65^{\circ}-90^{\circ}$ in either direction. Within these dips, the fault displacements may be normal or reverse.

The veins are broken and slightly offset by numerous small faults of northwest to north strike which dip northeast at $40^{\circ}-70^{\circ}$, rarely to $90^{\circ}$. The offset is generally left lateral, though in part, right lateral. Although a few of these cross faults are weakly mineralized, most contain only gouge, quartz, and a little pyrite. Because these cross faults are down on the northeast, they repeatedly drop updip extensions of the strata, thus tending to repeat, on a given mine level, strata in a relatively small section of the total stratigraphic sequence. The porphyry dikes mostly follow this northwest system of fractures, but the veins continue unbroken across the dikes. Ransome (1901, p. 320-22, 331-34) has discussed the relation between the northeasterly and northwesterly vein system in other parts of Newman Hill, and the relations may be more complex than simple faulting of an earlier by a later system (see p. 76).

The veins in the Pro Patria-Revenue workings are generally only a few inches to a foot thick, rarely lensing to a maximum of 2 feet. They contain pyrite, sphalerite, galena, and a little chalcopyrite with a quartz and commonly also rhodochrosite, rhodonite, and rarely calcite, gangue. Some of the veins are crustified, the rhodochrosite and rhodonite tending to occur along the borders and the quartz in the centers. Scattered small shoots have been found that are rich in silver and free gold, the silver occurring, at least in part, as polybasite.

The mines have been worked intermittently but generally only during periods of high base-metals prices. In the early days of the Rico camp, the same or similar veins were worked, chiefly for silver, farther southwest in Newman Hill where they were far more profitable and where they acted as feeder channels to a blanket replacement deposit of exceptional richness in residual material derived from the leaching of gypsum. The blanket deposits were not found northeast of the Laura shaft and were depleted before 1900. Ransome (1901, p. 308-340) gives a very full account of the ore deposits in that area.

\section{FOREST PAYROLL MINE}

The Forest Payroll mine is at an altitude of 10,137 feet, on the spur leading northwest from Dolores Mountain, high on the left slope of Allyn Gulch. It is reached by a mine road that starts at the south end of Rico, climbs around the south end of Newman Hill, and cuts back northeast as a high-level road across the whole length of Newman Hill. The main working is an entry adit, 400 feet long, going S. $29^{\circ} \mathrm{W}$. into the hill, with cross drifts that follow the intersected veins. Only one vein, 280 feet from the portal, has been developed to any appreciable extent over a length of 480 feet, of which 85 feet is northwest of the entry adit and the rest southeast of it. Another vein near the end of the adit has $\mathbf{8 0}$ feet of drifting on it. Higher levels up raises in the mine were inacessible in 1958.

The rocks cut by the mine workings on the adit level are sandstones, arkoses, and some shales of the lower Hermosa, dipping generally east to southeast at about $10^{\circ}$. Two porhpyry dikes, 12 or 13 feet thick, trending about $\mathrm{N} .70^{\circ} \mathrm{W}$. parallel to the vein system, are intersected at 80 and 150 feet from the portal; another porphyry body of undetermined shape, but probably a dike, is cut for a short distance along the vein walls in the long crossdrift to the southeast.

The ore deposits consists of quartz veins 2 inches to 1 foot, or rarely, to 2 feet thick, containing pyrite, sphalerite, galena, and a little chalcopyrite. Some oxidation has produced considerable limonite, cerussite, and anglesite. The average strike of the vein that has been most developed over a length of 480 feet is $\mathrm{N} .72^{\circ} \mathrm{W}$., and the dip is nearly vertical. However, its strike is somewhat sinuous between straight stretches, and segments vary between $\mathrm{N}$. $65^{\circ} \mathrm{W}$. and east-west. Another vein near the end of the entry adit averages about east-west in the 80 feet developed but swings from N. $83^{\circ} \mathrm{W}$. at its east end to N. $74^{\circ} \mathrm{E}$. at its west end ; its dip is vertical to $80^{\circ} \mathrm{S}$. The veins are developed on faults of small throw; the throw on the main vein is about 8 feet, down on the south.

Some stoping has been done virtually from the surface at a higher level on the property, on an irregular blanket deposit in a thin and presumably limy zone of the lower Hermosa. The ore has here been oxidized to limonite containing cerussite, anglesite, and residuals of galena, with some quartz gangue. 
The Mountain States Mining Co. operated the Forest Payroll mine in the latter half of 1965 and first half of 1966 and shipped 396 tons of ore during this period. The early shipments ( 81 tons) were lead ore, and the later shipments (315 tons) were lead-zinc ore, averaging as follows:

\begin{tabular}{|c|c|c|}
\hline & $\begin{array}{l}\text { Lead ore } \\
\text { (81 tons) }\end{array}$ & $\begin{array}{l}\text { Lead-zinc ore } \\
(315 \text { tons })\end{array}$ \\
\hline Lead _-_._-_Percent _._. & 32.1 & 9.8 \\
\hline - n do - n & 1.2 & \\
\hline $\begin{array}{l}\text { Copper } \\
\text { Arsenic }\end{array}$ & 1.15 & 1.37 \\
\hline Arsenic _- - - do & 0.09 & 0.135 \\
\hline ntimony --o-do do & 0.15 & \\
\hline ver & 19.0 & 5.9 \\
\hline ld & 0.025 & 0.014 \\
\hline
\end{tabular}

IRON CLAD (SILVER CLAD) MINE

The Iron Clad mine, worked for many years by Myron Jones, came under the control of Silver Bell Mines in 1969. The mine is below the Engel's mine road on the west side of the Dolores River southwest of Rico, in the first hundred feet above the valley floor. The workings are two tunnels, which enter the hill in a southwesterly direction. The No. 1 (lower) tunnel is at an approximate altitude of 8,725 feet, and the No. 2 tunnel, whose portal is 175 feet to the southwest, is about 75 feet higher. Most recent development has been in the No. 1 tunnel.

The stratigraphic horizon is in shales, sandstones, arkoses, and some shaly limestones of the lower Hermosa, dipping south at $15^{\circ}$. The sequence is capped by a porphyry sill about 8 feet thick where it is cut near the south end of the upper tunnel workings. This sill forms the back at the south end of the lower tunnel and in stopes above this tunnel. The known mineralization is below the sill and comprises veins on fractures of small (0-4 ft) displacement and replacement bodies in shaly limestone and limy shale within a few feet of the feeding veins. The veins trend northeastward: the two major ones, 75-140 feet apart on the lower level, trend between N. $20^{\circ}$ E. and N. $45^{\circ}$ E., and a third vein, on which the lower tunnel enters the hill, trends N. $65^{\circ} \mathrm{E}$. over much of its course. Dip is to the northwest at $50^{\circ}-80^{\circ}$. The northwest vein has been stoped on both tunnel levels. Vein thickness is generally 1-12 inches, but may be as thick as 2 feet, particularly in the sandstones and arkoses where the veins also have a tendency to horsetail. Replacement bodies in more limy strata centered on the veins are 2-15 feet wide and as much as 10 feet thick.

The ore consists of massive sphalerite, galena, pyrite, and chalcopyrite. It contains a few ounces of silver per ton of ore, the veins in the coarse arkose being somewhat richer than those in the more shaly wallrocks. At least part of the silver is in the silver minerals polybasite, pyrargyrite (ruby silver), and argyrodite. Gangue minerals include quartz, which is especially conspicuous in the replacement ore bodies, and a little calcite.

The mine has not been very productive in the past from lack of small-scale milling facilities. In 1969 the ore was trucked to the Silver Bell mill at Ophir for milling. As the developed horizon is in the lower Hermosa, presumably not far above the LeadvilleOuray Limestones, the management was particularly interested in testing this lower ore horizon by drilling. According to newspaper accounts (Dolores [Colorado] Star, Nov. 28, 1969), the Silver Bell Mines Co. initiated such a drilling program in the fall of 1969 and intercepted lead-zinc ore in the limestone at a depth of $625-675$ feet.

JONES GOLD MINE

The Jones gold mine has developed a unique type of mineral deposit in the Rico district in that the total values are in free gold. The deposit has not been very productive because the pockets containing the gold have been scattered, and considerable development work is necessary between pockets. However, the pockets, when found, are rich enough to encourage further search.

The tunnel is on the west side of the Dolores River southwest of Rico, just above the Engel's mine road, at an approximate altitude of 8,845 feet. The property is known as the St. Louis claim, which is not to be confused with the many other properties in the district worked in the 1920's and 1930's by the St. Louis Smelting \& Refining Co. The tunnel enters the hill in a westerly direction, and after 160 feet, bends southwest for an additional 335 feet. It is driven in sandstones and shales of the lower Hermosa which dip about $10^{\circ}$ between southwest and south. A porphyry sill exposed in the mine may be the same sill as in the Iron Clad workings to the southeast.

The gold occurs (1) chiefly in a thin shale breccia just above a bedding fault about 15 feet above the porphyry sill; (2) in fractures of no perceptible displacement which sole on the breccia; and (3) in a bedding seam, ranking second in richness, at the top of the fractures and about 30 feet above the shale breccia. The following section gives the stratigraphic setting:

Top Thickness
(feet) Bedding seam, second richest ore horizon -.....- $1 \pm$ Dark shale and sandy shale, containing veins _..- $30 \pm$ Shale breccia, finely fragmented; major ore carrier 1-2 Clay gouge Dolomite, light-gray, hard, tough, finely pyritic -.- 1 Black shale, barren Porphyry sill in which feldspar phenocrysts are kaolinized 14 
The veins are very irregular but, on the average, dip northwest at about $60^{\circ}$. Any gold is concentrated on their footwalls.

The gold is free and generally associated with a little pyrite which, however, carries only 0.02 ounce gold per ton. Calcite and a little loose quartz are also commonly present, but, in much of the ore, the free gold has no gangue.

\section{ATLANTIC CABLE Mine}

The Atlantic Cable mine is in the town of Rico, just west of the main street and just north of Silver Creek. It is entered through a shaft that was sunk before 1900. During World War II the shaft was pumped out by the Rico Argentine Mining Co., and some zinc-lead-copper ore was produced. The following account is largely abstracted from Ransome (1901) and Varnes (1944).

The mine has three levels, at 45, 62, and 183 feet below the surface. The two upper levels are in marbleized limestone of the Leadville or Ouray Limestones which dip south to southeast at about $25^{\circ}$. The shaft was sunk in a high-grade ore body consisting of lead, zinc, iron, and copper sulfides and specular hematite. The main sulfide ore body occupies a generally central position within a larger mass of specularite, magnetite, and chlorite, following a general northwest fracture zone marked by quartz stringers. The iron oxide body has been developed over a length of about 400 feet and is mostly 40-60 feet wide, but widens at both ends, to 150 feet at the southeast end. The richer bodies of sulfide ore within this iron oxide mass have been stoped, but pods and irregular masses of pyrite, sphalerite, galena, and chalcopyrite occur scattered through the mass of "black iron" beyond the confines of the main sulfide mass. At many places a band of lead and zinc sulfides 1 inch to 1 foot thick lies at the contact between the iron oxides and the enclosing marble. The mineralization is typical of contact-metamorphic ore deposits.

\section{SUGGESTIONS FOR PROSPECTING}

In massive sulfide replacement bodies in middle Hermosa limestones, the lead-zinc-silver ore shows a pronounced tendency to be confined to the outer edges of the pyrite cores. As the pyritized areas are, in general, larger than their lead-zinc rims, these spatial relations suggest that, if massive pyrite is intersected by a drill hole or mine working, a narrow but potentially rich target for further prospecting is the contact of this pyrite with the surrounding limestone. Although not enough ore bodies have been studied to demonstrate these same spatial rela- tions in places where the Leadville-Ouray Limestones are ore bearing, presumably the same pattern of ore distribution could hold.

The future of the district is believed to lie mainly in the possibility of limestone replacement deposits at two general stratigraphic levels--the limestones of the middle Hermosa and those of the LeadvilleOuray. The former contributed most of the basemetal ores of the past and are currently being exploited, whereas the latter are still largely unexplored. Favorable loci for mineralization are along intersections with the Blackhawk and closely related faults or with such porphyry dikes as the Rico Argentine dike.

The middle Hermosa limestones near their intersections with the Blackhawk fault have been well explored in the footwall of the Princeton fault in CHC Hill. The conclusion of the Rico Argentine Mining Co. that this ground is virtually exhausted and their decision to abandon the area seem justified.

Current mining by the Rico Argentine Mining Co. is in the middle Hermosa limestones along the Blackhawk fault in the hanging wall of the Princeton fault. However, not all the limestone beds are mineralized. Their sequence as given in the generalized section (p. 24) and their geometry in space, as depicted on plate 3 , should aid in more clearly defining targets for exploration. Because the A bed has been cut in so few places in the Rico Argentine mine, little is known of its thickness and susceptibility to mineralization in this mine. If it should prove to be a worthwhile target, there is a large block of ground between the Blackhawk and 210 Drift faults in which the intersection of the A bed with the Blackhawk fault or the Rico Argentine dike would be accessible from the 300 and lower levels. North of the 210 Drift fault, all the limestone beds below the $\mathrm{E}$ bed would appear to be acceptable targets at their intersections with the Blackhawk fault, though exploration of the D, C, and $\mathrm{B}$ beds on the 500 level (pl. $3 G$ ) has been fruitless. The intersection of the middle Hermosa with the Blackhawk fault plunges northward from the block of ground in which the mining company is currently working, and all limestone beds should be considered potential loci for ore shoots down to the intersection with the Princeton fault.

The limestone of the Leadville-Ouray sequence has yielded ore in the structurally high area in and immediately adjacent to the townsite of Rico. Because it is here close to the surface, it has been accessible to shallow exploration. Elsewhere, it can be reached only by moderate to deep drilling at 
greater expense and with attendant disadvantages in the delineation of targets. Obviously, favorable areas would be where the Leadville-Ouray Limestones underlie known mineralization at higher levels.

One of the most obvious of promising areas is in the general vicinity of the Iron Clad mine, where base-metal veins containing silver minerals have been worked in the lower Hermosa. Initial drilling was done here by the Silver Bell Mines Co. in the fall of 1969, and newspaper accounts (see p. 94) indicate that mineralized ground, presumably in the Leadville-Ouray, was struck at a depth of 625-675 feet. Prospect workings higher up the hill within a quarter of a mile west of the Iron Clad tunnels reveal base-metal mineralization in the lower Hermosa that would indicate equally favorable targets in the underlying limestone, but exploration from the pertinent sites would require an additional depth of drilling or sinking to the target ground.

Another area that would normally invite attention is the fractured zone that contains the veins formerly worked for silver in Newman Hill. However, intervention of the thick porphyry sill between the vein-bearing ground and the Leadville-Ouray Limestones makes the depth to the limestones about 1,000 feet, even when holes are drilled from inside the long Lexington tunnel. Two such holes (1 and 2) drilled by the Pelleyre Mining Co. in the vicinity of the Jumbo shaft are reported to have contained a little pyrite, galena, sphalerite, and specularite in the limestone interval, but no significant mineralization. The other two Pelleyre holes (3 and 5) in Newman Hill were outside the richly mineralized area; one of these (3) contained a little specularite and base-metal sulfides, including chalcopyrite, in the Leadville-Ouray, but no ore.

The attempt by the St. Louis Smelting \& Refining Co. to explore, from the St. Louis tunnel, the deep limestone adjacent to the Blackhawk vein ended in failure to reach the Leadville-Ouray. Nevertheless, the concept on which the exploration was based has merit. The failure may have been partly due to the error in the estimated thickness of the lower Hermosa. If the surmise is correct that the porphyry intercepted at 630-742 in drill hole 3 is at approximately the same horizon as the Newman Hill sill (see p. 81), the Leadville-Ouray should be reached at an approximate depth of 1,000 feet on the hanging-wall side of the vein, and at about 950 feet on the foot-wall side; this conclusion is based on the assumption that the major fault displacement along the St. Louis tunnel is on the alaskite porphyry dike (see p. 81).
The Leadville-Ouray Limestones should be accessible to exploration in the footwall of the Blackhawk fault in the deeper workings of the Rico Argentine mine. On the 300 level, the southernmost working enters the Blackhawk fault zone, though it may not have completely penetrated this zone. From the end of this working, diamond-drill hole 364 extends 89 feet nearly horizontally into the footwall of the fault (pl. $3 E)$. The core between 46 and 89 feet was logged by the company geologist as "schist or quartzite." A sample of this core shown to the author was a highly pyritic quartzite. If this core represents the Uncompahgre Quartzite rather than a locally quartzitized phase of the lower Hermosa, the horizon of the Leadville-Ouray must be in the footwall of the fault somewhere between the Blaine and 300 levels. A logical place to test this surmise would be near the end of the 208 drift on the 200 level (pl. 3D).

The large variation in thickness of the LeadvilleOuray Limestones over a relatively small area suggests some caution in prospecting this unit. In a structurally complex, but generally positive, area along the Rico dome, the ground may have been structurally active at different periods in the geologic past, including the time preceding deposition of the Larsen Quartzite. Indeed, this quartzite may be the record of very abrupt uplift and local erosion that cut as deep as the Precambrian. Under such conditions, the Leadville-Ouray could be entirely absent in places. Subsurface exploration of one form or another will be necessary to define the existence. thickness, and mineral potential of the formation.

\section{REFERENCES CITED}

Armstrong, R. L., 1969, K-Ar dating of laccolithic centers of the Colorado Plateau and vicinity: Geol. Soc. America Bull., v. 80 , no. 10 , p. $2081-2086$.

Atwood, W. W., and Mather, K. F., 1932, Physiography and Quaternary geology of the San Juan Mountains, Colorado: U.S. Geol. Survey Prof. Paper 166, 176 p.

Bastin, E. S., 1922, Silver enrichment in the San Juan Mountains, Colorado: U.S. Geol. Survey Bull. 735-D, p. 65-129.

Battey, M. H., 1955, Alkali metasomatism and the petrology of some keratophyres: Geol. Mag., v. 92, no. 2, p. 104126.

Bromfield, C. S., 1967, Geology of the Mount Wilson quadrangle, western San Juan Mountains, Colorado: U.S. Geol. Survey Bull. 1227, 100 p.

Burbank, W. S., 1940, Structural control of ore deposition in the Uncompahgre district, Ouray County, Colorado: U.S. Geol. Survey Bull. 906-E, p. 189-265.

Burbank, W. S., and Luedke, R. G., 1964, Geology of the Ironton quadrangle, Colorado: U.S. Geol. Survey Geol. Quad. Map GQ-291.

Cross, Whitman, and Hole, A. D., 1910, Description of the 
Engineer Mountain quadrangle [Colorado]: U.S. Geol. Survey Geol. Atlas, Folio 171, 14 p.

Cross, Whitman, Howe, Ernest, and Irving, J. D., 1907, Description of the Ouray quadrangle [Colorado]: U.S. Geol. Survey Geol. Atlas, Folio 153, 20 p.

Cross, Whitman, Howe, Ernest, Irving, J. D., and Emmons, W. H., 1905, Description of the Needle Mountains quadrangle [Colorado]: U.S. Geol. Survey Geol. Atlas, Folio $131,14 \mathrm{p}$.

Cross, Whitman, Howe, Ernest, and Ransome, F. L., 1905 Description of the Silverton quadrangle [Colorado]: U.S. Geol. Survey Geol. Atlas, Folio 120, 34 p.

Cross, Whitman, and Purington, C. W., 1899, Description of the Telluride quadrangle [Colorado]: U.S. Geol. Survey Geol. Atlas, Folio 57, 19 p.

Cross, Whitman, and Ransome, F. L., 1905, Description of the Rico quadrangle [Colorado]: U.S. Geol. Survey Geol. Atlas, Folio 130, 20 p.

Cross, Whitman, and Spencer, A. C., 1900, Geology of the Rico Mountains, Colo.: U.S. Geol. Survey, 21st Ann. Rept., pt. 2, p. 7-165.

Daly, R. A., 1933, Igneous rocks and the depths of the earth: New York, McGraw-Hill Book Co., 508 p.

Deer, W. A., Howie, R. A., and Zussman, J., 1962-1963, Rock-forming minerals: New Y̌ork, John Wiley \& Sons, $5 \mathrm{v}$.

Edwards, A. B., 1954, Textures of the ore minerals and their significance [2d ed.]: Melbourne, Australasian Inst. Mining Metallurgy, $242 \mathrm{p}$.

Farish, J. B., 1892, On the ore deposits of Newman Hill, near Rico, Colorado: Colorado Sci. Soc. Proc., v. 4, p. 151-164.

Gilluly, James, 1933, Replacement origin of the albite granite near Sparta, Oregon: U.S. Geol. Survey Prof. Paper 175-F, p. 65-81.

- 1935, Keratophyres of eastern Oregon and the spilite problem: Am. Jour. Sci., 5th ser., v. 29, p. 225-252, 336-352.

Glass, J. J., Jahns, R. H., and Stevens, R. E., 1944, Helvite and danalite from New Mexico, and the helvite group: Am. Mineralogist, v. 29, nos. 5-6, p. 163-191.

Goldschmidt, Victor, 1913-23, Atlas der Krystallformen: Heidelberg, C. Winter, 9 v.

Heidorn, F., 1932, Über ein Vorkommen von Sellaite $\left(\mathrm{MgF}_{2}\right)$ in Paragenese mit Bitumen aus dem Hauptdolomit des mittleren Zechsteins bei Bleicherode: Centralbl. Mineralogie, Geologie u. Paläontologie, Abt. A, p. 356-364.

Henbest, L. G., 1948, New evidence on the age of the Rico Formation in Colorado and Utah [abs.]: Geol. Soc. America Bull., v. 59, no. 12, pt. 2, p. 1329-1330.

Henderson, C. W., 1926, Mining in Colorado: U.S. Geol. Survey Prof. Paper 138, 263 p.
Johannsen, Albert, 1932, A descriptive petrography of the igneous rocks; V. 2, The quartz-bearing rocks: Chicago, Univ. Chicago Press, 428 p.

1937, A descriptive petrography of the igneous rocks; V. 3, The intermediate rocks: Chicago, Univ. Chicago Press, $360 \mathrm{p}$.

Larsen, E. S., Jr., and Cross, Whitman, 1956, Geology and petrology of the San Juan region, southwestern Colorado: U.S. Geol. Survey Prof. Paper 258, 303 p.

Lewis, G. E., and Vaughn, P. P., 1965, Early Permian vertebrates from the Cutler Formation of the Placerville area, Colorado: U.S. Geol. Survey Prof. Paper 503-C, $50 \mathrm{p}$.

Luedke, R. G., and Burbank, W. S., 1962, Geology of the Ouray quadrangle, Colorado: U.S. Geol. Survey Geol. Quad. Map GQ-152.

Nockolds, S. R., 1954, Average chemical compositions of some igneous rocks: Geol. Soc. America Bull., v. 65, no. 10, p. 1007-1032.

Palache, Charles, Berman, Harry, and Frondel. Clifford, 1951, The system of mineralogy, V. 2 [7th ed., rev.]: New York, John Wiley \& Sons, 1124 p.

Pratt, W. P., McKnight, E. T., and DeHon, R. A., 1969, Geologic map of the Rico quadrangle, Dolores and Montezuma Counties, Colorado: U.S. Geol. Survey Geol. Quad. Map GQ-797.

Ransome, F. L., 1901, The ore deposits of the Rico Mountains, Colorado: U.S. Geol. Survey 22d Ann. Rept., pt. 2, p. 229-398.

Rickard, T. A., 1897, The Enterprise mine, Rico, Colorado: Am. Inst. Mining Engineers Trans., v. 26, p. 906-980.

Spurr, J. E., 1900, Classification of igneous rocks according to composition: Am. Geologist, v. 25, p. 210-234.

Terzaghi, R. D., 1948, Potash-rich rocks of the Esterel, France: Am. Mineralogist, v. 33, no. 1-2, p. 18-30.

Turner, F. J., and Verhoogen, John, 1960, Igneous and metamorphic petrology [2d ed.]: New York, McGraw Hill Book Co., 694 p.

Tyler, S. A., and Marsden, R. W., 1938, The nature of leucoxene: Jour. Sed. Petrology, v. 8, no. 2, p. 55-58.

Varnes, D. J., 1944, Preliminary report on the geology of a part of the Rico dome, Dolores County, Colorado: U.S. Geol. Survey open-file map.

Vaughn, P. P., 1962, Veterbrates from the Halgaito Tongue of the Cutler Formation, Permian of San Juan County, Utah: Jour. Paleontology, v. 36, no. 3, p. 529-539.

Vhay, J. S., 1962, Geology and mineral deposits of the area south of Telluride, Colorado: U.S. Geol. Survey Bull. 1112-G, p. 209-310.

Winchell, Horace, 1958, The composition and physical properties of garnet: Am. Mineralogist, v. 43, nos. 5-6, p. 595-600. 


\section{INDEX}

[Italic page numbers indicate major references]

A

Page

Acknowledgments

Actinolite

Adularia

Ahkeah tunnel

Alabandite

Alaskite fault

Alaskite porphyry -..--

Albite

Allanite

Alluvium

nalyses, chemical _..._. $33,62,63$

electron probe

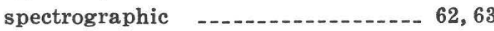

X-ray powder _................. 38

Andalusite

Anglesite

Apatite

Aragonite

Argentine shaft

Argentine tunne

Argentite

Argyrodite

Atlantic Cable mine -..._._._._._... 11, 12, 95

Aztec Gulch

Aztec mine

38,92

B

Barite

Base-metal prices

Biotite

Black Wonder tunnel _................ 13

Blackhawk fault ................ 31, 43, 51

Blackhawk Peak 2

Blacksmith tunnel

Blaine tunnel

Calcareous tufa

Calcite

Carbon dioxide

Cerussite

Chalcopyrite

CHC Hill

Chlorite

Clinozoisite

Cobbler shaft

Contact-metamorphic ore deposits $-75,77$

Copper, production _._._._._. 4, 5

Cordierite -.... 70

Cosalite

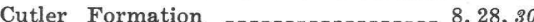

D

Deadwood Gulch _.......... 16

Deposits, blanket, discovery _........ 4

Devonian limestone _....... 5, 7

Devonian System -.................. 11

Diaspore

\section{[Ttalic page numbers indicate major references]}

Diopside

Dolomite

Dolores Mountain

Dolores River

Drainage, mine -0

Duinage, mine - -

Duncan, Helen, cited _..._-_._-_...- 12,

E

Edwards tunnel -

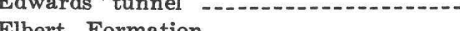

Elliott Mountain -

Engineer Mountain quadrangle

Enterprise blanket deposits -.........

Enterprise claim

Enterprise Group tunnel

Enterprise vein

Epidote

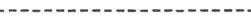

untain - -

Extent, igneous metamorphism

\section{F}

Falcon Lead Co

Falcon mine

-

Falcon tunnel -...................

Falcon working

Fans

Faults

Deadwood Gulch

Delores Mountain and vicinity -..-Fie'dwork

500 level, Rico Argentine mines

Flotation mill, at Rico

Fluorite

Forest Payroll mine

Fossils, Cutler Formation -

Hermosa Formati

Larsen quartzite -.............. 15

Leadville Limestone -......

400 level, Rico Argentine mines _.....- 88

Futurity fault

Futurity mine

G

Galena

Gangue minerals

Garnet

Geography

Gold, native -

production

Grandview mine

Grandview shaft

Gravel

Gray Copper stopes

Greenstone, Precambrian

Gypsum

H

Harts Peak

Hedenbergite

Helvite
Hematite

58

Hermosa Formation -

Hidden fault -...... 55

History, Rico district _.......... 4

Holocene Series -...-

Honduras fault -

Hornblende - - 68

Horst, Dolores Valley -_._- 43, 44

Huebnerite

65

Ignacio Quartzite

$7,10,15$

Igneous intrusion, age

Igneous metamorphism

Igneous rocks

relations between different types -- 41

Iron Clad mine -

Iron oxides

Ironton quadrangle

International Smelting Co

Introduction

J

James G. Blaine tunnel

$\begin{array}{ll}\text { Jones gold mine } & 62 \\ & \end{array}$

$\mathbf{K}$

Kaolinite

Knob Hill fault

Koenig stope

fault -

L

Lamprophyre, hornblende

Landslide deposits

Larsen tunnel

Larsen Quartzite

Last Chance fault

Last Chance tunne

Laura mine

Lead, production $\quad 92$

Leadville Limestone _. $8,11,13,15,16,28,80$

Lexington tunnel _...................... 12, 15

Limonite

Log Cabin (Blackhawk) tunnel

M

Magnetite

Malachite

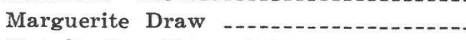

Metadiorite, Precambrian

Metamorphic minerals -............

Mineralogy, igneous metamorphism -.. ore deposits -...

Minerals, hypogene

Mines

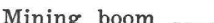

Mississippian limestone

Mississippian System

Molas Formation 


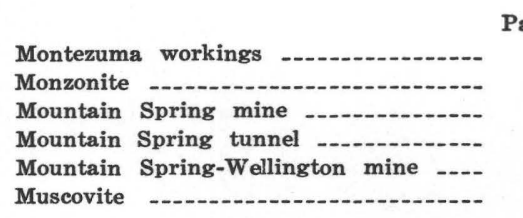

$\mathbf{N}$

Needle Mountains quadrangle -...-. 10,11 Nellie Bly fault

New Year (Golden Fleece) tunnel -. 12

Newman Hill

Nigger Baby Hill

Nora Lily mine

Ore deposits

$4,57,73$

Ore veins

Ouray Limestone $7,8,10,11,16,80$

\section{$\mathbf{P}$}

Paleozoic hiatus -

Paragenesis

Pearceite -

Pebble dikes 61

Pelleyre Mining \& Milling

Pennsylvanian System -

Permian System - 30

Phlogopite

Polybasite

Porphyry, alaskite hornblende latit

Potassium feldspar

Precambrian rocks

Prehnite

Previous literature

Princeton fault $31,43,50$

Pro Patria mine -

Production -.-. 5

Prospecting suggestions - -

Proustite -

Pyrargs

Pyrite

Pyrolusite

Pyrrhotite

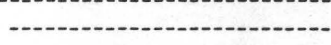

$\mathbf{Q}$

Quartz

Quaternary System
$\mathbf{R}$

Page

4,5

Railroads

Ransome, F. L., cited - 46

Replacement deposits _-........... 73, 77

Revenue mine -....... 5, 92

Rhodochrosite -

Rhodonite

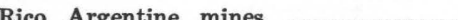

Rico Argentine Mining Co

Rico Consolidated tunnels -...-.....

Rico Enterprise Mining Co -........

Rico Formation

Rico Mining \& Reduction Co -...-..-

Rico Mountains

Rico-Wellington Mining Co -.......

Rio Grande Southern Railroad Co ---

Riverside claim

Ruby silver

Rutile

\section{$\mathbf{S}$}

St. Louis adit

St. Louis Smelting \& Refining Co

St. Louis tunnel

San Juan Mountains

Sandstone Mountain

Sandstone Mountain fault

Sellaite

Sericite

Serpentine

Serpierite

Shamrock claim

Siderite, manganoan

Silver Creek

Silver Creek fault

Silver Creek mine

Silver ores, discovery

Silver production

Silver Swan mine

Silverton quadrangle

(evel, Rico Argentine mines

Slope wash

Smelter fault

Sme!ters, at Rico

Smithsonite

Smuggler claim

South Park fault

Spalerite

Sphene

Stephanite

Stewart, D. B.
Stratigraphic section, Hermosa

formation $16,17,18$

Jones gold mine

Larsen Quartzite

Rico Formation

Sandstone Mountain

Stratigraphy

Structure

relation to intrusion rocks

Supergene minerals

Surficial deposits

Sulfide replacement deposits

- - - - - - -

Sufides

Sulfuric acid plant

Talus

Telescope Mountain

Tennantite

Tetradymite -

Tetrahedrite -................

300 level, Rico Argentine mines -...-

Timberline

Topaz

Transportatio

Tremolite

200 level, Rico Argentine mines $-{ }^{-}$

210 Drift fault

(n)

$\begin{array}{rr} & 4 \\ - & 94 \\ - & 14 \\ - & 29 \\ - & 3 \\ - & 8 \\ - & 43 \\ - & 56 \\ - & 71 \\ - & 31 \\ - & 73 \\ - & 58 \\ - & 4,5\end{array}$

Union Carbonate mine -..--

Union Carbonate Mines, Inc. -...... 5

Uncompahgre Quartzite -..... 10,14, 15, 16

$$
\text { V }
$$

Van Winkle shaft

w

Wellington mine -

Wellington tunnel

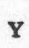

Yellow Jacket fault

Yellow Jacket mine

$\mathbf{Y}$

78

Zinc, production

4, 5 